Prepared in cooperation with the Bureau of Land Management, National Park Service, U.S. Department of Energy National Nuclear Security Administration (Interagency Agreement DE-AI52-01NV13944), and Office of Civilian Radioactive Waste Management (Interagency Agreement DE-AI28-02RW12167), U.S. Fish and Wildlife Service, and Nye County, Nevada

\title{
An Update of the Death Valley Regional Groundwater Flow System Transient Model, Nevada and California
}

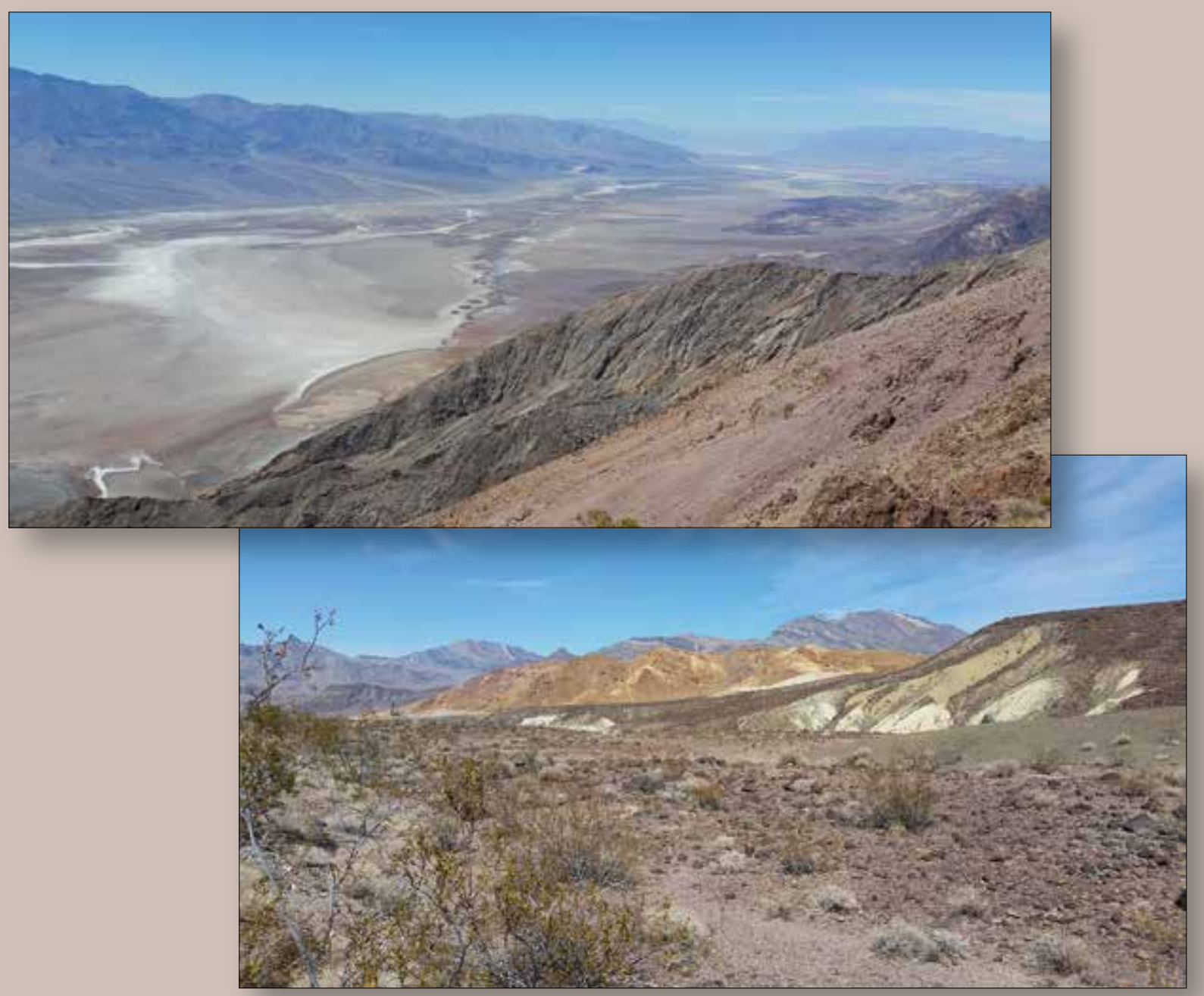

Scientific Investigations Report 2016-5150 
Cover photographs: Top photograph taken from Dante's View in Death Valley National Park, looking toward the north into Badwater basin in Death Valley. Bottom photograph also taken in Death Valley National Park, is of Furnace Creek Wash looking toward the northeast.

The southern Funeral Range is in the background. Both photographs by Wayne Belcher, U.S. Geological Survey, September 21, 2015. 


\section{An Update of the Death Valley Regional Groundwater Flow System Transient Model, Nevada and California}

By Wayne R. Belcher, Donald S. Sweetkind, Claudia C. Faunt, Michael T. Pavelko, and Mary C. Hill

Prepared in cooperation with the Bureau of Land Management, National Park Service, U.S. Department of Energy National Nuclear Security Administration (Interagency Agreement DE-AI52-01NV13944), and Office of Civilian Radioactive Waste Management (Interagency Agreement DE-AI28-02RW12167), U.S. Fish and Wildlife Service, and Nye County, Nevada

Scientific Investigations Report 2016-5150 


\section{U.S. Department of the Interior SALLY JEWELL, Secretary}

\section{U.S. Geological Survey Suzette M. Kimball, Director}

\section{U.S. Geological Survey, Reston, Virginia: 2017}

For more information on the USGS - the Federal source for science about the Earth, its natural and living resources, natural hazards, and the environment-visit http://www.usgs.gov or call 1-888-ASK-USGS.

For an overview of USGS information products, including maps, imagery, and publications, visit http://store.usgs.gov/.

Any use of trade, firm, or product names is for descriptive purposes only and does not imply endorsement by the U.S. Government.

Although this information product, for the most part, is in the public domain, it also may contain copyrighted materials as noted in the text. Permission to reproduce copyrighted items must be secured from the copyright owner.

Suggested citation:

Belcher, W.R., Sweetkind, D.S., Faunt, C.C., Pavelko, M.T., and Hill, M.C., 2017, An update of the Death Valley regional groundwater flow system transient model, Nevada and California: U.S. Geological Survey Scientific Investigations Report 2016-5150, 74 p., 1 pl. https://doi.org/10.3133/sir20165150

ISSN 2328-0328 (online) 


\section{Contents}

Abstract

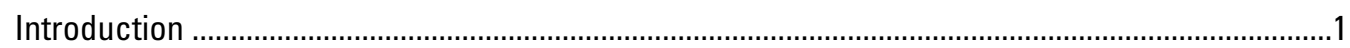

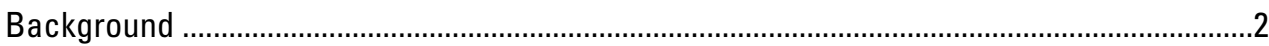

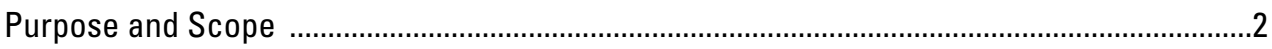

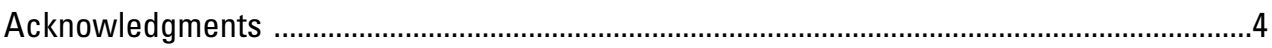

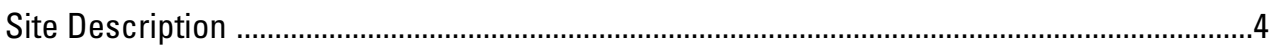

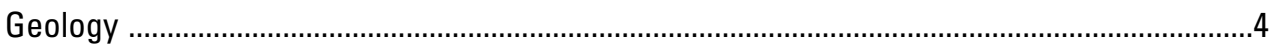

Overview of the Groundwater Flow System ....................................................................

Hydrogeologic Framework Model and Structure Revisions .........................................................

Review of Existing Hydrogeologic Framework Model .......................................................

Revision of the Regional Hydrogeologic Framework Model in the Vicinity of Yucca Flat .....10

Representation of Lithologic and Textural Variations in the Amargosa Desert .....................12

Revisions to Fault Representations in the Hydrogeologic Framework Model and

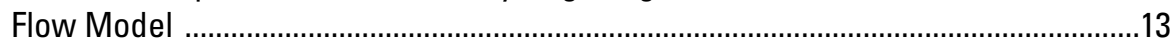

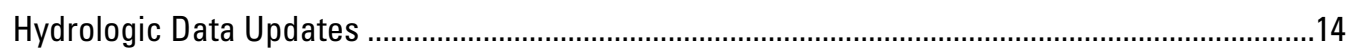

Pumping and Irrigation Return Flows ..........................................................................14

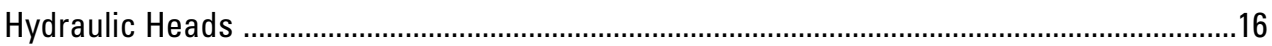

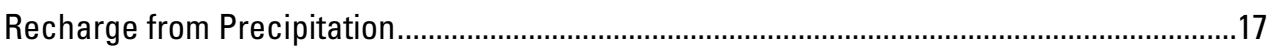

Modification of the Estimated Regional Potentiometric Surface .........................................17

Numerical Model Construction and Revisions ..............................................................................

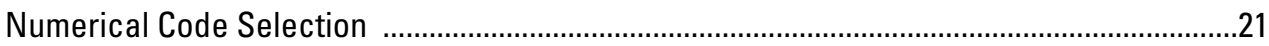

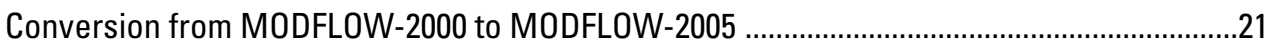

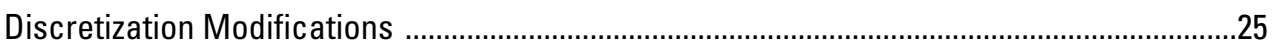

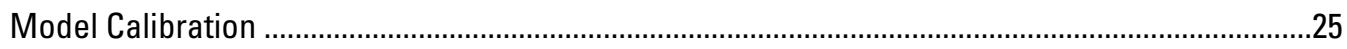

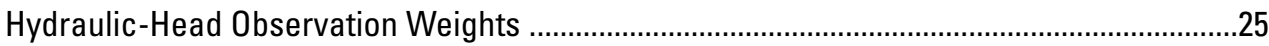

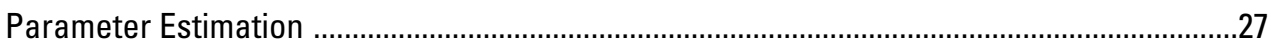

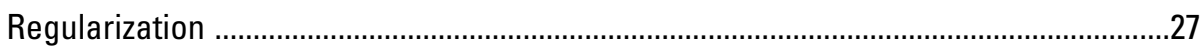

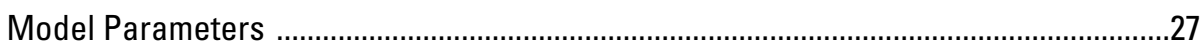

Observations/Prior-Information and Weighting ..........................................................32

Hydraulic Head, Hydraulic-Head Change, and Vertical Hydraulic-Head Gradient ......................................................................................................

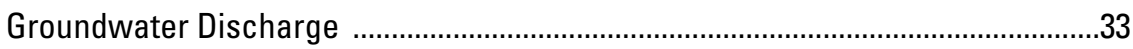

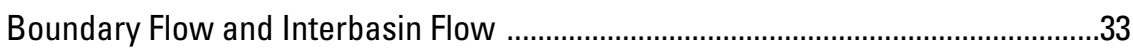

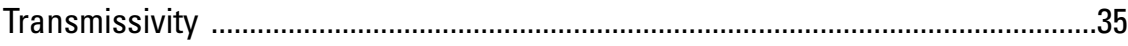

Modification of Observation/Prior-Information Weights .........................................39

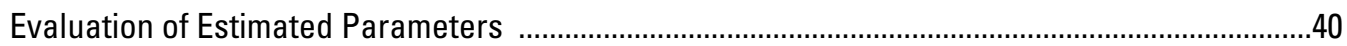

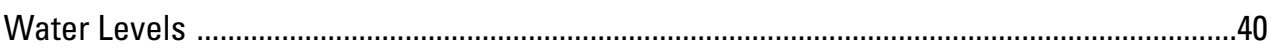

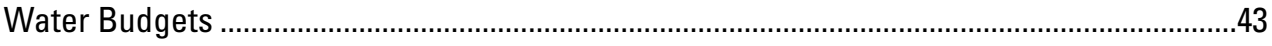

Spring Discharge and Evapotranspiration ......................................................................

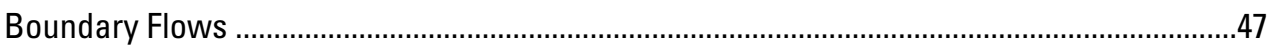

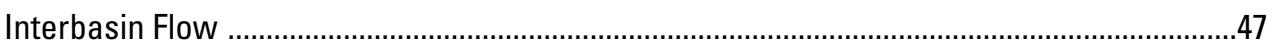

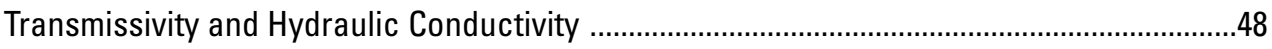

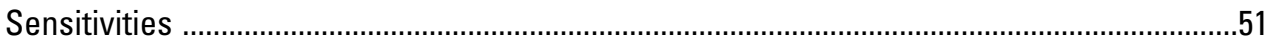


Parameter Correlation ......................................................................................................

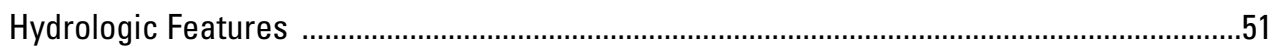

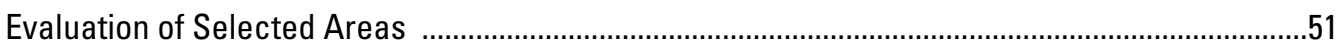

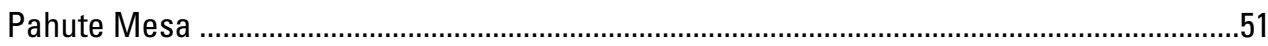

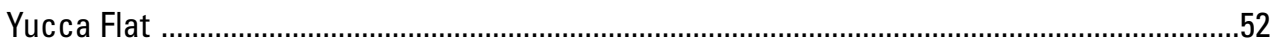

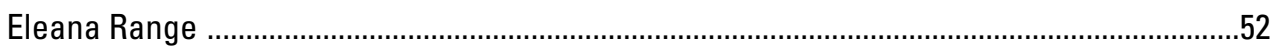

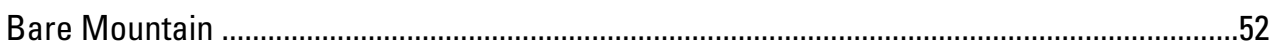

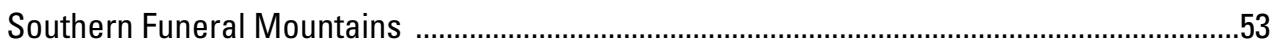

Southern Pahrump Valley ..............................................................................................

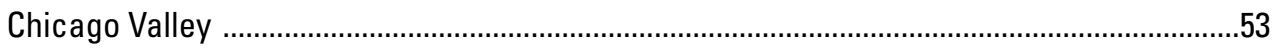

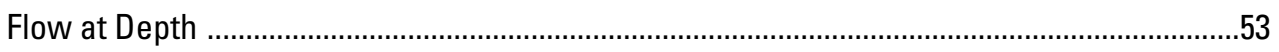

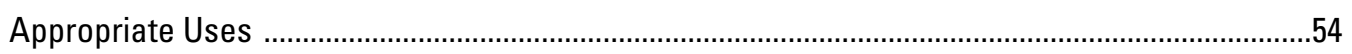

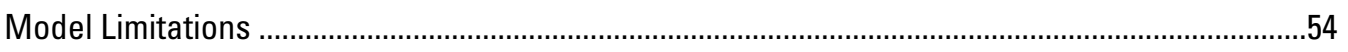

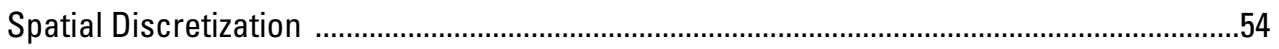

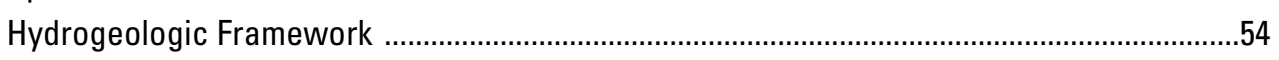

Simulation as a Confined System .................................................................................54

Use of Idealized Potentiometric Surface as Top of Model ...................................................55

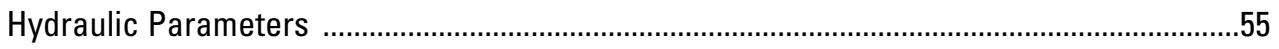

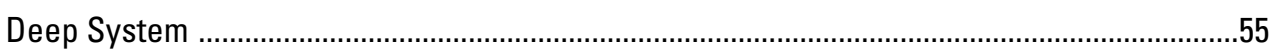

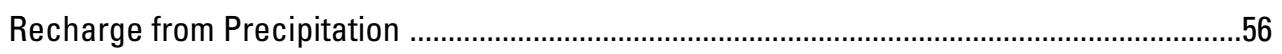

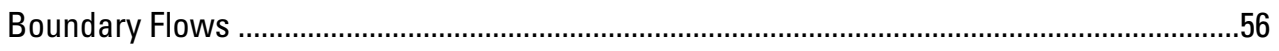

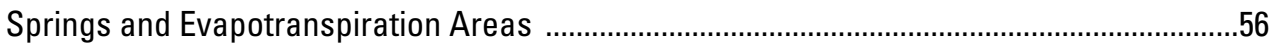

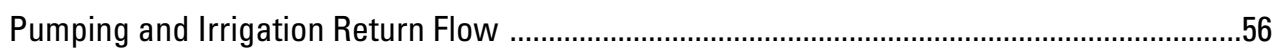

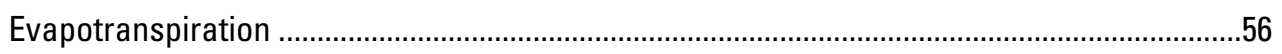

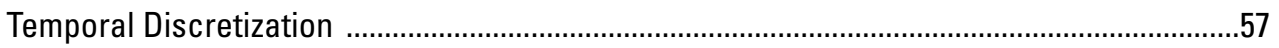

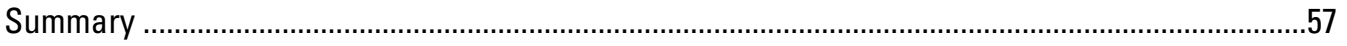

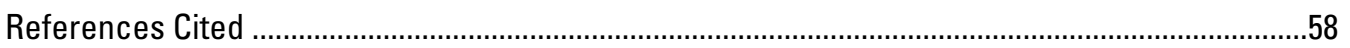

Appendix 1. Simulated parameter values and pilot points estimated in DVRFS v. 2.0 ...................64

Appendix 2. Transmissivity prior-information used in DVRFS v. 2.0 and simulated results ............72

Appendix 3. Instructions for converting a HUF-based model to a BCF-based model ......................74

\section{Figures}

1. Map showing geographic and prominent topographic features in the Death Valley regional groundwater flow system area, Nevada and California

2. Schematic block diagram of the Great Basin illustrating the relations between mountain blocks, intermontane basins, and groundwater flow

3. Map showing subregions, Amargosa River drainage, and fault, shear, and structural zones in the Death Valley regional groundwater flow system area

4. Map showing revisions of the hydrogeologic framework model in the vicinity of Yucca Flat

5. Map showing location of hydrogeologic structures acting as horizontal-flow barriers in the Death Valley regional groundwater flow system v. 2.0 model

6. Graph showing annual estimates of groundwater withdrawal from the Death Valley regional groundwater flow system by general water-use type, 1913-2003, and used in the v. 2.0 model. 
7. Map showing areal distribution of wells included in the original and updated waterlevel databases for the Death Valley regional groundwater flow system, Nevada and California

8. Map showing average annual recharge simulated for the Death Valley regional groundwater flow system model, with graphs of temporally varying recharge for selected grid cells in the Spring Mountains, Sheep Range, and Pahute Mesa .............19

9. Map showing model grid for the Death Valley regional groundwater flow system ...............22

10. Map showing simulated discharge areas, major recharge areas, and constant-head boundary flows for the Death Valley regional groundwater flow system

11. Histogram showing classification of the Amargosa Desert 31 lithologies into 7 lithology-based texture parameters

12. Maps showing distribution of pilot points and hydraulic conductivity in Pahrump Valley

13. Map showing distribution of zones and pilot points for simulated specific yield in the Death Valley regional groundwater flow system v. 2.0 model

14. Map showing location of well pairs where vertical hydraulic-head gradients are available for use in the Death Valley regional groundwater flow system v. 2.0 model ......34

15. Schematic drawing of implementation of drain penalty into the least-squares objective function

16. Map of interbasin flow observations/prior-information and simulated values in the Death Valley regional groundwater flow system v. 2.0 model, and potential to transmit groundwater

17. Map showing location of transmissivity observations/prior-information used in the Death Valley regional groundwater flow system v. 2.0 model

18. Graphs showing observed/prior-information versus simulated values for steadystate hydraulic head, transient hydraulic-head change, vertical hydraulic-head difference, steady-state discharge, steady-state boundary flow, and steadystate interbasin flow.

19. Map showing well locations with steady-state hydraulic-head residuals and simulated water-level surface in the uppermost active layer of the Death Valley regional groundwater flow system v. 2.0 model

20. Map showing locations where simulated hydraulic heads in layer 1 of the Death Valley regional groundwater flow system v. 2.0 model are above land surface

21. Map showing selected hydrographs showing observed and simulated water levels in pumping areas of the Death Valley regional groundwater flow system model domain

22. Graph showing total water budget for steady-state and transient stress periods of the Death Valley regional groundwater flow system transient model

23. Graph showing relation between prior-information transmissivity and simulated transmissivity in the Death Valley regional groundwater flow system v. 2.0 model

24. Maps showing bulk transmissivity for all model layers in the Death Valley regional groundwater flow system v. 1.0 and v. 2.0 models

25. Bar chart showing composite-scaled sensitivities for all parameters with values greater than $3.5 \times 10^{-2}$ in the Death Valley regional groundwater flow system v. 2.0 model

\section{Plate}

Estimated Potentiometric Surface of the Death Valley Regional Groundwater Flow System, Nevada and California 


\section{Tables}

1. Hydrogeologic units for the Death Valley regional groundwater flow system hydrogeologic framework model

2. Lithologic and textural classes and inferred relative permeability for the Amargosa Desert basin-fill deposits

3. Comparison of simulated cumulative volumetric flow budgets and root mean squared error for 1998 between the Death Valley regional groundwater flow system v. 1.0 and the MODFLOW-2005 converted models

4. Statistical distribution of hydraulic-conductivity values of the Pahrump Valley basinfill deposits

5. Summary of observations/prior-information used in the Death Valley regional groundwater flow system v. 2.0 model

6. Interbasin flow observations/prior-information used in the Death Valley regional groundwater flow system v. 2.0 model and simulated results

7. Contribution of observations/prior-information to the objective function of the sum of squared weighted residuals at the end of calibration of Death Valley regional groundwater flow system v. 2.0

8. Comparison of simulated cumulative volumetric flow budgets and root mean squared error through the 1998 stress period between the Death Valley regional groundwater flow system v. 1.0 and v. 2.0 models 


\section{Conversion Factors}

International System of Units to U.S. customary units

\begin{tabular}{lcl}
\hline \multicolumn{1}{c}{ Multiply } & By & \multicolumn{1}{c}{ To obtain } \\
\hline meter $(\mathrm{m})$ & Length & \\
kilometer $(\mathrm{km})$ & 3.281 & foot $(\mathrm{ft})$ \\
& 0.6214 & mile $(\mathrm{mi})$ \\
\hline square kilometer $\left(\mathrm{km}^{2}\right)$ & Area & \\
\hline & 0.3861 & square mile $\left(\mathrm{mi}^{2}\right)$ \\
\hline cubic meter $\left(\mathrm{m}^{3}\right)$ & Volume & \\
\hline & 35.31 & cubic foot $\left(\mathrm{ft}^{3}\right)$ \\
\hline cubic meter per year $\left(\mathrm{m}^{3} / \mathrm{yr}\right)$ & Flow rate & \\
meter per day $(\mathrm{m} / \mathrm{d})$ & 0.000811 & acre-foot per year $(\mathrm{acre}-\mathrm{ft} / \mathrm{yr})$ \\
meter per year $(\mathrm{m} / \mathrm{yr})$ & 3.281 & foot per day $(\mathrm{ft} / \mathrm{d})$ \\
meter squared per day $\left(\mathrm{m}^{2} / \mathrm{d}\right)$ & 3.281 & foot per year $(\mathrm{ft} / \mathrm{yr})$ \\
cubic meter per day $\left(\mathrm{m}^{3} / \mathrm{d}\right)$ & 10.76 & foot squared $\mathrm{per}$ day $\left(\mathrm{ft}^{2} / \mathrm{d}\right)$ \\
cubic meter per day $\left(\mathrm{m}^{3} / \mathrm{d}\right)$ & 35.31 & cubic foot per day $(\mathrm{ft} / \mathrm{d})$ \\
\hline
\end{tabular}

U.S. customary units to International System of Units

\begin{tabular}{ccc}
\hline Multiply & By & To obtain \\
\hline & Volume & \\
\hline acre-foot (acre-ft) & 1,233 & cubic meter $\left(\mathrm{m}^{3}\right)$ \\
\hline \multicolumn{3}{c}{ Flow rate } \\
\hline acre-foot per year (acre-ft/yr) & 1,233 & cubic meter per year $\left(\mathrm{m}^{3} / \mathrm{yr}\right)$ \\
\hline
\end{tabular}

Temperature in degrees Celsius $\left({ }^{\circ} \mathrm{C}\right)$ can be converted to degrees Fahrenheit $\left({ }^{\circ} \mathrm{F}\right)$ as follows:

$$
{ }^{\circ} \mathrm{F}=\left(1.8 \times{ }^{\circ} \mathrm{C}\right)+32
$$

Temperature in degrees Fahrenheit $\left({ }^{\circ} \mathrm{F}\right) \mathrm{can}$ be converted to degrees Celsius $\left({ }^{\circ} \mathrm{C}\right)$ as follows:

$$
{ }^{\circ} \mathrm{C}=\left({ }^{\circ} \mathrm{F}-32\right) / 1.8
$$

\section{Datums}

Horizontal coordinate information is referenced to the North American Datum of 1983 (NAD 83).

Vertical coordinate information is referenced to the North American Vertical Datum of 1988 (NAVD 88).

Altitude, as used in this report, refers to distance above the vertical datum. 


\section{Abbreviations and Acronyms}

$\begin{array}{ll}\text { 3D } & \text { Three-dimensional } \\ \text { BCF } & \text { Block-Center Flow } \\ \text { BRU } & \text { Belted Range unit } \\ \text { CAU } & \text { Corrective Action Unit } \\ \text { CHVU } & \text { Calico Hills volcanic-rock unit } \\ \text { CFBCU } & \text { Crater Flat-Bullfrog confining unit } \\ \text { CFPPA } & \text { Crater Flat-Prow Pass aquifer } \\ \text { CFTA } & \text { Crater Flat-Tram aquifer } \\ \text { CSS } & \text { Composite-scaled sensitivity } \\ \text { CV } & \text { Coefficient of variation } \\ \text { DOE } & \text { U.S. Department of Energy } \\ \text { DOE/NV } & \text { U.S. Department of Energy, Nevada Operations Office } \\ \text { DRN } & \text { Drain } \\ \text { DVRFS } & \text { Death Valley regional groundwater flow system } \\ \text { ET } & \text { Evapotranspiration } \\ \text { GWSI } & \text { Ground-Water Site Inventory } \\ \text { HFB } & \text { Horizontal-flow barrier } \\ \text { HFM } & \text { Hydrogeologic framework model } \\ \text { HGU } & \text { Hydrogeologic unit } \\ \text { HUF } & \text { Hydrogeologic-Unit Flow } \\ \text { ICU } & \text { Intrusive-rock confining unit } \\ \text { LA } & \text { Limestone aquifer } \\ \text { LCA } & \text { Lower carbonate-rock aquifer } \\ \text { LCA_T1 } & \text { Lower carbonate-rock aquifer (thrusted) } \\ \text { LCCU } & \text { Lower clastic-rock confining unit } \\ \text { LCCU_T1 } & \text { Lower clastic-rock confining unit (thrusted) } \\ \text { LFU } & \text { Lava-flow unit } \\ \text { LSO } & \text { Least-squares objective } \\ \text { MNW } & \text { Multi-node well } \\ \text { NDWR } & \text { Nevada Division of Water Resources } \\ \text { NNSS } & \text { Nevada National Security Site } \\ \text { OAA } & \text { Older alluvial aquifer } \\ \text { OACU } & \text { Older alluvial confining unit } \\ \text { OVU } & \text { Older volcanic-rock unit } \\ \text { PCC } & \text { Parameter correlation coefficient } \\ \text { PVA } & \text { Paintbrush volcanic-rock aquifer } \\ \text { Root mean squared error } \\ \text { Sedimentary-rock confining unit }\end{array}$




$\begin{array}{ll}\text { SOSWR } & \text { Sum of squared weighted residuals } \\ \text { SORT } & \text { Square root } \\ \text { TMVA } & \text { Timber Mountain volcanic-rock unit } \\ \text { UCA } & \text { Upper carbonate-rock aquifer } \\ \text { UCCU } & \text { Upper clastic-rock confining unit } \\ \text { UGTA } & \text { Underground Test Area } \\ \text { USGS } & \text { U.S. Geological Survey } \\ \text { VSU } & \text { Volcanic- and sedimentary-rock unit } \\ \text { WVU } & \text { Wahmonie volcanic-rock unit } \\ \text { XCU } & \text { Crystalline-rock confining unit } \\ \text { YAA } & \text { Younger alluvial aquifer } \\ \text { YACU } & \text { Younger alluvial confining unit } \\ \text { YVU } & \text { Younger volcanic-rock unit }\end{array}$




\title{
An Update of the Death Valley Regional Groundwater Flow System Transient Model, Nevada and California
}

\author{
By Wayne R. Belcher, Donald S. Sweetkind, Claudia C. Faunt, Michael T. Pavelko, and Mary C. Hill
}

\section{Abstract}

Since the original publication of the Death Valley regional groundwater flow system (DVRFS) numerical model in 2004, more information on the regional groundwater flow system in the form of new data and interpretations has been compiled. Cooperators such as the Bureau of Land Management, National Park Service, U.S. Fish and Wildlife Service, the Department of Energy, and Nye County, Nevada, recognized a need to update the existing regional numerical model to maintain its viability as a groundwater management tool for regional stakeholders. The existing DVRFS numerical flow model was converted to MODFLOW-2005, updated with the latest available data, and recalibrated. Five main data sets were revised: (1) recharge from precipitation varying in time and space, (2) pumping data, (3) water-level observations, (4) an updated regional potentiometric map, and (5) a revision to the digital hydrogeologic framework model.

The resulting DVRFS version 2.0 (v. 2.0) numerical flow model simulates groundwater flow conditions for the Death Valley region from 1913 to 2003 to correspond to the time frame for the most recently published (2008) water-use data. The DVRFS v 2.0 model was calibrated by using the Tikhonov regularization functionality in the parameter estimation and predictive uncertainty software PEST. In order to assess the accuracy of the numerical flow model in simulating regional flow, the fit of simulated to target values (consisting of hydraulic heads and flows, including evapotranspiration and spring discharge, flow across the model boundary, and interbasin flow; the regional water budget; values of parameter estimates; and sensitivities) was evaluated. This evaluation showed that DVRFS v. 2.0 simulates conditions similar to DVRFS v. 1.0. Comparisons of the target values with simulated values also indicate that they match reasonably well and in some cases (boundary flows and discharge) significantly better than in DVRFS v. 1.0.

\section{Introduction}

The U.S. Geological Survey (USGS) has revised the regional-scale Death Valley regional groundwater flow system (DVRFS) numerical model with new data and interpretations since the original numerical flow model was published in 2004 (Belcher (2004); re-published as Belcher and Sweetkind [2010]). Since the original publication of the DVRFS flow model, additional data have been collected and interpretations have been made. Cooperators such as the Bureau of Land Management, National Park Service, U.S. Fish and Wildlife Service, the Department of Energy, and Nye County, Nevada, recognized a need to update the existing regional numerical flow model to maintain its viability as a groundwater management tool for regional stakeholders. For the purposes of this report, the version of the DVRFS numerical flow model documented in Belcher and Sweetkind (2010) and Faunt, Blainey, and others (2010) is designated as DVRFS v. 1.0. The updated version, as presented in this report, is referred to as DVRFS v. 2.0.

Knowledge of basin water balances and the magnitude of interbasin groundwater flow is the basis for regional groundwater management and water-resource planning in the Great Basin of Nevada (Scott and others, 1971). Rapid population growth, arid conditions, and increased water use have led to development of available groundwater resources. Groundwater use in some alluvial-fill basins has resulted in continued waterlevel declines and land subsidence. Adjacent bedrock aquifers are increasingly being targeted for additional development. Such groundwater development may potentially impact local and regional water quantity and quality, existing water rights, and wildlife habitats. An understanding of hydrogeologic processes that control the rate and direction of groundwater flow in southern Nevada is necessary to assess the potential effects of any proposed large-scale groundwater development.

Potential water-resource conflicts exist because of disparate interests in the region, particularly with respect to the development of groundwater resources to meet agricultural, municipal, and industrial water demand and the need to protect habitat for endangered and threatened species. Water demands in the Amargosa Farms area from agricultural and suburban development, and rapidly urbanizing areas in Las Vegas and Pahrump Valleys place increasing pressure on existing groundwater 
resources. In addition, several solar-energy facilities have been proposed within the Death Valley region; water demands for these facilities will vary. Natural groundwater discharge at springs and seeps sustains habitat for numerous species, many of which are threatened, endangered, or otherwise considered sensitive.

In 2004, the USGS documented a calibrated numerical flow model of the DVRFS (Belcher, 2004). The model, DVRFS v. 1.0, incorporated elements of several precursor numerical models but defined the boundaries of the regional flow system slightly different than in previous versions. The model simulates transient groundwater flow conditions in the DVRFS from 1913 through 1998. The report was subsequently revised and published as a USGS Professional Paper (Belcher and Sweetkind, 2010). Since release of DVRFS v. 1.0 in 2004, continued use of the model by cooperators, stakeholders, and interested parties in the region has demonstrated the need to improve specific aspects (such as the flow into northern Yucca Flat and parts of the Amargosa Desert), to update it with more recently acquired geologic and hydrologic data, and to extend the simulation period.

\section{Background}

More than 30 years of groundwater flow modeling of the DVRFS has produced a succession of models representing the hydrogeologic framework and groundwater flow system (Belcher and others, 2010). Regional-scale groundwater flow models developed over the last two decades have provided new insights into groundwater flow in the Death Valley region. Successive models incorporated increasing levels of hydrogeologic complexity and computational sophistication in an effort to more completely address the complex water-resource issues in the region. Each of these studies attempted to model the surface water and groundwater hydrology and hydrogeologic framework, but the heterogeneity of the flow system was by necessity oversimplified because practical methods for representing the complex hydrogeologic framework were not available. With each model, investigators have refined the understanding of the three-dimensional (3D) nature of the DVRFS.

Early 2D and 3D groundwater flow models developed in the 1980s contained considerable abstractions of the natural hydrogeologic conditions and depended on lumped system parameters (Waddell, 1982; Czarnecki and Waddell, 1984; Rice, 1984; Czarnecki, 1985; Sinton, 1987; Prudic and others, 1995). Although these models were considered adequate for their intended purposes at the time, the results of these investigations indicated that lumped-parameter representations did not adequately depict vertical groundwater flow, sub-basin groundwater flow, steep hydraulic gradients, and physical subbasin boundaries.

In contrast, the more complex groundwater flow models developed in recent investigations allow for the examination of the spatial and process complexities of the 3D hydrogeologic system (IT Corporation, 1996a; D'Agnese and others,
1997; D'Agnese and others, 2002). These more geologically and hydrologically representative flow models usually require a 3D hydrogeologic framework model (HFM) to define the complexities of the hydrogeologic unit (HGU) geometry and structure. The use of a 3D HFM allows workers to model the hydrogeologic complexities of a groundwater system and use it as input to a numerical flow model.

Belcher (2004) and Belcher and Sweetkind (2010) documented the construction and calibration of a regional groundwater flow numerical model of the DVRFS. DVRFS v. 1.0 simulates groundwater flow in the Death Valley region for use by a variety of regional stakeholders. DVRFS v. 1.0 used an earlier version of MODFLOW, MODFLOW-2000 with related packages (Hsieh and Freckelton, 1993; Anderman and Hill, 2000; Harbaugh and others, 2000; Hill and others, 2000). It simulates a pre-development steady-state stress period and transient stress periods from 1913 through 1998 (Faunt, Blainey, and others, 2010).

\section{Purpose and Scope}

In October 2006, the USGS began a study with the agencies of the Department of the Interior (DOI), Department of Energy (DOE), and Nye County, Nevada, to update and revise the DVRFS v. 1.0 model (Belcher and Sweetkind, 2010; Faunt, Blainey, and others, 2010). Cooperating DOI agencies included the Bureau of Land Management, National Park Service, and the U.S. Fish and Wildlife Service.

Several aspects of the DVRFS v. 1.0 flow model were modified for DVRFS v. 2.0, including (1) adding revised and additional pumping estimates, (2) adding additional water-level data, (3) extending the period of simulation, (4) targeting digital hydrogeologic framework model revisions in the vicinity of the Nevada National Security Site (NNSS), (5) refining the hydrogeology in the Amargosa Desert in an effort to improve flow-model calibration of the area around Ash Meadows, and (6) re-calibration of the regional numerical model. These updates, revisions and refinements, have resulted in an updated, calibrated regional numerical flow model herein referred to as DVRFS v. 2.0.

This report describes the various aspects of the updates to the regional numerical model including (1) construction of a lithology-based digital HFM of the southern part of the Amargosa Desert, (2) revisions to the regional HFM, (3) updates to the model codes, (4) updates to the pumpage and hydraulic-head data sets, (5) extension of the simulation period to 2003, and (6) re-calibration of the regional groundwater flow model. Model input files used updated pumpage data compiled by Moreo and Justet (2008) and water-level data compiled by Pavelko (2010). The updated DVRFS v. 2.0 model uses the most recent version of the MODFLOW simulation code, MODFLOW-2005 (Harbaugh, 2005) and PEST (Doherty, 2005).

The DVRFS model is intended to meet the long-term needs of a number of Federal, State, and local entities that require a hydrogeologic and hydrologic conceptualization and 
simulation of the regional flow system. As such, the purpose of the updated regional numerical model remains very similar to that described in Belcher and Sweetkind (2010), which is to produce a transient model that simulates the groundwater conditions of the model domain through time and may be used to (1) inform definition of boundary conditions for the Underground Test Area (UGTA) Corrective Action Units (CAUs) on the NNSS, (2) evaluate the effects of changes in groundwater-system fluxes, regardless of whether the changes are natural or human-induced, (3) provide a technical basis to inform evaluations and decisions on groundwater availability to meet water demands on and off the NNSS, (4) address concerns about potential declines in groundwater levels as a result of increased pumping in local areas, (5) provide a framework for determining effective contaminant source plume, ambient trend, and point-of-use groundwater-quality monitoring locations, and (6) test alternative conceptual models of the regional groundwater system.

The scope of the DVRFS v. 2.0 model can be summarized as follows:

1. The study area was limited to the DVRFS region as defined in Belcher and Sweetkind (2010).

2. A single hydrogeologic framework was used; alternative interpretations or multiple realizations were not used.

3. The period of simulation consists of a steady-state prepumping condition (prior to 1913) and a transient condition (1913 through 2003).

4. Although much of the groundwater flow through the consolidated rock is likely through fractured media, porous-media groundwater flow is simulated; owing to the regional scale of the flow model, an equivalent porous medium is assumed.

5. Spatial variations in groundwater density due to changes in temperature or chemistry are assumed to be negligible and are not accounted for in the flow model.

6. The pre-development conditions (prior to 1913) are assumed to be representative of steady-state conditions.

7. Constant transmissivity is used to simulate unconfined flow conditions to improve execution times of the model runs.

8. The term "observation/prior-information" refers to values or target values developed from field measurements, estimates, and (or) interpretations that are compared to simulated values (model outputs) to constrain the regression during calibration.

9. Hydraulic properties within defined model zones are assumed to be homogeneous and representative of regional conditions.

10. Pilot points were used to vary horizontal hydraulic conductivity within specified areas of the flow system.
The DVRFS is an extremely complex geologic and hydrogeologic framework in which parts of the flow system are inferred to exist at great depth, below the depth of geologic or hydrologic control. Some of the rocks at depth are inferred to be components of important regional aquifer systems that must be included in any defensible model that is intended for use by all the regional stakeholders in the DVRFS. For example, a deep regional carbonate-rock aquifer system that is part of the regional groundwater system is a key potential future source of water in the region and the focus of many of the concerns with respect to both the proposed repository at Yucca Mountain and the effects of other activities (such as water supply and contaminant migration) at the NNSS. Other rocks at depth serve as important confining units and barriers that control groundwater flow to springs and evapotranspiration (ET) areas. The DVRFS is a 3D system and needs to be simulated in that manner, even if much of the calibration data are derived from or represent shallow parts of the system.

Detailed background information such as site description, hydrogeology, hydrology, hydrologic budget components, and the initial construction of the digital hydrogeologic framework and numerical flow model is contained in Belcher and Sweetkind (2010), and the reader is referred to that report and the references therein. This report only covers the specific changes to the DVRFS v. 1.0 to produce the DVRFS v. 2.0 numerical flow model and includes the following modifications, updates, and improvements to the DVRFS v. 1.0 model:

- Improved the HFM including new data and a revised configuration of the lower carbonate-rock aquifer in Yucca Flat.

- Updated pumping and water-level databases through 2003.

- Added variable recharge from precipitation based on variation of precipitation through time.

- Converted the numerical model to MODFLOW-2005 and used the PEST code (Doherty, 2005) for calibration.

- Updated the regional potentiometric surface.

- Initially used an updated potentiometric surface to act as the top surface of the model with updated potentiometric surface (initially).

- Modified layering scheme to reduce lumping of hydrogeologic units (HGUs).

- Extended the simulation period through 2003 with a pre-1913 steady-state stress period and 92 transient stress periods (1913 through 2003).

- Added new data and estimates used for calibration such as interbasin flow and transmissivity.

- Used pilot points in some basin-fill deposits to estimate parameters of horizontal hydraulic conductivity and specific yield. 


\section{Acknowledgments}

This work was completed by the USGS as part of four cooperative programs: (1) DOE, National Nuclear Security Administration, Nevada Site Office, under Interagency Agreement DE-AI52-01NV13944, (2) DOE, Office of Civilian Radioactive Waste Management, under Interagency Agreement DE-AI28-02RW12167, and (3) Bureau of Land Management, National Park Service, U.S. Fish and Wildlife Service, and Nye County, Nevada, under a multiagency agreement to revise and update the DVRFS v. 1.0 model.

\section{Site Description}

The DVRFS is in the southern Great Basin, a subprovince of the Basin and Range physiographic province (Fenneman, 1931). The DVRFS is in south-central Nevada and southeastern California and is bounded by latitudes 35 degrees 30 minutes North and 38 degrees 15 minutes North and by longitudes 115 degrees 00 minutes West and 118 degrees 00 minutes West (fig. 1). It covers an area of approximately 100,000 square kilometers $\left(\mathrm{km}^{2}\right)$ in Nevada and California. Major topographic and hydrologic features of the flow system are shown on figure 1. The flow model area includes 70,000 $\mathrm{km}^{2}$ in Nye, Clark, Lincoln, and Esmeralda Counties in Nevada and Inyo County in California (fig. 1). The DVRFS includes several large valleys, including the Amargosa Desert, Pahrump Valley, and Death Valley. The region also includes several major mountain ranges including the Spring Mountains and the Panamint, Sheep, Amargosa, Kawich, Kingston, Pahranagat, Timpahute, and Last Chance Ranges. Late Cenozoic tectonic activity accounts for much of the observed topographic relief across the Death Valley region (Grose and Smith, 1989). Altitudes range from 86 meters (m) below sea level at Death Valley to 3,600 $\mathrm{m}$ above sea level at Charleston Peak in the Spring Mountains. The relief between valleys and adjoining mountains locally exceeds $500 \mathrm{~m}$ (Bedinger and others, 1989a). The maximum relief, 3,500 m, occurs on the west side of Death Valley.

Climatic conditions in the Death Valley region vary significantly and are primarily controlled by altitude. The northern part of the region, including the Cactus, Kawich, and Timpahute Ranges (fig. 1), forms part of the Great Basin Desert and is characterized by warm, dry summers and cold, dry winters. The southern part of the region, including Death Valley and the eastern Mojave Desert, is characterized by hot, dry summers and warm, dry winters (Benson and Darrow, 1981).

Most of the land in the Death Valley region is owned by the U.S. Government and is administered by various Federal agencies. Tribal lands of the Timbisha Shoshone exist in the Death Valley region. Privately-owned land is scattered throughout the region, but most private ownership is concentrated near the agricultural centers of Amargosa Desert and Pahrump Valley, the mining community of Beatty, Nev., and the towns of Shoshone, Tecopa, and Baker, Calif. (fig. 1).
Other than federal activities such as the defense and the Department of Energy, the major land-use activities in the region are agriculture, livestock ranching, recreation, and mining. Water within the Death Valley region is used mostly for domestic, commercial, agricultural, livestock, military, and mining purposes. Water resources in the Amargosa Desert support biological communities protected by the National Park Service in Death Valley and by the U.S. Fish and Wildlife Service at Ash Meadows National Wildlife Refuge. This includes the Devils Hole pupfish (Cyprinidon diabolis), whose continued existence depends on stable pool levels in Devils Hole.

\section{Geology}

The Death Valley region has a long and complex geologic history that includes marine and nonmarine sedimentation and compressional and extensional tectonics (Stuckless and O'Leary, 2007; Sweetkind and others, 2010). Consequently, diverse rock types and deformational structures are generally juxtaposed such that subsurface conditions are variable and complex. Knowledge of the geology beneath alluvial basins is sparse and indirect, complicating the understanding of the hydrogeologic framework. Much of the following description of the hydrogeologic framework of the DVRFS has been generalized from Sweetkind and others (2010, fig. B-1). The regional geology consists of the following major lithostratigraphic groups:

1. Proterozoic and Early Cambrian crystalline and siliciclastic rocks,

2. Paleozoic carbonate and fine-grained siliciclastic rocks,

3. Mesozoic siliciclastic and intrusive rocks,

4. Tertiary tuffs, lava flows, and volcaniclastic rocks, and

5. Cenozoic basin-fill deposits, predominantly alluvial and colluvial deposits and lesser amounts of basalt, aeolian, paludal (marsh), and playa sediments.

The hydrologic basement of the DVRFS consists of lowpermeability Early to Middle Proterozoic crystalline rocks and minor Late Proterozoic siliciclastic rocks. Although some Early Proterozoic rocks are exposed in the region, most rocks are of Late Proterozoic age.

The eastern and southern parts of the Death Valley region lie within the carbonate-rock province of the Great Basin (Prudic and others, 1995), which is characterized by thick sequences of carbonate rocks. These rocks form a generally deep regional aquifer within the groundwater flow system. These carbonate rocks also allow transfer of groundwater between basins in the DVRFS (Winograd and Thordarsen, 1975; D'Agnese and others, 1997, p. 5). In valleys such as the Amargosa Desert and southern Indian Springs Valley (fig. 1), and possibly in eastern Jackass Flats, interbasin movement of groundwater (groundwater flow through bedrock mountain ranges between fault-block basins) generally results in upward flow from the deep carbonate rocks into the overlying 


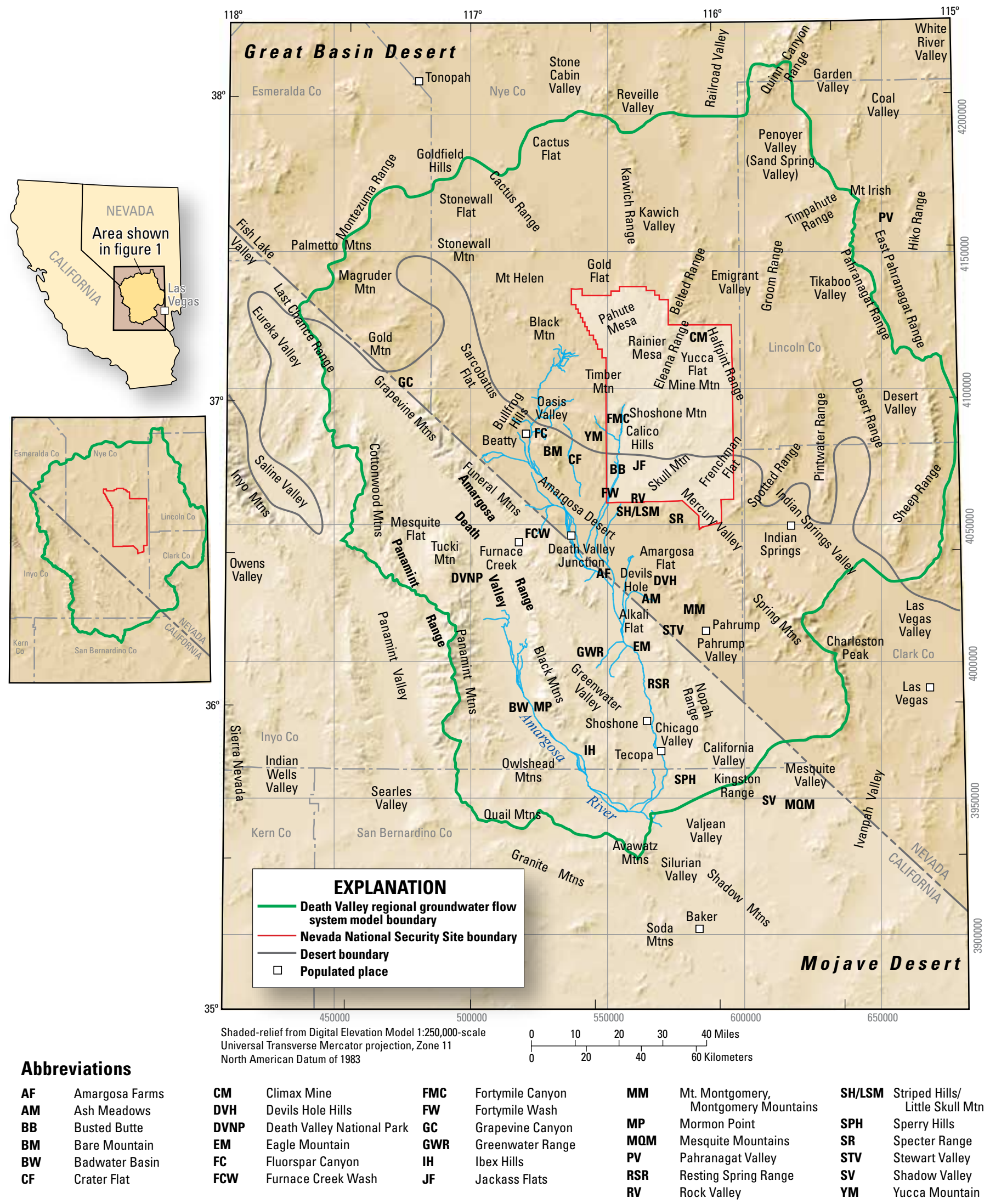

Figure 1. Geographic and prominent topographic features in the Death Valley regional groundwater flow system area, Nevada and California. 
basin-fill materials (Winograd and Thordarson, 1975), but this may be reversed in some areas.

Consolidated sedimentary rocks of Mesozoic age are of minor importance in the Spring Mountains (fig. 1). Small Cretaceous-age plutons occur in the northeastern part of the NNSS; Mesozoic-age intrusive rocks are more common in the southwestern and western parts of the DVRFS.

The northwestern part of the DVRFS generally is underlain by Tertiary silicic volcanic rocks that are part of the southwestern Nevada volcanic field (fig. 4 in Laczniak and others, 1996). The hydraulic properties of the volcanic rocks are governed chiefly by the mode of eruption and cooling, by the extent of primary and secondary fracturing, and by the degree to which secondary alteration (crystallization of volcanic glass and alteration to zeolites) has affected primary permeability (Laczniak and others, 1996, p. 15). On a regional scale, the volcanic rocks generally are in hydraulic connection with overlying basin-fill deposits and may be in hydraulic connection with underlying carbonate rocks as well.

Unconsolidated Cenozoic basin-fill sediments consist of coarse-grained alluvial and colluvial deposits, fine-grained basin axis deposits, and local limestones and spring discharge deposits. Cenozoic volcanic rocks are also present as basalt cones and flows and surface outcrops of rhyolite lava flows, along with volcanic rocks that overlie the volcanic rocks of the southwestern Nevada volcanic field.
These rocks and unconsolidated deposits form the system through which groundwater flows. They can be grouped into units of similar hydrogeologic characteristics called hydrogeologic units (HGUs). An HGU has considerable lateral extent and has reasonably distinct hydrologic properties because of its physical (geological and structural) characteristics. Sweetkind and others (2010) discuss the derivation of the HGUs for the DVRFS and describe those used in the DVRFS flow model.

\section{Overview of the Groundwater Flow System}

Groundwater movement in the regional flow system generally originates as underflow across the lateral boundaries of the DVRFS, mostly through the carbonate rocks (fig. 2). It may also originate as localized asymmetric radial flow of recharge from precipitation on mountains and other highlands located principally along the periphery of and within the system. The overall flow system, therefore, can be thought of as a set of relatively shallow, localized flow systems that are superimposed on a deeper regional system (fig. 2). Within the flow system, the overall movement of groundwater is from the source areas near the margins of the system to the regional discharge area in the floor of Death Valley, and regional springs and discharge areas (such as the Furnace Creek Springs) above the floor of Death Valley. Regional groundwater is also

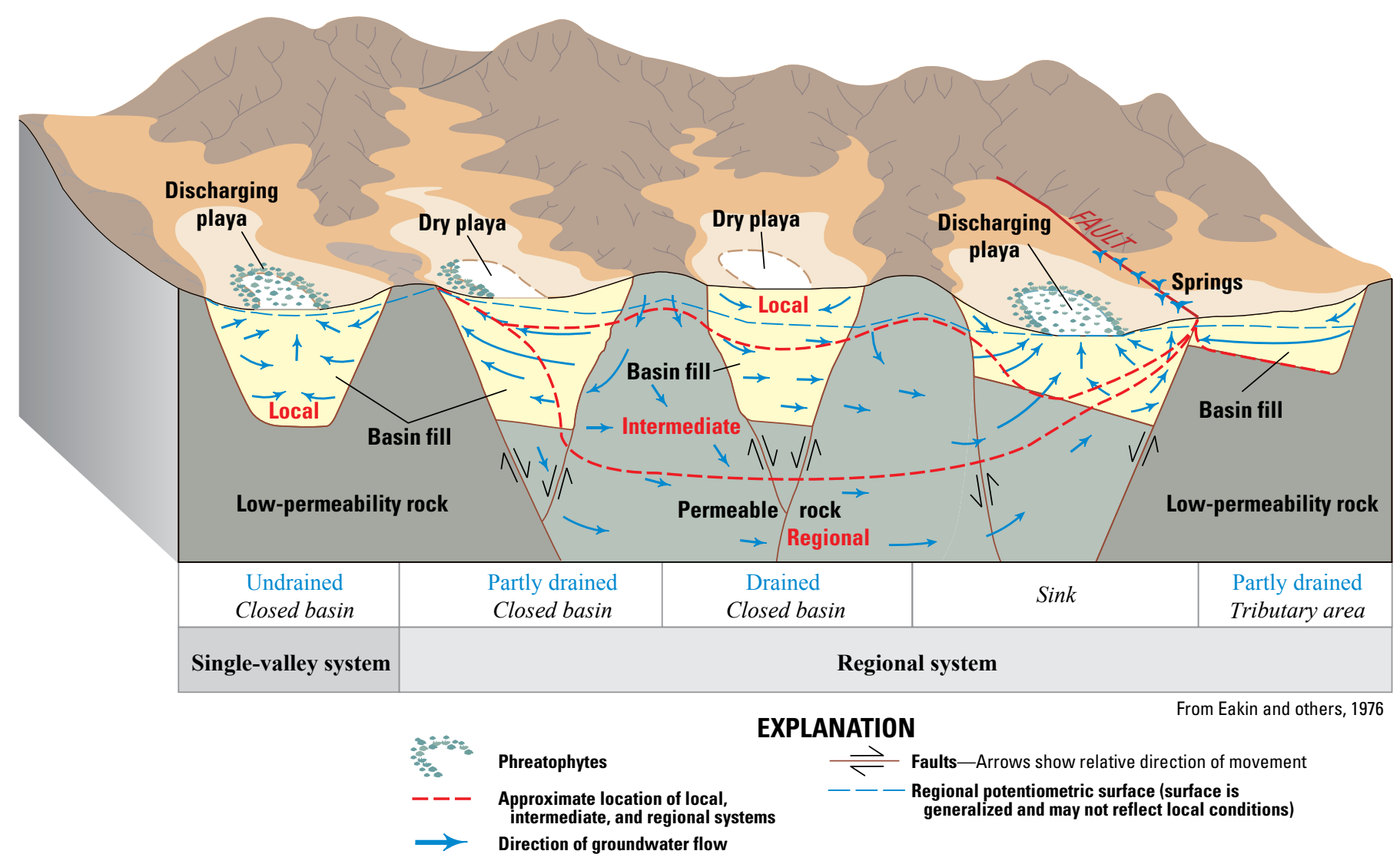

Figure 2. Diagram of the Great Basin illustrating the relations between mountain blocks, intermontane basins, and groundwater flow. 
discharged at intermediate points at Oasis Valley and Ash Meadows. Groundwater flow from the Panamint Range (fig. 1) on the western boundary of the regional system is generally eastward to northeastward. Regional flow toward Death Valley is to the southwest from the northern and northeastern parts of the DVRFS, and approximately westward from the Spring Mountains and the southeast quadrant of the regional flow system, although flow paths are locally variable as a result of geologic complexities (Faunt, Blainey, and others, 2010). Groundwater movement may also be out of the DVRFS into the northwest part of Las Vegas Valley (Faunt, Blainey, and others, 2010). Fractures and faults within the consolidated HGUs constitute the dominant pathways for regional groundwater flow (Faunt, 1997). The presence, orientation, and type of fault provides major controls on groundwater flow (Faunt, 1997, p. 24-31).

The concept of interbasin flow in the Great Basin was established by scientific studies over the past century. Interbasin flow, although it is not uniform between basins, is common and the flow rate is a function of the recharge and the distribution of hydraulic conductivity of the intervening rocks. Knowledge of interbasin groundwater flow through bedrock and basin-fill deposits is greatly relevant for regional groundwater management and water-resource planning in the Great Basin (Belcher and others, 2009).

Groundwater enters the DVRFS as interbasin flow and as recharge from precipitation in upland areas. Because of present-day arid conditions, recharge from precipitation is generally restricted to higher altitudes, and virtually no recharge from precipitation occurs in lowland valley areas where evapotranspiration generally exceeds precipitation. In addition, little or no perennial surface water is present in the lowlands and on valley floors (Winograd and others, 2005). Groundwater flow paths within the system diverge from the highlands and are superimposed on deeper regional flow paths that are controlled largely by flow in the regional carbonaterock aquifer. The overall direction of flow in the deep regional system is toward the regional hydrologic discharge area in Death Valley, although there are a number of local discharge areas along these general flow paths, such as Ash Meadows, Oasis Valley, and the Amargosa River.

Regional groundwater flow in the DVRFS is described in terms of the northern, central, and southern Death Valley subregions (fig. 3) of D'Agnese and others (1997, p. 62-67). The subregions are further subdivided into groundwater sections, and the sections in the central Death Valley subregion are grouped into groundwater basins. These subregions, sections and basins are used for descriptive purposes only, and the boundaries do not define independent flow systems. The subregions, basins, and sections are delineated primarily by (1) location of recharge areas, (2) regional hydraulic gradients, (3) distribution of aquifers, structures, and confining units that affect flow, (4) location of major discharge areas, and (5) hydrochemical composition of the groundwater. Flow directions across the system boundary are based on the lateral flow estimates provided in Harrill and Bedinger (2010). More information on the subregional flow systems is presented in Faunt, D'Agnese, and O'Brien (2010).

\section{Hydrogeologic Framework Model and Structure Revisions}

The hydrologic framework for DVRFS v. 1.0 and DVRFS v. 2.0 describes the $3 \mathrm{D}$ distribution of the HGUs of the regional flow system (Faunt, Sweetkind, and Belcher, 2010). The hydrogeologic setting for pre-Cenozoic rocks of the DVRFS, particularly in the vicinity of the NNSS, was established by Winograd and Thordarson (1975). Subsequent utilization of HGUs has occurred in conceptualization and numerical groundwater flow models of the region (Laczniak and others, 1996; IT Corporation, 1996b; D'Agnese and others, 1997; Belcher and Sweetkind, 2010). The hydrogeologic framework for Cenozoic units has varied among investigators, depending on the scale of investigation and level of detail (Prothro and others, 2009; Sweetkind and others, 2010).

The 3D configuration of HGUs within the DVRFS is represented by a digital 3D HFM, a computer-based geometric and volumetric model of the HGUs and major hydrogeologic structures in the DVRFS (Faunt, Sweetkind, and Belcher, 2010). The 3D HFM defines the 3D geometries of HGUs by using surface and subsurface geologic information, such as digital elevation models, geologic maps, borehole information, geologic and hydrogeologic cross sections, and other 3D computer models (Faunt, Sweetkind, and Belcher, 2010). The digital 3D HFM is input to the numerical groundwater flow model through the Hydrogeologic-Unit Flow (HUF) package (Anderman and Hill, 2000, 2003).

Use of the DVRFS v. 1.0 numerical model (Belcher, 2004) by regional cooperators and stakeholders revealed the need for targeted revisions to the 3D HFM to better represent local conditions and to improve consistency with detailed site-scale 3D HFMs at the NNSS. Revisions were made to the DVRFS v. 1.0 HFM on the basis of a (1) comparison of the altitudes of HGU tops and fault locations with site-scale HFMs at the NNSS in the vicinity of Yucca Flat, (2) better definition of the characteristics of highly heterogeneous basin-fill deposits in the Amargosa Desert in Nevada and California, and (3) revised representation of hydrologically significant faults.

\section{Review of Existing Hydrogeologic Framework Model}

The HFM for DVRFS v. 1.0 has 27 HGUs (Faunt, Sweetkind, and Belcher, 2010; Sweetkind and others, 2010). The HGUs used in the revised HFM are essentially unchanged in name, number of units, and stratigraphic order from those used in DVRFS v. 1.0 (table 1). As part of the present update, new geologic and geophysical data gathered as part of this study were used as a basis to modify the altitudes of HGU tops, not to define new units. One important correction to the listing of HGUs from the Faunt, Sweetkind, and Belcher (2010) HFM is the revision of stacking order such that thrusted Paleozoic units occur at the top of the Paleozoic stratigraphic section (table 1). The units were constructed properly, but the published table listed an incorrect stacking order. 


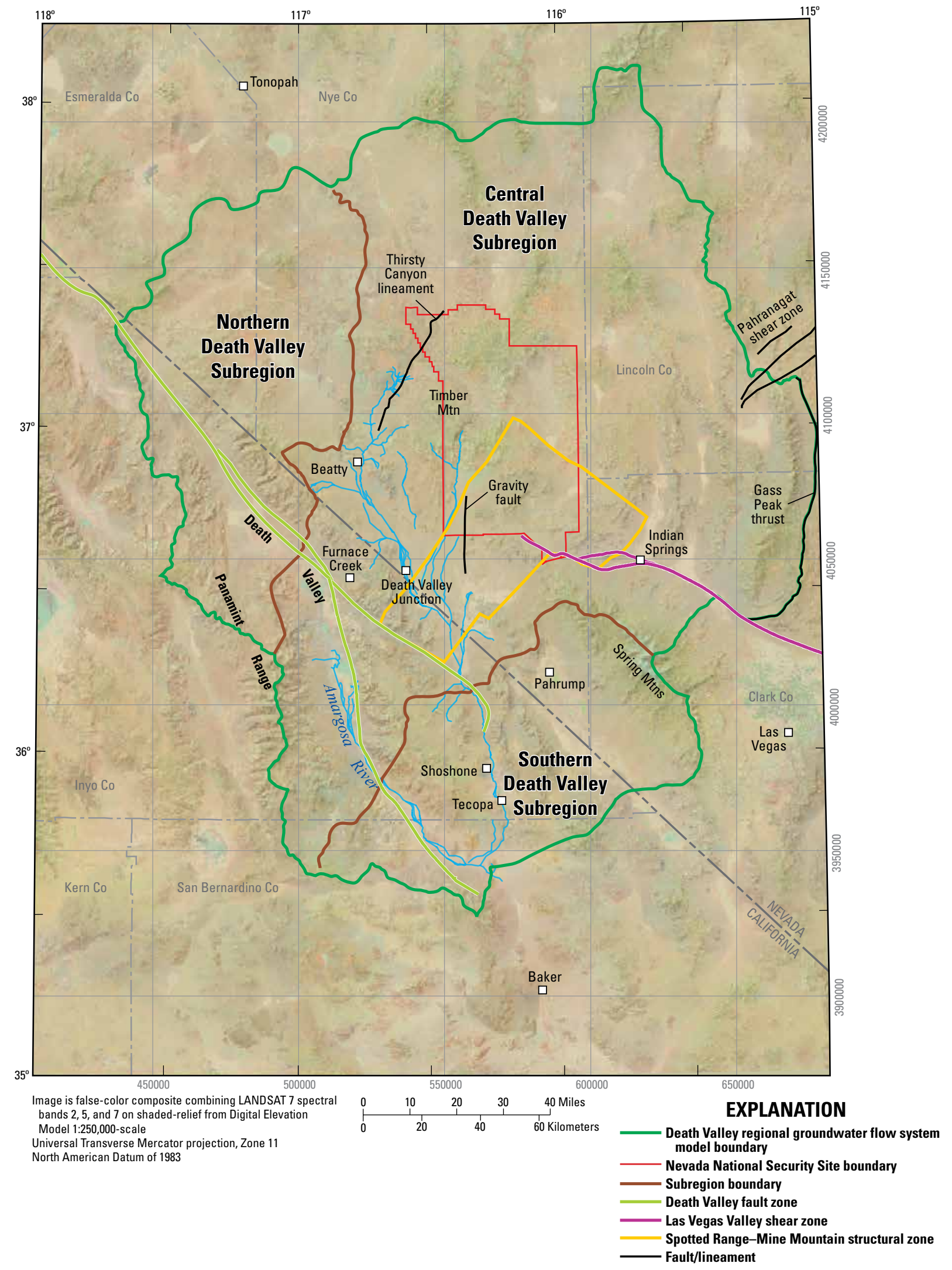

Figure 3. Subregions, Amargosa River drainage, and fault, shear, and structural zones in the Death Valley regional groundwater flow system area. 
Table 1. Hydrogeologic units for the Death Valley regional groundwater flow system hydrogeologic framework model.

[Stacking order, the order that gridded surfaces were entered into the model during construction, with 1 being first and 27 being last; NNSS, Nevada Nuclear Security Site; SWNVF, southwestern Nevada volcanic field]

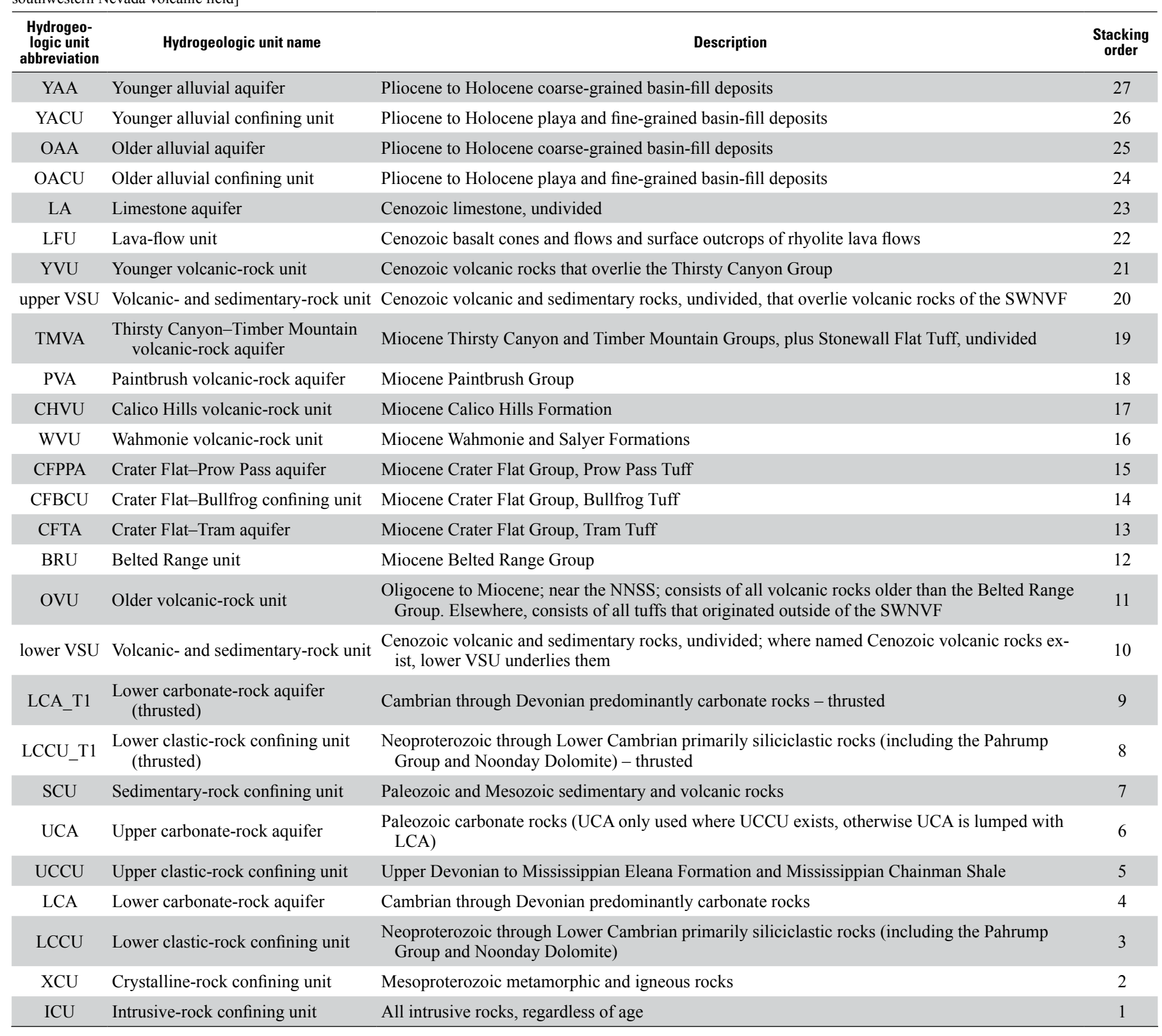

The pre-Cenozoic consolidated-rock section follows the previously defined HGUs. Three low-permeability units occur at the base of the HGU stack and represent the hydraulic basement of the DVRFS (D'Agnese and others, 1997; Faunt, Sweetkind, and Belcher, 2010; Sweetkind and others, 2010). These include the crystalline-rock confining unit (XCU), the lower siliciclastic-rock confining unit (LCCU), and the intrusive-rock confining unit (ICU). Small quantities of water may pass through these units or be stored in fractures, but in general, the fractures are poorly connected and the unit impedes groundwater flow (Winograd and Thordarson, 1975).

Overlying the low-permeability hydraulic basement is the lower carbonate-rock aquifer (LCA, table 1), a major regional aquifer for the eastern two-thirds of the Great Basin, including the Death Valley region (Winograd and Thordarson, 1975; Bedinger and others, 1989a; Harrill and Prudic, 1998). The rocks of the LCA have an aggregate thickness of as much as $8,000 \mathrm{~m}$ and are generally the most permeable rocks in the region (Bedinger and others, 1989b; Belcher and others, 2001). Where hydraulically connected, the carbonate rocks provide a path for interbasin flow (Harrill and others, 1988; D'Agnese and others, 1997; Harrill and Prudic, 1998). In the vicinity of the NNSS, the LCA is overlain by the upper siliciclastic-rock confining unit (UCCU; table 1). The presence of the UCCU may account for many of the steep hydraulic gradients observed west of Yucca Flat and north of Jackass Flats at 
the NNSS (Winograd and Thordarson, 1975; Fridrich and others, 1994; D'Agnese and others, 1997). Where the UCCU is present, the regional carbonate-rock aquifer is divided into the lower (LCA) and upper (UCA) carbonate-rock aquifer. In the southeast part of the DVRFS where the UCCU is absent, the carbonate rocks are considered to be a single unit (Sweetkind and others, 2010). A sedimentary-rock confining unit (SCU) occurs locally at the top of the pre-Cenozoic stratigraphic section. Thrust faults in the DVRFS juxtapose HGUs of contrasting hydrologic properties and complicate the groundwater flow patterns by serving as local flow barriers (Winograd and Thordarson, 1975; McKee and others, 1998). Where thrust faults create a stratigraphic repetition of HGUs, they introduce numerical difficulties into digital HFMs. Where repetition occurs, the thrusted areas are treated as unique HGUs for the LCA and LCCU (LCA_T and LCCU_T, table 1).

The HGUs of Cenozoic age consist of rocks and unconsolidated sediments, and are grouped into eight HGUs representing volcanic rocks of the southwestern Nevada volcanic field and older volcanic centers (OVU, BRU, CFTA, CFBCU, CFPPA, WVU, PVA, and TMVA) ( Faunt, Sweetkind, and Belcher, 2010; Sweetkind and others, 2010), two HGUs representing local younger volcanic rocks (LFU and YVU), three HGUs representing consolidated basin-fill deposits (LA, and upper and lower VSU), two HGUs representing local younger volcanic rocks (LFU and YVU), and four HGUs representing unconsolidated basin-fill sediments (OACU, OAA, YACU, and YAA) (table 1). Volcanic-rock units are defined by grouplevel stratigraphic designations that are based on geologic map compilations (Slate and others, 2000; Workman and others, 2002), geologic cross sections (Sweetkind, Dickerson, and others, 2001), and NNSS borehole lithologic data (Wood, 2009).

The HFM consists of a sequence of continuous numerical grids that represent tops of HGUs (horizons). HFM grid cells are $1,500 \mathrm{~m}$ by $1,500 \mathrm{~m}$ in horizontal dimensions and are oriented north-south. Faults are addressed within the HFM as abrupt changes in altitudes of HGU tops and by the use of thrusted units as separate HGUs to facilitate unit stacking. Faults are further addressed as barriers between grid nodes within the numerical flow model. The HFM represents the altitude of each HGU top as continuous data, where each horizon is defined by a grid that has an altitude value for every grid node across the entire study area. Where a deep HGU is exposed at land surface in the HFM, all overlying horizons have the same land-surface altitude and zero thickness. Similarly, pinch out of HGUs is simulated by having the absent HGU have the same top surface altitude as the HGU underlying it. Regional-scale HGUs in the HFM were defined from land surface to $4,000 \mathrm{~m}$ below sea level to encompass nearly all of the aquifer units in the region.

\section{Revision of the Regional Hydrogeologic Framework Model in the Vicinity of Yucca Flat}

The DVRFS v. 1.0 HFM (Faunt, Sweetkind, and Belcher, 2010) included geologic detail from site-scale geologic framework models in the vicinity of Pahute Mesa (McKee and others, 2001; Bechtel Nevada, 2002) and Yucca Mountain (Bechtel SAIC Company, 2002). These site-scale HFMs provide greater detail of the geometry of Cenozoic volcanic-rock HGUs in areas critical to groundwater flow and monitoring of radionuclide transport, and are much more detailed than the regional HFM in terms of units and discretization. Since the construction of the DVRFS v. 1.0 HFM, four site-scale HFMs were constructed for parts of the NNSS as part of the U.S. Department of Energy's Underground Test Area (UGTA) Project. These HFMs provide detailed hydrogeologic frameworks in the vicinity of Pahute Mesa (Bechtel Nevada, 2002), Frenchman Flat (Bechtel Nevada, 2005), Yucca Flat-Climax Mine (Bechtel Nevada, 2006) and Rainier Mesa-Shoshone Mountain (National Security Technologies, LLC, 2007).

Although it was beyond the scope of this model update to attempt to make the DVRFS 3D HFM consistent with the results of all four site-scale HFMs at the NNSS, the DVRFS v. 1.0 HFM was inspected to identify areas that differ greatly from the site-scale HFMs or result in different numerical results, requiring modification of the regional-scale HFM. The area where differences between the regional and site-scale HFMs produced different numerical results was in the vicinity of northern Yucca Flat and the area around the Climax Mine (fig. 1). Reasonable similarities between the regional and site-scale HFM were observed for the altitudes of the tops of volcanic-rock HGUs and the LCA in Yucca Flat and Frenchman Flat. However, in the vicinity of northern Yucca Flat, the DVRFS v. 1.0 HFM was constructed with the LCA extending northward continuously from Yucca Flat into Emigrant Valley, whereas the construction of the site-scale HFMs used a discontinuous LCA in northern Yucca Flat. The UGTA Phase I regional HFM (IT Corporation, 1996a; IT Corporation, 1996b) used a similar configuration of the LCA, but incorporated some changes that limited the extent of the LCA. Both the DVRFS v. 1.0 and UGTA Phase I numerical models simulated greater amounts of groundwater flow from Emigrant Valley toward Yucca Flat through the LCA than previously estimated (on the basis of estimates from the Nevada Division of Water Resources, 1972; Winograd and Thordarson, 1975; Harrill and others, 1988; and Pohlmann and Ye, 2012).

In northern Yucca Flat, altitudes of the tops of HGUs ICU, $\mathrm{XCU}$, and LCCU of the regional HFM were increased in order to match altitudes of the related units in the Rainier MesaShoshone Mountain (National Security Technologies, LLC, 2007) and Yucca Flat-Climax Mine (Bechtel Nevada, 2006) site-scale models. Figure 4 shows the extent of modification to grid cells for the LCCU. Adjustments to HGUs XCU and ICCU involved the same grid cells. These modifications to HGUs resulted in a thinning, but not elimination, of the LCA to the west and southwest of the Climax stock (fig. 4). 


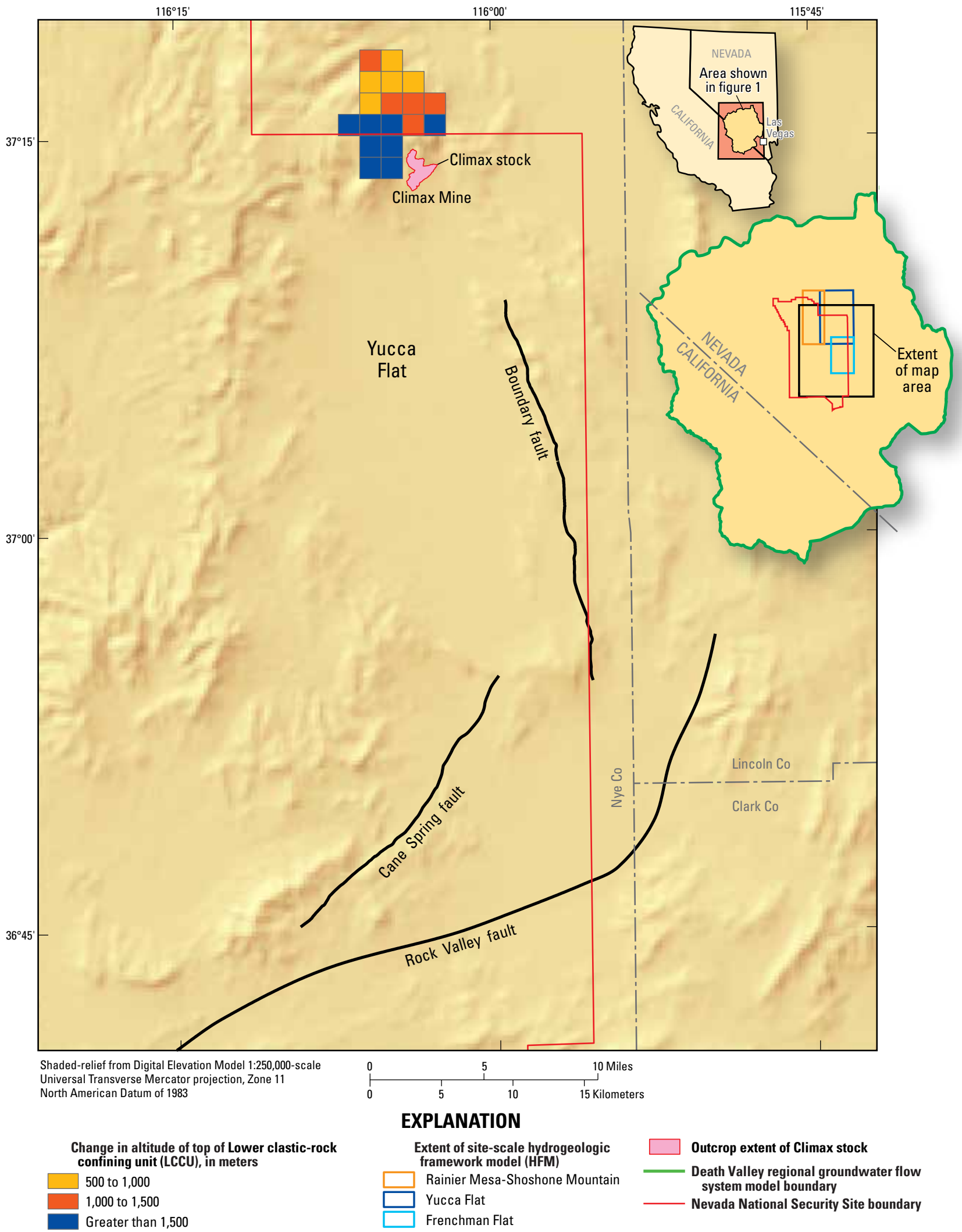

Figure 4. Revisions of the hydrogeologic framework model in the vicinity of Yucca Flat. 


\section{Representation of Lithologic and Textural Variations in the Amargosa Desert}

The Cenozoic basin-fill deposits in the vicinity of the Amargosa Desert were represented within the DVRFS v. 1.0 HFM (Faunt, Sweetkind, and Belcher, 2010) by HGUs that included the volcanic- and sedimentary-rock units (VSU), the limestone aquifer (LA), and four shallow HGUs (OAA, OACU, YAA, YACU) that represented the alluvial units. In certain areas, the altitude of contacts between basin-fill HGUs was based on geometric rules, not on geologically-interpreted subsurface contacts (Faunt, Sweetkind, and Belcher, 2010, p. 181, 185). The spatial variability in material properties of basin-fill HGUs was generalized as a series of horizontal hydraulic conductivity zones (Faunt, Blainey, and others, 2010) based on limited published data of subsurface variations of sediment type (Oatfield and Czarnecki, 1989, 1991;

Sweetkind, Belcher, and others, 2010).

Lithologic data from selected boreholes from the Amargosa Desert and surrounding areas were recently compiled, and a subset of those data used to define the subsurface 3D lithologic heterogeneity of the principal HGUs (Taylor and Sweetkind, 2014). The DVRFS v. 1.0 HFM (Faunt, Sweetkind, and Belcher, 2010) was revised by incorporating the results of the new geologically-based representation of the shallow basin fill (Taylor and Sweetkind, 2014).

Lithologic data from 466 selected boreholes from the Amargosa Desert and surrounding areas and from exposed sections of Neogene strata from the basin margins (Taylor and Sweetkind, 2014, appendix 1) were used to define the subsurface lithologic heterogeneity of the Amargosa Desert area. Lithologic descriptors from the drill holes in the Amargosa Desert were standardized into a common lithologic nomenclature of 31 classes to facilitate interpretation (table 2). Using the methodology described in Taylor and Sweetkind (2014), the 31 interpreted lithologic classes derived from the borehole data were used to construct a 3D volumetric model of lithologic variations within the basin by interpolating data between boreholes using a nearest-neighbor 3D-gridding process. Cell dimensions for the volumetric modeling were $500 \mathrm{~m}$ in the horizontal dimension and $10 \mathrm{~m}$ in the vertical dimension. The 3D-gridding is a cell-based modeling approach where, for each 10-m vertical interval, cell nodes are assigned one of the 31 lithologic classes based on the lithology present at that elevation in the closest borehole (Taylor and Sweetkind, 2014).

Textural data, such as grain size, sorting, and bedding characteristics, form a geologic basis for creating homogeneous zones of hydraulic properties for unconsolidated sediments within a numerical groundwater-flow model (Burow and others, 2004; Faunt, Blainey, and others, 2010). Previous studies of basin-fill sediments indicate that sediment grain size, tabulated as percentage of coarse-grained texture, is useful as the primary variable in the textural analysis (Phillips and Belitz, 1991; Burow and others, 2004; Faunt, 2009; Sweetkind and others, 2013). The 31 interpreted lithologic classes derived from the borehole data in the Amargosa Desert were coded in terms of grain size and sorting parameters to spatially delineate initial zones of hydraulic properties for the numerical model (table 2). Lithologic classes were assigned a relative permeability on a qualitative scale (high to low) on the basis of available aquifer tests in these materials and available specific-capacity data from wells (Dudley and Larson, 1976; Belcher and others, 2001) (table 2). Using the methodology described in Faunt (2009), grain size and sorting were coded by using simple binary descriptors; coarse-grained deposits were given a grain-size code of 1 , fine-grained deposits were assigned a code of 0 . Similarly, well-sorted deposits were assigned a sorting code of 1 and poorly sorted deposits were assigned a code of 0 (table 2). Coarse-grained deposits were dominated by gravel and sand-size clasts with no clay matrix; all other lithology classes were considered fine grained. Even units that had a considerable fraction of large clasts were classified as fine grained if the clasts tended to be suspended in a fine-grained matrix (table 2). Grain size and sorting were then combined to form four principal texture classes for the sedimentary deposits: well sorted, coarse (texture class 1); well sorted, fine (class 2); poorly sorted, coarse (class 3); and poorly sorted, fine (class 4 ). Three additional texture classes were created for those lithologic classes not amenable to grain size and sorting descriptors: volcanic (texture class 5), Tertiary carbonate (class 6), and other (class 7). The resulting textural classes form the basis of the zonation scheme for hydraulic parameters (horizontal hydraulic conductivity, vertical hydraulic conductivity, and storage) used in the numerical flow model.

For use in the DVRFS v. 2.0 HFM, the 500-m discretization of the 3D volumetric lithologic model of the Amargosa Desert area (Taylor and Sweetkind, 2014) was generalized to the 1,500-m HFM model cells, and the 10-m thick extrapolated lithology layers were distributed to the flow model layers. Cell values from the 3D volumetric lithologic model (Taylor and Sweetkind, 2014) were exported as an ASCII array of points defined by 3D Cartesian coordinate values $(\mathrm{X}, \mathrm{Y}, \mathrm{Z})$ and lithologic class information using a utility in the geological modeling software. This array of points was then re-sampled to the HFM grid. Lithologic variability of the basin-fill sediments is far greater in the vertical dimension than in the $\mathrm{X}-\mathrm{Y}$ dimension, so re-sampling in the $\mathrm{X}-\mathrm{Y}$ dimension was accomplished by sampling every third value to populate a cell with a lithology class. The effect of this sampling is to slightly shift the spatial extent of certain lithologies, while retaining the lithologic class. This eliminates a sampling scheme where, for instance, "sand" and "clay" are averaged over a cell. The 10-m vertical resolution of the lithologic model was preserved.

Alluvial HGUs above the lower VSU were removed and replaced with flat, 10-m thick model layers that matched the vertical layering of the $3 \mathrm{D}$ volumetric lithologic model of the Amargosa Desert area (Taylor and Sweetkind, 2014). Model layers were added to the HFM to fill the volumetric between the lower VSU and land surface. These layers were clipped below by the top of the lower VSU and above by land surface. 
Table 2. Lithologic and textural classes and inferred relative permeability for the Amargosa Desert basin-fill deposits.

[TGC, Tertiary groundwater carbonate; - , no data]

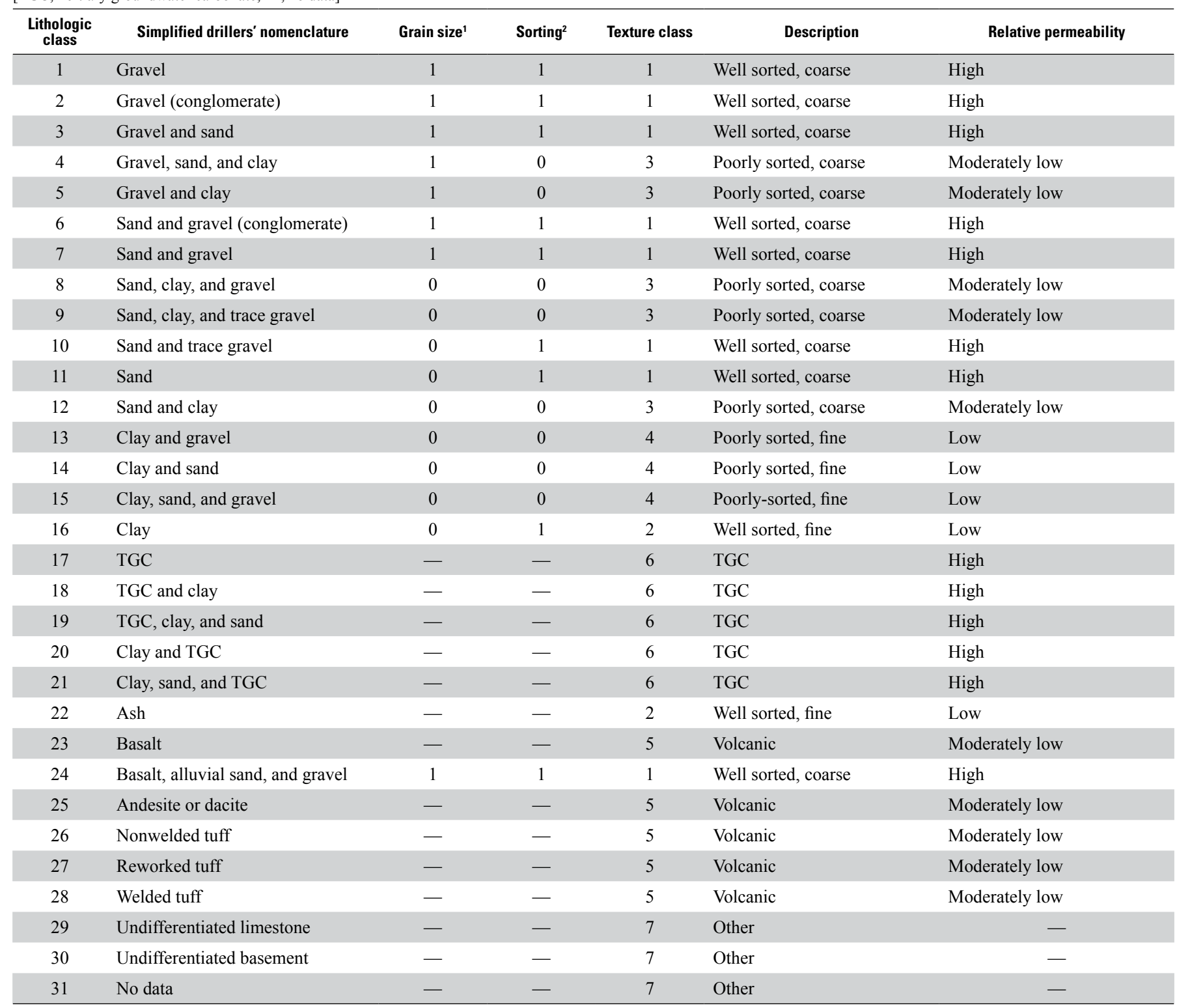

${ }^{1}$ Coarse-grained units are given a grain-size parameter of 1 ; fine-grained units are given a 0 .

${ }^{2}$ Well-sorted units are given a sorting parameter of 1 ; poorly sorted units, in particular units with a clay matrix, are given a 0 .

In areas of topographic relief or places where the lower VSU was elevated above land surface, some areas of the layers had thicknesses between 0 and $10 \mathrm{~m}$. Ninety-five additional layers were needed to define the additional lithologic detail for the basin-fill units in the Amargosa Desert. These 95 altitudebased layers were then populated with values representing the 31 textural classes sampled from the 3D model (table 2). The inclusion of these 95 layers representing $10-\mathrm{m}$ increments of the alluvial basin fill resulted in 122 HGUs in the HFM.

\section{Revisions to Fault Representations in the Hydrogeologic Framework Model and Flow Model}

The site-scale HFMs portray many more faults than the DVRFS HFM. This difference results from both the greater geologic detail portrayed in the site-scale HFMs and also from differing methods of HFM construction, where the site-scale HFMs emphasize fault-bounded blocks. A comparison was made between the regional HFM and the site-scale HFMs to ensure that faults important for site-scale groundwater flow were incorporated, where possible, in the regional HFM. The 
comparison used a regional-scale perspective, where faults with large-magnitude displacement or those faults that affected the regional flow field were primarily considered. The 1,500-m cell size in the regional HFM limited the amount of fault detail portrayed at the regional scale.

The important structures within the site-scale HFMs of the NNSS and vicinity are caldera boundaries, the Yucca-Rock Valley, Cane Spring fault and Bare Mountain faults, and the Belted Range and CP thrusts. All of these faults were discussed in detail in Potter and others (2002) and were already present in the regional HFM (Faunt, Sweetkind, and Belcher, 2010). The location and offset of these faults are reasonably similar between the regional HFM and the site-scale HFMs. Only one additional fault from the site-scale HFMs, the Boundary fault on the east side of Yucca Flat, was added to the regional HFM as a result of the comparison.

The 38 faults included in the DVRFS v. 1.0 model (Faunt, Blainey, and others, 2010) as horizontal-flow barriers (HFBs) using the Horizontal-Flow Barrier package are included in DVRFS v. 2.0. Three additional faults from the CAU area (Rock Valley, Cane Springs, and the Boundary faults on the east edge of Yucca Flat [fig. 5]), not previously considered as HFBs in DVRFS v. 1.0, were added to DVRFS 2.0 to improve consistency between the regional flow model with modeling activities by the NNSS. Like the previous model structures, the three new features were inserted as HFBs. However, these three features included zones of enhanced hydraulic conductivity parallel to the fault, consistent with observed hydrologic conditions and the permeability structure of fault zones studied elsewhere (Evans and others, 1997; Rawling and others, 2001) that were simulated by adjusting the horizontal hydraulic conductivity in cells adjacent to the HFB. The Boundary faults are roughly adjacent to the water-level trough in eastern Yucca Flat in the LCA (Fenelon and others, 2010). For the other two faults, the combined barrier/conduit approach matches the conceptualization by Fenelon and others (2010) where flow moves parallel to the faults to the area south and southwest of $\mathrm{CP}$ basin and Frenchman Flat.

\section{Hydrologic Data Updates}

As part of the development of DVRFS v. 2.0, several hydrologic data sets were revised to extend these input data sets through the new simulation period of the numerical flow model (through 2003) to represent the process being simulated more accurately. The extension of the simulation period through 2003 is largely constrained by the pumpage dataset of Moreo and Justet (2008). This pumping data update only extended through 2003 and thus, limited the transient simulation period to this time. These updates were for the following input data sets:

- pumpage from Moreo and Justet (2008)

- hydraulic heads (Pavelko, 2010)

- recharge from precipitation (Faunt, Blainey, and others, 2010)

In addition, an initial top surface for the numerical flow model was developed from an update to the estimated idealized potentiometric surface from DVRFS v. 1.0 (D'Agnese and others, 1998) using updated hydraulic heads from Pavelko (2010) and Bedinger and Harrill (2010), and spring location data from Bedinger and Harrill (2010).

\section{Pumping and Irrigation Return Flows}

In DVRFS v. 1.0, pumping data were compiled and interpreted to create a continuous record of pumping from 1913 through 1998 (Moreo and others, 2003). Withdrawal locations and depth of production intervals were estimated and associated errors were reported for 9,300 wells. Withdrawals were grouped into three categories: (1) mining, public supply, and commercial water use, (2) domestic water use, and (3) irrigation water use.

Since the release of Moreo and others (2003), pumping has increased in areas directly south and to the southeast of the NNSS (Amargosa Desert and Pahrump Valley) primarily in response to population growth in these areas. To evaluate the impact of increased water withdrawals on local and regional flows using the DVRFS v. 2.0 model, these pumpage estimates were revised to include new data, extending the pumping record another 5 years, from 1999 through 2003, and the method used to estimate pumping was slightly revised (Moreo and Justet, 2008).

The updated pumping inputs included

- only points of groundwater withdrawal (wells) within the currently defined DVRFS boundary (fig. 1),

- pumping in calendar years 1999 through 2003, and

- minor changes in how rates of evapotranspiration (ET) were estimated in order to determine crop coefficients, a key component of estimates of water usage for agriculture. 


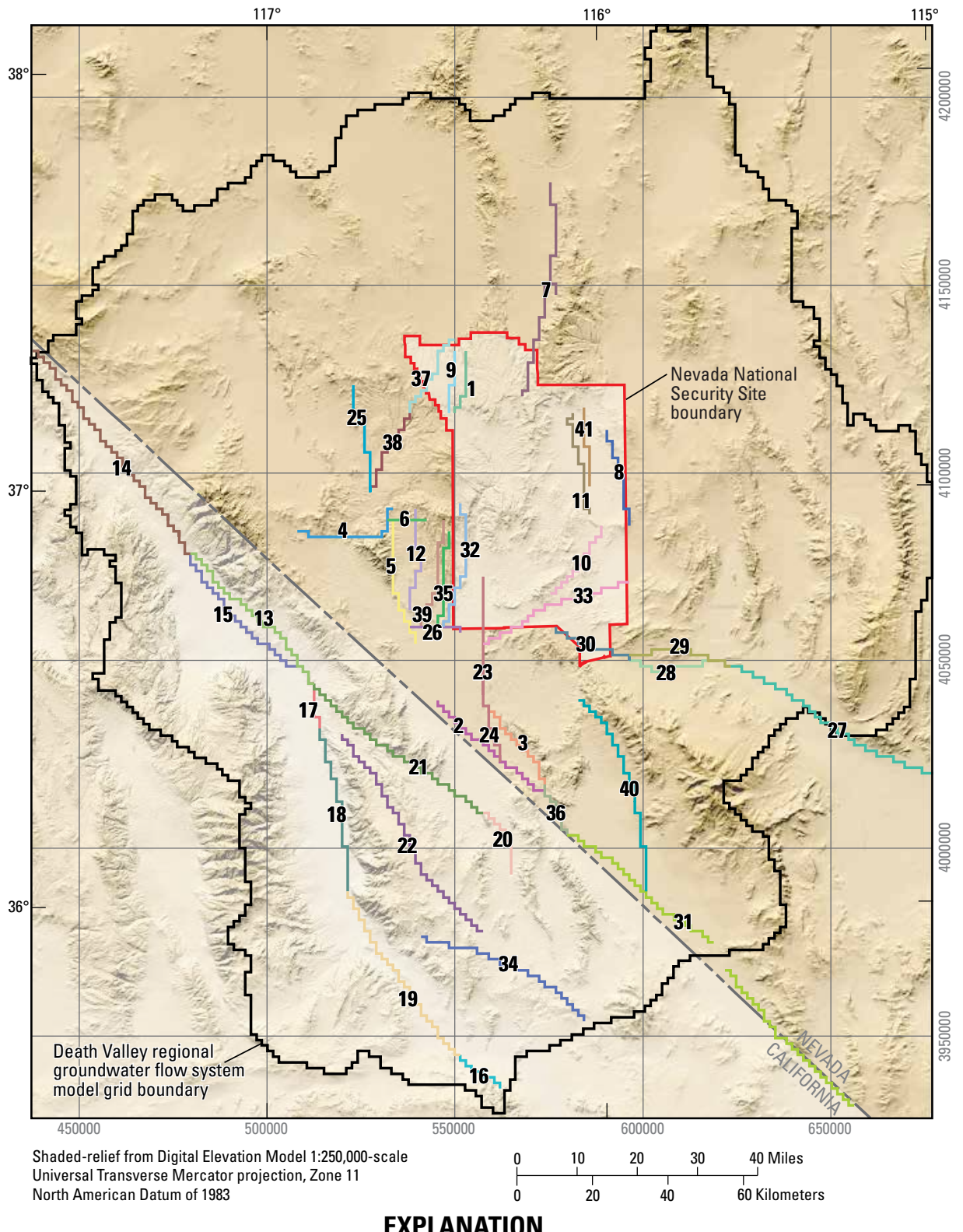

\section{EXPLANATION}

Hydrogeologic structures simulated as horizontal-flow barriers (Parameter name in parentheses

-1 - Alamandro fault (B_ALAMANDR)

2-Amargosa River fault (B_AMARGOSA)

3-Ash Meadows fault (B ASHMEADO)

-4-Bare Mountain detachment (B_BAREMT_D)

5 - Bare Mountain fault (B_BAREMT_F)

-6- Bare Mountain, Tram segment (B_BAREMT_T)

7- Belted Range fault (B_BELTEDRN)

-8- Boundary fault (B_BOUNDARY)

9-Box Car fault (B_BOX_CAR)

10-Cane Spring fault (B_CANE_SPR)

-11-Carpetbag fault (B_CARPET_B)

12-Crater Flat fault (B_CRATERFL)

13- Keane Wonder segment of Death Valley fault zone (B_DV_KW)

-14- Northern Death Valley-Furnace Creek fault zone (B_DV_N)

-15- Northern Death Valley-Furnace Creek fault zone, segment 2 (B_DV_N2)
-16- Death Valley fault zone, Saratoga segment (B_DV_SARAT)

17- Death Valley fault zone, Furnace Creek Ranch segment ( $B$ DVFC FCR)

-18 - Central part of Death Valley fault zone (B_DVFCFZ_C)

19 - Southern part of Death Valley fault zone (B_DVFCFZ_S)

20 - Eagle Mountain segment of Furnace Creek fault zone (B EAGLE MT)

-21- Furnace Creek fault zone (B_FCFZ)

-22-Grandview fault (B_GRANDVIE)

23 - Northern part of Gravity fault (B_GRAV_N)

24-Southern part of Gravity fault (B_GRAV_S)

25- Hogback fault (B_HOGBACK)

26- Highway 95 fault (B_HWY95)

27- Eastern part of main trace of Las Vegas Valley shear zone (B_LVVSZ_1)

28 - Southern part of main trace of Las Vegas Valley shear zone (B_LVVSZ_12)
29- Indian Springs splay of the Las Vegas Valley shear zone (B_LVVSZ_IS)

30- Western part of main trace of Las Vegas Valley shear zone (B_LVVSZ_IW)

31- Pahrump Valley part of Pahrump-Stewart Valley fault zone (B_PAHRUMP)

32 - Paintbrush Canyon fault (B_PAINTBRC)

33- Rock Valley fault (B_ROCK_VAL)

34-Sheephead fault (B_SHEEPHEA)

35- Solitario Canyon fault (B_SOLITARI)

36- Stewart Valley part of Pahrump-Stewart Valley fault zone (B_STEWART)

37 - Thirsty Canyon lineament (B_TC_LINE)

-38- Southern part of Thirsty Canyon lineament (B_TC_LINES)

39- Windy Wash fault (B_WINDYWAS)

-40 - West Spring Mountains fault (B_WSPRINGM)

-41- Yucca fault (B_Yucca_FL)

Figure 5. Location of hydrogeologic structures acting as horizontal-flow barriers in the Death Valley regional groundwater flow system v. 2.0 model. 
Pumpage is a relatively small stress on the DVRFS compared to the overall flow through the regional flow system. Prior to the late 1950s, the differences in the magnitude of pumping between those reported by Moreo and others (2003) and those of Moreo and Justet (2008) were less than 1 percent (fig. 6). After 1950, the pumping reported by Moreo and Justet (2008) was somewhat less; the difference ranged from 8 percent $\left(4,000 \mathrm{~m}^{3}\right.$ or $\left.1,400 \mathrm{ac}-\mathrm{ft}\right)$ for the $1960 \mathrm{~s}$ to 27 percent $\left(20,905 \mathrm{~m}^{3}\right.$ or $7,100 \mathrm{ac}-\mathrm{ft}$ ) for the early $1990 \mathrm{~s}$ (Moreo and Justet, 2008) (fig. 6).

Most groundwater withdrawals in the DVRFS have been for irrigation (fig. 6). In 2003 for example, total groundwater withdrawal was estimated at about $71,000,000 \mathrm{~m}^{3}$ (57,500 ac-ft) (Moreo and Justet, 2008). Of this amount, $49,000,000 \mathrm{~m}^{3}(40,000 \mathrm{ac}-\mathrm{ft})$ were withdrawn for irrigation use, $9,200,000 \mathrm{~m}^{3}$ (7,500 ac-ft) for domestic use, and $13,000,000 \mathrm{~m}^{3}(10,400 \mathrm{ac}-\mathrm{ft})$ for public supply, commercial, and mining uses (Moreo and others, 2008). Since 1998 there has been a marked decrease in irrigation use and an increase in commercial, public supply, and domestic uses (fig. 6). This trend is likely the result of agricultural fields being taken out of production (approximately $4 \mathrm{~km}^{2}$ or 1,000 acres) for planned housing developments in Pahrump Valley and for declining agricultural water use in the Amargosa Desert. Between 1999 and 2003, domestic, public supply, and commercial uses have increased throughout the region at a rate greater than the decrease in irrigation. In addition, there has been a decline in mining-related water use since 1998, mainly due to the closure of a large mine in the Amargosa Desert.

Part of the pumped groundwater returns to the regional groundwater system through infiltration of excess irrigation, lawn water, and (or) septic tank wastewater (Faunt, Blainey, and others, 2010; San Juan and others, 2010). Moreo and others (2003) and Moreo and Justet (2008) did not adjust their estimates of annual pumpage for water potentially returned to the flow system through subsequent infiltration, and the magnitude and timing of these return flows were not precisely quantified. Moreo and others (2003) did, however, develop a method to provide general estimates of return flow. Many difficulties are associated with estimating return flows, including the uncertainties associated with pumpage, hydraulic properties of unsaturated zone sediments, and the delineation of actual areas where water is or was returned to the aquifer. For each withdrawal point, return flow was estimated by Moreo and others (2003) to be 20 percent of the estimated annual pumpage, lagged by 7 years. These values formed the initial values for return flow and lag time in the numerical model. Return flow is applied to the uppermost layer of the flow model.

\section{Hydraulic Heads}

The water-level database for DVRFS v. 1.0 included hydraulic-head measurements from 1913 through 1998 (San Juan and others, 2010). For the DVRFS v. 2.0 model, the database was updated to include additional wells, and the data period was extended through 2007 (Pavelko, 2010). The update of the database followed the methods established by San Juan and others (2010). Wells drilled since 1998 and previously existing wells not included in the original compilation were added to the database (Pavelko, 2010). Although the database contains values beyond 2003, these values were not used in the simulation because of the constraint imposed on the simulation period by the pumping database.

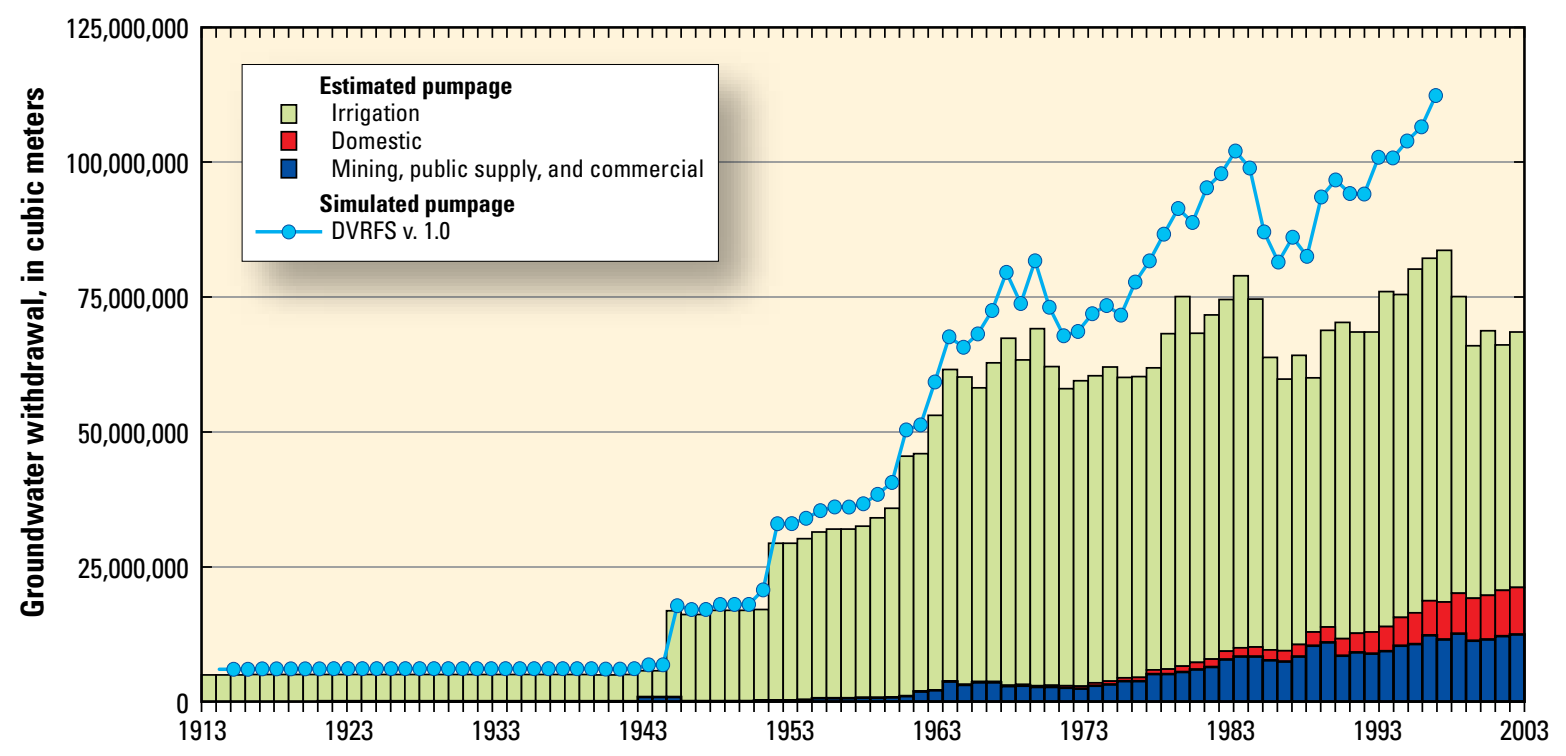

Figure 6. Annual estimates of groundwater withdrawal from the Death Valley regional groundwater flow system (DVRFS) by general water-use type, 1913-2003, (Moreo and Justet, 2008) and used in the DVRFS v. 2.0 model. For comparison, total simulated groundwater withdrawal from DVRFS v. 1.0 is shown (Moreo and others, 2003; Faunt, Blainey, and others, 2010). 
The updated water-level database for DVRFS v. 2.0 includes (1) only hydraulic-head measurements within the DVRFS boundary (fig. 1) as defined by Belcher and others (2010), and (2) an extension to include measurements made through 2007. No uncertainty estimates for the hydraulichead measurements were included in the database. More than 54,000 water levels measured from 1907 to 2007 in about 1,800 wells were compiled, analyzed, and characterized for the updated water-level database (fig. 7). Most wells have less than $15 \mathrm{~m}$ of drawdown. Wells having drawdowns greater than $15 \mathrm{~m}$ typically are in areas of concentrated irrigation use, primarily in the Amargosa Desert and Pahrump and Penoyer Valleys (Pavelko, 2010).

\section{Recharge from Precipitation}

In the DVRFS, recharge from precipitation occurs mostly from direct infiltration of precipitation on high mountain ranges, infiltration of runoff at the base of the mountain ranges, and in alluvial fans or channels (San Juan and others, 2010). Hevesi and others (2003) estimated potential recharge by using an infiltration model, INFILv3, which computed potential recharge that varied spatially but had no temporal variation. In DVRFS v. 1.0, recharge was considered to be constant during the entire transient simulation period because it was assumed that climate variability was minimal during the period of simulation and that year to year variability would not have an appreciable effect on overall movement of groundwater within the flow system. Net infiltration from Hevesi and others (2003), used in DVRFS v 1.0, was an annual average for the period of record (1950-99). In order to improve the representation of recharge in DVRFS v. 2.0, the amount of recharge was varied through time to better reflect climate variability.

In order to vary recharge through time, an annual multiplier for the average recharge was developed by using precipitation variability during the simulation period (1913 through 2003). The historical annual 4-km Parameter-elevation Regressions on Independent Slopes Model (PRISM) precipitation values (PRISM, 2008) were interpolated to the model grid for each year of the numerical flow model simulation period (1913 through 2003) to obtain a spatially varying annual precipitation value for each model grid cell. From these model-based precipitation arrays, the average annual value and the yearly deviation from the annual average were calculated for each model cell. This annual deviation from average was used as a multiplier to adjust the modeled, spatially varying recharge (Hevesi and others, 2003) for each annual stress period. Figure 8 presents the average annual recharge used in the model with graphs of temporally varying recharge for a selected grid node in the Spring Mountains, Sheep Range, and Pahute Mesa.

\section{Modification of the Estimated Regional Potentiometric Surface}

An estimated regional potentiometric surface was used to represent the initial top surface in the DVRFS v. 1.0 model (D’Agnese and others, 1998). Domenico and Schwartz (1990, p. 255-259) suggest that a regional potentiometric surface in intensely fractured, mountainous regions (such as the DVRFS) can be interpreted as a series of semi-continuous, free surfaces connected between basins by steep hydraulic gradients. The resulting water-level configuration is, therefore, interpreted as a relatively flat surface in each subbasin connected by zones of steep hydraulic gradients in mountain blocks of comparatively low permeability. The water-level contours are not intended to represent the water table within a specific aquifer, but rather a coherent surface from which to generalize the regional occurrence and movement of groundwater across HGUs from steady-state water levels.

For the purposes of the steady-state stress period of DVRFS v. 2.0, the groundwater system is assumed to be in hydraulic equilibrium under pre-development (pre-1913) conditions. The water levels used to produce this map are likely a mixture of both confined and unconfined water levels, especially in the bedrock units. Thus, the map (pl. 1) represents a combination of potentiometric surfaces distributed across the HGUs of the region, ultimately representing the top of the pre-development regional aquifer system. Because DVRFS v. 2.0 simulated the DVRFS as confined, the idealized potentiometric surface represented in plate 1 was used as the top of layer 1 initially.

The idealized regional potentiometric surface was constructed by using the locations and altitudes of regional springs, groundwater levels from wells and boreholes, lakes, ponds, recharge and discharge areas, the regional hydrogeology, and topography using GIS, automated interpolation techniques, and manual editing to incorporate "soft" data and tacit knowledge (D’Agnese and others, 1998). The map was constructed by using the control-point data without consideration for either the depth of well penetration or the geologic formations (or HGUs) penetrated by the wells. The estimated idealized potentiometric surface map developed for DVRFS v. 2.0 does not distinguish wells screened in the basin fill from wells screened in the bedrock.

The estimated idealized potentiometric surface used in DVRFS v. 1.0 was revised for use in constructing the initial upper surface of the DVRFS v. 2.0 model (pl. 1). The updated potentiometric map (pl. 1) is based on the estimated steadystate potentiometric surface of D'Agnese and others (1998), but extends throughout the entire DVRFS model domain (fig. 1), and was modified to include new steady-state waterlevel data (Pavelko, 2010). The updated surface implicitly respects all constraints of the original surface and is intended for use as the initial top surface (starting heads) of the flow model. The top surface of the model was iteratively set to the heads of layer 1 from the previous run during calibration. 


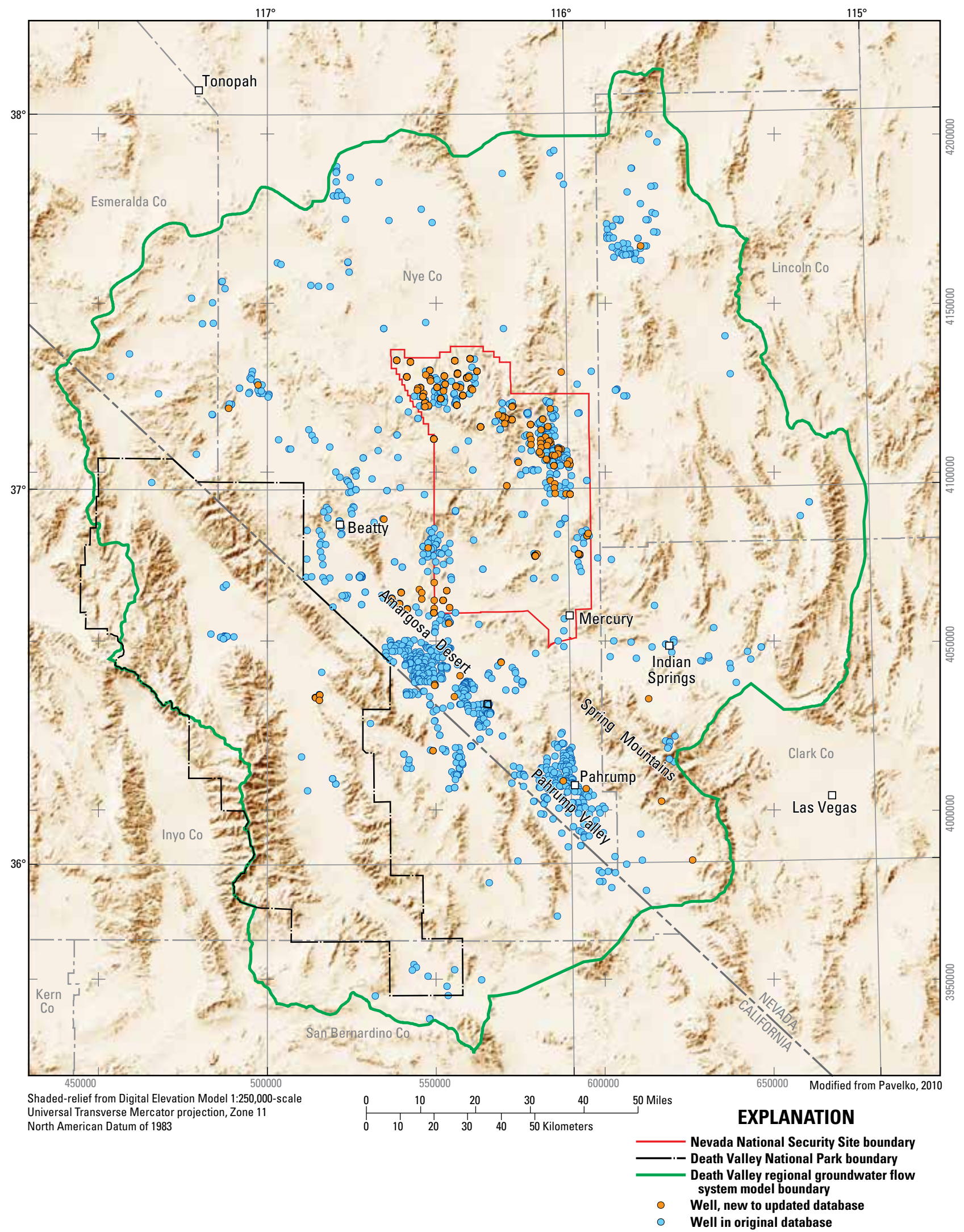

Figure 7. Areal distribution of wells included in the original and updated water-level databases for the Death Valley regional groundwater flow system, Nevada and California. 


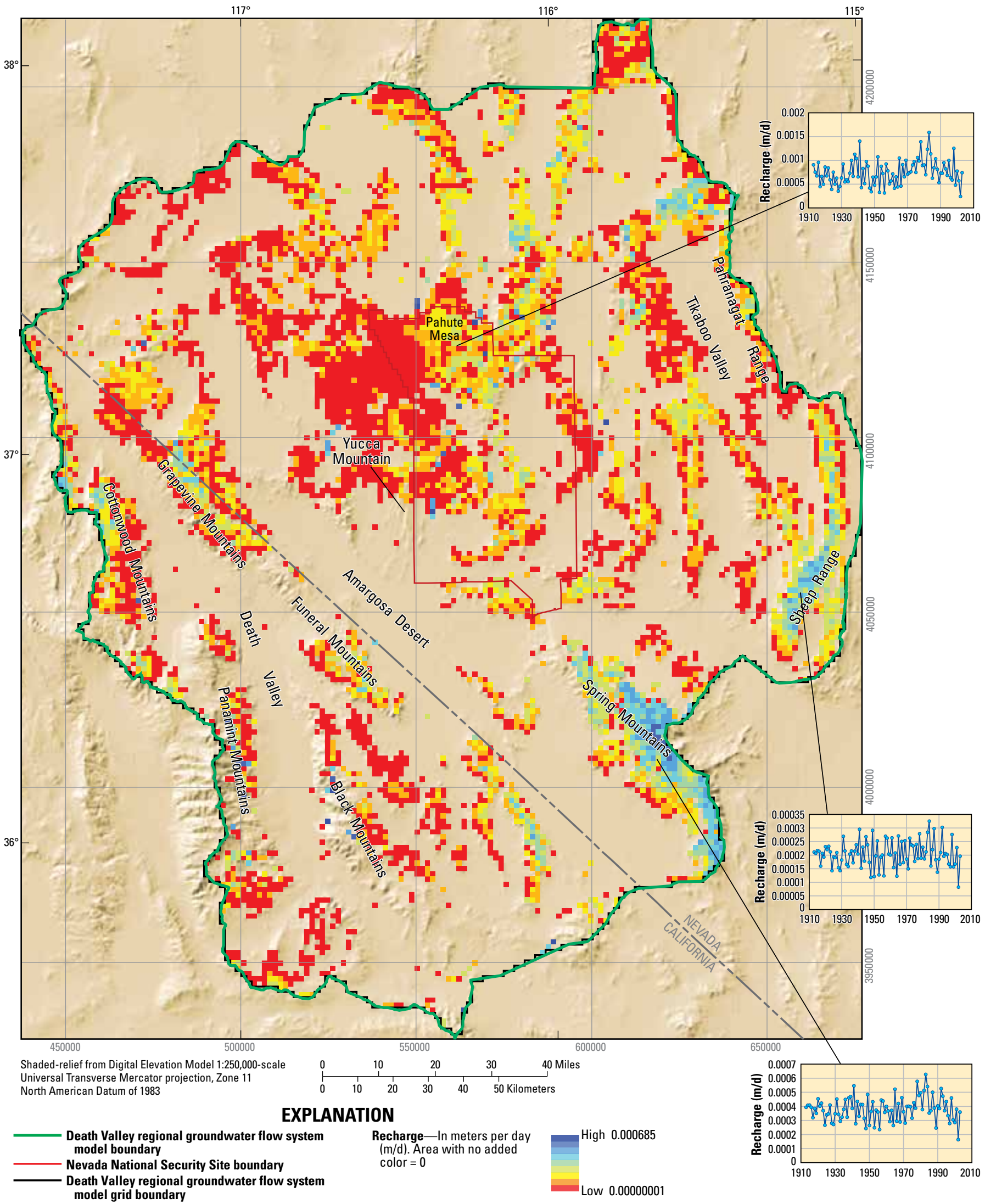

Figure 8. Average annual recharge simulated for the Death Valley regional groundwater flow system model, with graphs of temporally varying recharge for selected grid cells in the Spring Mountains, Sheep Range, and Pahute Mesa. 
Construction of the potentiometric map began with the potentiometric contours of D'Agnese and others (1998), which were assumed to be accurate and were only modified in areas where new data points conflicted with the original interpretation. To update this surface, water levels that are flagged as Steady State-Regional Scale in Pavelko (2010) were compiled and compared to the D'Agnese and others (1998) contours.

Regional spring altitudes (essentially land surface) were used qualitatively to assess the revised contours, but were not used explicitly in the contouring. Springs were considered to represent the regional flow system if they had temperatures ranging from $24{ }^{\circ} \mathrm{C}$ to $35^{\circ} \mathrm{C}$ and steady, large-volume discharges of greater than about 1,500 cubic meters per day $\left(\mathrm{m}^{3} / \mathrm{d}\right)(450$ acre-feet per year [acre-ft/yr]) from valley floors or margins (Winograd and Thordarson, 1975).

The regional hydraulic heads were initially contoured by using a computer-contouring routine. In places where these contours contradicted basic hydrologic principles, such as cross-cutting mountains or rising above land surface, the contours were manually edited to be below land surface. In areas with new data and areas where the updated contours differed from the original contours of D'Agnese and others (1998), the contours were manually edited to preserve as much as possible the shape of the original surface.

Although not evident on regional potentiometric-surface maps, for the DVRFS potentiometric-surface map (pl. 1) it is assumed that downward vertical gradients typically exist beneath recharge areas in the mountain blocks or along the valley margins, and that upward vertical gradients exist in valley bottom discharge areas. Similar to the original estimated potentiometric surface (D'Agnese and others, 1998), the dominant features of the updated surface include water-level mounds, depressions and troughs, and steep hydraulic gradients. These features generally are controlled by topography, lithology, and geologic structure (Winograd and Thordarson, 1975; Carr, 1984; Faunt, 1997).

The resultant surface contours display some minor differences in the shape and location of smaller and less prominent water-level mounds and troughs when compared to D'Agnese and others (1998). Mounds are still present in the Rainier Mesa and Shoshone Mountain areas, but they are lower, broader, and shifted slightly to the west. The Black Mountain mound, centered over Greenwater Valley, is no longer present. All other mounds delineated in D'Agnese and others (1998) are still very similar except for generally being lower in altitude, reflecting the revised interpretation.
Several features are present on the revised potentiometric surface that were not well defined in D'Agnese and others (1998) due to their position on the edge of the study area boundary. The trough at Stonewall Pass and the depression at Sarcobatus Flat are still present but they generally are broader and higher in altitude. The Emigrant Valley trough is still present but generally is broader and lower in altitude. In addition, an areally large, relatively flat potentiometric surface at Sand Spring Valley (Penoyer Valley) and mounds in the Kawich and Sheep Ranges differ from the estimated potentiometric map of D'Agnese and others (1998).

The construction of the idealized regional potentiometric map has both temporal and spatial limitations. With respect to spatial limitations, there are no water-level data for great parts of the DVRFS; there are clusters of data at Pahrump Valley, Amargosa Desert, the NNSS, and Penoyer Valley. In the eastern, northern, and southwestern parts of the DVRFS there is a paucity of data. There are very few wells outside the NNSS that occur at depth. Most of the data for the LCA is from springs, with the land-surface altitude of the spring being used as a proxy for the head at that location. Furthermore, there are no pre-development, steady-state water levels over large parts of the DVRFS. Recent data that appear to reflect non-pumping conditions were used as a proxy for pre-development (prior to 1913) water levels. This use of recent water-level data assumes that areas with little or no groundwater development have an insignificant impact on the regional groundwater system. No analysis was done to assess if the pre-development system was in a true steady state, as for example, if it were still affected by a slow transient hydraulic recovery from wetter periods during the Pleistocene Epoch. 


\section{Numerical Model Construction and Revisions}

In the DVRFS v. 2.0 model, groundwater flow is simulated by using the MODFLOW-2005 code (Harbaugh, 2005), producing a model very similar to DVRFS v. 1.0 (Faunt, Blainey, and others, 2010). The north-south-oriented grid is based on a uniform finite-difference grid with 194 rows, 160 columns, and 16 layers. The cells are uniform at $1,500 \mathrm{~m}$ on each side (fig. 9) and vary in thickness from 50 to more than $300 \mathrm{~m}$. With the exception of model layer 1 , which has some thicker parts locally, model layer thickness generally increases with depth. This allows greater resolution at the top of the flow model where more hydrologic and geologic data are available. Inflow or outflow across the model boundary is simulated by constant heads specified in the cells along the boundary that are at or below a regional potentiometric surface as defined by Bedinger and Harrill (2010) (fig. 10). This potentiometric surface and the derived constant-head boundary values conceptually represent the hydraulic head in the deep flow system (the carbonate-rock aquifer). The transient simulation begins with a steady-state pre-pumping condition (prior to 1913).

Recharge from precipitation is simulated by using the $\mathrm{RCH}$ package, and natural discharge areas (springs and ET areas) are simulated as drains using the Drain (DRN) package (fig. 10). Changes in recharge and discharge were simulated with annual stress periods. HGUs are the basis for assigning horizontal hydraulic conductivity, depth decay of hydraulic conductivity, vertical anisotropy, and storage characteristics to the cells of the model grid using the Hydrogeologic-Unit Flow (HUF) package (Anderman and Hill, 2000, 2003). Model input arrays also were used to account for variations in the hydraulic properties within HGUs by zonation.

\section{Numerical Code Selection}

Groundwater flow was simulated in the DVRFS v. 1.0 model by using MODFLOW-2000 (Harbaugh and others, 2000; Hill and others, 2000). The numerical modeling code used to simulate groundwater flow in the DVRFS v. 2.0 model is the USGS 3D groundwater flow model program MODFLOW-2005 with related packages (Harbaugh, 2005). MODFLOW-2005 is a block-centered finite-difference code in which a $3 \mathrm{D}$ groundwater flow system is divided into a sequence of layers of porous material organized in a horizontal grid or array. MODFLOW-2005, like MODFLOW-2000, is (1) capable of representing the 3D complexities of the groundwater flow system, (2) capable of simulating a variety of hydrologic conditions such as pumping and recharge, (3) capable of simulating steady-state and transient flow conditions, and (4) is well documented, freely available, well tested, and widely accepted. In the DVRFS v. 1.0 model, Faunt, Blainey, and others (2010) estimated the model parameters by using a parameter estimation approach incorporated within MODFLOW-2000. The parameter estimation software known as PEST was used to optimize parameter values during the calibration of DVRFS v. 2.0 (Doherty, 2010).

\section{Conversion from MODFLOW-2000 to MODFLOW-2005}

DVRFS v. 1.0 was initially converted to MODFLOW 2005 code and evaluated for consistency. Selected model input files were revised for MODFLOW-2005 formats and simulated flow budgets, residuals, and sensitivities generated in the MODFLOW-2000 version of DVRFS v. 1.0 were compared to the MODFLOW-2005 version. Most of the input files associated with MODFLOW-2000 may be used by MODFLOW-2005 directly without any changes. Examples include files for basic packages (BAS, DIS, OC, and ZON), internal flow packages (HUF2 and HFB), stress packages (CHD, DRN, RCH, and MNW1), and the solver package (PCG) (Hill, 1990; Hsieh and Freckleton, 1993; Anderman and Hill, 2000; Halford and Hanson, 2002; Harbaugh, 2005).

Six of the twenty initial input files were modified for the conversion to MODFLOW-2005. These files were as follows:

- name file (revised to remove deleted files and include new and updated file names).

- drain observations/prior-information, DROB file (number of observations/prior-information revised; output unit number added).

- hydraulic-head observations/prior-information, HOB file (unit number added for output).

- observations/prior-information, OBS file (not used).

- parameter values, PVAL file (DVRFS v. 1.0 values used).

- sensitivity values, SEN file (not used).

Although these changes were minor, translating input files can potentially introduce errors. Therefore, results from the DVRFS v. 1.0 model (Faunt, Blainey, and others, 2010) and the MODFLOW-2005 conversion were compared for the 1913 to 1998 period.

To evaluate the performance of the converted model, the MODFLOW-2000 DVRFS v. 1.0 model and the MODFLOW-2005 converted model were compared by using the same set of measured observations/prior-information and parameters. The comparison included evaluating simulated hydraulic head, flow at measured points and times, and boundary flow prior-information; cumulative volumetric flows; root mean square error (RMSE); and composite-scaled sensitivities (CSS), which indicate the information content of all the observations/prior-information for the estimation of a single parameter. The RMSE is a frequently used measure of the differences (residuals) between observed/prior-information values and values calculated by a model. The RMSE serves to aggregate the magnitudes of the errors in predictions for various times into a single measure of predictive power. The RMSE is a good measure of accuracy, but only to compare errors of different models for a particular variable and not between variables, as it is scale-dependent. Because it is only slightly dependent on the number of observations/prior-information, 


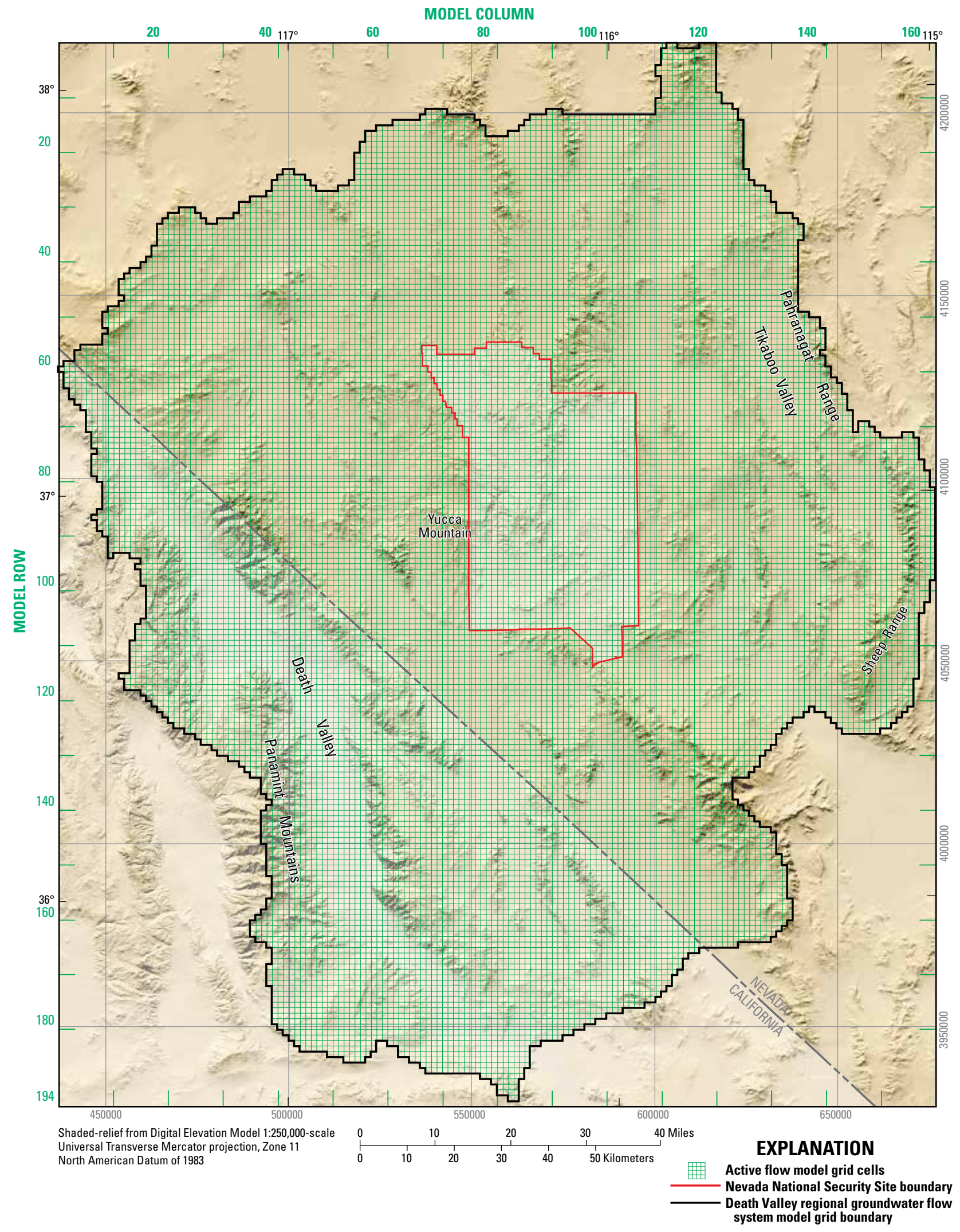

Figure 9. Model grid for the Death Valley regional groundwater flow system. 


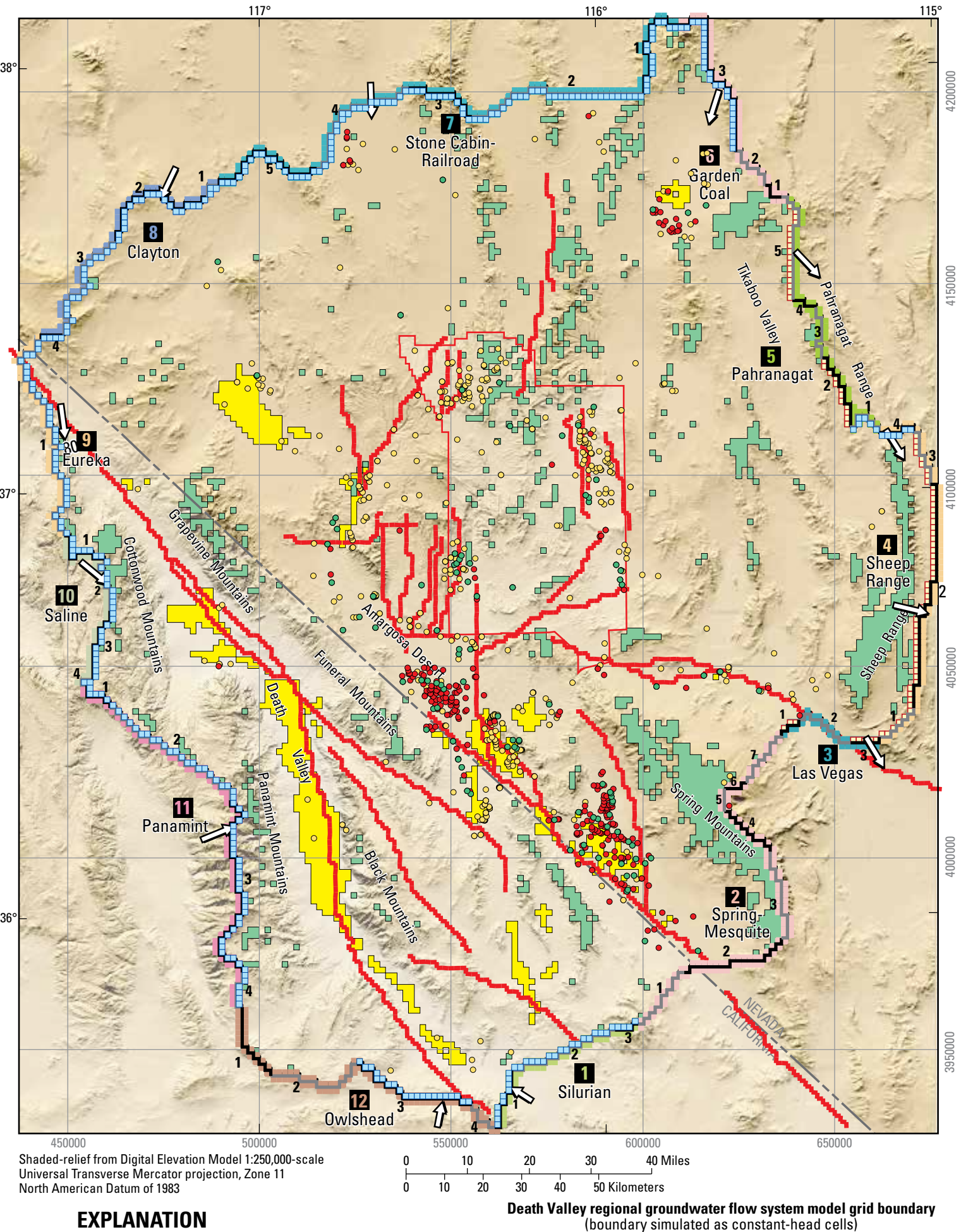

Simulated discharge areas (drains) Simulated major recharge areas

Simulated horizontal-flow barriers Nevada National Security Site boundary

Death Valley regional groundwater flow system model grid boundary Head and head-change observations

Steady-state (prepumped) stress period

Transient and steady-state stress periods

Transient (pumped) stress period
Colors shown with corresponding number indicate White and black lines with numbers in A segment Name along Death Valley regional indicate alternating segments within groundwater flow system model boundary Segment Name (for example, Garden Coal)

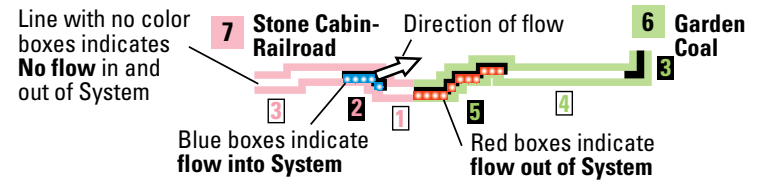

Figure 10. Simulated discharge areas, major recharge areas, and constant-head boundary flows for the Death Valley regional groundwater flow system. 
Table 3. Comparison of simulated cumulative volumetric flow budgets and root mean squared error for 1998 between the Death Valley regional groundwater flow system (DVRFS) v. 1.0 and the MODFLOW-2005 converted models.

[Volume in cubic meters; model simulations for MODFLOW-2005 converted DVRFS model include pumping changes and framework revisions; - , no data]

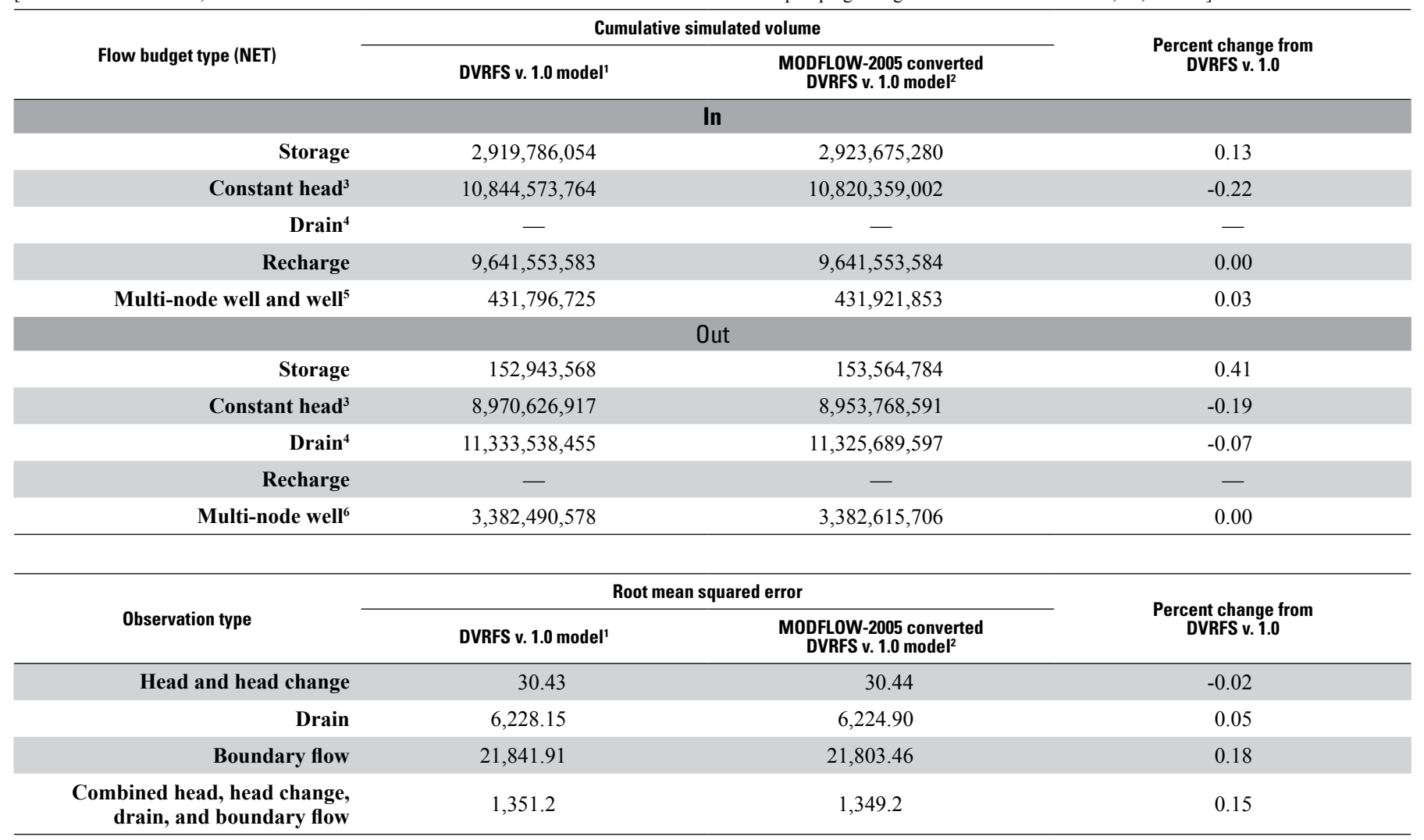

${ }^{1}$ MODFLOW-2000 (version 1.13) double precision.

${ }^{2}$ MODFLOW-2005 (version 1.6) double precision.

${ }^{3}$ Representing boundary flow.

${ }^{4}$ Representing spring flow and evapotranspiration.

${ }^{5}$ Representing irrigation return flow.

${ }^{6}$ Representing pumping.

this statistic is used in this report, as opposed to sum of squared differences (SOSD). Hill and Tiedeman (2007) and Faunt, Blainey, and others (2010) describe the concept of CSS in more detail. In addition, the most sensitive parameter from each group from the 11 parameter groups representing different types of hydraulic properties was analyzed and compared between MODFLOW-2000 DVRFS v. 1.0 and the MODFLOW-2005 version.

Simulated hydraulic head (4,899 observations), spring flows and ET (49 observations/prior-information), and boundary flows (15 prior-information) agreed well between the MODFLOW-2000 DVRFS v. 1.0 model and the MODFLOW-2005 converted model. All but 8 of the 4,899 simulated hydraulic heads using the MODFLOW-2005 conversion were within $0.1 \mathrm{~m}$ of hydraulic heads simulated using Faunt, Blainey, and others (2010), and all but 4 hydraulic heads were within $1 \mathrm{~m}$. The sum of all flow observations/prior-information differed from the sum of all simulated values by less than 1 percent, suggesting little overall bias in the conversion. The greatest change in simulated boundary flow was $162 \mathrm{~m}^{3} / \mathrm{d}$ of an estimated boundary flow of $12,476 \mathrm{~m}^{3} / \mathrm{d}$ along the Stone
Cabin Valley boundary segment (C_STNC0700) (Harrill and Bedinger, 2010, fig. A2-3). Simulated cumulative volumetric budgets also were compared between the models (table 3 ) and differed by less than 0.5 percent.

The CSS were calculated and compared between the model versions. The most significant parameter from each of the 12 parameter groups was compared. For these 12 parameters, generally very small differences exist in the CSS between the DVRFS v. 1.0 MODFLOW-2000 version and the MODFLOW-2005 conversion. The greatest deviations in CSS occurred for the storage parameters SY_PAH and STOR_12. For SY_PAH, the original CSS was 111; for the MODFLOW-2005 conversion it was 0.786. The CSS for STOR_12 was 0.0012 for the original model and 0.002 for the MODFLOW-2005 conversion. Greater differences in CSS for these two parameters are due to the different sensitivity computation methods (adjoint versus perturbation) used in MODFLOW-2000 and UCODE_2005 (Poeter and others, 2005 ) and the selection of the perturbation value specified in UCODE_2005. 


\section{Discretization Modifications}

Following conversion to MODFLOW-2005, three major modifications were made to the DVRFS model discretization: (1) top of model, (2) layer geometries, and (3) time, by adding time steps to the stress periods and lengthening the overall time period from 88 to 92 stress periods representing 1913 through 2003.

In general, the top of each numerical flow model layer is based on a smoothed version of the estimated idealized potentiometric surface and cells increase in thickness with depth (Faunt, Blainey, and others, 2010). This modification to the flow model discretization consisted of using a modification of the D'Agnese and others (1998) water-level surface described in the "Modification of the Estimated Regional Potentiometric Surface" section of this report. Initially, the revised model top surface (pl. 1) was used to adjust the existing layer tops from DVRFS v. 1.0. Where the revised model top surface was less than $10 \mathrm{~m}$ above the existing base of layer 1, the tops of deeper model layers were adjusted downward to produce a minimum saturated thickness for layer 1 of $10 \mathrm{~m}$. During model calibration for the steady-state stress period, the top of layer 1 was set to the simulated hydraulic heads of layer 1 from the previous model run.

In general, the flow model layers do not coincide with the HGUs. The geometries of the HGUs in this system are complex because of considerable folding, faulting, and other processes, and it is not possible for model layers to conform to these irregular shapes (Faunt, Blainey, and others, 2010). However, in order to reduce the hydraulic averaging and to better represent the major hydrogeologic units, the top of the flow model layers was adjusted up or down to correspond to the closest major HGU as needed to match HGU contacts. The major HGUs are defined as the combined confining units (ICU, XCU, and LCCU), the LCA, thrusted units LCCU_T1 and LCA_T1, the UCCU, the UCA, base of the volcanic-rock units, and top of the volcanic-rock units. As a result, the layer thicknesses are no longer constant through a model layer as they were in DVRFS v. 1.0 .

Time was divided into steady-state and then annual transient stress periods. The annual stress periods were subdivided into two time steps per transient stress period. In order to simulate the 1913-2003 time frame, the number of yearly transient stress periods was increased from 86 to 91 , resulting in 92 total stress periods.

\section{Model Calibration}

Model calibration is the process of changing model parameter input values, such as hydraulic conductivities, storage coefficients, and (or) drain conductances, in an attempt to match simulated conditions with observed conditions. In this report, the term "observation/prior-information" refers to values developed from field measurements, estimates, and (or) interpretations that are compared to simulated values (model outputs) to constrain the regression during calibration. MODFLOW-2005 does not contain methods internally for parameter estimation, sensitivity analysis, and uncertainty evaluation as is the case with MODFLOW-2000. These processes were done externally in PEST (Doherty, 2010). This section documents the calibration of DVRFS v. 2.0 using PEST.

\section{Hydraulic-Head Observation Weights}

In Faunt, Blainey, and others (2010), a qualifier or weight was assigned to each hydraulic-head observation that represented uncertainty based on potential errors (San Juan and others, 2010). For consistency, hydraulic-head observation weights were assigned based on the method described by San Juan and others (2010) and Faunt, Blainey, and others (2010). Uncertainty of hydraulic-head observations for the DVRFS v. 2.0 model were based on two main types of errors: hydraulic-head observation error and errors associated with the modeling process. Details and assumptions used for determining hydraulic-head observation error are found in San Juan and others (2010), and for determining modeling process error are found in Faunt, Blainey, and others (2010).

To quantify the uncertainty of the hydraulic-head observations, errors in well altitude and location, non-simulated transient stress, and water-level measurement were estimated. The contribution of these potential errors to observation uncertainty varies; generally, the errors associated with well-altitude and well-location errors are greater than those caused by non-simulated transient errors. The uncertainty of a hydraulichead observation, with respect to the well-altitude error, can be expressed as a standard deviation calculated by the following equation:

$$
\mathrm{sd}_{1}=\mathrm{AAC} / 2
$$

where

$\mathrm{sd}_{1}$ is the standard deviation, in meters, and

$\mathrm{AAC}$ is the value of the USGS Ground-Water Site Inventory (GWSI) altitude accuracy code, in meters.

The uncertainty of a hydraulic-head observation, with respect to the well-location error, can be expressed as a standard deviation calculated by the following equation: 


$$
\mathrm{sd}_{2}=(\mathrm{CAC} / 2) \times \mathrm{HG}
$$

where
$\mathrm{sd}_{2}$ is the standard deviation, in meters,
$\mathrm{CAC}$ is the value of the GWSI coordinate accuracy code, in meters, and
HG is the hydraulic gradient, unitless or meters/meter.

The uncertainty of a hydraulic-head observation also includes non-simulated transient error. Non-simulated transient errors result from uncertainty in the magnitude of waterlevel response caused by stresses not simulated in the flow model, which are typically seasonal and long-term climate changes. Non-simulated transient error can be expressed as a standard deviation calculated by the following equation:

$$
\mathrm{sd}_{3}=(\mathrm{SF}+\mathrm{LTC}) / 4
$$

where

$\mathrm{sd}_{3}$ is the standard deviation, in meters,

$\mathrm{SF}$ is the seasonal fluctuation as defined by water-

level measurements, in meters, and

LTC is the long-term climate trend, assumed to be

1 meter.

The uncertainty of a hydraulic-head observation, with respect to the measurement-accuracy error, can be expressed as a standard deviation calculated by the following equation:

$$
\mathrm{sd}_{4}=(\text { DOOBS } \times 0.001) / 2
$$

where

$\mathrm{sd}_{4}$ is the standard deviation, in meters, and

DOOBS is the depth of the observation, in meters above or below land surface.

In addition to the four sources of error associated with the hydraulic-head observations listed, two sources of error are associated with the modeling process: uncertainties in model discretization and pumpage estimates. Model-discretization errors result from inaccuracies in the geometric representation of HGUs and major structural features in the model (Hill and Tiedeman, 2003, 2007). Model-discretization error could be quantified in a number of ways; however, for the DVRFS models, the error is assumed to be normally distributed about the hydraulic-head observation with the 95-percent confidence interval being directly proportional to the distance between model cell nodes and hydraulic gradient. Hydraulic gradients were calculated from the estimated regional potentiometric surface map (pl. 1). The standard deviation for model-discretization error was computed as follows:

$$
\mathrm{sd}_{5}=\{\mathrm{NW} \times \mathrm{HG} \times[(\mathrm{TOUPOPEN} / \mathrm{MT})+2]\} / 4
$$

where

$$
\begin{gathered}
\mathrm{sd}_{5} \quad \text { is the standard deviation of model-discretization } \\
\text { error, in meters, }
\end{gathered}
$$

NW is the distance between model cell nodes, in meters, and is equal to 1,500 meters,
HG is the local hydraulic gradient, unitless or in meters/meter,

TOUPOPEN is the top of the upper open interval in the well, in meters below land surface, and

MT is the approximate thickness of the aquifer material in the model and is equal to 3,000 meters for this calculation.

Part of the calculation for standard deviation of modeldiscretization error $\left(\mathrm{sd}_{5}\right)$ includes determining the interpreted hydraulic gradient. For both DVRFS model versions, gradients were determined by using grids of various resolutions overlain on the estimated regional potentiometric maps (IT Corporation, 1996c; D'Agnese and others, 1998). The resolution of the gridded estimated potentiometric surface was not documented in Faunt, Blainey, and others (2010) and could not be easily determined. The DVRFS v. 2.0 model uses weights based on a 750-m resolution hydraulic gradient grid. Because the resolution of the grids used to calculate the gradients of the regional water-level map was different for the two models, different gradient values were determined for the same well locations. The difference in the average gradient between DVRFS v. 1.0 (Faunt, Blainey, and others, 2010) and DVRFS v. 2.0 was 0.13 and in standard deviation was 0.82 . Outliers occur with a maximum gradient difference of 6.45 and a minimum difference of -3.42 .

There are other model errors that are not due to discretization, such as incorrect geology and incorrect boundary conditions. It is not known how to estimate these errors without running alternative conceptualizations, which was beyond the scope of this work.

Using the standard deviations of a hydraulic-head observation based on the five potential errors, the standard deviation, $\mathrm{sd}_{\mathrm{h}}$, of each observation was computed by the equation

$$
\mathrm{sd}_{\mathrm{h}}=\left(\mathrm{sd}_{1}^{2}+\mathrm{sd}_{2}^{2}+\mathrm{sd}_{3}^{2}+\mathrm{sd}_{4}^{2}+\mathrm{sd}_{5}^{2}\right)^{1 / 2}
$$

where

$\mathrm{sd}_{\mathrm{h}}$ is the standard deviation of each hydraulic head or hydraulic-head-change observation, in meters,

$\mathrm{sd}_{1}$ is the standard deviation of well-altitude error, in meters,

$\mathrm{sd}_{2}$ is the standard deviation of well-location error, in meters,

$\mathrm{sd}_{3}$ is the standard deviation of non-simulated transient error, in meters,

$\mathrm{sd}_{4}$ is the standard deviation of measurementaccuracy error, in meters, and

$\mathrm{sd}_{5}$ is the standard deviation of model-discretization error, in meters.

There are many more hydraulic-head and hydraulic-headchange observations than other observation types, resulting in a clustering problem by type of observation. There is also spatial clustering due to most wells being at the NNSS or within pumping areas. Weights were adjusted to de-emphasize the 
numerous hydraulic-head and hydraulic-head-change observations to avoid these clustering issues.

Computed standard deviations of hydraulic-head observations for the DVRFS v. 2.0 model for steady-state flow conditions ranged from less than $1 \mathrm{~m}$ to about $215 \mathrm{~m}$. Because of a variety of factors, including improvements in location accuracy, measurement accuracy, and the changes in estimated hydraulic gradients, the magnitudes of the calculated standard deviations for any particular hydraulic-head observation can vary from those reported in Faunt, Blainey, and others (2010).

Differences between simulated and observed hydraulichead changes (model error) through time at a particular observation location are expected to be dominated by errors in pumpage estimates; thus, this is the only error that was considered in calculating the weighting of hydraulic-head-change observations. Pumpage-estimate error does not affect hydraulic-head observations that are assumed to represent steadystate flow conditions. Pumpage-estimate errors result from uncertainties in the pumping rate, the location of the pumped well, and the depth of pumped well openings. Pumping rates were estimated by a variety of methods and data, including irrigated acreage, flow-meter measurements, water-use reports, and power consumption (San Juan and others, 2010).

Faunt, Blainey, and others (2010) showed that the strict use of a coefficient of variation (CV) in DVRFS v. 1.0 was problematic because greater hydraulic-head-change observations were given unrealistically large standard deviations and small weights, and vice versa. To remedy this problem, a function was developed that maintained the basic premise of larger standard deviations for greater hydraulic-head changes over time but tempered the difference in the standard deviation between large and small hydraulic-head-change observations. The function used to calculate the standard deviation of a hydraulic-head-change observation is as follows:

$$
\begin{gathered}
\mathrm{sd}_{\mathrm{hc}}=4+\left[0.8 \times \ln \left(\mathrm{hc}_{\mathrm{obs}} / 40\right)\right] \text { for hc } \mathrm{obs}_{\mathrm{os}}>1.0 \\
\mathrm{sd}_{\mathrm{hc}}=1, \text { for } \mathrm{hc}_{\mathrm{obs}} \leq 1.0
\end{gathered}
$$

where

$$
\begin{aligned}
& \mathrm{sd}_{\mathrm{hc}} \text { is the standard deviation used to calculate the } \\
& \text { weight factor for the observed hydraulic-head } \\
& \text { change, in meters, } \\
& \mathrm{ln} \text { denotes the natural log of the value in } \\
& \text { parentheses, in meters, and } \\
& \mathrm{hc}_{\mathrm{obs}} \text { is the hydraulic-head-change observation, in } \\
& \text { meters. }
\end{aligned}
$$

\section{Parameter Estimation}

PEST (Doherty, 2010) was used to optimize parameter values in DVRFS v. 2.0. The parameter-estimation algorithm employed in PEST is known as the Gauss-MarquardtLevenberg method (Doherty and Hunt, 2009). This method starts with user-defined initial values for the parameters and then iteratively adjusts these values such that the sum of the squared weighted differences between the observations/ prior-information and their corresponding model-simulated values is minimized. This sum is referred to as the weighted least-squares objective (LSO) function. In this report, unweighted LSO values were used for different observation/ prior-information types to evaluate model fit, but the regression was conducted with the weighted LSO. The problem of parameter identification is also referred to as the inverse problem, which is the assignment of physical property values (for example, hydraulic conductivity, storage coefficient, etc.) for each model cell. For a large model, this can result in an extremely large number of parameters. This can be reduced by using parameterization techniques such as zonation and pilot point interpolation (Hill and Tiedeman, 2007; Doherty, 2010; Doherty and others, 2010).

\section{Regularization}

PEST provides two basic types of regularization for underdetermined inverse problems: Tikhonov regularization and a method based on Truncated Singular Value Decomposition (TSVD) known as SVD-assist (Tonkin and Doherty, 2005; Doherty, 2010; Doherty and others, 2010). For this study, Tikhonov regularization was the method of choice because correlation and instability within DVRFS v. 2.0 are the result of the presence of physical processes (Hill and Østerby, 2003), as well as a large number of hydraulic properties. Tikhonov regularization (Tikhonov and Arsenin, 1977; Doherty, 2003) is a form of Bayesian estimation in which a composite objective function is minimized (Yeh, 1986). This composite objective function consists of the weighted LSO function discussed previously and a Bayesian term that penalizes the composite objective function when parameters deviate from their mean or expected value.

For DVRFS v. 2.0, 374 parameters out of 544 estimated parameters were estimated with pilot point Tikhonov regularization with PEST, in which an expected value was assigned to each parameter (appendix 1). PEST internal utilities were used to add the regularized values, and the weights were adjusted by PEST during calibration with the regularization process as described in the "Observations/Prior-Information and Weighting" section of this report.

\section{Model Parameters}

The inverse modeling problem presented in this report is slightly highly parameterized. Because of the complex hydrogeology of the region, many parameters are required to adequately distribute the properties of the system over the model domain. The parameter values from DVRFS v. 1.0 were used as the initial values in DVRFS v. 2.0. However, because of interest in simulating in more detail the hydrologic conditions of the Amargosa Desert, several parameters were added, particularly those for the alluvial and volcanic units. 
A total of 559 parameters, inclusive of the 374 pilot points, were estimated. These parameters are lumped into 12 parameter groups in PEST, with the observation group name and number of observations in parentheses:

1. horizontal hydraulic conductivity (hk_grp, 76), in meters per day

2. vertical anisotropy (vani_grp, 17), unitless

3. pilot point hydraulic property distribution (pps_grp, $171)$, in meters per day

4. specific yield (sy_grp, 205) (includes both zones and pilot points), unitless

5. specific storage (stor_grp, 11), in meters ${ }^{-1}$

6. depth decay for hydraulic conductivity (kdep_grp, 8), in meters ${ }^{-1}$

7. fault conductance (flt_grp, 41 ), in days ${ }^{-1}$

8. drain conductance (drn_grp, 7), in square meters per day

9. recharge scaler multipliers (rch_grp, 6), unitless

10. irrigation return flow (ir_grp, 2), in cubic meters per day

11. flows for selected springs in Pahrump Valley and Amargosa Desert (drna_grp, 14) in cubic meters per day

12. precipitation multipler (ppt_grp, 1), unitless

Prior estimates of the model parameters throughout the DVRFS model domain were obtained from Faunt, Blainey, and others (2010) for use as expected values in the Tikhonov regularization process. Many of these prior parameter estimates were simply assigned the values reported in Faunt, Blainey, and others (2010). Additional parameters resulting from modifications to DVRFS v. 1.0 (such as the addition of pilot points) were assigned values based on hydrogeologic knowledge and general values from literature (Freeze and Cherry, 1979, p. 29). Any parameters that did not have a prior estimate were assigned an expected value similar to nearby parameters of the same type, which emphasized smoothness. It is recognized that this assumption of smoothness is not necessarily realistic in a hydrogeologic sense (variations in hydraulic properties can vary abruptly over short distances), but was considered for easily solving PEST algorithms. Some of the expected values did appear to violate this assumption of smoothness, or the literature values used were incorrect for this particular location. The expected values of the parameters were then changed slightly to reflect trends by the estimation process, which was guided by the observations/prior-information. This iterative process of running PEST, then changing the expected parameter values slightly, and then running PEST again, was repeated until a desired level of overall calibration was achieved and the model converged, while maintaining parameter values that were consistent with the hydrogeologic conceptualization of the flow system.
Most of the hydraulic characteristics are parameterized based on the zonation patterns used in DVRFS v. 1.0 as described by Faunt, Blainey, and others (2010, figs. F-12-34), with some modifications. As for DVRFS v. 1.0, HGUs are the basis for assigning horizontal hydraulic conductivity, depth decay of hydraulic conductivity, vertical anisotropy, and storage characteristics to the cells of the DVRFS v. 2.0 model grid using the HUF package (Anderman and Hill, 2000, 2003). Model input arrays also were used to account for variations in the hydraulic properties within HGUs by zone. The same vertical anisotropy (the ratio of horizontal to vertical hydraulic conductivity) parameters in DVRFS v. 1.0 are used for each HGU parameter. A regularization group was defined in PEST for each parameter group. The final calibrated parameter values are listed in appendix 1. Although final parameter sensitivities are listed, parameter sensitivity is based on the current values of the parameters and can change when the parameter values change. This is particularly true given the nonlinearity of the model.

To add more detail in the Amargosa Desert, several of the previous zonal properties were split into multiple parameters (appendix 1). The emphasis of this update was to improve simulation of groundwater flow in the Amargosa Desert. As described in the "Representation of Lithologic and Textural Variations in the Amargosa Desert" section of this report, all HGUs above the lower VSU in the Amargosa Desert were subdivided into 31 zones based on lithology (table 2). These 31 lithology types were lumped into 7 texture classes (fig. 11) for the regional model. Essentially used as zones within the model, these classes were used to estimate hydraulic conductivity, vertical anisotropy, and storage coefficient parameter types. This resulted in 21 new parameters ( 3 parameter types for each of the 7 classes).

In addition to these zonal based properties, the alluvial hydraulic properties within Pahrump Valley were not welldifferentiated in DVRFS v. 1.0. As there are little data readily available to do this differentiation, pilot point interpolation was used (Doherty and others, 2010). The pilot points were used for interpolation of hydraulic conductivity for each of the alluvial units above bedrock (alluvial aquifers and confining units (combined) and upper and lower VSU) throughout Pahrump Valley (fig. 12; table 4). The 57 pilot points were distributed horizontally. Appendix 1 lists and figure 12 shows the location of the estimated hydraulic conductivities for the three sets of hydraulic-conductivity values. Table 4 describes the statistical distribution of hydraulic properties of the Pahrump Valley basin-fill deposits.

In the HUF package, model layers can be defined as either confined or convertible between confined and unconfined (Anderman and Hill, 2003). Similar to DVRFS v. 1.0, specific storage is defined for each HGU. If a cell contains more than one HGU, the specific-storage value for a cell equals a thickness-weighted average of the specific-storage values of the HGUs. Other than the Amargosa Desert, the same specific storage parameters in DVRFS v. 1.0 were used. 


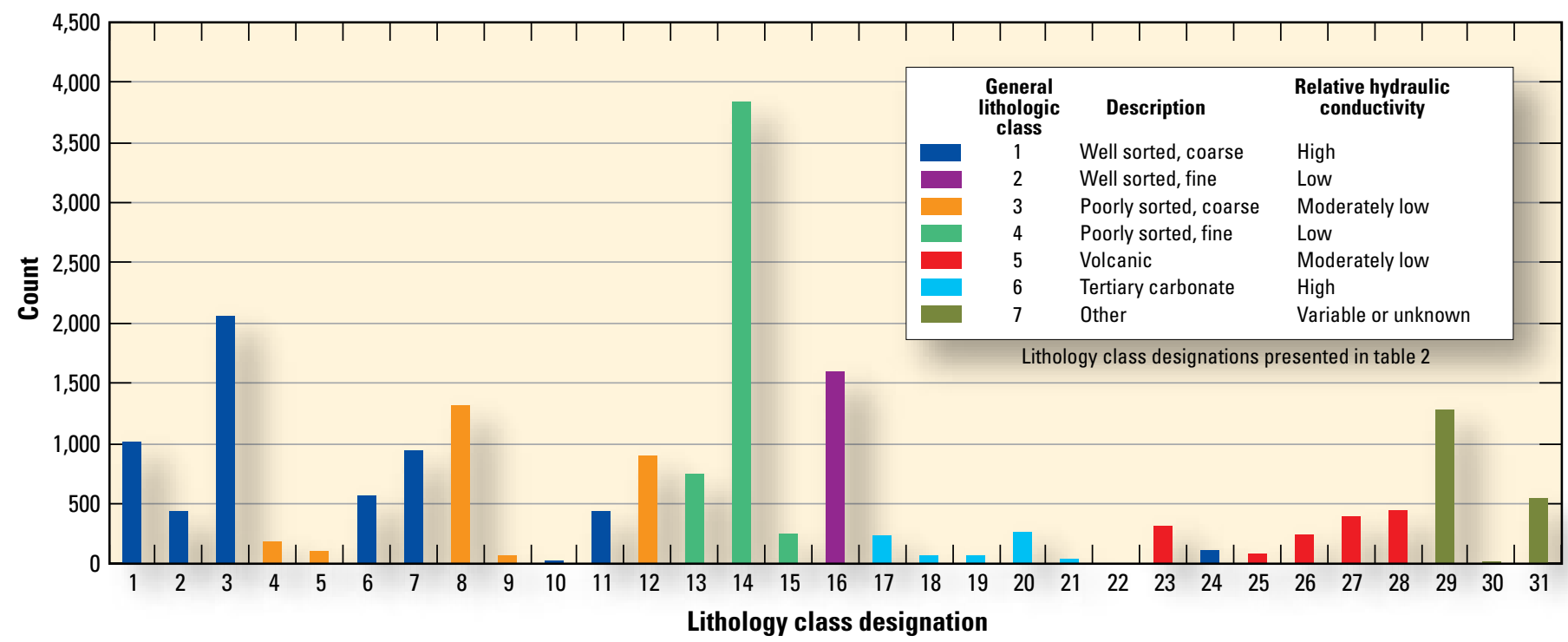

Figure 11. Classification of the Amargosa Desert 31 lithologies into 7 lithology-based texture parameters. X-axis is lithology class number (table 2), Y-axis shows number of lithologies per class by cells.

Table 4. Statistical distribution of hydraulic-conductivity values of the Pahrump Valley basin-fill deposits.

\begin{tabular}{|c|c|c|c|}
\hline \multirow{2}{*}{ Hydrogeologic unit } & \multicolumn{3}{|c|}{ Hydraulic conductivity (meters/day) } \\
\hline & Minimum & Average & Maximum \\
\hline Alluvium $^{1}$ & 0.0008 & 39 & 860 \\
\hline Upper volcanic- and sedimentary-rock unit & 0.003 & 4 & 101 \\
\hline Lower volcanic- and sedimentary-rock unit & 0.001 & 2 & 100 \\
\hline
\end{tabular}

Similar to DVRFS v. 1.0, all layers in DVRFS v. 2.0 were simulated as confined, and the storage consequences of watertable changes over time in layer 1 were simulated by using a storage coefficient in the top model layer that was equivalent to a specific yield. The top of layer 1 was defined as the water-level free surface (see "Modification of the Estimated Regional Potentiometric Surface" section of this report). There were little data readily available to determine the distribution of specific yield throughout the study area. Therefore, specific yield was parameterized by using pilot-point interpolation by inverse distance weighting (fig. 13). Inverse distance weighted interpolation assumes that the interpolation should be influenced most by nearby points and less by more distant points. The interpolated surface is a weighted average of the scatter points with the weight assigned to each data point decreasing as the distance from the interpolated point to the data point increases (Davis, 1986). The pilot points are used to set specific yield based on the major permeability zones in DVRFS v. 1.0 (Faunt, Blainey, and others, 2010, fig. F-36), allowing specific yield in DVRFS v. 2.0 to vary within the original hydraulic-conductivity zones specified in DVRFS v. 1.0. In the alluvial basins where the specific yield is most variable and has prior information based on aquifer tests, it was interpolated by using inverse distance weighting based on a scattering of pilot points (fig. 13; corresponding to recharge zones 1,5, and 9 as a surrogate for varying properties within the basin fill; Faunt, Blainey, and others, 2010, fig. F-36, table F-16). Different groupings of specific yield pilot points (groups am, pv, and pp) were developed for the Amargosa Desert, Pahrump Valley, and other valleys.

Zones of relatively low specific yield in the foothills or lower-altitude mountain ranges (corresponding to recharge zone 3; Faunt, Blainey, and others, 2010, fig. F-36, table F-16) were also added and represented as a separate parameter zone (fig. 13). Relatively high specific yield is estimated in the major mountain ranges (fig. 13; corresponding to recharge zones 2, 4, 6, 7, and 8; Faunt, Blainey, and others, 2010, fig. F-36, table F-16). These greater specific-yield values in the higher-altitude mountain ranges serve to help buffer the spatial variability of recharge rates.

As in DVRFS v. 1.0, the vertical exponential decay $(\lambda)$ of hydraulic conductivity was implemented in the HUF package, allowing specified HGUs to be relatively impermeable at depth and relatively permeable near the land surface. This vertical exponential decay is believed to be the result of increasing effective stress with depth compacting sediments and closing fractures. For example, a value of $\lambda=1 \times 10^{-5}$ produces a hydraulic conductivity of 93 percent of the original value at a depth of $3,000 \mathrm{~m}$; a value of $\lambda=1 \times 10^{-4}$ produces a hydraulic conductivity of 50 percent of the original value, and a value of $\lambda=1 \times 10^{-3}$ produces a hydraulic conductivity of 0.1 percent of the original value. A graphical representation of this feature is shown in Faunt, Blainey, and others (2010, fig. F-35, table F-12). Although the vertical exponential decay 


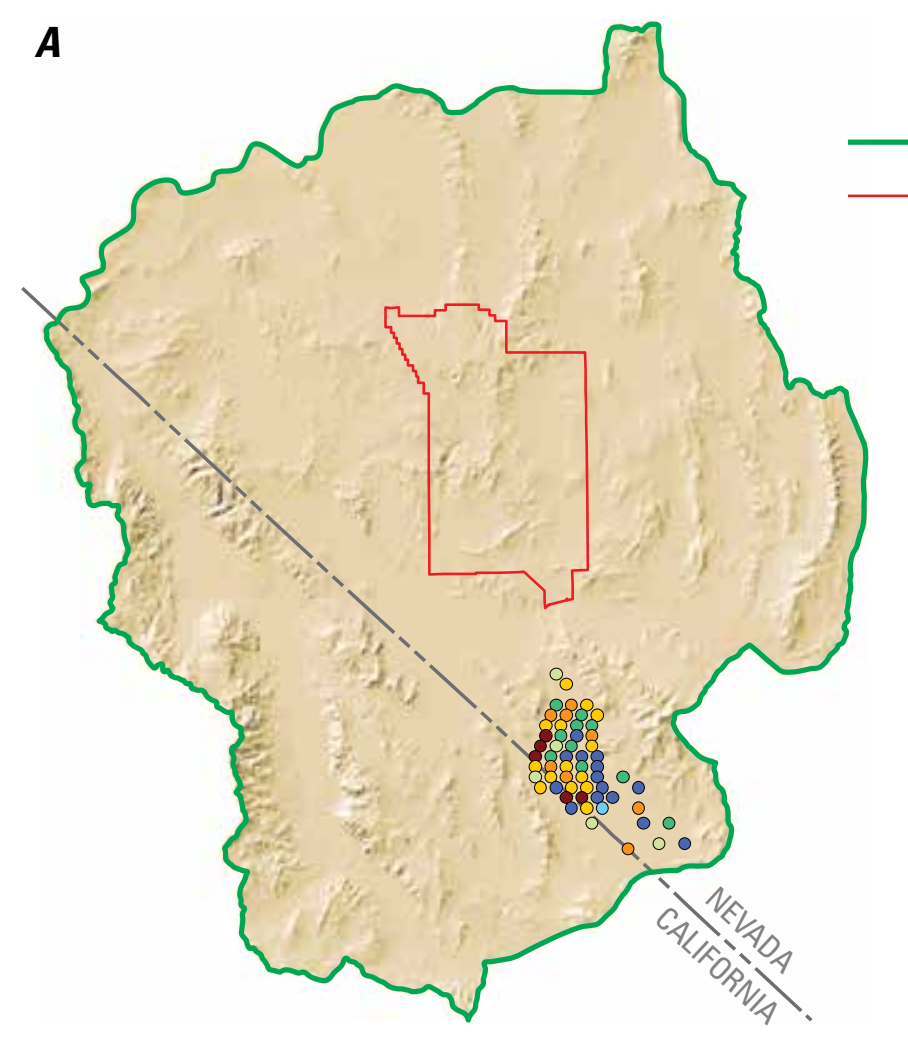

\section{EXPLANATION}

Death Valley regional groundwater flow system model boundary

Nevada National Security Site boundary

Simulated hydraulic conductivity, in

meters per day

0.000861 to 0.005000

- 0.005001 to 0.010000

- 0.010001 to 0.050000

- 0.050001 to 0.500000

- 0.500001 to 1.000000

- 1.000001 to 5.000000

- 5.000001 to 10.000000

○ 10.000001 to 50.000000

- 50.000001 to 100.000000

- 100.000001 to 526.550520
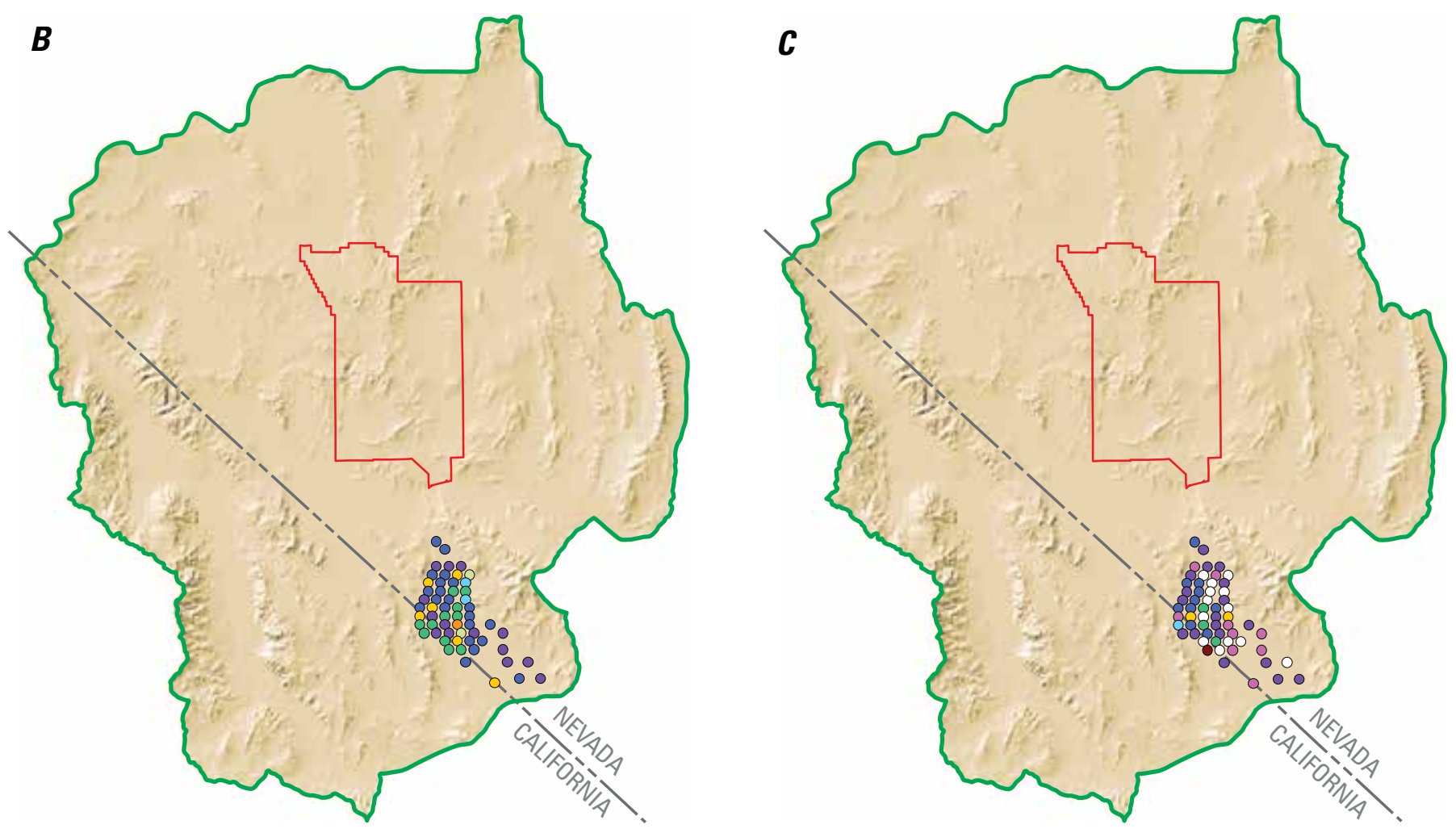

Figure 12. Distribution of pilot points and hydraulic conductivity in Pahrump Valley. $A$, Alluvial (basin-fill) units, $B$, Upper volcanic- and sedimentary-rock unit, and $C$, Lower volcanic- and sedimentary-rock unit. Active model extent shown for reference. 


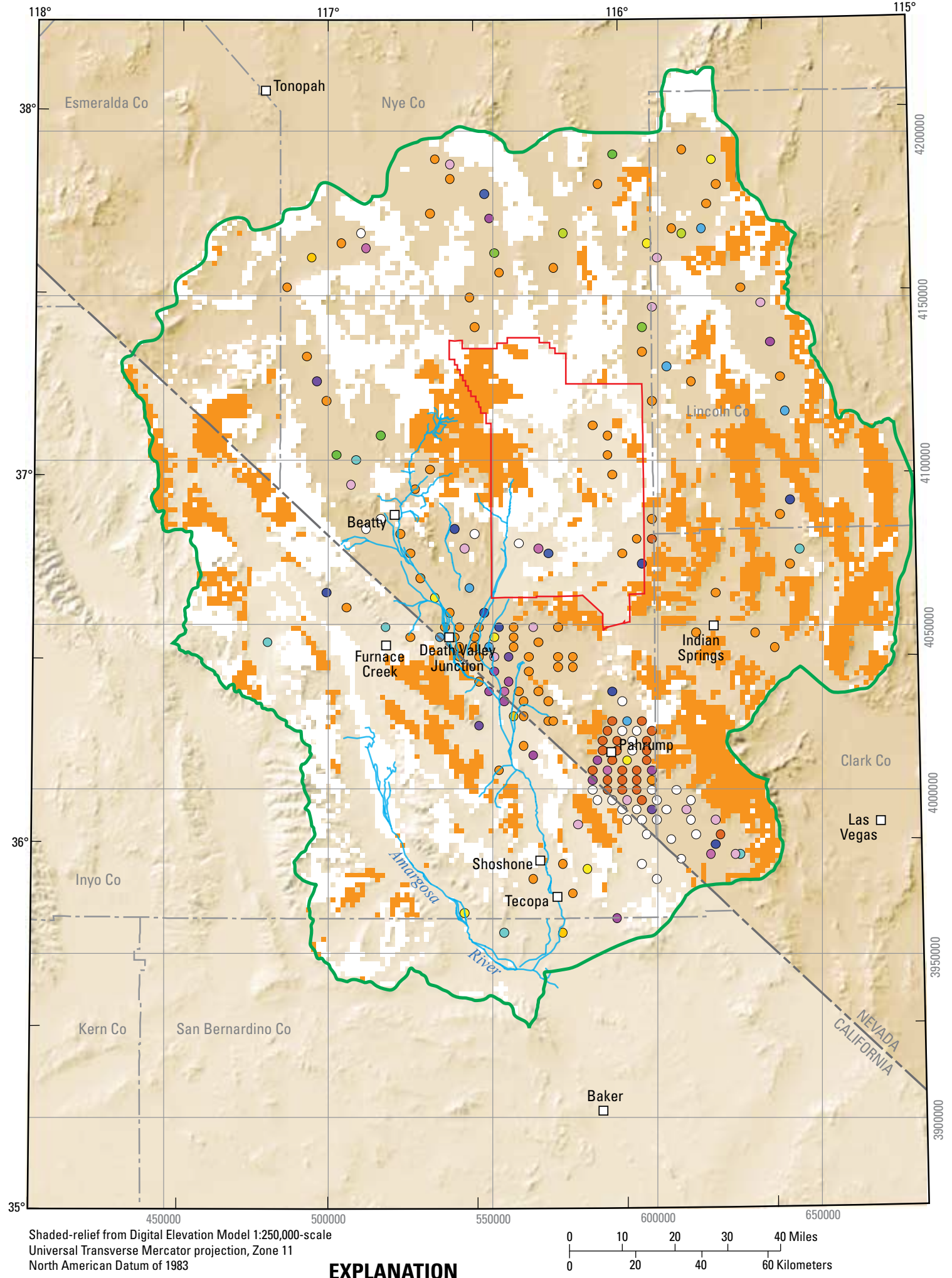

\section{Simulated specific yield, unitless}

Relatively low specific yield (0.007) in the foothills or

higher-altitude mountain ranges

Relatively moderate specific yield (0.33) in lower-altitude

mountain ranges and the floor of Death Valley

Death Valley regional groundwater flow system model boundary Nevada National Security Site boundary

\section{EXPLANATION}

Simulated specific yield, unitless - Point locations are used to interpolate specific yield throughout valley fill and remaining regions

0.001000 to $0.020000 \bigcirc 0.100001$ to $0.120000 \bigcirc 0.200001$ to $0.220000 \bigcirc 0.300001$ to 0.320000

0.020001 to $0.040000 \bigcirc 0.120001$ to $0.140000 \bigcirc 0.220001$ to 0.240000

0.040001 to 0.060000 O 0.140001 to 0.160000 ○ 0.240001 to 0.260000

0.060001 to $0.080000 \bigcirc 0.160001$ to $0.180000 \bigcirc 0.260001$ to 0.280000

0.080001 to $0.100000 \bigcirc 0.180001$ to $0.200000 \bigcirc 0.280001$ to 0.300000

Figure 13. Distribution of zones and pilot points for simulated specific yield in the Death Valley regional groundwater flow system v. 2.0 model. 
of hydraulic conductivity was included in the numerical flow model, regularization was used to decrease the weighting of this parameter, thus decreasing its effect. In several areas, particularly in Pahrump Valley, additional depth decay parameters were added to limit the area where the vertical exponential decay had a strong influence. This was done because the model itself cannot successfully estimate $\lambda$ by a regional-scale calibration. While there appears to be a correlation between horizontal hydraulic conductivity and depth decay, most of the data are shallow.

The model input required for the HFB package is the hydraulic characteristic of the barrier, that is, the hydraulic conductivity of the barrier divided by the width of the barrier. It was assumed that the width is $1 \mathrm{~m}$ so that the input value of the horizontal-flow barrier is equal to the barrier's conductance term. The hydraulic conductivity is determined by using estimated parameters in the fault conductance group. In order to test the sensitivity and effect of all the flow-barrier features, all of the HFBs were included in the parameter estimation in this calibration (fig. 5). In addition, three new features (Rock Valley, Cane Springs, and the Boundary fault, represented by the hydraulic characteristic parameters B_ROCK_VAL, B_ CANE_SPR, and B_BOUNDARY, respectively) were added to the HFB package (fig. 5). Enhanced permeability zones for these faulted areas were represented by parameter zones composed of model cells on both sides of the HFB. For example, a transmissive pathway between Mercury, Nevada, and Ash Meadows (termed the "megascale channel") first identified by Winograd and Pearson (1976), was represented in the LCA by parameters K243_LCA and K244_LCA. Additional higher permeability zones were added along these three HFBs in the LCA (parameters K2_RV_LCA [combined Rock Valley and Cane Springs faults] and $\mathrm{K}_{2}$ YF_LCA [Boundary fault]).

Groundwater discharge by ET and spring flow is simulated by using the DRN package (Faunt, Blainey, and others, 2010, fig. F-7, table F-4). The simulated discharge is calculated as the drain conductance multiplied by the difference in altitude between the simulated hydraulic head and the drain elevation. The drain conductances are defined by using the hydraulic properties of materials through which groundwater flows to the surface. Although the values were re-estimated during calibration, these parameters represent the same materials as in Faunt, Blainey, and others (2010).

Two main types of groundwater recharge occur in the DVRFS: (1) natural infiltration from precipitation, and (2) irrigation return flow. The natural recharge rates were calculated by using a net-infiltration model (Hevesi and others, 2003; San Juan and others, 2010), modified for potential climate variability over time, and is described in the "Recharge from Precipitation" section of this report. In DVRFS v. 1.0, recharge parameters are among the most sensitive parameters. Therefore, recharge zone multiplication arrays, based on the hydraulic properties of the upper part of the DVRFS, were used to spatially adjust the estimates of the net infiltration model (Hevesi and others, 2003). Although these recharge zone multiplier array values were re-estimated, these parameters represent the same zonations as in DVRFS v. 1.0. The values for the multipliers are presented in appendix 1 as the rch_grp parameters.

Return flow of pumpage through subsequent infiltration of excess irrigation, lawn water, or septic tank wastewater was simulated as it was with DVRFS v. 1.0. The magnitude and timing of these returns have not been precisely quantified, but estimates of irrigation returns were estimated by Stonestrom and others (2003) for irrigated fields in the southern Amargosa Desert using chloride mass balance. Stonestrom and others (2003) estimated these return flows to be between 8 and 16 percent of irrigation over 10 to 70 years. Harrill (1986, p. 19) estimated return flows for Pahrump Valley as 70 percent of domestic pumpage, 50 percent of public supply and commercial pumpage, and 25 percent of irrigation pumpage and noted that the return flows depend on the timing and method by which the water is returned to the flow system. For DVRFS v. 1.0, the return flow was specified as 20 percent of the estimated annual pumpage, lagged by 7 years (Faunt, Blainey, and others, 2010). The total return flow was simulated by using the WEL package. A return-flow recharge well was simulated in each cell with irrigation pumpage applied to the uppermost model layer.

\section{Observations/Prior-Information and Weighting}

The 10,403 observations/prior-information are based on those from Faunt, Blainey, and others (2010, fig. F-10) and new data between 1999 and 2003 (table 5). In order to improve model calibration, some new observations/priorinformation and observation/prior-information types were added. Four main types of observations/prior-information were used in calibrating DVRFS v. 2.0:

1. water levels (steady-state hydraulic head, hydraulic-head change, vertical hydraulic-head gradients), in meters or unitless

2. groundwater discharge, in cubic meters per day

3. basin flows (interior and boundary), in cubic meters per day

4. transmissivity, in square meters per day

These observation types were split into seven observation/ prior-information groups in PEST with the number of observations in parentheses:

1. steady-state water levels, in meters $(1,171)$

2. drawdown, in meters $(6,734)$

3. vertical hydraulic-head gradients, unitless (122)

4. drain flow (spring flow and ET), in cubic meters per day and drain altitude penalty, in meters (49)

5. constant-head boundary flow (controls flow across model boundaries), in meters (15)

6. interbasin flow (internal to model), in cubic meters per day (41)

7. transmissivity, in square meters per day (283) 
Table 5. Summary of observations/prior-information used in the Death Valley regional groundwater flow system v. 2.0 model.

$[\leq$, less than or equal to; $>$, greater than]

\begin{tabular}{|lc}
\hline \multicolumn{1}{c}{ Type of observation } & Number of observations \\
\hline Head & 1,171 \\
\hline Head change & 6,734 \\
\hline • Observed value $\leq 1.0$ meter & 1,744 \\
\hline • Observed value $>1.0$ meter & 274 \\
\hline Vertical head gradients & 122 \\
\hline Discharge from evapotranspiration or springs & 49 \\
\hline Constant-head boundary flow & 15 \\
\hline Interbasin flow & 41 \\
\hline Transmissivity & 253 \\
\hline
\end{tabular}

\section{Hydraulic Head, Hydraulic-Head Change, and Vertical Hydraulic-Head Gradient}

Water-level and drawdown observations were similar in magnitude to those from Faunt, Blainey, and others (2010), and the updates and extensions to these data are discussed in the "Hydrologic Data Updates" section of this report. Steadystate water levels are observations obtained at times that are assumed to be representative of pre-development conditions or are more recent observations in areas not influenced by pumping. Most of the hydraulic-head-change observations are representative of pumping responses in wells, whereas some represent rising water levels. Steady-state and transient observation wells are shown on figure 7. Hydraulic-head observations in the Spring Mountains were given an extremely low weight because they may be perched and therefore, may not be part of the regional flow system. Hydraulic-headchange observations are based on the transient water levels and are calculated as the water level rises or declines from the first water-level observation. In order to ensure that the vertical hydraulic-head gradients are preserved, where known, observed values were calculated and added as difference observations. This resulted in 122 observations from 29 well pairs (fig. 14). Approximately half of the wells are from multiple completions in the same borehole with the other half being wells that are near to each other, but completed in different HGUs.

\section{Groundwater Discharge}

Discharge from springs and ET areas were simulated with the DRN package. The 49 drain flow observations/priorinformation reported in Faunt, Blainey, and others (2010) were used during calibration. In DVRFS v. 1.0, these observations/ prior-information became insensitive when simulated hydraulic heads dropped below the drain altitude. In order to provide a head-sensitive component to the LSO function, a headdependent penalty was added because the residual became a constant value when the head was below land surface. In DVRFS v. 2.0, this is achieved by introducing a penalty into the LSO function (fig. 15). This penalty is implemented in PEST as a series of below-drain-altitude control values (or flow-control values). Each drain observation/prior-information group, where hydraulic heads are constrained by the drain altitude during calibration, contains one of these drain penalty values. A post-processor was used to evaluate the calculated steady-state hydraulic-head distribution accounting for the distance between the simulated hydraulic head and the landsurface altitude. If the simulated hydraulic head was above land surface within a particular cell, the "residual" assigned to the flow-control value was set to the simulated drain flow residual. If the simulated hydraulic head was $0.5 \mathrm{~m}$ below the land surface, a non-zero "residual" was assigned to the flowcontrol value. This non-zero "residual" increases with depth as a square-root function of the difference between the altitude of the simulated hydraulic head and $0.5 \mathrm{~m}$ below land surface. When the simulated hydraulic head was exactly at land surface, the "residual" was set to the drain flow residual.

\section{Boundary Flow and Interbasin Flow}

Two types of interbasin flow values are used in DVRFS v. 2.0: (1) boundary flows, which are flows across the model boundary, and (2) flow between basins (interbasin flow) internal to the model domain. Water-budget and Darcy calculation estimates of flow from basins adjacent to the DVRFS were used as observations/prior-information for flow into and out of the DVRFS model domain (Harrill and Bedinger, 2010; San Juan and others, 2010; Faunt, Blainey, and others, 2010). Boundary flows were estimated, in part, from a regional potentiometric-surface map developed by Bedinger and Harrill (2010) to delineate areas outside of the model domain that contributed inflow or received outflow across the model boundary.

The type and location of the boundaries as well as the estimated flow are summarized by Faunt, Blainey, and others (2010, table F-2). The subsegment number and name are used as the observation/prior-information name (Faunt, Blainey, and others, 2010, table F-2). The same observations/priorinformation from DVRFS v. 1.0 were used for DVRFS v. 2.0 and are tabulated in Harrill and Bedinger (2010). Observations/prior-information are flows through boundary subsegments and are simulated as constant-head boundaries.

Subsequent use of DVRFS v. 1.0 showed that flows between some hydrographic areas within the DVRFS domain did not agree well with literature estimates (Nevada Department of Water Resources, 1972; Harrill and others, 1988; Pohlmann and Ye, 2012). This was especially noticeable in the estimated flow into the Yucca Flat hydrographic area (HA 159) from the Emigrant Valley-Groom Lake Valley hydrographic area (HA 158A) (fig. 16). DVRFS v. 1.0 simulated between 40,000 and $50,000 \mathrm{~m}^{3} / \mathrm{d}$ (between 12,000 and 15,000 ac-ft/yr) flowing into Yucca Flat from the north. Published estimates of the interbasin flow into Yucca Flat from the Emigrant ValleyGroom Lake Valley area are estimated to be no greater than $3,600 \mathrm{~m}^{3} / \mathrm{d}(1,000 \mathrm{acre}-\mathrm{ft} / \mathrm{yr})$ (Winograd and Thordarson, 1975; Harrill and others, 1988). To help constrain interbasin 


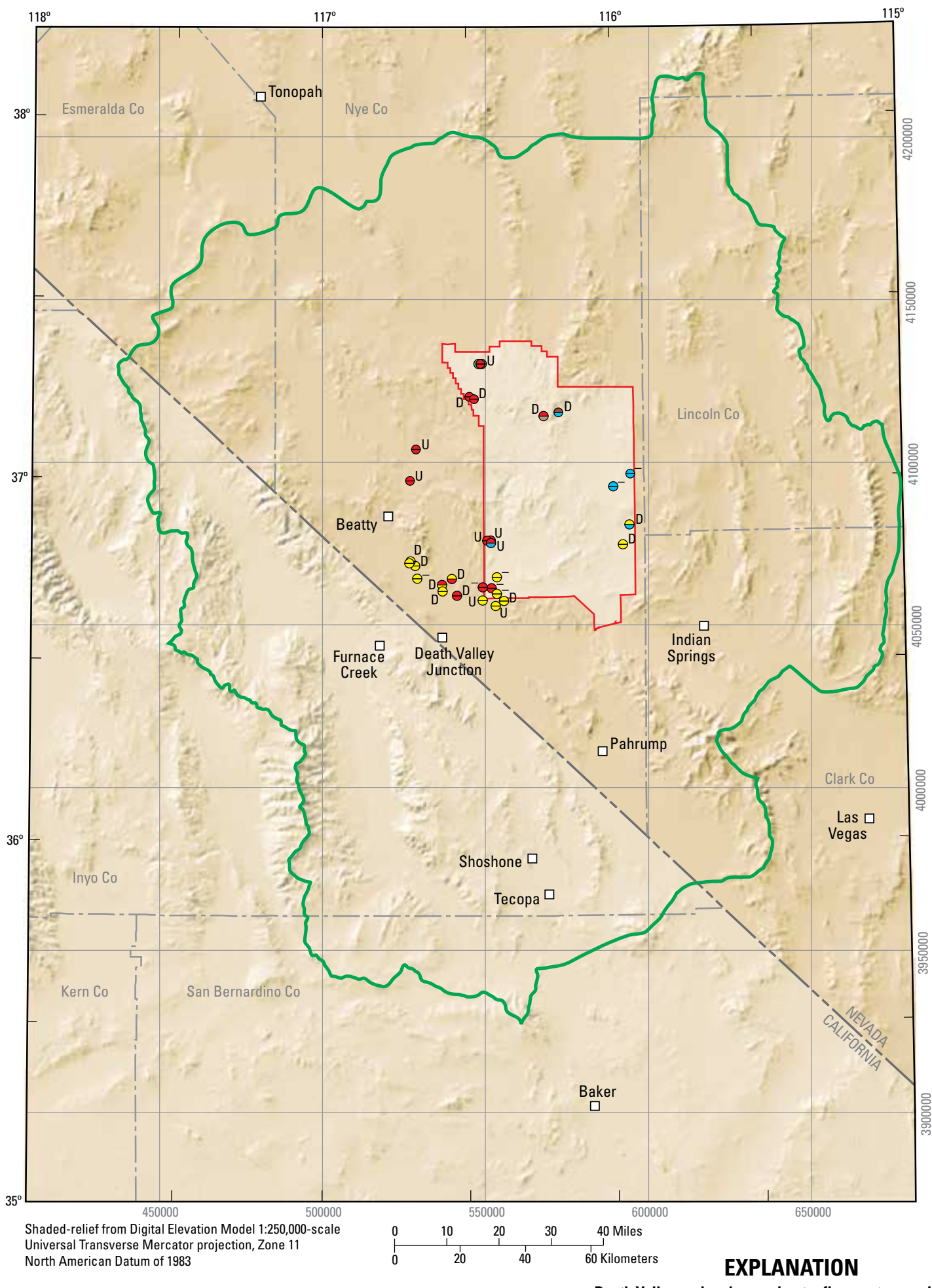

$\begin{array}{llllll}\text { Universal Transverse Merc ator projection, Zone } 11 & 0 & 20 & 40 & 60 \text { Kilometers } & \text { EXPLANATION }\end{array}$

Death Valley regional groundwater flow system model boundary Nevada National Security Site boundary

$\ominus^{U}$ Well pair observation locations - Upper part of symbol is generalized hydrogeologic unit (HGU) for shallow well, lower part of symbol is generalized HGU for deep well, O yellow for basin-fill HGU, ored for volcanic-rock HGUs, O brown for clastic-rock confining units, $\bigcirc$ blue for carbonate-rock aquifers. $\mathrm{U}=$ upward gradient, $\mathrm{D}=$ downward gradient, $(-)=$ no gradient

Figure 14. Location of well pairs where vertical hydraulic-head gradients are available for use in the Death Valley regional groundwater flow system v. 2.0 model. 


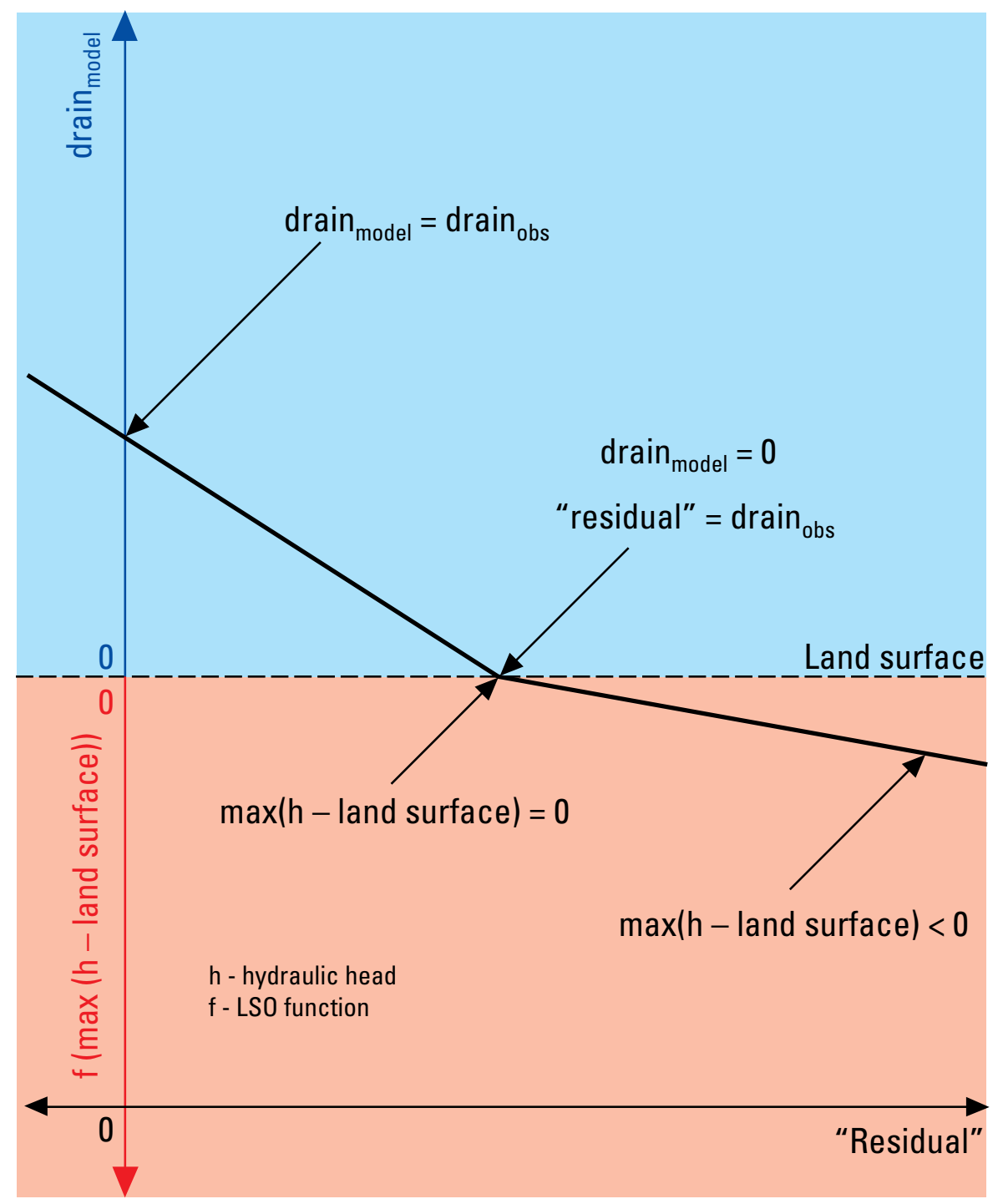

Figure 15. Schematic drawing of implementation of drain penalty into the least-squares objective (LSO) function.

flow within the model domain, flow estimates were compiled from NDWR (1972) and Harrill and others (1988) and used as observations/prior-information. The compilation of these interbasin flows as observations/prior-information to be used in the model is presented in table 6 . It was assumed that where no data were presented in NDWR (1972) and Harrill and others (1988) that the interbasin flow was between zero and $1,690 \mathrm{~m}^{3} / \mathrm{d}(500 \mathrm{ac}-\mathrm{ft} / \mathrm{yr})$. Selected interbasin flow estimates of zero were also added as observations/prior-information to help constrain flow in important areas such as Yucca Flat. These interbasin flow estimates have a high degree of uncertainty and are often based on the differences between recharge and discharge in water-balance estimates. Therefore, observation/ prior-information weights for the interbasin flow observations/ prior-information initially were set to relatively low values. This approach is consistent with that used in the DVRFS v. 1.0 model.

\section{Transmissivity}

Additional observation/prior-information points for the model calibration in the form of transmissivity estimates from aquifer tests are included in DVRFS v. 2.0. There are 126 observation/prior-information locations for transmissivity (fig. 17) from multiple sources, including Belcher and others (2001); the USGS Nevada Water Science Center aquifer test website, at http://nevada.usgs.gov/water/AquiferTests/index. htm; Nye County Early Warning Drilling Program at http:// www.nyecounty.com/ewdpmain.htm; and specific-capacity test data from well logs from the NDWR at http://water.nv.gov/ data/welllog/wlog.zip, giving a total of 283 transmissivity observations/prior-information used in the DVRFS v. 2.0 model (appendix 2). Wells are located throughout the study area in a variety of HGUs, including basin-fill deposits, volcanic rocks, and carbonate rocks. Multiple aquifer tests have been done in a number of wells that represent tests in different screened intervals at the same location. 


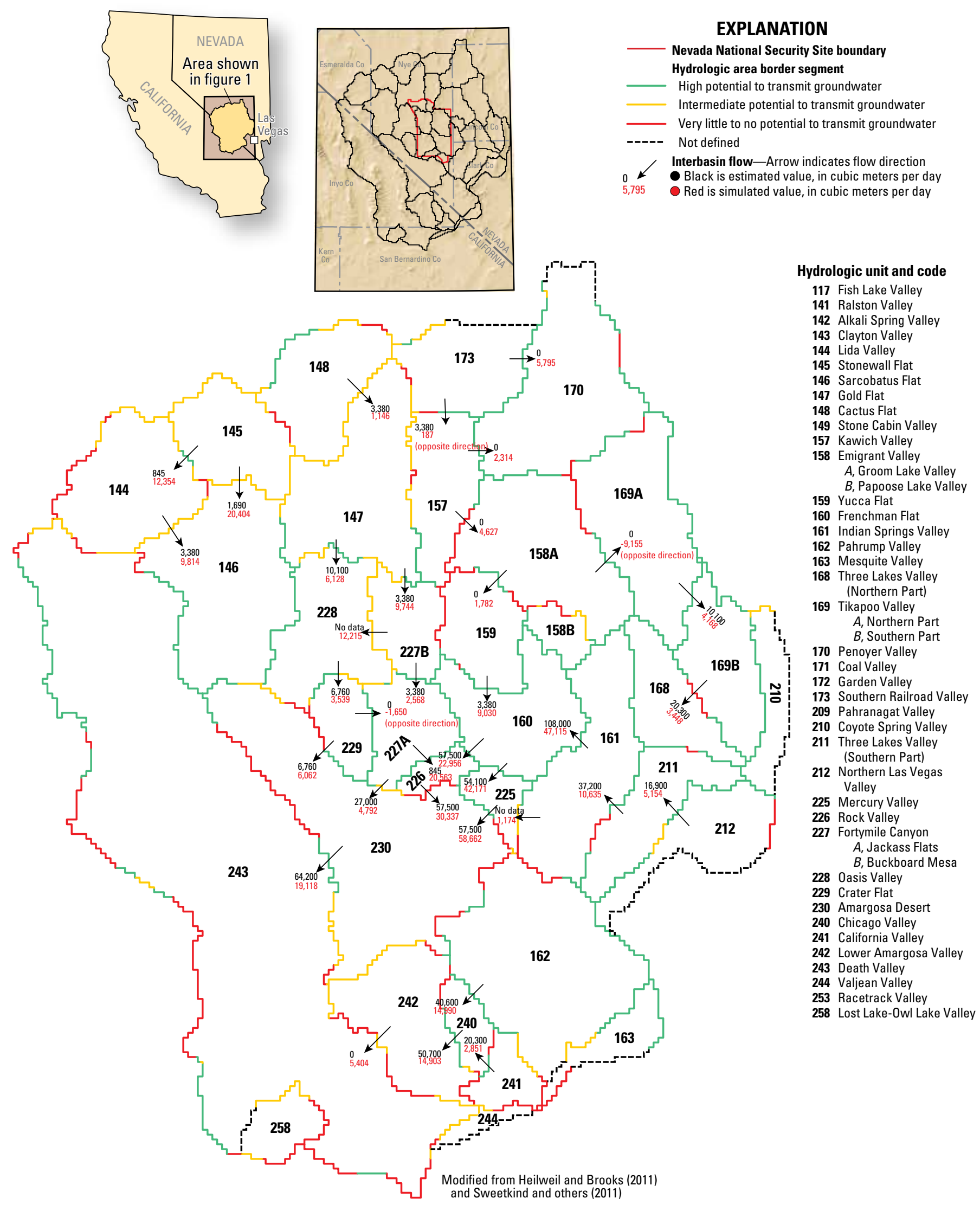

Figure 16. Interbasin flow observations/prior-information and simulated values in the Death Valley regional groundwater flow system v. 2.0 model, and potential to transmit groundwater. 
Table 6. Interbasin flow observations/prior-information used in the Death Valley regional groundwater flow system v. 2.0 model and simulated results.

[Location of basins depicted on figure $16 . \mathrm{m}^{3} / \mathrm{d}$, cubic meters per day; multiply value in $\mathrm{m}^{3} / \mathrm{d}$ by 0.3 to obtain values in acre-feet per year; NDWR, Nevada Division of Water Resources; - - , no data]

\begin{tabular}{|c|c|c|c|c|}
\hline $\begin{array}{c}\text { Observation/ } \\
\text { Prior-information }\end{array}$ & $\begin{array}{l}\text { Calculated value } \\
\left(\mathrm{m}^{3} / \mathrm{d}\right)\end{array}$ & $\begin{array}{c}\text { Simulated value } \\
\left(\mathrm{m}^{3} / \mathrm{d}\right)\end{array}$ & Residual $^{4}$ & Reference for observed value \\
\hline HA_144_146 & 3,380 & 9,814 & 6,434 & NDWR, 1972 \\
\hline HA_145_144 & 845 & 12,354 & 11,509 & NDWR, 1972 \\
\hline HA_145_146 & 1,690 & 20,404 & 18,714 & NDWR, 1972 \\
\hline HA_147_227B & 3,380 & 9,744 & 6,364 & NDWR, 1972 \\
\hline HA_147_228 & 10,100 & 6,128 & $-3,972$ & NDWR, 1972 \\
\hline HA_148_147 & 3,380 & 1,146 & $-2,234$ & NDWR, 1972 \\
\hline HA_157_158A & 0 & 4,627 & 4,627 & NDWR, 1972 \\
\hline HA_157_170 & 0 & 2,314 & 2,314 & NDWR, 1972 \\
\hline HA_158A_159 & 0 & 1,782 & 1,782 & NDWR, 1972 \\
\hline HA_158A_169A & 0 & $(9,155)$ & $-9,155$ & NDWR, 1972 \\
\hline HA_159_160 & 3,380 & 9,030 & 5,650 & NDWR, 1972 \\
\hline HA_160_225 & 54,100 & 42,171 & $-11,929$ & NDWR, 1972 \\
\hline HA_160_226 & 57,500 & 22,956 & $-34,544$ & NDWR, 1972 \\
\hline HA_161_160 & 108,000 & 47,115 & $-60,885$ & NDWR, 1972 \\
\hline HA_161_225 & - & 1,174 & - & NDWR, 1972 \\
\hline HA_162_240 & 40,600 & 14,990 & $-25,610$ & NDWR, 1972 \\
\hline HA_169A_169B & 10,100 & 4,168 & $-5,932$ & NDWR, 1972 \\
\hline HA_169B_168 & 20,300 & 3,448 & $-16,852$ & NDWR, 1972 \\
\hline HA_173_157 & 3,380 & (187) & $-3,567$ & NDWR, 1972 \\
\hline HA_173_170 & 0 & 5,795 & 5,795 & NDWR, 1972 \\
\hline HA_211_161 & 37,200 & 10,635 & $-26,565$ & NDWR, 1972 \\
\hline HA_212_211 & 16,900 & 5,154 & $-11,746$ & NDWR, 1972 \\
\hline HA_225_230 & 57,500 & 58,662 & 1,162 & NDWR, 1972 \\
\hline HA_226_230 & 57,500 & 30,337 & $-27,163$ & NDWR, 1972 \\
\hline HA_227A_226 & 845 & 20,563 & 19,718 & NDWR, 1972 \\
\hline HA_227A_230 & 27,000 & 4,792 & $-22,208$ & NDWR, 1972 \\
\hline HA_227B_227A & 3,380 & 2,568 & -812 & NDWR, 1972 \\
\hline HA_227B_228 & - & 12,215 & - & NDWR, 1972 \\
\hline HA_228_229 & 6,760 & 3,539 & $-3,221$ & NDWR, 1972 \\
\hline HA_229_227A & 0 & $(1,650)$ & $-1,650$ & NDWR, 1972 \\
\hline HA_229_230 & 6,760 & 6,062 & -698 & NDWR, 1972 \\
\hline HA_230_243 & 64,200 & 19,118 & $-45,082$ & NDWR, 1972 \\
\hline HA_240_242 & 50,700 & 14,903 & $-35,797$ & Harrill and others, 1988 \\
\hline HA_241_240 & 20,300 & 2,851 & $-17,449$ & Harrill and others, 1988 \\
\hline HA_242_243 & 0 & 5,404 & 5,404 & Harrill and others, 1988 \\
\hline Total & 669,180 & 404,970 & $-277,599$ & \\
\hline
\end{tabular}

${ }^{1}$ Observation/prior-information name is based on hydrographic area number (Harrill and others, 1988) and indicates flow from one hydrographic area to another; for example, observation/prior-information HA_144_146 is an estimate of flow from basin 144 to 146.

${ }^{2}$ Only selected "zero" observations/prior-information from NDWR (1972) and Harrill and others (1988) are included as model observations/prior-information.

${ }^{3}$ Simulated values in parentheses indicate flow in the wrong direction or flow in the opposite direction if estimated flow is 0 .

${ }^{4}$ Positive values indicate simulated interbasin flow is greater than the observation, while negative values indicate simulated basin flow is less than the observation. 


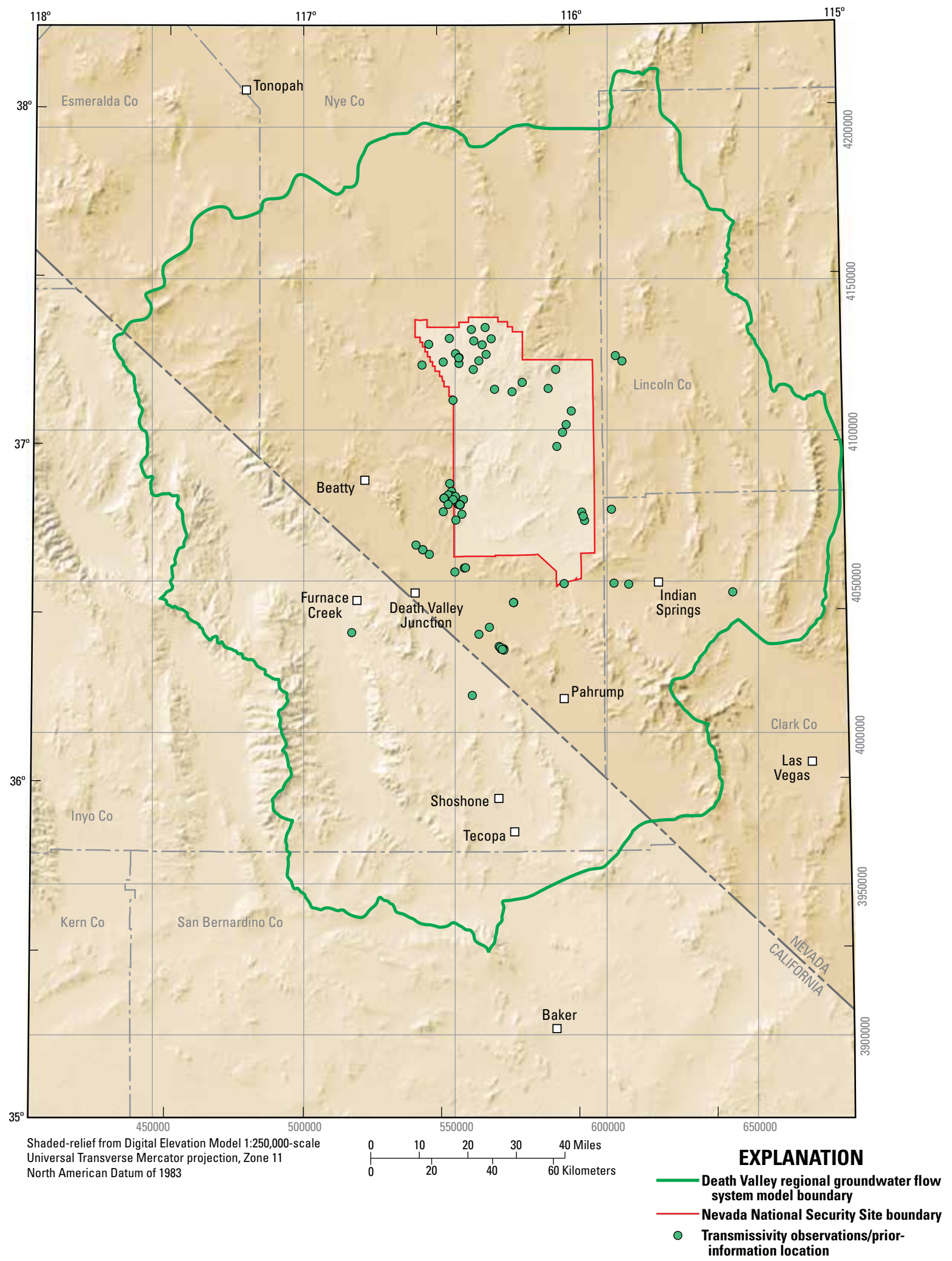

A data point may depict multiple transmissivity observations/prior-information that occur at the same location but at different altitudes.

Figure 17. Location of transmissivity observations/prior-information used in the Death Valley regional groundwater flow system v. 2.0 model. 
Transmissivity observations/prior-information in basinfill deposits were also acquired from the NDWR database of available well installations (http://water.nv.gov/data/ welllog/wlog.zip, accessed September 26, 2012), including specific-capacity estimates. Data were evaluated on a caseby-case basis and were used only if the pumping produced enough stress on the aquifer to indicate a robust estimate of transmissivity.

Transmissivity was estimated from specific capacity (Thomasson and others, 1960) as follows:

$$
\mathrm{T}=1,460 \mathrm{SC}
$$

where

$\mathrm{T}$ is transmissivity, in gallons per day per foot, and

$\mathrm{SC}$ is specific capacity, in gallons per minute per foot.

Note that this empirical relation is for unconfined aquifers. Most of the specific-capacity data used is from wells completed in the basin-fill deposits.

The transmissivity observations/prior-information used in the calibration process were assigned weights that, as a group, were similar to the other observation/prior-information weights. There is uncertainty in the transmissivity estimates used as observations/prior-information because of their application in a regional model with cells $1,500 \mathrm{~m}$ on a side and a model that simulates porous-media flow in the fractured media, as well as uncertainty associated with the actual aquifer-test interval. Furthermore, the aquifer tests may not have detected hydrologic differences that might exist in between units that were not influenced by these particular aquifer tests. The relation between specific capacity and transmissivity is empirical and is also subject to uncertainty.

Because MODFLOW-2005 uses hydraulic conductivity and does not calculate transmissivity, it was necessary to develop a method to compute model-simulated transmissivity to compare to the measured values. Transmissivity as priorinformation, was used to adjust hydraulic conductivity and are related as follows:

$$
\mathrm{T}=\mathrm{Kb}
$$

where

$\mathrm{T}$ is transmissivity, in square meters per day,

$\mathrm{K}$ is hydraulic conductivity, in meters per day, and

$\mathrm{b}$ is thickness, in meters.

Thickness (b) here refers to the length of the tested interval in the aquifer test, usually the open interval of the well. Hydraulic-conductivity values were assigned or estimated for the HGU(s) in the flow model for the specific model cell that corresponded to the real-world location of the aquifer test.

\section{Modification of Observation/Prior-Information Weights}

During calibration, observation/prior-information weights were initially assigned by using the error-based weighting approach described in the "Hydraulic-Head Observation Weights" section of this report. Weights applied to the observations can be found in the model file archive. From this foundation, the following changes were made:

1. Weights on several hydraulic-head observations were decreased because of high sensitivity values, indicating a great influence on the calibration. The decreased weights of these specific observations limited their impact on the calibration.

2. As in the calibration of DVRFS v. 1.0, groundwater discharge observation/prior-information coefficients of variation (CVs) (but not the observations/priorinformation themselves) were decreased during the calibration process because the determination of $\mathrm{CVs}$ may not have considered adequately all sources of observation/prior-information error, indicating greater uncertainty. Model error, discharge-estimation methods, and magnitude of discharge rate were considered during the calibration process and, where necessary, $\mathrm{CVs}$ were modified to reflect (a) the cumulative error, (b) the relative observation/prior-information importance, and (c) the confidence in the observation.

3. The seven observation/prior-information groups were scaled to account for so many hydraulic-head and hydraulic-head-change observations/prior-information relative to the other observation/prior-information types. This was accomplished by considering the value of the objective function for each group; group sensitivity was not considered.

The contribution to the objective function of the sum of squared weighted residuals (SOSWR) at the end of calibration of DVRFS v. 2.0 is presented in table 7. The following generalizations can be made about the information presented in table 7:

1. Hydraulic heads maintained the predominant role in the objective function.

2. Hydraulic-head changes (Drawdown-group dd) were secondarily predominant and the groups for vertical hydraulic head and discharge contributed a similar amount.

3. Interbasin flow observations/prior-information were less certain and scaled to be an order of magnitude smaller part of the objective function.

4. Transmissivity observations/prior-information were thought to be uncertain on a regional modeling scale due to lumping of heterogeneities in the model and the large cell size compared to the volume of material affected during an aquifer test. They were weighted so that the SOSWR for the group was similar to that of the other groups. 
Table 7. Contribution of observations/prior-information to the objective function of the sum of squared weighted residuals at the end of calibration of Death Valley regional groundwater flow system v. 2.0.

[SOSWR, sum of squared weighted residuals; sqrt, square root]

\begin{tabular}{|c|c|c|c|c|c|c|}
\hline Group name & SOSWR & $\begin{array}{c}\text { Number of members in } \\
\text { group (\#) }\end{array}$ & $\begin{array}{l}\text { Average contribution to } \\
\text { the objective function of } \\
\text { each observation/prior- } \\
\text { information in the group } \\
\text { (SOSWR/\#) }\end{array}$ & $\begin{array}{c}\text { Standard error by group } \\
\text { (sqrt[SOSWR/\#]) }\end{array}$ & $\begin{array}{l}\text { Average percent } \\
\text { contribution to total } \\
\text { SOSWR of single obser- } \\
\text { vation/prior-information } \\
\text { in the group }\end{array}$ & $\begin{array}{l}\text { Total percent group } \\
\text { contributes to the } \\
\text { objective function }\end{array}$ \\
\hline Heads & 340,852 & 1,171 & 291 & 17 & 0.04 & 51.21 \\
\hline Drawdown & 96,384 & 6,734 & 14 & 4 & 0.00 & 14.48 \\
\hline Vertical heads & 65,806 & 122 & 539 & 23 & 0.08 & 9.89 \\
\hline Drains & 29,388 & 49 & 600 & 24 & 0.09 & 4.42 \\
\hline Boundary flow & 7,470 & 15 & 498 & 22 & 0.07 & 1.12 \\
\hline Interbasin flow & 11,073 & 41 & 270 & 16 & 0.04 & 1.66 \\
\hline Transmissivity & 114,623 & 253 & 253 & 21 & 0.07 & 17.22 \\
\hline Summary & 665,596 & 8,385 & 79 & 9 & 0.01 & 100.0 \\
\hline
\end{tabular}

\section{Evaluation of Estimated Parameters}

The calibrated model was evaluated to assess the accuracy of simulated results. An advantage of using nonlinear regression to calibrate the model is that a substantial methodology exists for model evaluation that facilitates a better understanding of model strengths and weaknesses. In order to evaluate the model, the following outputs were analyzed: (1) the model fit (consisting of hydraulic heads and flows, including discharge, boundary flows, and interbasin flows), (2) the regional water budget, and (3) the values of parameter estimates and their associated sensitivities. Selected areas within the model domain were also evaluated.

Evaluation of the model and the associated statistics for stress periods through 1998 (for appropriate comparison) indicates that DVRFS v. 2.0 simulates conditions similar to DVRFS v. 1.0. Table 8 and figures 18 and 19 show that the model matches the observed values reasonably well and overall better than the previous simulation. In addition, an evaluation of the DVRFS v. 2.0 simulated water budget shows that the model matches both observed flow data and the previous model results (table 8). Figure 18 presents the observed versus simulated values and residuals for steady-state hydraulic head (fig. 18A), hydraulic-head change (fig. 18B), vertical hydraulic-head difference (fig. 18C), spring/ET discharge (fig. 18D), boundary flux (fig. 18E), and interbasin flow (fig. 18F). For the most part, the simulated values of these observations/ prior-information match the measured/estimated values fairly well, falling along the 1:1 line. Residuals appear to be random, falling around the " 0 " line.

\section{Water Levels}

As was done previously in DVRFS v. 1.0, the model fit to the steady-state hydraulic heads was evaluated by using absolute values for residuals with less than $10 \mathrm{~m}$ considered good, between $10 \mathrm{~m}$ and $20 \mathrm{~m}$ considered moderate, and greater than $20 \mathrm{~m}$ considered poor. The fit of simulated to observed hydraulic heads is generally good in most areas of nearly flat hydraulic gradients and moderate in the remainder of the nearly flat hydraulic gradient areas (fig. 19).

The steady-state heads are most poorly matched in the Pahrump Valley area. There are good matches (residuals of plus or minus $10 \mathrm{~m}$ ) between simulated and observed steadystate heads in the northwestern part of Pahrump Valley and along the Nevada-California state line. Most of the rest of the steady-state heads are within plus or minus $50 \mathrm{~m}$ of the observed values.

The fit of simulated to observed hydraulic heads is also poor in areas of steep hydraulic gradients. Similar to the results of DVRFS v. 1.0, most of these larger residuals can be attributed to (1) insufficient representation of the hydrogeology in the HFM, (2) misinterpretation of the hydraulic heads, (3) model error associated with grid cell size, or (4) a combination of the first three factors. The greatest hydraulichead residuals are associated with the high-altitude hydraulic heads in the Spring Mountains. Similar to the results of DVRFS v. 1.0, patterns in the spatial distribution of residuals show a nonrandom distribution, indicating some model error (fig. 19). The RMSE of the combined hydraulic-head and hydraulic-head-change observations/prior-information is reduced by more than 42 percent from DVRFS v. 1.0 to DVRFS v. 2.0 (table 8). Mean error of the steady-state hydraulic heads was $-0.84 \mathrm{~m}$.

The hydraulic-head changes show some areas of relatively poor fit (fig. 18B), particularly in the vicinity of Beatty, Nevada in the northern part of the Amargosa Desert and in some parts of Pahute Mesa at the NNSS (see fig. 1 for locations). The mean error for hydraulic-head change (drawdown) was $-0.81 \mathrm{~m}$. Some observed water-level increases are not reproduced in the model; approximately 20 percent of the observed water levels increased, but are not accurately simulated in the model. There are two areas on figure $18 B$ where the hydraulic-head differences show roughly horizontal and vertical patterns. The roughly horizontal pattern occurs on the upper part of the graph to the left of the 1:1 line. Simulated 
Table 8. Comparison of simulated cumulative volumetric flow budgets and root mean squared error through the 1998 stress period between the Death Valley regional groundwater flow system (DVRFS) v. 1.0 and DVRFS v. 2.0 models.

[The DVRFS v. 2.0 model includes pumping changes, framework revisions, and variable recharge; volume in cubic meters $\left(\mathrm{m}^{3}\right)$ ]

\begin{tabular}{|c|c|c|c|}
\hline \multirow{2}{*}{ Flow budget component (Net) } & \multicolumn{2}{|c|}{ Cumulative simulated volume } & \multirow{2}{*}{$\begin{array}{l}\text { Percent change from } \\
\text { DVRFS v. } 1.0^{3}\end{array}$} \\
\hline & DVRFS v. $1.0^{1}$ & DVRFS v. $2.0^{2}$ & \\
\hline Storage & $2,766,842,486$ & $1,928,825$ & -30 \\
\hline Constant head ${ }^{4}$ & $1,873,946,847$ & ${ }^{5} 631,327,812$ & -66 \\
\hline Drain $^{6}$ & $-11,333,538,455$ & ${ }^{7}-10,242,363,568$ & -10 \\
\hline Recharge & $9,641,553,583$ & $9,822,731,379$ & 2 \\
\hline Multi-node well and well ${ }^{8}$ & $-2,950,693,853$ & $2,144,968,098$ & -27 \\
\hline \multirow{2}{*}{ Observation type } & \multicolumn{2}{|c|}{ Root mean squared error ${ }^{9}$} & \multirow{2}{*}{$\begin{array}{l}\text { Percent change from } \\
\text { DVRFS v. } 1.0^{3}\end{array}$} \\
\hline & DVRFS v. $1.0^{1}$ & DVRFS v. $2.0^{2}$ & \\
\hline Head and head change & 30.43 & 17.57 & -42 \\
\hline Constant head ${ }^{4}$ & $21,841.91$ & 2,890 & -87 \\
\hline Drain $^{5}$ & $6,228.15$ & 2,359 & -62 \\
\hline $\begin{array}{r}\text { Combined head, head change, } \\
\text { drain, and boundary flow }\end{array}$ & $1,351.21$ & 224 & -83 \\
\hline
\end{tabular}

${ }^{1}$ MODFLOW-2000 (version 1.13) double precision.

${ }^{2}$ MODFLOW-2005 (version 1.6) double precision.

${ }^{3}$ Includes pumping changes and hydrogeologic framework model revisions; less than 0.3 percent of changes are from the hydrogeologic framework model revisions.

${ }^{4}$ Representing boundary flows.

${ }^{5}$ Target boundary flow cumulative through 1998 is 709,860,818 $\mathrm{m}^{3}$.

${ }^{6}$ Representing spring flow and evapotranspiration.

${ }^{7}$ Observed spring flow cumulative through 1998 is $-11,685,296,054 \mathrm{~m}^{3}$.

${ }^{8}$ DVRFS v. 2.0 flow model has irrigation return flow in WEL package that has been summed with pumpage from Multi-Node Well package for comparison.

${ }^{9}$ Root mean squared error (RMSE) is calculated for head and boundary flow at steady-state, head change for the entire simulation period, and drain for the 1998 stress period.

hydraulic-head difference is between zero and $-60 \mathrm{~m}$, and the observed hydraulic-head differences are between -10 and $-50 \mathrm{~m}$. The vertical pattern occurs in the lower part of the graph to the right of the 1:1 line. Simulated hydraulic-head differences are between zero and $10 \mathrm{~m}$. These residuals are in areas near Beatty, Nevada, and on Pahute Mesa at the NNSS. These conditions are probably caused by simulated hydraulic diffusivities being too high, and (or) pumping not being great enough for the horizontal pattern, and hydraulic-conductivity and storage values being too low, and (or) pumping being too great for the vertical pattern. Hydraulic diffusivity controls the spatial distribution of head changes over time; the greater the diffusivity, the more spatially spread out the head changes are and consequently, the smaller the head changes are for a given location (and vice versa).

Figure 20 shows that some of the hydraulic heads in the steady-state stress period are above land surface, particularly in areas of rapidly shifting topographic relief. Some of the hydraulic heads above land surface in the valley bottoms are the result of the hydraulic heads in the drains representing ET areas and springs that are moving water from the LCA to the surface. These hydraulic heads tend to be above land surface because they are under confined conditions. The hydraulic head in the deep drains (such as in Ash Meadows and Death Valley) is a reflection of how much energy is needed to produce the observed discharge from the system; the model is matching discharge at these locations, not hydraulic heads. This discharge is controlled by the drain conductance. In many cases, the model-estimated drain-conductance value is a compromise between the hydraulic head in the drain to produce the appropriate discharge and the hydraulic heads in the surrounding areas where observations/prior-information exist. In other areas, such as in the Lower Amargosa Valley (fig. 16) in the vicinity of Shoshone and Tecopa, Calif., surface-water features (such as Grimshaw Lake and the perennially flowing reaches of the Amargosa River) appear to be accurately simulated. Flowing wells are present in some of the low-permeability playa deposits, such as Alkali Flat north of Eagle Mountain (fig. 1). Simulated hydraulic heads above land surface in these areas reasonably represent field conditions.

Hydraulic-head-change observations/prior-information are greatest for wells in Pahrump Valley, Amargosa Desert, and Penoyer Valley, where the observed hydraulic heads began declining in the 1960s and 1970s (Faunt, D'Agnese, and O'Brien, 2010), and these declines were generally matched by simulated hydraulic heads (fig. 21). The simulated hydraulic heads over time were compared with observed hydraulic heads by using hydrographs from 869 of the wells in the model domain. Representative hydrographs for observation wells in different pumping areas are presented in figure 21. In general, trends in observed hydraulic-head declines in the monitoring wells are simulated; however, spikes in hydraulic head are not. 
$\boldsymbol{A}$

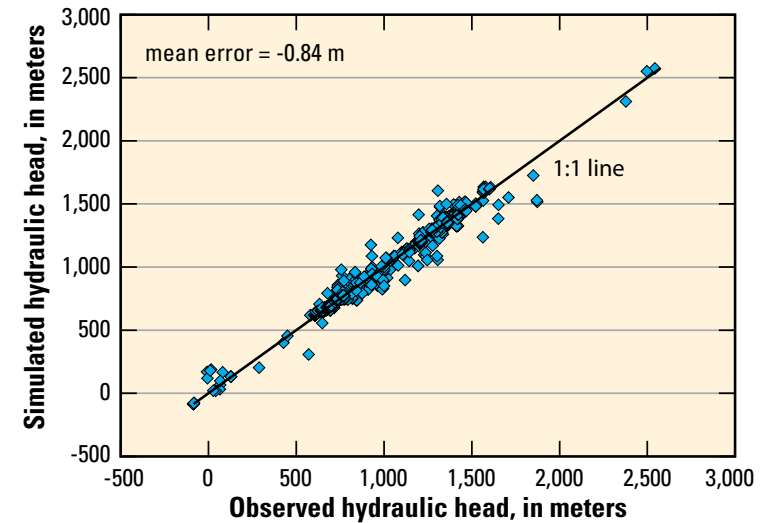

B

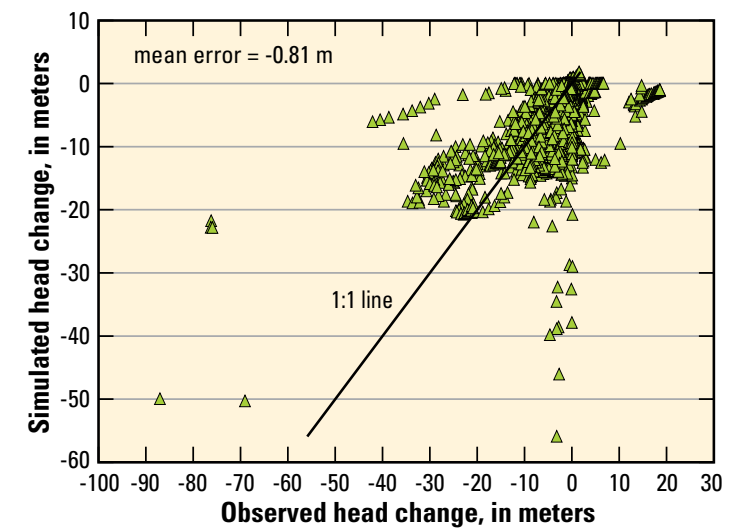

C

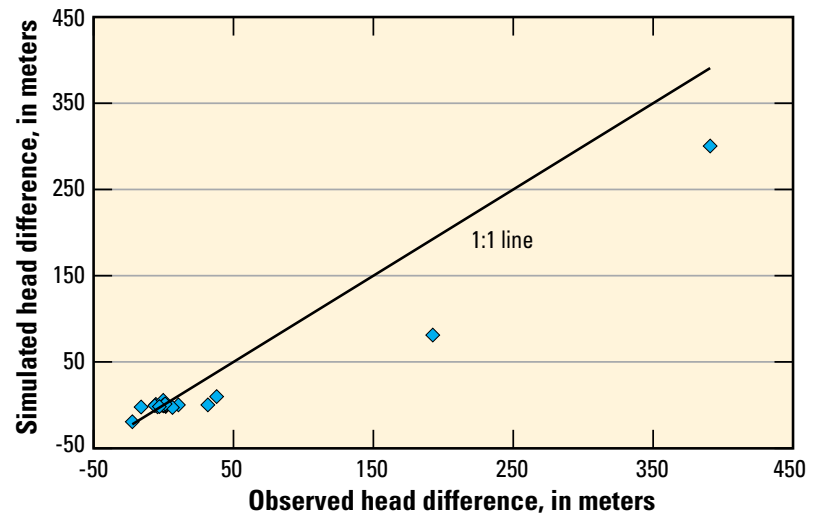

D

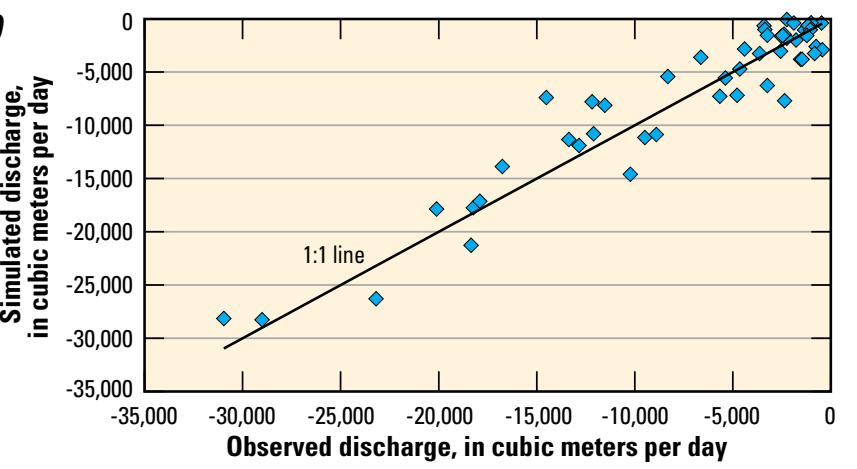

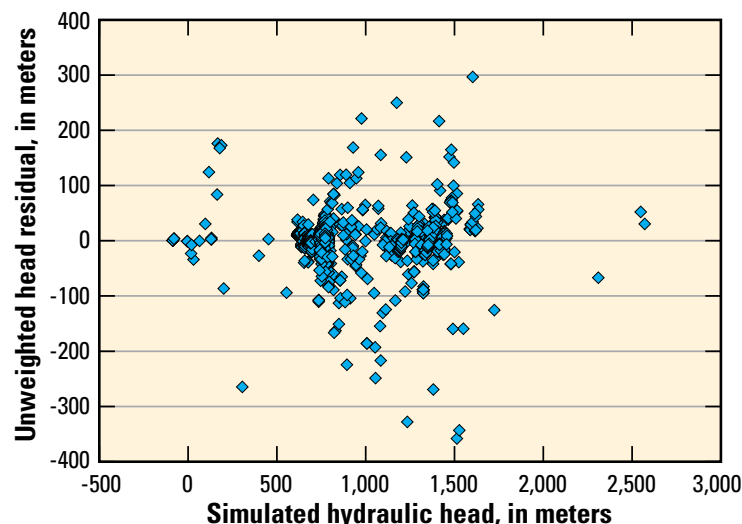
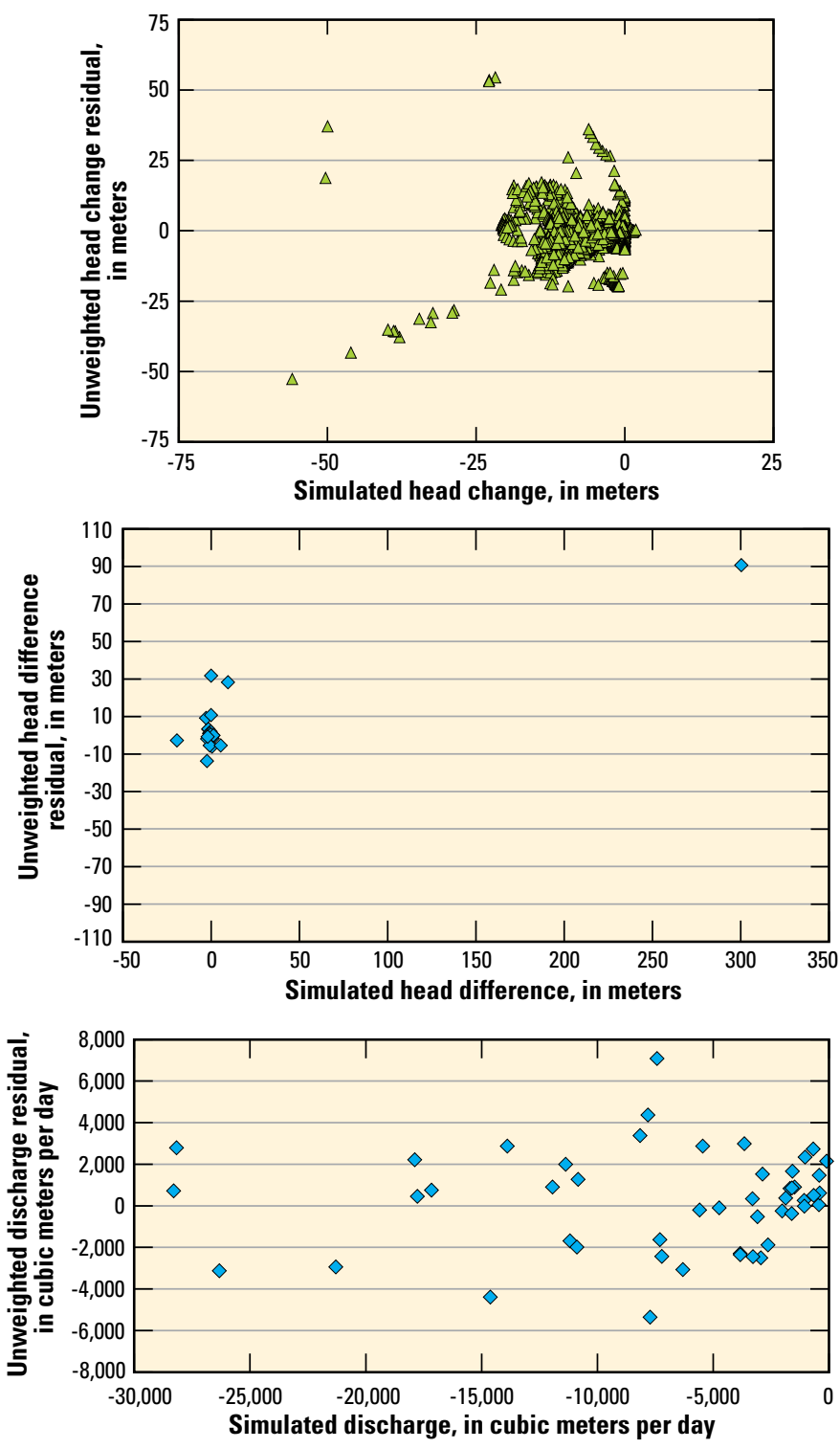

Figure 18. Observed/prior-information ( $x$-axis) versus simulated (y-axis) values for $A$, steady-state hydraulic head, $B$, transient hydraulic-head change, $C$, vertical hydraulic-head difference, $D$, steady-state discharge, $E$, steady-state boundary flow, and $F$, steadystate interbasin flow. To the right of each figure is the simulated ( $x$-axis) versus unweighted residual ( $y$-axis) for the observation/priorinformation types. 

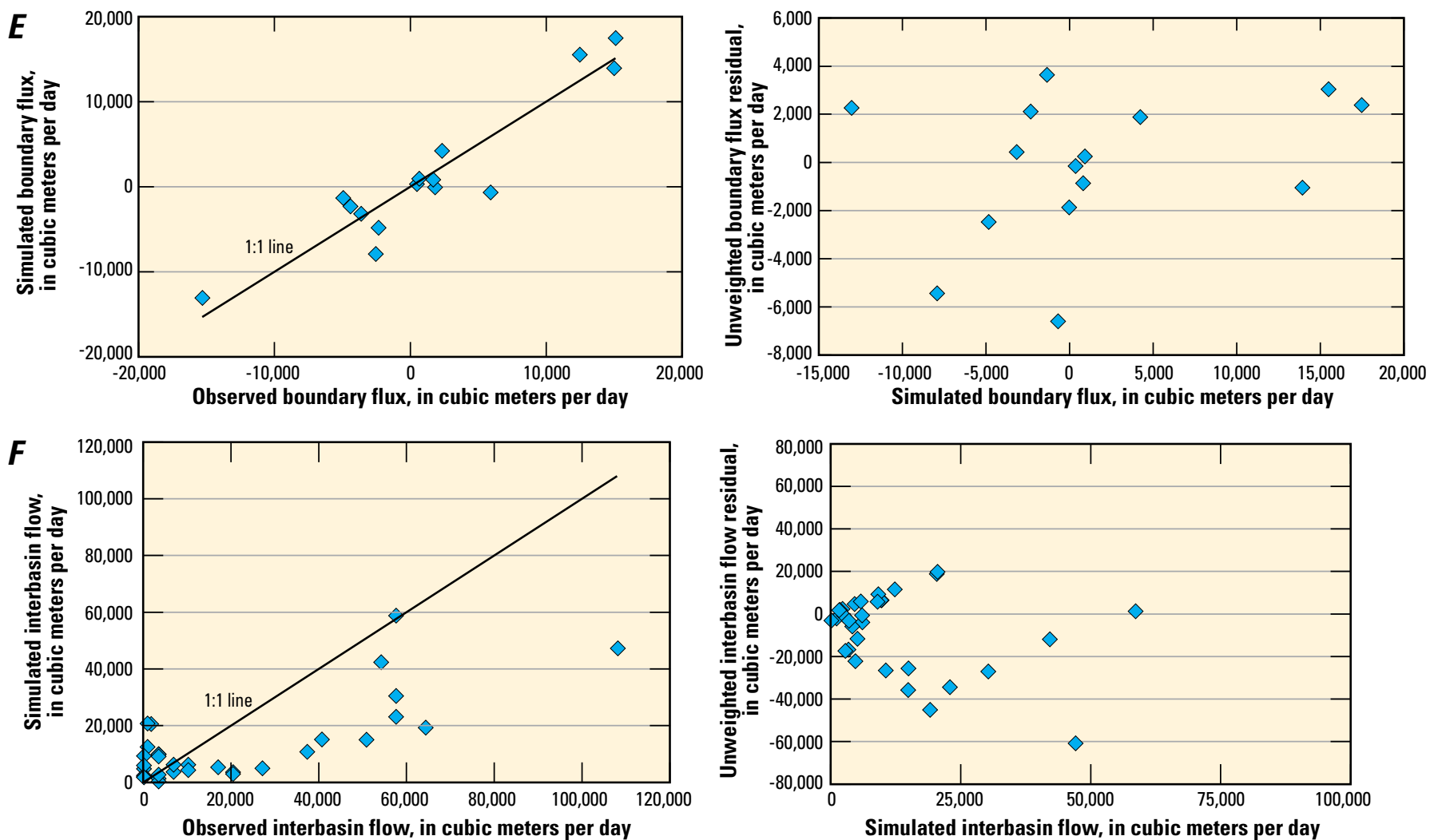

Figure 18. Observed/prior-information (x-axis) versus simulated (y-axis) values for $A$, steady-state hydraulic head, $B$, transient hydraulic-head change, $C$, vertical hydraulic-head difference, $D$, steady-state discharge, $E$, steady-state boundary flow, and $F$, steadystate interbasin flow. To the right of each figure is the simulated ( $x$-axis) versus unweighted residual ( $y$-axis) for the observation/priorinformation types.-Continued

Discrepancies between the simulated and observed hydraulic heads may be caused by assuming that pumping is constant during each calendar year or from unknown pumping. For some areas, the match between simulated and observed values likely could be improved with better estimates of the quantity and temporal distribution of pumping. For wells in the Amargosa Desert and Penoyer Valley, the observed hydraulic heads began declining in the 1960s and 1970s, respectively (fig. 21), and these declining trends were generally matched by simulated hydraulic heads.

\section{Water Budgets}

The simulated water budgets for DVRFS v. 1.0 for the steady-state pre-pumping stress period and for transient stress period 86 (representing year 1998) are presented in Faunt, Blainey, and others (2010, fig. F-39, table F-18). Simulated water-budget components from DVRFS v. 2.0 for stress period 86 are shown in table 8 and were compared to equivalent water-budget components from DVRFS v. 1.0. The differences are for a discrete point in time, but exemplify some of the changes in the DVRFS v. 2.0 model. For example, in stress period 86 , pumping (combined with irrigation return flow) is 16 percent less than in DVRFS v. 1.0. Although in some years recharge from precipitation is greater in DVRFS v. 2.0, in this particular stress period recharge is 10 percent less than in DVRFS v. 1.0. The overall RMSE is better than that in DVRFS v. 1.0; for DVRFS v 1.0, the RMSE for combined hydraulic-head, hydraulic-head change, drain, and boundaryflow observations/prior-information was 1,351.2, whereas for DVRFS v. 2.0, it was 224.2 (table 8). Overall, the fit in DVRFS v. 2.0 is slightly better than that in DVRFS v. 1.0.

Figure 22 shows the simulated water budget for the steadystate and transient stress periods for the entire simulation period of DVRFS v. 2.0. This figure is similar to figure F-39 in Faunt, Blainey, and others (2010) for DVRFS v. 1.0. The most noticeable difference between the simulated water budgets is that recharge is held constant in DVRFS v. 1.0 for the transient stress periods but varies temporally in DVRFS v. 2.0.

\section{Spring Discharge and Evapotranspiration}

Model-computed discharges through the drains (representing spring discharge and ET) match fairly well (fig. 18D). These observations/prior-information are matched somewhat better than in DVRFS v. 1.0 (Faunt, Blainey, and others, 2010) 


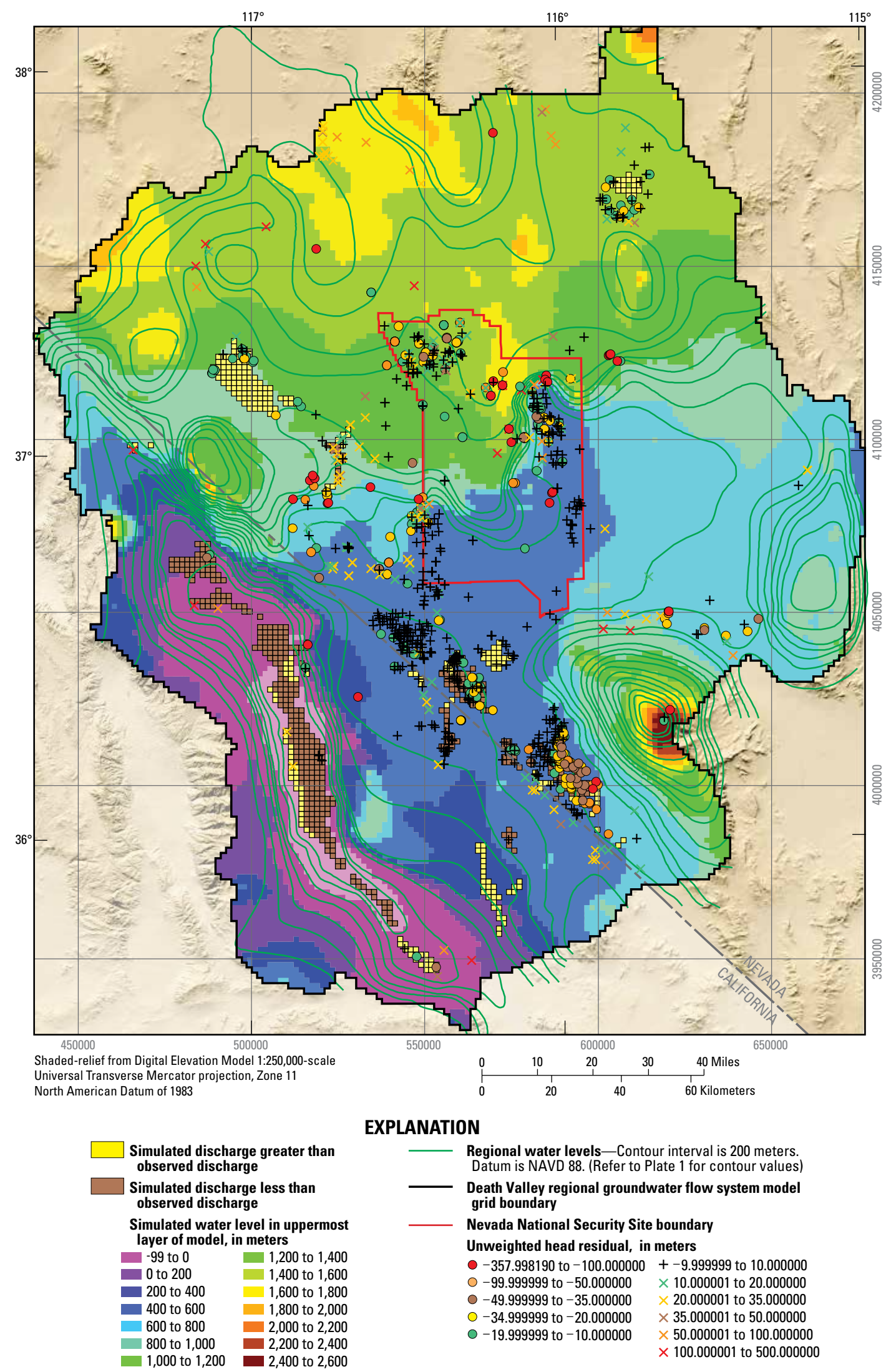

Figure 19. Well locations with steady-state hydraulic-head residuals (observed minus simulated) and simulated water-level surface in the uppermost active layer of the Death Valley regional groundwater flow system v. 2.0 model. 


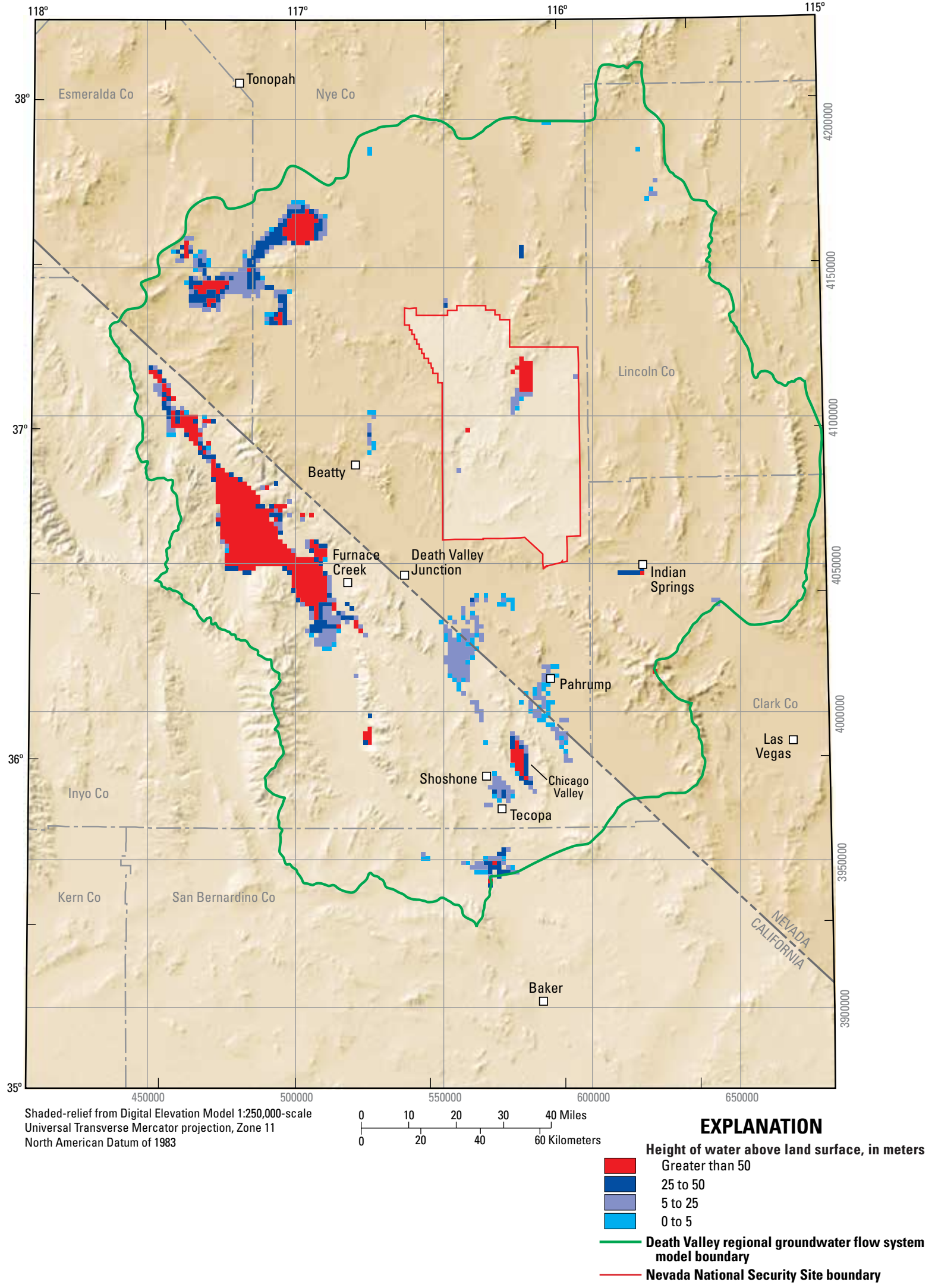

Figure 20. Locations where simulated hydraulic heads in layer 1 of the Death Valley regional groundwater flow system v. 2.0 model are above land surface. 

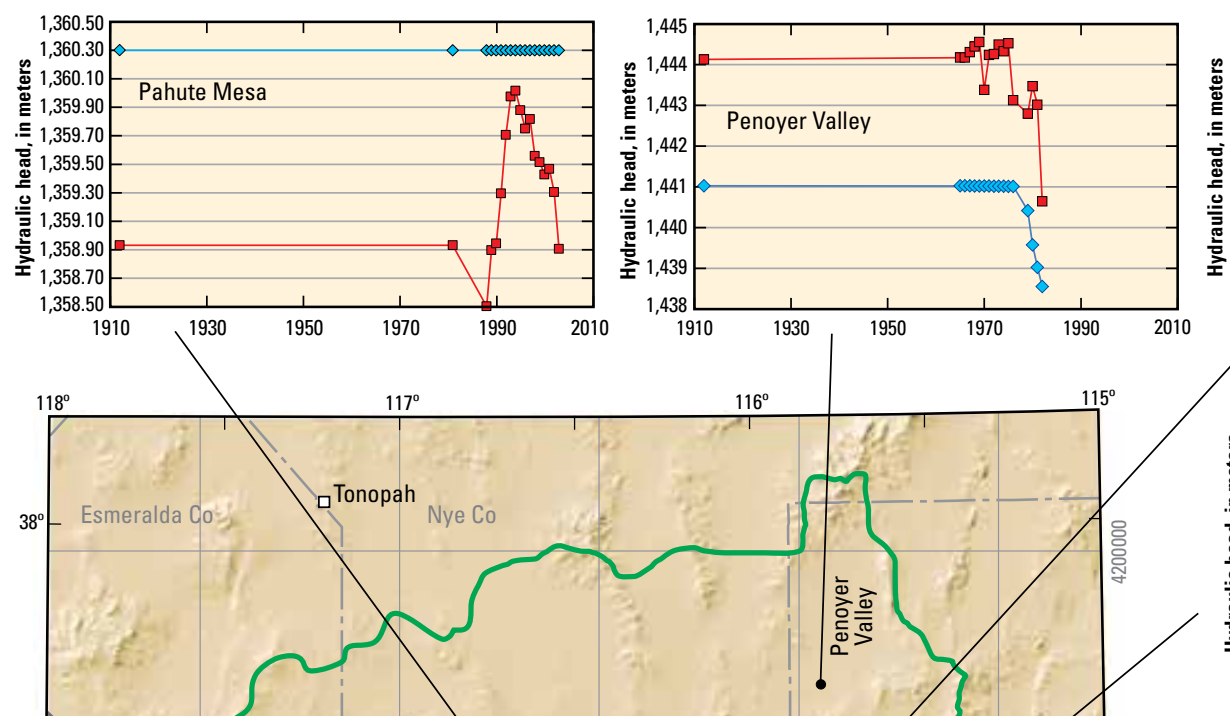

Shaded-relief from Digital Elevation Model 1:250,000-scale Universal Transverse Mercator projection, Zone 11 North American Datum of 1983
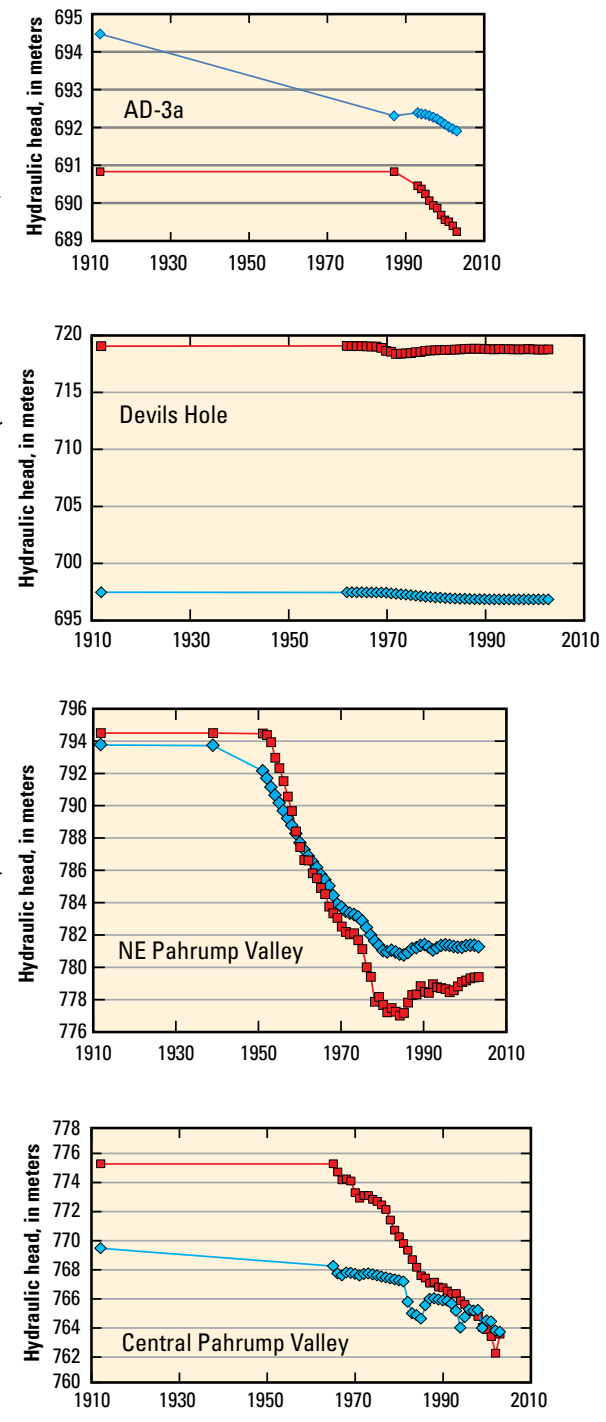

\section{EXPLANATION}

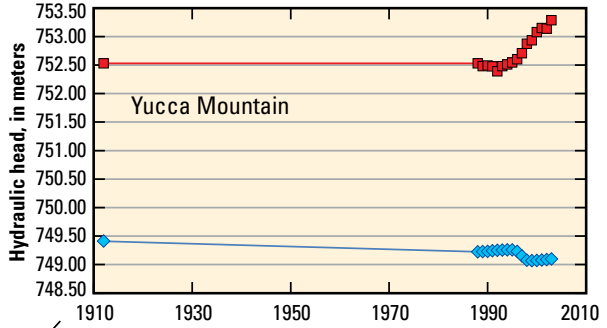

system model boundary

undwater flow

Nevada National Security Site boundary

- Hydrograph location (see map)

- Observed water levels (graphs)

- Simulated water levels (graphs)

Figure 21. Selected hydrographs showing observed and simulated water levels in pumping areas of the Death Valley regional groundwater flow system model domain. Hydrographs were selected based on length of record and regional transient response. 


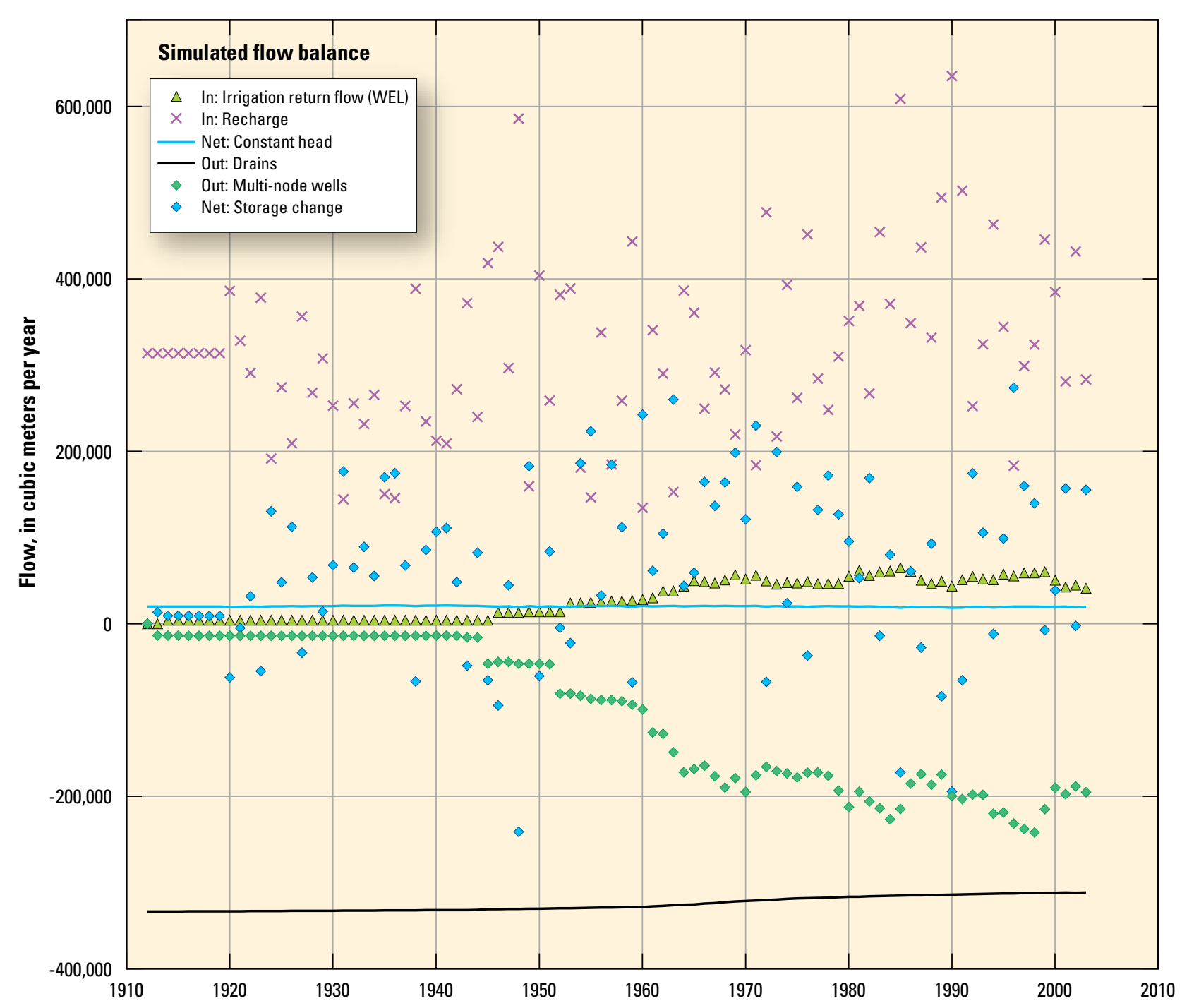

Figure 22. Total water budget for the steady-state (pre-1913) and transient (1913 to 2003) stress periods of the Death Valley regional groundwater flow system v. 2.0 model.

(table 8), with a reduction in the RMSE of 62 percent. The differences between observed/prior-information and simulated values may result from inaccuracies in the HFM, and errors in the altitudes, or in the discharge estimates.

\section{Boundary Flows}

Simulated values of flow for each boundary segment (or subsegment) differ somewhat from those reported in DVRFS v. 1.0 (Faunt, Blainey, and others, 2010), except for one small part of the Pahranagat boundary segment and a small flow near the southern model boundary. The simulated direction of flow is consistent with the observations/prior-information. The observed/prior-information flows generally match much better (a reduction of 87 percent in the RMSE for the boundary flows) than in DVRFS v. 1.0 (table 8) because these observations/prior-information are emphasized more than in DVRFS v. 1.0. The remaining differences between observed/ prior-information and simulated values may result from inaccuracies in the HFM or in the boundary-flow estimates themselves.

\section{Interbasin Flow}

Despite the relatively low weights on interbasin flow observations/prior-information, the DVRFS v. 2.0 model matches these estimates relatively well (fig. $18 F$, table 8 ). The simulated flow into Yucca Flat from the north in DVRFS v. 2.0 compared with DVRFS v. 1.0 is much lower at approximately $1,800 \mathrm{~m}^{3} / \mathrm{d}(530 \mathrm{ac}-\mathrm{ft} / \mathrm{yr})$, and almost half of the maximum estimated flow of 3,600 m³ $/ \mathrm{d}(1,000 \mathrm{ac}-\mathrm{ft} / \mathrm{yr}$ ) (Winograd and Thordarson, 1975; Harrill and others, 1988). Model-computed flows between hydrographic areas 144, 145, and 146, and 227A and 226 deviate the most from estimates and are most likely related to uncertainty in the configuration of the HGUs in this region. Model-computed flows between hydrographic 
areas 229 and $227 \mathrm{~A}$, and $158 \mathrm{~A}$ and $169 \mathrm{~A}$ are opposite in direction to observations/prior-information. The interbasin flow between these basins was assumed to be zero, based on Harrill and others (1998). The relative flows are somewhat small (less than $10,000 \mathrm{~m}^{3} / \mathrm{d}$ ) and likely reflect uncertainty in the hydrogeology and interbasin flow estimates for these hydrographic areas.

\section{Transmissivity and Hydraulic Conductivity}

Simulated transmissivity values were calculated at the completion of the calibration and compared with the priorinformation values of transmissivity (appendix 2). A majority of the simulated values are within one order of magnitude of the prior-information value. Most simulated values are within one to two orders of magnitude of the prior-information field value. Compared to the spatial extents of hydraulic-conductivity zones used in this regional model, the spatial extents of the aquifer system influenced by the aquifer tests represent much smaller, relatively localized areas. The hydraulic-conductivity zones represent much greater volumes of hydrogeologic material than that influenced by the aquifer tests and encompass much more variability than the aquifer tests.

Figure 23 shows a comparison of the 116 prior-information transmissivities from pumping tests and the simulated transmissivities in the model. Twenty-four simulated values (21 percent) are more than two orders of magnitude different than the prior-information values, with most of them biased lower than the prior-information values. Ninety-two of the simulated values are within two orders of magnitude of the prior-information values (79 percent). Fifty-eight simulated values (51 percent) are within one order of magnitude of the prior-information values. Figure 23 also shows that the simulated values maintain the same relative increasing trend with increasing prior-information transmissivity values.

The most severe mismatch between prior-information values and simulated values is in the Tertiary volcanic rocks in the vicinity of Yucca Mountain and the LCA. The Tertiary volcanic-rock HGUs are the most abundant volumetrically represented HGUs in the prior-information transmissivity data.

Belcher and others (2001) presented a range of $3 \times 10^{-8}$ to $830 \mathrm{~m} / \mathrm{d}$ (11 orders of magnitude) in horizontal hydraulic conductivity for all HGUs, whereas DVRFS v. 2.0 has a range of $1 \times 10^{-7}$ to $150 \mathrm{~m} / \mathrm{d}$ (10 orders of magnitude), including the results of the decay of horizontal hydraulic conductivity with depth. Compared to field-measured hydraulic-conductivity estimates (Belcher and others, 2001), estimated parameter values are reasonable and provide a good model fit for DVRFS v. 2.0 .

Figure 24 shows the bulk transmissivity of all model layers, presenting areas of generally higher permeability and lower permeability based on the entire thickness of the model for both DVRFS v. 1.0 and v. 2.0. Because this figure displays lumped transmissivities for the entire model thickness, it is biased toward the transmissivities that occur in the lower, thicker layers and masks the detail of the transmissivities in the upper layers. In general, figure 24 shows that DVRFS v. 2.0 has an overall lower transmissivity range than DVRFS v. 1.0. In addition, DVRFS v. 2.0 appears to match the HGU configuration better than DVRFS v. 1.0. Appendix 1 shows some significant changes in the values of the horizontal hydraulic-conductivity parameters that were assigned to zones in the models (while the configuration of the zones is largely unchanged). The differences between the transmissivity distributions are most likely a reflection of using a temporally

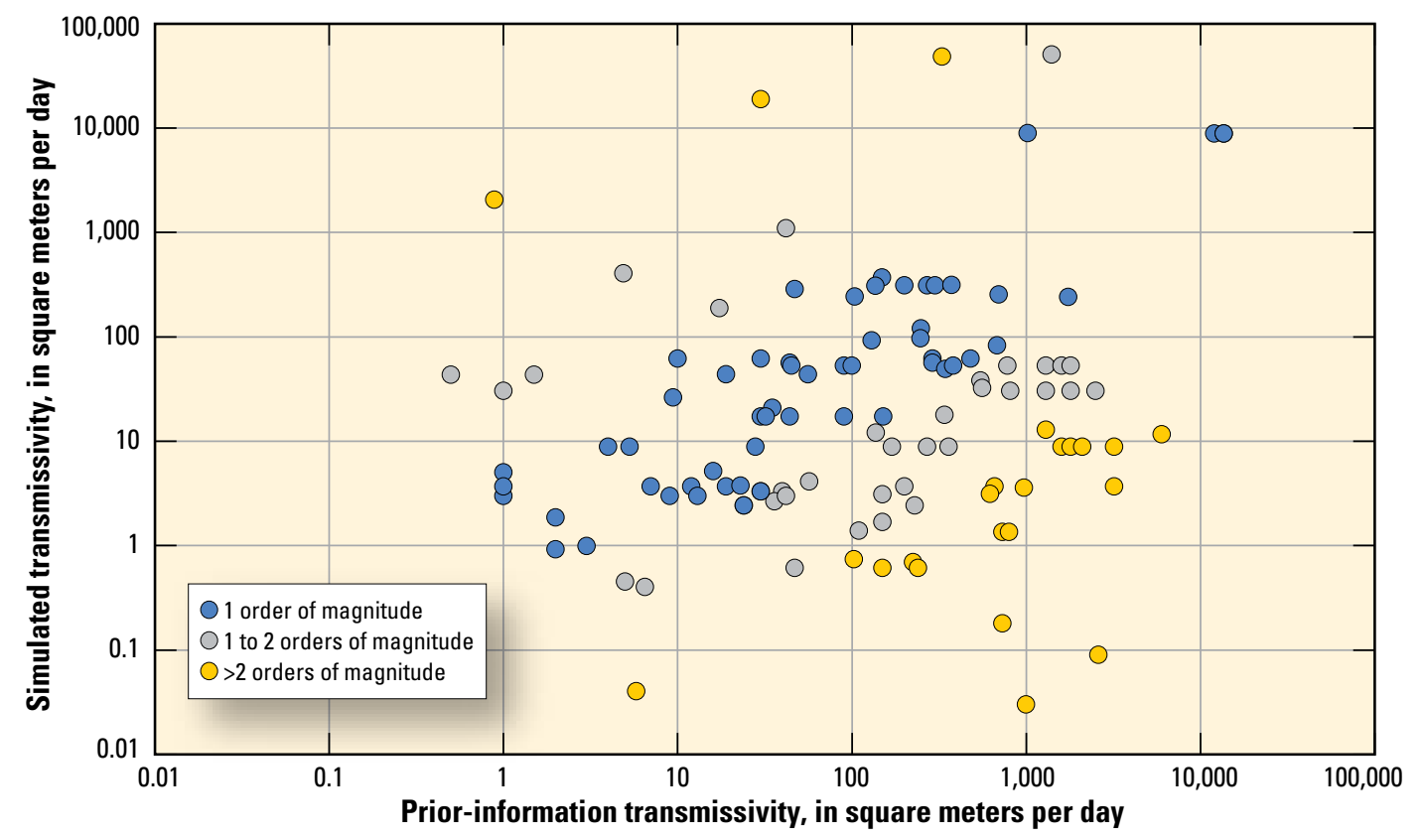

Figure 23. Relation between prior-information transmissivity and simulated transmissivity in the Death Valley regional groundwater flow system v. 2.0 model. 


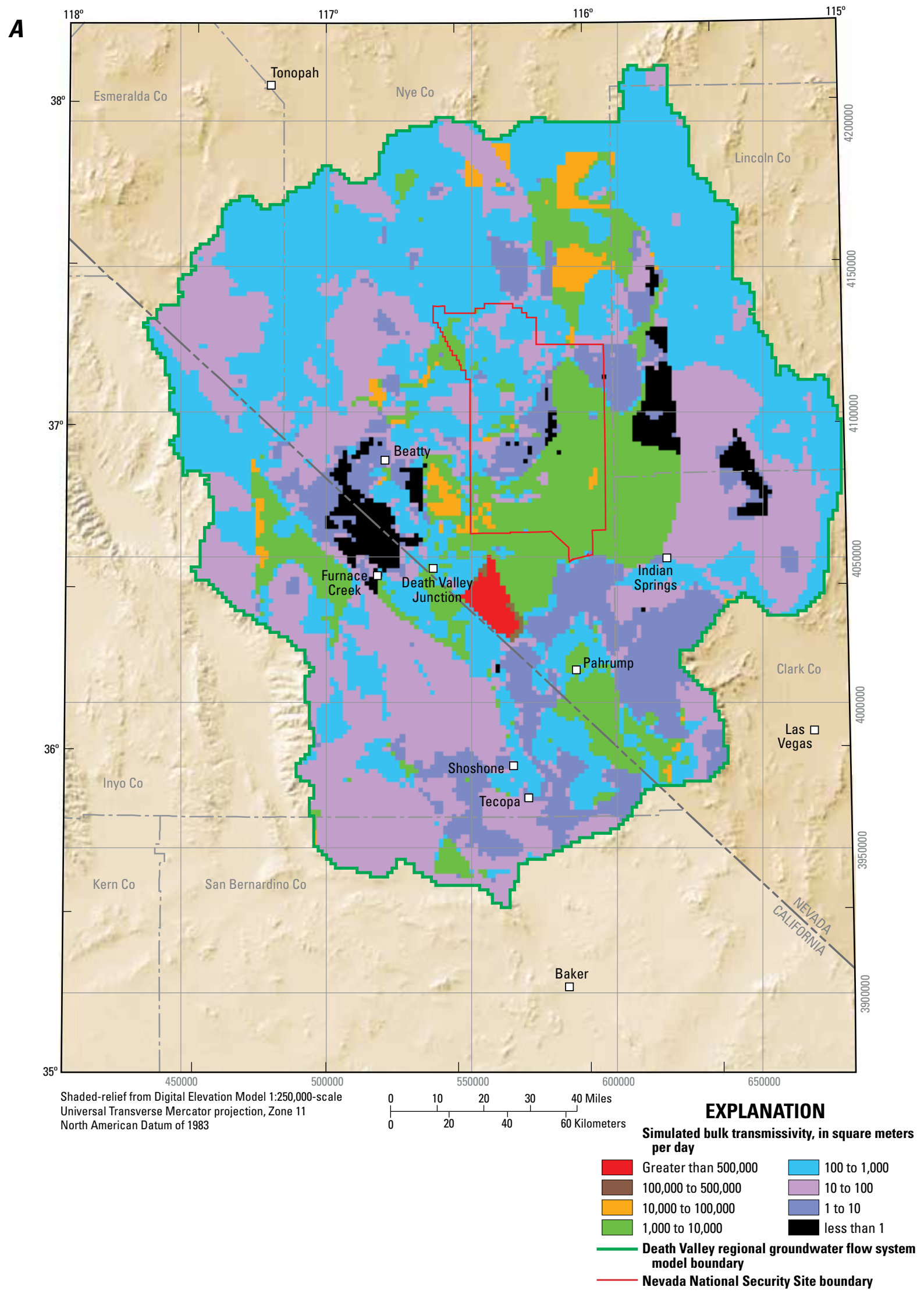

Figure 24. Bulk transmissivity for all model layers in the Death Valley regional groundwater flow system $A$, v. 1.0, and $B$, v. 2.0 models. 
$\boldsymbol{B}$

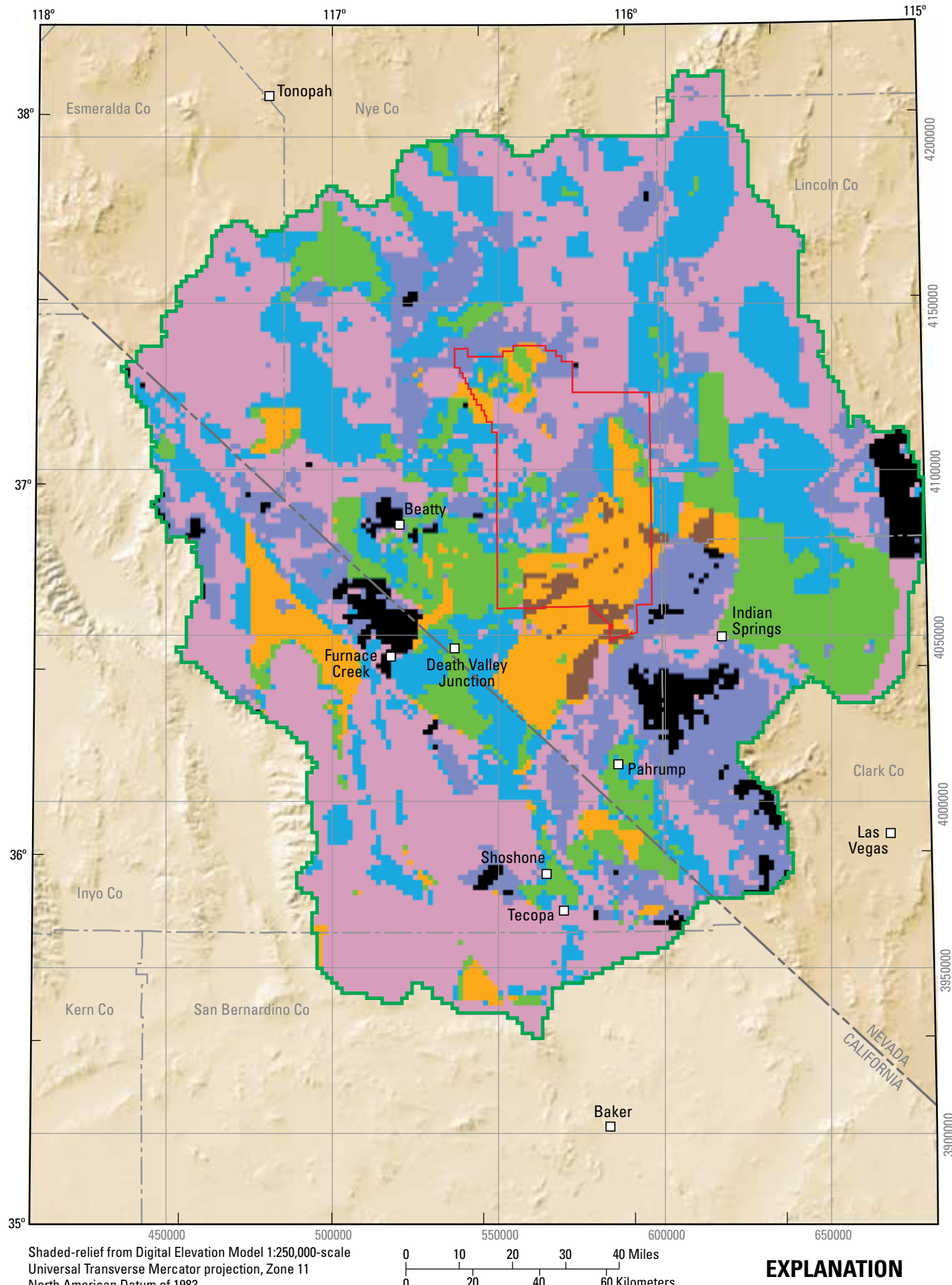

Universal Transverse Mercator projection, Zone 11

North American Datum of 1983

Simulated bulk transmissivity, in square meters per day

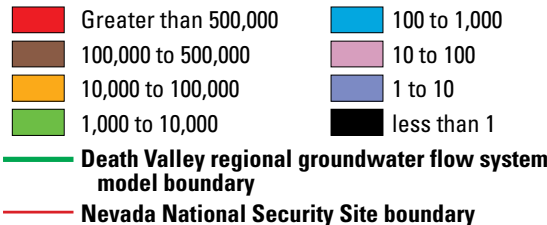

Figure 24. Bulk transmissivity for all model layers in the Death Valley regional groundwater flow system $A$, v. 1.0, and $B$, v. 2.0 models.-Continued 
varying recharge. In DVRFS v. 1.0, recharge was the most sensitive parameter, similar to that in DVRFS v. 2.0. It is likely that changing this sensitive parameter to vary with time in DVRFS v. 2.0 caused the changes in hydraulic conductivity, resulting in the differences observed between the model versions presented in figure 24 .

\section{Sensitivities}

Most of the parameters estimated during model calibration were related to hydraulic conductivity (horizontal hydraulic conductivity, horizontal-flow barriers, drain conductances, vertical anisotropy, and depth decay) (fig. 25 and appendix 1). In addition, a number of pilot points were added to better quantify storage properties for the transient simulation (appendix 1). Of the more than 500 parameters, all were estimated in the combined steady-state and transient simulation. At times during the calibration process, some of the defined parameters were not estimated because they were relatively insensitive at that point of the calibration. Sensitivity was measured by using composite-scaled sensitivities (CSS) that allow comparisons of parameters of different units by scaling them to obtain quantities with the same units. CSS present the amount of information that observations provide to estimate the individual parameter (Hill and Tiedeman, 2007). Like DVRFS v. 1.0, recharge and depth decay of horizontal hydraulic conductivity are some of the most sensitive parameters in DVRFS v. 2.0, although some volcanic-rock and basin-fill hydraulic-conductivity, vertical anisotropy, and storage parameters are also among the most sensitive parameters.

\section{Parameter Correlation}

Parameter correlation coefficients (PCC) were used to evaluate whether model parameters could be estimated uniquely by regression (Hill and Tiedeman, 2007, p. 53). A PCC with an absolute value close to 1.00 indicates that the two parameters involved likely cannot be estimated uniquely. Generally, absolute values greater than 0.95 are cause for concern, but values as small as 0.85 can affect the uncertainty of parameter estimates.

Of the more than 500 parameters only 4 had PCCs greater than 0.95 , all of them pilot points. All of these sets (parameter pairs) are negatively correlated, meaning that as one parameter is increased the other will decrease, and all of these parameters have relatively low sensitivities, less than $1 \times 10^{-3}$. The correlation of these four sets of parameters may not be able to be uniquely estimated. Two of the best most highly correlated parameter sets were for hydraulic conductivity in the basinfill deposits in northwest Pahrump Valley, and two of the sets were for pilot point specific-yield parameters occurring in the basin-fill deposits near Indian Springs, Nevada:

\footnotetext{
kvf_18 and kvf_22: -0.98

kvf_24 and kvsu_u_24: -0.99

pp_ss88 and pp_ss92: -0.99

pp_ss91 and pp_ss97: -0.97
}

\section{Hydrologic Features}

The main hydrologic features represented in DVRFS v. 1.0 are simulated in DVRFS v. 2.0. Specific features that are important include the following:

1. The vertical aspect of the flow system is simulated with downward hydraulic gradients in recharge areas and upward hydraulic gradients in discharge areas.

2. The water-level surface trough on Pahute Mesa (fig. 1), although subdued in the simulation (fig 19).

3. The generally west-to-east hydraulic gradient in the volcanic rocks at Yucca Mountain (figs. 1 and 19).

4. The upward hydraulic gradient from the carbonate-rock aquifer at Yucca Mountain.

5. The downward hydraulic gradients in recharge areas of the Spring Mountains and parts of Pahute Mesa, and upward hydraulic gradients in discharge areas in Pahrump Valley and Ash Meadows (fig. 1).

\section{Evaluation of Selected Areas}

The simulation of the conceptual hydrologic model presented in Faunt, D'Agnese, and O'Brien (2010) was evaluated in the following seven selected areas, based on the potential use of the numerical model by cooperating agencies: (1) Pahute Mesa, (2) Yucca Flat, (3) the Eleana Range, (4) Bare Mountain, (5) the southern Funeral Mountains, (6) southern Pahrump Valley, and (7) Chicago Valley (fig. 1). An evaluation was also done on the deep part of the flow system in the model (layers 15 and 16).

\section{Pahute Mesa}

DVRFS v. 2.0 accurately depicts underflow from the north of and beneath Pahute Mesa (fig. 1) at the NNSS. The potential for underflow beneath Pahute Mesa from the north is reflected in water-level maps published by IT Corporation (1996c), Laczniak and others (1996, pl. 1), D'Agnese and others (1998), Bedinger and Harrill (2010), and plate 1. Bedinger and Harrill's (2010) map represents the deep regional flow potential (the carbonate-rock aquifer). The lower VSU and the OVU in these areas act as water-bearing units, allowing underflow at Pahute Mesa. Cross sections H-1 and H-16 of Sweetkind and others (2001) show these HGUs existing beneath and extending to the north of Pahute Mesa. 


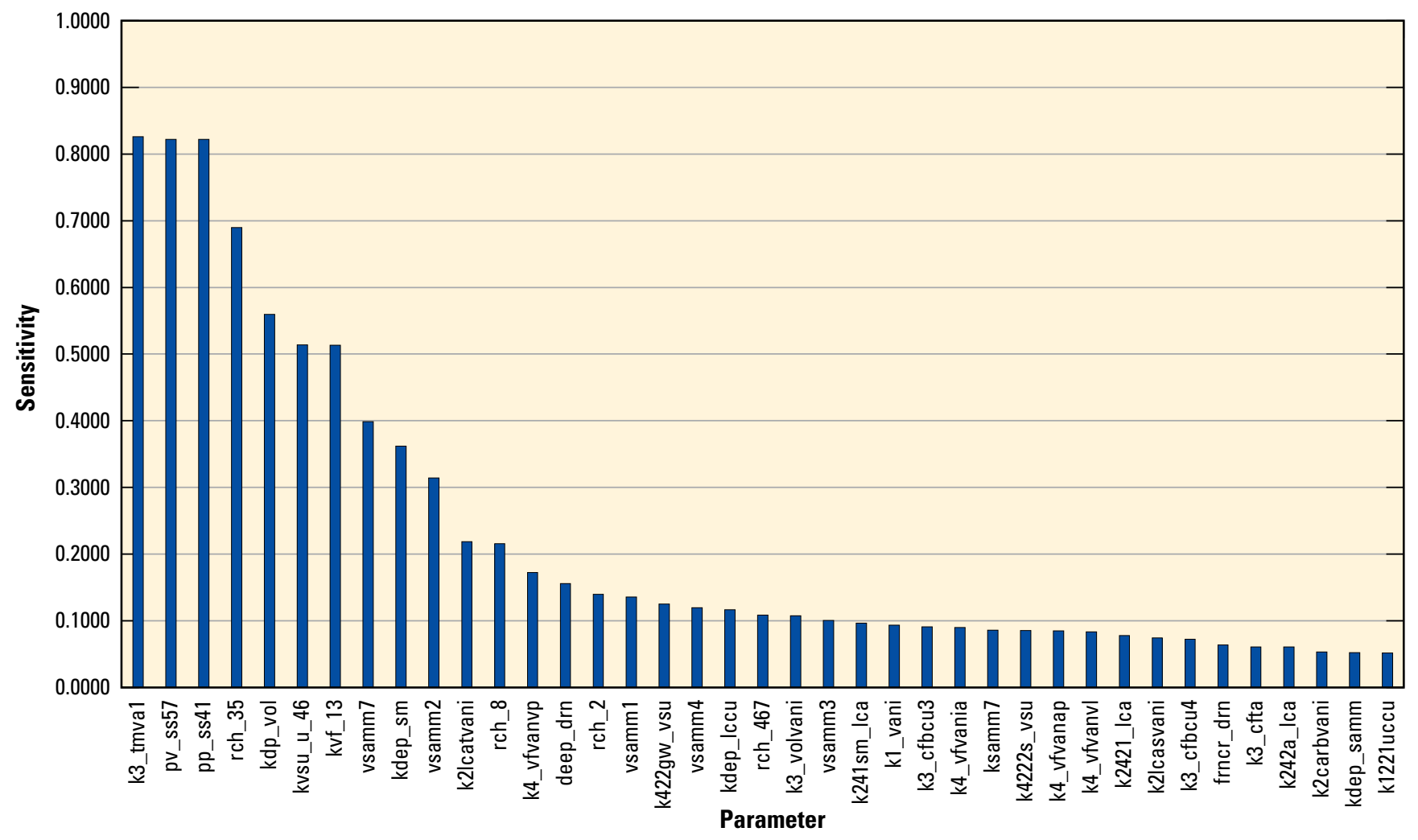

Figure 25. Composite-scaled sensitivities for all parameters with values greater than $3.5 \times 10^{-2}$ in the Death Valley regional groundwater flow system v. 2.0 model. Parameter names are listed in appendix 1.

\section{Yucca Flat}

DVRFS v. 2.0 contains a relatively high transmissivity zone running along the approximate center of Yucca Flat (fig. 1) at the NNSS that results from a thick LCA (Sweetkind and others, 2001) (fig. 24). Fenelon and others (2012, fig. 18) describe a similar transmissive zone inferred from an aquifer test. This transmissive zone is presumed to be along the Yucca Fault in Yucca Flat. Although the DVRFS v. 2.0 transmissive zone and the Fenelon and others (2012) transmissive zone roughly correspond spatially, the mechanism producing the respective highly transmissive zones differs (thick sequence of LCA versus presumed fault effects). The approach of using a digital HFM to distribute hydraulic properties in the flow model domain, along with the large grid cell size, did not allow the inclusion of the Yucca Fault transmissive zone except as a relatively small and localized high hydraulic-conductivity zone.

Changes in the configuration of HGUs in northern Yucca Flat (described in the "Hydrogeologic Framework Model and Structure Revisions" section of this report) resulted in greatly reducing the simulated flow into Yucca Flat from the north. The flow into northern Yucca Flat matches more closely previously published literature values than in DVRFS v. 1.0. This is an improvement over DVRFS v. 1.0 and more closely represents the hydrogeologic conceptual model for northern Yucca Flat (Faunt, D'Agnese, and O'Brien, 2010).

\section{Eleana Range}

DVRFS v. 2.0 simulates accurately the hydrologic system in the vicinity of the Eleana Range (fig. 1) at the NNSS. Tracks for a steady-state solution of particle migration show relatively few particles (compared to the vast majority of the particles migrating to the west and south of Pahute Mesa underground test areas) moving across the relatively lowpermeability hydrogeologic units of the Eleana Range (Karl Pohlmann, 2014, Desert Research Institute, written commun.). Low-permeability materials can allow the passage of water under a hydraulic gradient given a substantial amount of time, as would occur in a steady-state solution of particle migration. Winograd and Thordarson (1975, pl. 1) show the potential for groundwater flow through the Eleana Range to Yucca Flat. DVRFS v. 2.0 simulates approximately $320,700 \mathrm{~m}^{3} / \mathrm{yr}(260$ ac-ft/yr) flowing through the Eleana Range. At least an order of magnitude more groundwater $\left(3,500,000 \mathrm{~m}^{3} / \mathrm{yr}\right.$ or 2,800 ac-ft/yr) flows to the west from Pahute Mesa.

\section{Bare Mountain}

Like the Eleana Range, a few DVRFS v. 2.0 steady-state tracks of particles originating from Pahute Mesa (Karl Pohlmann, 2014, Desert Research Institute, written commun.) cross into and through Bare Mountain (fig. 1) near Beatty, Nevada, indicating the potential for a very small amount of 
flow through Bare Mountain. Bare Mountain consists predominantly of carbonate rock (Sweetkind and others, 2001; Fenelon and others, 2010), which could potentially allow some flow through it. This simulated result does not contradict the accepted conceptual hydrogeologic model in this part of the NNSS.

\section{Southern Funeral Mountains}

DVRFS v. 2.0 is consistent with the accepted hydrogeologic interpretations of groundwater flow from Ash Meadows to the Furnace Creek springs through the southern Funeral Mountains (fig. 1). The existence of a high transmissivity zone in the southern part of the Funeral Range (figs. 1 and 24) allows groundwater to move along this flowpath. Groundwater flow through the southern Funeral Range has long been an established concept on the basis of hydrogeology (Fridrich and others, 2012), configuration of the potentiometric surface (Bredehoeft and others, 2008), spring chemistry (Steinkampf and Werrell, 2001), groundwater chemistry and isotopic data (Belcher and others, 2009), and numerical modeling (Inyo County Yucca Mountain Repository Assessment Office, 2007; Bredehoeft and others, 2008).

\section{Southern Pahrump Valley}

The model simulates localized zones of high transmissivity in the southern part of Pahrump Valley (figs. 1 and 24). This results from the presence of areas of thick LCA beneath Pahrump Valley and the adjacent Nopah Range (fig. 1); the thickness of the LCA changes significantly over small lateral distances (Sweetkind and others, 2001). It is this variation in thickness in this structurally complex area that forms the localized zones of high transmissivity in the southern part of Pahrump Valley. These transmissive zones also facilitate flow through the Nopah Range into Chicago Valley.

\section{Chicago Valley}

As mentioned in the "Evaluation of Estimated Parameters" section of this report, there are some areas in DVRFS v. 2.0 where hydraulic heads are simulated to be above land surface (fig. 20). One of these areas is on the west side of Chicago Valley (figs. 1 and 20). These high hydraulic heads are the result of groundwater flow being impeded by the LCCU, restricting flow through the Resting Spring Range (Sweetkind and others, 2001). The geometry of the LCCU and LCA in the Resting Spring Range is poorly understood with respect to groundwater flow through these units. If sufficient thickness of the LCA actually exists in the range, groundwater could more easily flow from Chicago Valley into the Lower Amargosa Valley (fig. 16), which would be in agreement with the conceptual flow model (Faunt, D'Agnese, and O'Brien, 2010). Incorporating this hydrogeologic interpretation in the HFM would likely eliminate or greatly reduce this area of hydraulic heads above land surface in the model.

\section{Flow at Depth}

The upper model layers are used to simulate relatively shallow flow primarily through basin-fill sediments and volcanic rocks, and through adjacent mountain ranges. The lower layers predominantly simulate deep flow through the regional carbonate-rock aquifer beneath the basin fill and mountain ranges. The uppermost model layer (layer 1) is thick where low-permeability rocks, groundwater mounding, and (or) steep hydraulic gradients are present. It is thickest in the Spring Mountains and parts of the Grapevine Mountains. The thickness of model layer 16 varies and can extend as deep as $4,000 \mathrm{~m}$ below sea level; it is thickest in the Spring Mountains and in isolated areas in the northeastern part of the model domain. With the exception of model layer 1, which has some thicker parts locally, model layer thickness generally increases with depth. This allows greater resolution at the top of the flow model where more hydrologic and geologic data are available.

Because flow through the carbonate-rock aquifer discharges at the high-volume high-temperature springs in the area, it is necessary to simulate groundwater flow through a large part of this aquifer to these regional springs. The conceptual model posits that warm water, large volume discharge springs emanate from the LCA. The deep_drn conductance accounts for flow to springs and ET areas that are simulated as flow from depth within the drain cell located at the shallowest occurrence of the LCA. Simulated flow from the deep drains is $77,000 \mathrm{~m}^{3} / \mathrm{d}$ compared to the measured flow of $70,000 \mathrm{~m}^{3} / \mathrm{d}$. This relatively good match between measured and simulated values indicates an accurate representation of the conceptual model of deep flow from the LCA to the ground surface in the form of the warm temperature, high volume springs. Flow between the deepest layers of the model (layers 15 and 16) at steady-state is $3,600 \mathrm{~m}^{3} / \mathrm{d}$ with a downward vertical gradient. Most of this flow appears to exit from layer 16 through the constant head cells at the model boundary. 


\section{Appropriate Uses}

Similar to DVRFS v. 1.0, DVRFS v. 2.0 was constructed to be used as a groundwater management tool by a variety of cooperators and stakeholders. Because the DVRFS model was constructed to simulate regional-scale groundwater flow, it can be used to answer questions regarding issues at that scale. It may be used to (1) test hydrogeologic conceptual models, (2) evaluate the effects of changes in system flow, regardless of whether the changes are natural or human induced, (3) provide a technical basis for decisions on the quantity of water available for development activities across the model domain, including the NNSS, (4) determine the potential effects of increased offsite water use on NNSS water supplies, (5) provide a framework for determining effective source plume, ambient trend, and point-of-use groundwater-quality monitoring locations, (6) provide the boundary conditions for modeling of the UGTA CAUs on the NNSS, (7) facilitate the development of a refined management tool for groundwater resources in the Death Valley region, and (8) provide a context for constructing locally refined grids for more detailed numerical models, with an emphasis on the southern part of the Amargosa Desert.

\section{Model Limitations}

As is the case with all groundwater flow models, the DVRFS v. 2.0 is a simplification of the physical system and has corresponding limitations in model resolution and accuracy, and how the model can be used. The following limitations are

- spatial discretization

- hydrogeologic framework

- confined system simulation

- transmissivity and depth decay of hydraulic conductivity

- recharge from precipitation

- boundary flows

- pumping and irrigation return flow

- evapotranspiration

- temporal discretization

\section{Spatial Discretization}

Although the 1,500 x 1,500-m horizontal cell size of the flow model grid is appropriate to represent regional-scale conditions, a greater resolution (smaller cell size) could potentially improve simulation accuracy, particularly in areas of geologic complexity. The model is not appropriate to use for assessing local-scale issues, such as the absolute value of drawdown in a particular location such as Devils Hole, or even the depth to water at a particular location. The large grid cells tend to generalize important local-scale complexities that affect regional hydrologic conditions. To represent local-scale variability, smaller grid cells throughout the model, or local refinement around selected features or in critical areas in the model domain, would be required.

The large grid size also tends to dampen pumping effects because the cell size is large relative to the well bore. In onelayer quasi-homogeneous systems a correction can be calculated (Bennett and others, 1990), but it is difficult to simulate wells completed in multiple layers with the heterogeneity common to the DVRFS. Because of this, simulated transient drawdown may not match observed drawdown accurately. To represent more local dynamics, smaller grid cells throughout the model (or local refinement around selected features or in critical areas in the model domain) may be required. For example, because of the complex hydrogeologic system in Pahrump Valley, despite the addition of pilot points in the Pahrump Valley alluvial units, a more detailed model may be needed to simulate hydraulic-head changes more accurately.

\section{Hydrogeologic Framework}

The ability of the numerical model to simulate flow accurately depends on the accuracy and representation of the hydrogeologic framework. Limitations exist in DVRFS v. 2.0 because of the difficulties inherent in the interpretation and representation of the complex geometry and spatial variability of the heterogeneous hydrogeologic materials and geologic structures in the hydrogeologic framework, and because of the application of that framework to a 1,500-m model cell size. Small-scale changes in rock type and material properties cannot be represented, and important features may be missed completely at this scale. A single preferred hydrogeologic framework is simulated; alternative interpretations were not simulated but are possible. Uncertainty in the configuration of the hydrologic units at the basin boundaries of HAs 144, 145, and 146 likely causes the large deviations from model computed and estimated interbasin flow.

\section{Simulation as a Confined System}

Numerical groundwater-flow models of the DVRFS and the Great Basin have long been simulated as confined flow systems to reduce computational burdens and facilitate the timeliness of calibration runs (IT Corporation, 1996a; D'Agnese and others, 1997; D'Agnese and others, 2002; Faunt, Blainey, and others, 2010; Brooks and others, 2014). Simulation of groundwater flow in unconfined systems can be difficult because of nonlinearities in the governing equations owing to the dependence of transmissivity on head and the effects of wetting and drying of model cells with changes in head and non-linear boundary conditions. Considerable time savings (both in 
project schedule and computational time) can be realized without sacrificing accurate hydraulic-head and flow solutions by simulating the entire system as a specified thickness (confined) approximation (Sheets and others, 2014). Simulating confinedflow conditions in all model layers assumes that all the layers are fully saturated and that the transmissivities are independent of head.

Sheets and others (2014) indicate only 4-percent error in calculated drawdowns when using a specified thickness solution, even when drawdowns approach 20 percent of the saturated thickness. Faunt and others (2011) indicate that, specifically for the DVRFS v. 1.0 numerical model, the drawdown in the specified thickness solution is similar to that of an unconfined solution when the drawdown limiting capability in the Multi-Node Well (MNW) package is used.

\section{Use of Idealized Potentiometric Surface as Top of Model}

As was done in DVRFS v. 1.0 (Faunt, Blainey, and others, 2010) and in the Great Basin carbonate and alluvial aquifer system model (Brooks and others, 2014), initially, the top of the model (top of layer 1) was set to the idealized regional potentiometric surface described in the "Modification of the Estimated Regional Potentiometric Surface" section of this report. As calibration proceeded, the simulated heads in layer 1 from the previous run were used as the top of the model in an iterative fashion. Use of the idealized regional potentiometric surface to represent initial starting pre-development, steady-state heads for confined-flow simulations in model layer 1 is limited by three principal factors: (1) the data used to produce the idealized regional potentiometric surface lack complete spatial coverage, (2) recent water-level measurements at wells assumed to be unaffected by pumping are used, and (3) heads for the LCA are largely determined from the land-surface altitude at the location of regional springs.

\section{Hydraulic Parameters}

There are several limitations to DVRFS v. 2.0 with respect to how hydraulic properties (hydraulic conductivity, transmissivity, and storage) are implemented. These include the (1) assumption of equivalent porous media, (2) use of zones to simulate the hydraulic-conductivity field, (3) use of transmissivity as observations/prior-information, (4) effects of temperature and salinity, and (5) use of depth decay.

DVRFS v. 2.0 uses an equivalent porous media approach to simulate fractured media such as the volcanic-rock units and the LCA. MODFLOW-2005 is a porous media code and does not explicitly simulate discrete fracture networks. It was assumed that, given the regional scale of the model and its intended application to regional- and subregional-scale groundwater flow evaluations, the representative hydraulic behavior of the fractured hydrogeologic units is analogous to that of porous media at these scales. This may be useful for groundwater flow, but care should be taken if the model is used for contaminant transport, which might be more appropriately simulated by using a discrete fracture network.

The delineation of zones of hydraulic conductivity and the selection of faults to simulate with the HFB package (Hsieh and Freckleton, 1993) were selected to match the observations/prior-information. It is possible that different zone boundaries could be selected that would provide a similar or better model fit and that additional zones exist that are not simulated because geologic or hydrologic data are not available to delineate them. It is also possible that faults that are not simulated with the HFB package could act as similar barriers to groundwater flow, but the water-level data are not available to delineate these areas.

As is the case with regional models in general, the transmissivity estimates from pumping tests were considered to be point values and are only useful as a guide for the calibration rather than a rigorous, accurately located target value. Heterogeneity exists and the use of zones assumes that an effective average for the HGUs in the zone can adequately simulate porous media flow processes within the zone. This approach of using transmissivity as prior-information may not be appropriate with the use of zones because of the great differences in the volume of aquifer material influenced during a pumping test and the large aquifer volumes simulated in an HGU.

The effects of temperature and salinity on fluid (water) density, especially at depth, were not simulated in this numerical model. MODFLOW-2005 does not allow for these effects on the groundwater flow to be simulated. Because the model is calibrated to discharge (among other observations/priorinformation), some of these effects, however, may have been accounted for. The drain conductances for Death Valley were an estimated parameter and were specifically designated as a separate parameter because of the substantial salt concentrations on the floor of Death Valley.

Intuitively, hydraulic conductivity and specific storage tend to decrease with depth as the geostatic load and effective stress increases, potentially compressing favorably oriented fractures, faults, and sedimentary units and reducing the porosity. Analyses of covariance confirmed the assumption that depth was a significant factor in the variability of hydraulic conductivity in the DVRFS (Belcher and others, 2001), but variability in hydraulic-conductivity estimates from other factors prevents a rigorous quantification of a depth decay function. The depth decay coefficient was assigned or estimated for only certain HGUs (LCCU, LCA, LCA_T1, volcanic-rock units, and basin-fill units). No attempt was made in DVRFS v. 2.0 to account for depth-dependent changes in specific storage.

\section{Deep System}

The DVRFS is an extremely complex geologic and hydrogeologic framework that juxtaposes rocks at apparently great depth in some parts of the flow system with shallow rocks in other parts of the flow system. Some of these rocks are important components of the regional flow system that must be included in any defensible model that is intended for use 
in accurately simulating regional flow within the DVRFS. For example, a deep regional carbonate-rock aquifer system that is part of the regional groundwater system is a key potential future source of water in the region and the focus of many of the concerns with respect to both a proposed radioactive waste repository at Yucca Mountain and the effects of nuclear testing and other activities at the NNSS. Other deep rocks serve as important confining units and barriers that redirect groundwater flow and give rise to spring discharge and evapotranspiration. Winograd and Thordarson $(1975$, p. 77$)$ imply that the entire thickness of the LCA may have significant groundwater movement at depths approaching the top of the hydraulic basement. The DVRFS is a 3D system and needs to be simulated in that manner; however, much of the calibration data represents at or relatively near-surface conditions. There is a decrease in the available knowledge of HGUs and structures with depth, resulting in increased uncertainty with depth.

\section{Recharge from Precipitation}

The main limitation in the representation of recharge in DVRFS v. 2.0 is the assumption that net infiltration results in regional recharge. The net-infiltration model likely overestimates recharge in many parts of the model domain because it is assumed that all infiltrating water that passes the root zone ultimately reaches the water table (Hevesi and others, 2003). This assumption ignores the possibility that infiltrating water could be diverted laterally, perched by a low-permeability layer in the unsaturated zone, or evaporated from the unsaturated zone. In general, the uncertainty of approximating potential recharge from net infiltration increases as thickness and heterogeneity of the unsaturated zone increases. There is also uncertainty as to whether the simulation period (1950 to 1999) of Hevesi and others (2003) is representative of average conditions.

\section{Boundary Flows}

Limitations in the definition of boundary flows are the result of an incomplete understanding of natural conditions. Because very little data exist in the areas defined as flow-system boundary segments, all aspects of the assigned boundary conditions are poorly known. Flow into the model domain is poorly defined and remains one of the most uncertain variables in the model. Errors in the estimates of the boundary flows can ultimately affect the amount of water available to the flow system. Greater estimates of boundary flow could result in higher water levels; lower estimates could result in lower water levels. Both of these conditions could ultimately affect the model-estimated hydraulic-conductivity field owing to nonunique solutions that satisfy the calibration targets. The use of specified constant-head boundaries to simulate the model boundary flows limits the model's effectiveness in evaluating groundwater development near the model boundary (Reilly and Harbaugh, 2004; Brooks and others, 2014).

\section{Springs and Evapotranspiration Areas}

Many discharge areas represent individual springs that are substantially smaller in area than the simulated $2.25-\mathrm{km}^{2}$ grid cell. At individual-spring scale, it is not possible to represent variations in hydraulic gradient, fault and fracture geometry, and changes in lithology in the model that influence groundwater discharge rates at a regional scale. In some cases, however, individual springs, such as Travertine, Texas, and Nevares Springs at Furnace Creek in Death Valley (fig. 1), were explicitly simulated. Discharge areas with flow rates less than $1,000 \mathrm{~m}^{3} / \mathrm{d}$ were difficult to simulate, but the discharge contributions are relatively minor given the overall volumetric budget and model scale. Because of these simplifications in representing discharge areas in the model, errors in simulation can result.

\section{Pumping and Irrigation Return Flow}

In this and previous DVRFS models, the pumping component contains a degree of uncertainty. The calibration and sensitivity analyses assume that magnitude and distribution of pumping are known. Therefore, these flows are assumed to be part of the model's structure or definition. There can be a significant amount of uncertainty associated with these flow components that can subsequently affect the model's calibration and thus, its predictions. In Pahrump Valley and the Amargosa Desert (fig. 1), unknown development and (or) unaccounted for pumping could affect drawdown simulations in these areas. Currently, there is little existing methodology for systematically addressing this type of uncertainty. Poorly matched drawdowns could be the result of this uncertainty in pumping.

Recharge to the groundwater system in the form of irrigation return flow was an estimated parameter, as it is largely unknown. In DVRFS v. 2.0, both the magnitude (irr_return) and the lag time (irr_delay) were estimated by parameters (appendix 1) and, although relatively insensitive, were 24.5 percent and 15 years, respectively. As described in the "Model Parameters" section of this report, estimates of return flow by Stonestrom and others (2003) and Harrill (1986) lend support to these model-derived values.

\section{Evapotranspiration}

The model does not simulate the complex process of ET but accounts for the groundwater discharge attributed to ET through use of the Drain package (Harbaugh and others, 2000). Evapotranspiration by native vegetation has been studied extensively. Future revisions of the DVRFS model might be improved by using a more complex ET package than is currently available instead of the Drain package. This more complex package could incorporate spatially varying parameters to simulate recharge from precipitation, soil moisture, and vegetative growth. 


\section{Temporal Discretization}

The representation of time by annual stress periods simulated in the model allows the model to address only those dynamics that change in the course of at least several years. Simulation of seasonal dynamics by use of shorter stress periods could be advantageous in accounting for the seasonal nature of irrigation pumpage. Such a simulation would require seasonal definition of hydrologic conditions.

\section{Summary}

This report describes the various aspects of the updates and revisions to the Death Valley regional groundwater flow system (DVRFS) numerical groundwater flow model, DVRFS v. 1.0, that were made to develop the new DVRFS v. 2.0 model. This includes the construction of a lithology-based hydrogeologic framework model of the southern part of the Amargosa Desert, revisions to the regional hydrogeologic framework model, updates to the model codes, updates to the pumpage and hydraulic-head data sets, extension of the simulation period to 2003, and re-calibration of the resulting regional groundwater flow model. Model input files used updated pumpage data and water-level observation data (hydraulic head, hydraulic-head changes, and vertical head gradients), along with natural groundwater discharge (springs and ET), interbasin flow, and transmissivity. The DVRFS v. 2.0 model incorporated the most recent version of the MODFLOW simulation code, MODFLOW-2005, and the parameter estimation and predictive uncertainty software, PEST, that allowed new capabilities to be utilized, including the MODFLOW LGR module.

Pumpage is a relatively small stress on the DVRFS compared to the overall flow through the system. Updates to this pumping dataset for DVRFS v. 2.0 were made to extend the simulation period from 1999 through 2003 and to use the revised agricultural pumping estimates based on new estimates of crop water use. Wells in the DVRFS typically are completed with screens that span multiple aquifers and thus, multiple layers in the model. Because of this, pumping from wells was simulated by using the Multi-Node Well (MNW) package. Drawdown was limited in MNW so that it would not drop below the bottom of the pumping interval in the well. A separate Well (WEL) package was developed to apply the irrigation return flow in the model, with the amount estimated to be about 25 percent, lagged by approximately 15 years.

The water-level database used in DVRFS v. 1.0 was revised to include regional water-level data collected from 1998 through 2003. More than 54,000 water levels measured in about 1,800 wells from 1907 to 2007 were compiled, analyzed, and characterized in the revised hydraulic-head database. Steady-state hydraulic-head observations/priorinformation and transient hydraulic-head-change observations/ prior-information were used in DVRFS v. 2.0. Most wells have less than $15 \mathrm{~m}$ of measured drawdown. Wells having drawdown greater than $15 \mathrm{~m}$ typically are in areas of concentrated irrigation use, primarily the Amargosa Desert and Pahrump and Penoyer Valleys. A modification of the estimated idealized water-level surface used in DVRFS v. 1.0 was used to initially define the top of the flow model (starting heads) and includes new water-level and spring discharge data.

DVRFS v. 2.0 was calibrated by using the Tikhonov regularization functionality in PEST, which allows for systematic inclusion of prior-information into the parameter estimation process. All model parameters were regularized; the regularization targets were based on conceptual geologic and hydrogeologic knowledge and the results of previous modeling using DVRFS v. 1.0.

The calibrated DVRFS v. 2.0 model was evaluated to assess the accuracy of simulated results. An advantage of using nonlinear regression to calibrate the model is that substantial methodology exists for model evaluation that facilitates a better understanding of model strengths and weaknesses. In order to evaluate the model, the following observations/prior-information and simulated values were evaluated: (1) hydraulic heads and hydraulic-head changes, (2) flows (including springs and evapotranspiration (ET), discharge, boundary flows, and interbasin flow), (3) the regional water budget, and (4) values of hydraulic parameter estimates and their associated sensitivities.

Steady-state hydraulic heads compared well, falling along the $1: 1$ line with a mean error of -0.84 meters. Drawdown (hydraulic-head change) observations did not fit as well as other observations/prior-information (although the overall mean error was $-0.81 \mathrm{~m}$ ), most likely due to inadequately determined hydraulic properties and (or) pumping that was not adequately defined. The simulated hydraulic-head decline values were generally lower than observed, but matched the trends shown by the observations/prior-information. The threedimensional aspects of the flow system were simulated accurately, with downward hydraulic gradients in recharge areas and upward hydraulic gradients in discharge areas. Simulated values and observations/prior-information generally fell on the 1:1 line, indicating a good model fit. The root mean squared error (RMSE) was slightly better than that in DVRFS v. 1.0 for hydraulic-head and drawdown data, being reduced by more than 42 percent. Although simulated values of flow for each boundary segment (or subsegment) differed somewhat from those previously reported and used in DVRFS v. 1.0, except for one small part of the Pahranagat and Sheep Range segments, the direction of flow was simulated accurately and the flows generally matched well within their estimated error. The observations/prior-information for the boundary flows were matched better than in DVRFS v. 1.0., with the RMSE reduced by 87 percent. Model-computed discharges through the drains matched spring discharge and ET estimates fairly well, resulting in a RMSE reduction of 62 percent. The overall RMSE was reduced by 83 percent from DVRFS v. 1.0 to DVRFS v. 2.0. 
Most of the parameters estimated during model calibration were related to hydraulic conductivity (horizontal hydraulic conductivity, horizontal-flow barriers, drain conductances, vertical anisotropy, and depth decay of hydraulic conductivity). Pilot points were used to estimate horizontal hydraulic conductivity in Pahrump Valley and to better quantify storage properties for the transient simulation. Of the more than 500 parameters, most were estimated in the combined steadystate and transient simulation. At times during the calibration process many of the defined parameters were not estimated because they were relatively insensitive at that point of the calibration. In general, estimated parameter values were similar to those estimated in DVRFS v. 1.0. Compared to field-measured hydraulic-conductivity estimates, estimated parameter values of hydraulic conductivity were reasonable and provided a good model fit.

Selected areas within the model domain were examined to assess conformance of the simulated behavior with respect to the conceptual model of the DVRFS. These areas were at the Nevada National Security Site (Pahute Mesa, Yucca Flat, and the Eleana Range), Bare Mountain, the southern Funeral Range, southern Pahrump Valley, and Chicago Valley. Evaluation showed that, for the most part, DVRFS v. 2.0 accurately simulated the consensus conceptual model of groundwater flow in the DVRFS. The hydrogeology of the Resting Spring Range may need to be re-evaluated due to the possibility of low-permeability rocks in the range that could block interbasin flow into the Lower Amargosa Valley.

\section{References Cited}

Anderman, E.R., and Hill, M.C., 2000, MODFLOW-2000, The U.S. Geological Survey modular ground-water flow model-Documentation of the Hydrogeologic-Unit Flow (HUF) package: U.S. Geological Survey Open-File Report 2000-342, 89 p.

Anderman, E.R., and Hill, M.C., 2003, MODFLOW-2000, The U.S. Geological Survey modular ground-water flow model-Three additions to the Hydrogeologic-Unit Flow (HUF) package-Alternative storage for the uppermost active cells (STYP parameter type), flows in hydrogeologic units, and the hydraulic conductivity depth-dependence (KDEP) capability: U.S. Geological Survey Open-File Report 2003-347, 36 p.

Aster, R.C., Borchers, Brian, and Thurber, C.H., 2013, Parameter estimation and inverse problems, 2nd ed.: Oxford, Academic Press, 376 p.

Banta, E.R., and Provost, A.M., 2008, User guide for HUFPrint, a tabulation and visualization utility for the Hydrogeologic-Unit Flow (HUF) package of MODFLOW: U.S. Geological Survey Techniques and Methods 6-A27, 13 p.
Bechtel Nevada, 2002, A hydrostratigraphic model and alternatives for the groundwater flow and contaminant transport model of Corrective Action Units 101 and 102-Central and western Pahute Mesa, Nye County, Nevada: U.S. Department of Energy Report DOE/NV/11718-706, 383 p.

Bechtel Nevada, 2005, A hydrostratigraphic framework model and alternatives for the groundwater flow and contaminant transport model of Corrective Action Unit 98: Frenchman Flat, Clark, Lincoln, and Nye Counties, Nevada: U.S. Department of Energy Report DOE/NV/11718-1064, 240 p.

Bechtel Nevada, 2006, A hydrostratigraphic model and alternatives for the groundwater flow and contaminant transport model of Corrective Action Unit 97-Yucca Flat-Climax Mine, Lincoln and Nye Counties, Nevada: U.S. Department of Energy Report DOE/NV/11718-1119, 288 p.

Bechtel SAIC Company, 2002, Geologic framework model (GFM2000): Las Vegas, Nevada, U.S. Department of Energy Report MDL-NBS-GS-000002, REV 01, Accession No. MOL.20020530.0078.

Bedinger, M.S., and Harrill, J.R., 2010, Appendix 1. Regional potential for interbasin flow of groundwater, in Belcher, W.R., and Sweetkind, D.S., eds., Death Valley regional groundwater flow system, Nevada and California-Hydrogeologic framework and transient groundwater flow model: U.S. Geological Survey Professional Paper 1711, p. 347-364.

Bedinger, M.S., Langer, W.H., and Reed, J.E., 1989a, Groundwater hydrology, in Bedinger, M.S., Sargent, K.A., and Langer, W.H., eds., Studies of geology and hydrology in the Basin and Range Province, southwestern United States, for isolation of high-level radioactive waste - Characterization of the Death Valley region, Nevada and California: U.S. Geological Survey Professional Paper 1370-F, p. 28-35.

Bedinger, M.S., Langer, W.H., and Reed, J.E., 1989b, Hydraulic properties of rocks in the Basin and Range Province, in Bedinger, M.S., Sargent, K.A., Langer, W.H., Sherman, F.B., Reed, J.E., and Brady, B.T., eds., Studies of geology and hydrology in the Basin and Range Province, southwestern United States, for isolation of high-level radioactive waste-Basis of characterization and evaluation: U.S. Geological Survey Professional Paper 1370-A, p. 16-18.

Belcher, W.R., ed., 2004, Death Valley regional groundwater flow system, Nevada and California-Hydrogeologic framework and transient ground-water flow model: U.S. Geological Survey Scientific Investigations Report 2004-5205, 408 p.

Belcher, W.R., Bedinger, M.S., Back, J.T., and Sweetkind, D.S., 2009, Interbasin flow in the Great Basin with special reference to the southern Funeral Mountains and the source of Furnace Creek springs, Death Valley, California, U.S.: Journal of Hydrology, v. 369, p. 30-43. 
Belcher, W.R., D'Agnese, F.A., and O'Brien, G.M., 2010, Chapter A. Introduction, in Belcher, W.R., and Sweetkind, D.S., eds., Death Valley regional groundwater flow system, Nevada and California-Hydrogeologic framework and transient groundwater flow model: U.S. Geological Survey Professional Paper 1711, p. 3-17.

Belcher, W.R., Elliott, P.E., and Geldon, A.L., 2001, Hydraulic property estimates for use with a transient ground-water flow model of the Death Valley regional ground-water flow system, Nevada and California: U.S. Geological Survey Water-Resources Investigations Report 01-4210, 28 p.

Belcher, W.R., and Sweetkind, D.S., eds., 2010, Death Valley regional groundwater flow system, Nevada and CaliforniaHydrogeologic framework and transient groundwater flow model: U.S. Geological Survey Professional Paper 1711, $398 \mathrm{p}$.

Bennett, G.D., Reilly, T.E., and Hill, M.C., 1990, Technical training notes in groundwater hydrology-Radial flow to a well: U.S. Geological Survey Water-Resources Investigations Report 89-4134, 83 p.

Benson, Lyman, and Darrow, R.A., 1981, Trees and shrubs of the southwestern deserts: Tucson, University of Arizona Press, $416 \mathrm{p}$.

Bredehoeft, John, Fridrich, Christopher, and King, Michael, 2008, Groundwater flow through the Funeral Mountains, Death Valley National Park, California: International Waste Management Conference Proceedings, Las Vegas, NV, September 7-11, 2008.

Brooks, L.E., Masbruch, M.D., Sweetkind, D.S., and Buto, S.G., 2014, Steady-state numerical groundwater flow model of the Great Basin carbonate and alluvial aquifer system: U.S. Geological Survey Scientific Investigations Report 2014-5213, 124 p., 2 pl.

Burow, K.R., Shelton, J.L., Hevesi, J.A., and Weissmann, G.S., 2004, Hydrogeologic characterization of the Modesto area, San Joaquin Valley, California: U.S. Geological Survey Scientific Investigations Report 2004-5232, 54 p.

Carr, W.J., 1984, Regional structural setting of Yucca Mountain, southeastern Nevada, and late Cenozoic rates of tectonic activity in part of the southwestern Great Basin, Nevada and California: U.S. Geological Survey Open-File Report 84-854, $98 \mathrm{p}$.

Czarnecki, J.B., 1985, Simulated effects of increased recharge on the ground-water flow system of Yucca Mountain and vicinity, Nevada-California: U.S. Geological Survey WaterResources Investigations Report 84-4344, 33 p.

Czarnecki, J.B., and Waddell, R.K., 1984, Finite-element simulation of ground-water flow in the vicinity of Yucca Mountain, Nevada-California: U.S. Geological Survey Water-Resources Investigations Report 84-4349, 38 p.
D’Agnese, F.A., Faunt, C.C., and Turner, A.K., 1998, An estimated potentiometric surface of the Death Valley Region, Nevada and California, developed using geographic information system and automated interpolation techniques: U.S. Geological Survey Water-Resources Investigations Report 97-4052, 15 p., 1 pl.

D’Agnese, F.A., Faunt, C.C., Turner, A.K., and Hill, M.C., 1997, Hydrogeologic evaluation and numerical simulation of the Death Valley regional ground-water flow system, Nevada and California: U.S. Geological Survey WaterResources Investigations Report 96-4300, 124 p.

D’Agnese, F.A., O’Brien, G.M., Faunt, C.C., Belcher, W.R., and San Juan, Carma, 2002, A three-dimensional numerical model of predevelopment conditions in the Death Valley regional ground-water flow system, Nevada and California: U.S. Geological Survey Water-Resources Investigations Report 02-4102, 114 p.

Davis, J.C., 1986, Statistics and data analysis in geology, 2nd ed.: New York, John Wiley and Sons, 646 p.

Doherty, John, 2003, Groundwater model calibration using pilot points and regularization: Groundwater, v. 41, p. $170-177$.

Doherty, John, 2005, PEST-Model-independent parameter estimation and uncertainty analysis, user manual (5th ed.): Watermark Numerical Computing, $336 \mathrm{p}$.

Doherty, John, 2010, PEST-Model-independent parameter estimation and uncertainty analysis: Watermark Numerical Computing, Brisbane, Queensland, Australia, available at www.pesthomepage.org.

Doherty, J.E., Fienen, M.N., and Hunt, R.J., 2010, Approaches to highly parameterized inversion-Pilot-point theory, guidelines, and research directions: U.S. Geological Survey Scientific Investigations Report 2010-5168, 36 p.

Doherty, John, and Hunt, R.J., 2009, Two statistics for evaluating parameter identifiability and error reduction: Journal of Hydrology, v. 366, p. 119-127.

Doherty, J.E., and Hunt, R.J., 2010, Approaches to highly parameterized inversion - A guide to using PEST for groundwater-model calibration: U.S. Geological Survey Scientific Investigations Report 2010-5169, 59 p.

Domenico, P.A., and Schwartz, F.W., 1990, Physical and chemical hydrogeology: John Wiley and Sons, New York, $824 \mathrm{p}$.

Dudley, W.W., Jr., and Larson, J.D., 1976, Effect of irrigation pumping on desert pupfish habitats in Ash Meadows, Nye County, Nevada: U.S. Geological Survey Professional Paper 927, 52 p.

Eakin, T.E., Price, Don, and Harrill, J.D., 1976, Summary appraisals of the Nation's ground-water resources - Great Basin region: U.S. Geological Survey Professional Paper 813-G, $37 \mathrm{p}$. 
Evans, J.P., Forster, C.B., and Goddard, J.V., 1997, Permeability of fault-related rocks, and implications for hydraulic structure of fault zones: Journal of Structural Geology, v. 19 , p. 1393-1404.

Faunt, C.C., 1997, Effect of faulting on ground-water movement in the Death Valley region, Nevada and California: U.S. Geological Survey Water-Resources Investigations Report 95-4132, 42 p.

Faunt, C.C., ed., 2009, Groundwater availability of the Central Valley aquifer, California: U.S. Geological Survey Professional Paper 1766, $225 \mathrm{p}$.

Faunt, C.C., Belitz, Kenneth, and Hanson, R.H., 2010, Development of a three-dimensional model of sedimentary texture in valley-fill deposits of Central Valley, California, USA: Hydrogeology, v. 18, p. 625-649.

Faunt, C.C., Blainey, J.B., Hill, M.C., D'Agnese, F.A., and O’Brien, G.M., 2010, Chapter F. Transient flow model, in Belcher, W.R., and Sweetkind, D.S., eds., Death Valley regional groundwater flow system, Nevada and CaliforniaHydrogeologic framework and transient groundwater flow model: U.S. Geological Survey Professional Paper 1711, p. 251-344.

Faunt, C.C., D'Agnese, F.A., and O'Brien, G.M., 2010, Chapter D. Hydrology, in Belcher, W.R., and Sweetkind, D.S., eds., Death Valley regional groundwater flow system, Nevada and California-Hydrogeologic framework and transient groundwater flow model: U.S. Geological Survey Professional Paper 1711, p. 137-159.

Faunt, C.C., Provost, A.M., Hill, M.C., and Belcher, W.R., 2011, Comment on "An unconfined groundwater model of the Death Valley Regional System and a comparison to its confined predecessor" by R.W.H. Carroll, G.M. Pohll, and R.L. Hershey: Journal of Hydrology v. 397, no. 3-4, p. 306-309.

Faunt, C.C., Sweetkind, D.S., and Belcher, W.R., 2010, Chapter E. Hydrogeologic framework model, in Belcher, W.R., and Sweetkind, D.S., eds., Death Valley regional groundwater flow system, Nevada and California-Hydrogeologic framework and transient ground-water flow model: U.S. Geological Survey Professional Paper 1711, p. 161-250.

Fenelon, J.M., Sweetkind, D.S., Elliott, P.E., and Laczniak, R.J., 2012, Conceptualization of the predevelopment groundwater flow system and transient water-level responses in Yucca Flat, Nevada National Security Site, Nevada: U.S. Geological Survey Scientific Investigations Report 2012-5196, 61 p.

Fenelon, J.M., Sweetkind, D.S., and Laczniak, R.J., 2010, Groundwater flow systems at the Nevada Test Site, Nevada-A synthesis of potentiometric contours, hydrostratigraphy, and geologic structures: U.S. Geological Survey Professional Paper 1771, 54 p., 6 pl.
Fenneman, N.M., 1931, Physiography of western United States: New York, McGraw-Hill Book Company, Inc., $534 \mathrm{p}$.

Freeze, R.A., and Cherry, J.A., 1979, Ground water: Englewood Cliffs, N.J., Prentice-Hall, Inc., 604 p.

Fridrich, C.J., Dudley, W.W., Jr., and Stuckless, J.S., 1994, Hydrogeologic analysis of the saturated-zone ground-water system under Yucca Mountain, Nevada: Journal of Hydrology, v. 154, p.133-168.

Fridrich, C.J., Thompson, R.A., Slate, J.L., Berry, M.E., and Machette, M.N., 2012, Geologic map of the southern Funeral Mountains including nearby groundwater discharge sites in Death Valley National Park, California and Nevada: U.S. Geological Survey Scientific Investigations Map 3151, 20 p., pamphlet, 1 sheet, scale 1:50,000.

Grose, T.L., and Smith, G.I., 1989, Geology, in Bedinger, M.S., Sargent, K.A., and Langer, W.H., eds., Studies of geology and hydrology in the Basin and Range Province, southwestern United States, for isolation of high-level radioactive waste: U.S. Geological Survey Professional Paper 1370-F, p. 5-19.

Halford, K.J., and Hanson, R.T., 2002, User guide for the drawdown-limited, Multi-Node Well (MNW) package for the U.S. Geological Survey's modular three-dimensional finite-difference groundwater flow model, versions MODFLOW-96 and MODFLOW-2000: U.S. Geological Survey Open-File Report 02-293, 33 p.

Harbaugh, A.W., 2005, MODFLOW-2005, The U.S. Geological Survey modular ground-water model-The groundwater flow process: U.S. Geological Survey Techniques and Methods 6-A16, variously paginated.

Harbaugh, A.W., Banta, E.R., Hill, M.C., and McDonald, M.G., 2000, MODFLOW-2000, the U.S. Geological Survey modular ground-water model - User guide to modularization concepts and the ground-water flow process: U.S. Geological Survey Open-File Report 00-92, 121 p.

Harrill, J.R., and Bedinger, M.S., 2010, Appendix 2. Estimated boundary flows, in Belcher, W.R., and Sweetkind, D.S., eds., Death Valley regional groundwater flow system, Nevada and California-Hydrogeologic framework and transient groundwater flow model: U.S. Geological Survey Professional Paper 1711, p. 365-398.

Harrill, J.R., Gates, J.S., and Thomas, J.M., 1988, Major ground-water flow systems in the Great Basin region of Nevada, Utah, and adjacent states: U.S. Geological Survey Hydrologic Investigations Atlas HA-694-C, scale 1:1,000,000, 2 sheets.

Harrill, J.R., and Prudic, D.E., 1998, Aquifer systems in the Great Basin region of Nevada, Utah, and adjacent states-A summary report: U.S. Geological Survey Professional Paper 1409-A, 66 p. 
Heilweil, V.M., and Brooks, L.E, 2011, Potentiometric surface map and likelihood of hydraulic connections across hydrographic area boundaries of the Great Basin carbonate and alluvial aquifer system study area, in Heilweil, V.M., and Brooks, L.E., eds., 2011, Conceptual model of the Great Basin carbonate and alluvial aquifer system: U.S. Geological Survey Scientific Investigations Report 2010-5193, $191 \mathrm{p}$.

Hevesi, J.A., Flint, A.L., and Flint, L.E., 2003, Simulation of net infiltration and potential recharge using a distributed parameter watershed model of the Death Valley region, Nevada and California: U.S. Geological Survey WaterResources Investigations Report 2003-4090, 161 p.

Hill, M.C., 1990, Preconditioned conjugate-gradient 2 (PCG2), a computer program for solving ground-water flow equations: U.S. Geological Survey Water-Resources Investigations Report 90-4048, 43 p.

Hill, M.C., Banta, E.R., Harbaugh, A.W., and Anderman, E.R., 2000, MODFLOW-2000, The U.S. Geological Survey's modular ground-water flow model - User guide to the observation, sensitivity, and parameter-estimation procedures and three post-processing programs: U.S. Geological Survey Open-File Report 00-184, 209 p.

Hill, M.C., and Østerby, O., 2003, Determining extreme parameterization correlation in ground water models: Ground Water v. 41, no. 4, p. 420-430.

Hill, M.C., and Tiedeman, C.R, 2003, Weighting observations in the context of calibrating ground-water models, in Kovar, Karel, and Zbynek, Hrkal, eds., Calibration and reliability in groundwater modeling, a few steps closer to reality: International Association of Hydrological Sciences Publication 277, p. 196-203.

Hill, M.C., and Tiedeman, C.R., 2007, Effective groundwater model calibration - With analysis of data, sensitivities, predictions, and uncertainty: New York, Wiley and Sons, 464 p.

Hsieh, P.A., and Freckleton, J.R., 1993, Documentation of a computer program to simulate horizontal-flow barriers using the U.S. Geological Survey modular three-dimensional finite difference ground-water flow model: U.S. Geological Survey Open-File Report 92-477, 32 p.

Inyo County Yucca Mountain Repository Assessment Office, 2007, Inyo County final project report from 2002-2005: Death Valley lower carbonate aquifer monitoring program -Wells down gradient of the proposed Yucca Mountain nuclear waste repository: U.S. Department of Energy Cooperative Agreement DE-FC08-02RW12162 Final Project Report, 39 p., Nuclear Regulatory Commission Accession Number ML081070545, http://pbadupws.nrc.gov/docs/ ML0810/ML081070525.html.
IT Corporation, 1996a, Underground test area subproject, Phase I, Data analysis task, volume VI-Groundwater flow model data documentation package: Las Vegas, Nev., Report ITLV/10972-181, prepared for the U.S. Department of Energy, 8 volumes, variously paginated.

IT Corporation, 1996b Underground test area subproject, Phase I, Data analysis task, volume I-Geologic model data documentation package: Las Vegas, Nev., Report ITLV/10972-181, prepared for the U.S. Department of Energy, 8 volumes, variously paginated.

IT Corporation, 1996c, Underground test area subproject, Phase I, Data analysis task, volume II-Potentiometric data documentation package: Las Vegas, Nev., Report ITLV/10972-181, prepared for the U.S. Department of Energy, 8 volumes, variously paginated.

Laczniak, R.J., Cole, J.C., Sawyer, D.A., and Trudeau, D.A., 1996, Summary of hydrogeologic controls on ground-water flow at the Nevada Test Site, Nye County, Nevada: U.S. Geological Survey Water-Resources Investigations Report 96-4109, 59 p.

McKee, E.H., Phelps, G.A., and Mankinen, E.A., 2001, The Silent Canyon caldera - A three-dimensional model as part of a Pahute Mesa-Oasis Valley, Nevada, hydrogeologic model: U.S. Geological Survey Open-File Report 2001-297, $13 \mathrm{p}$.

McKee, E.H., Wickham, T.A., and Wheeler, K.L., 1998, Evaluation of faults and their effect on ground-water flow southwest of Frenchman Flat, Nye and Clark Counties, Nevada - A digital database: U.S. Geological Survey OpenFile Report 98-580, 16 p., 4 pl.

Mehl, S.W., and Hill, M.C., 2005, MODFLOW-2005, The U.S. Geological Survey modular groundwater model-Documentation of shared node local grid refinement (LGR) and the Boundary Flow and Head (BFH) package: U.S. Geological Survey Techniques and Methods 6-A12, $68 \mathrm{p}$.

Moore, Catherine, and Doherty, John, 2006, The cost of uniqueness in groundwater model calibration: Advances in Water Resources, v. 29, no. 4, p. 605-623.

Moreo, M.T., Halford, K.J., La Camera, R.J., and Laczniak, R.J., 2003, Estimated groundwater withdrawals from the Death Valley regional flow system, Nevada and California, 1913-98: U.S. Geological Survey Water-Resources Investigations Report 03-4245, 28 p.

Moreo, M.T., and Justet, Leigh, 2008, Update to the groundwater withdrawals database for the Death Valley regional groundwater flow system, Nevada and California, 19132003: U.S. Geological Survey Data Series 340, 10 p. 
National Security Technologies, LLC, 2007, A hydrostratigraphic model and alternatives for the groundwater flow and contaminant transport model of Corrective Action Unit 99-Rainier Mesa-Shoshone Mountain, Nye County, Nevada: U.S. Department of Energy Report DOE/ NV/25946-146, $302 \mathrm{p}$.

Nevada Division of Water Resources, 1972, Water resources and inter-basin flow, in Nevada Division of Water Resources, Water for Nevada: Hydrologic Atlas Map S-13, scale 1:750,000.

Oatfield, W.J., and Czarnecki, J.B., 1989, Hydrogeologic inferences from drillers' logs and from gravity and resistivity surveys in the Amargosa Desert, southern Nevada: U.S. Geological Survey Open-File Report 89-234, 29 p.

Oatfield, W.J., and Czarnecki, J.B., 1991, Hydrogeologic inferences from drillers' logs and from gravity and resistivity surveys in the Amargosa Desert, southern Nevada: Journal of Hydrology, v. 124, p. 131-158.

Pavelko, M.T., 2010, Water-level database update for the Death Valley regional groundwater flow system, Nevada and California, 1907-2007: U.S. Geological Survey Data Series Report 519, 14 p.

Phillips, S.P., and Belitz, Kenneth, 1991, Calibration of a textured-based model of a ground-water flow system, western San Joaquin Valley, California: Ground Water, v. 29, p. 702-715.

Poeter, E.P., Hill, M.C., Banta, E.R., Mehl, Steffen, and Christensen, Steen, 2005, UCODE_2005 and six other computer codes for universal sensitivity analysis, calibration, and uncertainty evaluation: U.S. Geological Survey Techniques and Methods 6-A11, $283 \mathrm{p}$.

Pohlmann, Karl, and Ye, Min, 2012, Numerical simulation of inter-basin groundwater flow into northern Yucca Flat, Nevada National Security Site, using the Death Valley regional flow system model: DOE/NV/26383-18, publication number $45235,79 \mathrm{p}$.

Potter, C.J., Sweetkind, D.S., Dickerson, R.P., and Killgore, M.L., 2002, Hydrostructural maps of the Death Valley regional flow system, Nevada and California: U.S. Geological Survey Miscellaneous Field Studies Map MF-2372, 12 p., 2 sheets, 1:250,000 scale.

PRISM, 2008, Precipitation data from PRISM Group at Oregon State University, accessed October 3, 2008, at http://www.prism.oregonstate.edu/.

Prothro, L.B., Drellack, S.L., Jr., and Mercadante, J.M., 2009, A hydrostratigraphic system for modeling groundwater flow and radionuclide migration at the Corrective Action Unit scale, Nevada Test Site and surrounding areas, Clark, Lincoln, and Nye Counties, Nevada: U.S. Department of Energy Report DOE/NV/25946-630, 145 p.
Prudic, D.E., Harrill, J.R., and Burbey, T.J., 1995, Conceptual evaluation of regional ground-water flow in the carbonaterock province of the Great Basin, Nevada, Utah, and adjacent states: U.S. Geological Survey Professional Paper 1409-D, 102 p.

Rawling, G.C., Goodwin, L.B., and Wilson, J.L., 2001, Internal architecture, permeability structure, and hydrologic significance of contrasting fault-zone types: Geology, v. 29, p. 43-46.

Reilly, T.E., and Harbaugh, A.W., 2004, Guidelines for evaluating ground-water flow models: U.S. Geological Survey Scientific Investigations Report 2004-5038, 30 p.

Rice, W.A., 1984, Preliminary two-dimensional regional hydrologic model of the Nevada Test Site and vicinity: Albuquerque, N. Mex., Sandia National Laboratories Report SAND83-7466, $89 \mathrm{p}$.

San Juan, C.A., Belcher, W.R., Laczniak, R.J., and Putnam, H.M., 2010, Hydrologic components for model development, in Belcher, W.R., and Sweetkind, D.S., eds., Death Valley regional groundwater flow system, Nevada and California-Hydrogeologic framework and transient groundwater flow model: U.S. Geological Survey Professional Paper 1711, p. 95-132.

Scott, B.R., Smales, T.J., Rush, F.E., and Van Denburgh, A.S., 1971, Nevada's water resources: Nevada Division of Water Resources, Water for Nevada Report 3, $87 \mathrm{p}$.

Sheets, R.A., Hill, M.C., Haitjema, H.M., Provost, A.M., and Masterson, J.P., 2014, Simulation of water-table aquifers using specified saturated thickness: Groundwater, v. 53, no. 1, p. 151-157.

Sinton, P.O., 1987, Three-dimensional, steady-state, finite-difference model of the ground-water flow system in the Death Valley ground-water basin, Nevada-California: Golden, Colorado School of Mines, unpublished Master's thesis, $145 \mathrm{p}$.

Slate, J.L, Berry, M.E., Rowley, P.D., Fridrich, C.J., Morgan, K.S., Workman, J.B., Young, O.D., Dixon, G.L., Williams, V.S., McKee, E.H., Ponce, D.A., Hildenbrand, T.G., Swadley, W.C., Lundstrom, S.C., Ekren, E.B., Warren, R.G., Cole, J.C., Fleck, R.J., Lanphere, M.A., Sawyer, D.A., Minor, S.A., Grunwald, D.J., Laczniak, R.J., Menges, C.M., Yount, J.C., and Jayko, A.S., 2000, Digital geologic map of the Nevada Test Site and vicinity, Nye, Lincoln, and Clark Counties, Nevada, and Inyo County, California: U.S. Geological Survey Open-File Report 99-554-A, 53 p., scale 1:120,000.

Steinkampf, W.C., and Werrell, W.E., 2001, Ground-water flow to Death Valley as inferred from the chemistry and geohydrology of selected springs in Death Valley National Park, California and Nevada: U.S. Geological Survey Water-Resources Investigations Report 98-4114, 37 p. 
Stonestrom, D.A., Prudic, D.E., Laczniak, R.J., Akstin, K.C., Boyd, R.A., and Henkelman, K.K., 2003, Estimates of deep percolation beneath native vegetation, irrigated fields, and the Amargosa-River channel, Amargosa Desert, Nye County, Nevada: U.S. Geological Survey Open-File Report 03-104, $83 \mathrm{p}$.

Stuckless, J.S., and O'Leary, D., 2007, Geology of the Yucca Mountain region, in Stuckless, J.S., and Levitch, R.A., eds., The geology and climatology of Yucca Mountain and vicinity, southern Nevada and California: Geological Society of America Memoir 199, p. 9-52.

Sweetkind, D.S., Belcher, W.R., Faunt, C.C., and Potter, C.J., 2010, Chapter B. Geology and hydrology, in Belcher, W.R., and Sweetkind, D.S., eds., Death Valley regional groundwater flow system, Nevada and California-Hydrogeologic framework and transient groundwater flow model: U.S. Geological Survey Professional Paper 1711, p. 19-94.

Sweetkind, D.S., Dickerson, R.P., Blakely, R., and Denning, P.D., 2001, Interpretive geologic cross sections for the Death Valley regional flow system and surrounding areas, Nevada and California: U.S. Geological Survey Miscellaneous Field Studies Map MF-2370, 3 pl., 32 p.

Sweetkind, D.S., Faunt, C.C., and Hanson, R.T., 2013, Construction of 3-D geologic framework and textural models for Cuyama Valley groundwater basin, California: U.S. Geological Survey Scientific Investigations Report 2013$5127,46 \mathrm{p}$.

Sweetkind, D.S., Fridrich, C.J., and Taylor, Emily, 2001, Facies analysis of Tertiary basin-filling rocks of the Death Valley regional ground-water system and surrounding areas, Nevada and California: U.S. Geological Survey Open-File Report 01-400, $55 \mathrm{p}$.

Sweetkind, D.S., Masbruch, M.D., Heilweil, V.M., and Buto, S.G., 2011, Chapter C. Groundwater flow, in Heilweil, V.M., and Brooks, L.E., eds., 2011, Conceptual model of the Great Basin carbonate and alluvial aquifer system: U.S. Geological Survey Scientific Investigations Report 20105193, $191 \mathrm{p}$.

Taylor, E.M., and Sweetkind, D.S., 2014, Three-dimensional geologic mapping of the Cenozoic basin fill, Amargosa Desert basin, Nevada and California: U.S. Geological Survey Scientific Investigations Report 2014-5003, 40 p., 2 appendixes.

Thomasson, H.J., Olmstead, F.H., and LeRoux, E.R., 1960, Geology, water resources, and usable ground-water storage capacity of part of Solano County, Calif.: U.S. Geological Survey Water-Supply Paper 1464, 693 p.

Tikhonov, A.N., and Arsenin, V.Y., 1977, Solution of ill-posed problems: Washington, D.C., Winston \& Sons, 272 p.
Tonkin, M.J., and Doherty, John, 2005, A hybrid regularized inversion methodology for highly parameterized environmental models: Water Resources Research, v. 41, W10412, 16 p., doi: 10.1029/2005WR003995

Waddell, R.K., 1982, Two-dimensional, steady-state model of ground-water flow, Nevada Test Site and vicinity, NevadaCalifornia: U.S. Geological Survey Water-Resources Investigations Report 84-4267, 72 p.

Winograd, I.J., Fridrich, C.J., Sweetkind, D., Belcher, W.R., and Thomas, J.M., 2005, Comment on "Testing the interbasin flow hypothesis at Death Valley, California": EOS, v. 86, no. 32, August 9, 2005, p. 295-296.

Winograd, I.J., and Pearson, F.J., Jr., 1976, Major carbon-14 anomaly in a regional carbonate aquifer-Possible evidence for megascale channeling, south-central Great Basin: Water Resources Research, v. 12, no. 6, p. 1125-1143.

Winograd, I.J., and Thordarson, William, 1975, Hydrogeologic and hydrochemical framework, south-central Great Basin, Nevada-California, with special reference to the Nevada Test Site: U.S. Geological Survey Professional Paper 712-C, $126 \mathrm{p}$.

Wood, D.B., 2009, Digitally available interval-specific rocksample data compiled from historical records, Nevada Test Site and vicinity, Nye County, Nevada (ver. 2.0): U.S. Geological Survey Data Series 297, 56 p., 6 digital appendixes.

Workman, J.B., Menges, C.M., Page, W.R., Taylor, E.M., Ekren, E.B., Rowley, P.D., Dixon, G.L., Thompson, R.A., and Wright, L.A., 2002, Geologic map of the Death Valley ground-water model area, Nevada and California: U.S. Geological Survey Miscellaneous Field Studies Map MF2381-A, scale 1:250,000, $26 \mathrm{p}$.

Yeh, W.W, 1986, Review of parameter identification procedures in groundwater hydrology-The inverse problem: Water Resources Research, v. 22, no. 2, p. 95-108. 


\section{Appendix 1. Simulated parameter values and pilot points estimated in DVRFS v. 2.0}

Table A-1. Simulated parameter values estimated in the Death Valley regional groundwater flow system (DVRFS) v. 2.0 model.

[Parameter values and sensitivities displayed in scientific notation format. drn_grp, drain conductance, in square meters per day $\left(\mathrm{m}^{2} / \mathrm{d}\right)$; flt_grp, fault hydraulic characteristic of barrier, in 1/d; hk_grp, hydraulic conductivity, in m/d; kdep, depth decay, in 1/m; stor_grp, storage, unitless; sy_grp, specific yield, unitless; NA, value not assigned]

\begin{tabular}{|c|c|c|c|c|c|}
\hline Group & Name & DVRFS v. 1.0 name if changed & DVRFS v. 1.0 value & DVRFS v. 2.0 value & DVRFS v. 2.0 sensitivity \\
\hline drn_grp & deep_drn & & $4.56 \mathrm{E}+01$ & 94.8958 & 0.168298 \\
\hline drn_grp & frncr_drn & & $1.00 \mathrm{E}+04$ & 134.369 & $6.57 \mathrm{E}-02$ \\
\hline drn_grp & up_dv_drn & & $1.00 \mathrm{E}+04$ & 568.765 & $1.03 \mathrm{E}-02$ \\
\hline drn_grp & up_dvn_drn & & $5.28 \mathrm{E}+01$ & $5.00 \mathrm{E}+00$ & 0.427278 \\
\hline drn_grp & up_pah_drn & & $1.95 \mathrm{E}+02$ & 796.385 & $2.21 \mathrm{E}-02$ \\
\hline drn_grp & up_ply_drn & & $8.39 \mathrm{E}+01$ & 47.822 & $2.18 \mathrm{E}-02$ \\
\hline drn_grp & upper_drn & & $1.08 \mathrm{E}+02$ & 10.631 & $2.42 \mathrm{E}-02$ \\
\hline flt_grp & b_alamandr & & $1.00 \mathrm{E}+00$ & 1.40678 & 7.19E-05 \\
\hline flt_grp & b_amargosa & & $1.00 \mathrm{E}+00$ & 1.09625 & 4.01E-05 \\
\hline flt_grp & b_ashmeado & & $1.00 \mathrm{E}+00$ & 0.877796 & $8.83 \mathrm{E}-05$ \\
\hline flt_grp & b_baremt_d & & $1.00 \mathrm{E}+00$ & $1.02 \mathrm{E}-04$ & $2.06 \mathrm{E}-04$ \\
\hline flt_grp & b_baremt_f & & $1.00 \mathrm{E}+00$ & $1.28 \mathrm{E}-05$ & $7.90 \mathrm{E}-03$ \\
\hline flt_grp & b_baremt_t & & $1.00 \mathrm{E}+00$ & 0.562924 & $3.65 \mathrm{E}-05$ \\
\hline flt_grp & b_beltedrn & & $1.00 \mathrm{E}+00$ & $1.00 \mathrm{E}-07$ & 4.18E-05 \\
\hline flt_grp & b_boundary & NA & NA & 2.8514 & $1.17 \mathrm{E}-04$ \\
\hline flt_grp & b_box_car & & $1.00 \mathrm{E}+00$ & 0.243362 & $6.57 \mathrm{E}-05$ \\
\hline flt_grp & b_cane_spr & NA & NA & $1.00 \mathrm{E}-07$ & $4.18 \mathrm{E}-0$ \\
\hline flt_grp & b_carpet_b & & $1.00 \mathrm{E}+00$ & $1.00 \mathrm{E}-07$ & $3.90 \mathrm{E}-03$ \\
\hline flt_grp & b_craterfl & & $1.00 \mathrm{E}+00$ & 2.2115 & $3.03 \mathrm{E}-05$ \\
\hline flt_grp & b_dv_kw & & $1.00 \mathrm{E}+00$ & $7.00 \mathrm{E}-06$ & $7.11 \mathrm{E}-04$ \\
\hline flt_grp & b_dv_n & & $2.40 \mathrm{E}-07$ & 4.00E-06 & $3.51 \mathrm{E}-03$ \\
\hline flt_grp & b_dv_n2 & & $1.00 \mathrm{E}+00$ & $3.82 \mathrm{E}-06$ & 4.99E-04 \\
\hline flt_grp & b_dv_sarat & & $1.00 \mathrm{E}+00$ & 4.10E-03 & 4.83E-05 \\
\hline flt_grp & b_dvfc_fcr & & $1.00 \mathrm{E}-07$ & $1.76 \mathrm{E}-05$ & $2.75 \mathrm{E}-03$ \\
\hline flt_grp & b_dvfcfz_c & & $1.00 \mathrm{E}+00$ & $1.82 \mathrm{E}-05$ & $5.12 \mathrm{E}-03$ \\
\hline flt_grp & b_dvfcfz_s & & $1.00 \mathrm{E}+00$ & $6.77 \mathrm{E}-05$ & 4.64E-04 \\
\hline flt_grp & b_eagle_mt & & $1.00 \mathrm{E}+00$ & $8.28 \mathrm{E}-02$ & $3.37 \mathrm{E}-05$ \\
\hline flt_grp & b_fcfz & & $1.00 \mathrm{E}+00$ & $9.13 \mathrm{E}-03$ & $1.28 \mathrm{E}-04$ \\
\hline flt_grp & b_grandvie & & $1.00 \mathrm{E}+00$ & $1.00 \mathrm{E}-07$ & $8.22 \mathrm{E}-04$ \\
\hline flt_grp & b_grav_n & & $1.00 \mathrm{E}+00$ & 1.02258 & $1.25 \mathrm{E}-04$ \\
\hline flt_grp & b_grav_s & & $1.00 \mathrm{E}+00$ & $2.57 \mathrm{E}-05$ & $1.48 \mathrm{E}-02$ \\
\hline flt_grp & b_hogback & & $1.00 \mathrm{E}+00$ & $8.66 \mathrm{E}-02$ & $1.54 \mathrm{E}-04$ \\
\hline flt_grp & b_hwy95 & & $2.95 \mathrm{E}-04$ & $1.80 \mathrm{E}-05$ & $1.40 \mathrm{E}-02$ \\
\hline flt_grp & b_lvvsz_1 & & $9.00 \mathrm{E}-04$ & $6.16 \mathrm{E}-06$ & $1.98 \mathrm{E}-03$ \\
\hline flt_grp & b_lvvsz_i2 & & 4.19E-08 & $6.00 \mathrm{E}-07$ & $5.97 \mathrm{E}-03$ \\
\hline flt_grp & b_lvvsz_is & & $1.10 \mathrm{E}-08$ & $5.83 \mathrm{E}-02$ & 4.65E-05 \\
\hline flt_grp & b_lvvsz_iw & & $9.00 \mathrm{E}-04$ & 3.67E-04 & $1.91 \mathrm{E}-03$ \\
\hline flt_grp & b_pahrump & & $5.52 \mathrm{E}-07$ & $5.57 \mathrm{E}-05$ & $3.77 \mathrm{E}-03$ \\
\hline flt_grp & b_paintbrc & & $1.00 \mathrm{E}+00$ & 1.8266 & $6.70 \mathrm{E}-05$ \\
\hline flt_grp & b_rock_val & NA & NA & 7.77E-03 & $2.36 \mathrm{E}-04$ \\
\hline flt_grp & b_sheephea & & $1.00 \mathrm{E}+00$ & $3.16 \mathrm{E}-05$ & $3.05 \mathrm{E}-03$ \\
\hline flt_grp & b_solitari & & $4.45 \mathrm{E}-05$ & $1.00 \mathrm{E}-07$ & $1.46 \mathrm{E}-03$ \\
\hline flt_grp & b_stewart & & $1.00 \mathrm{E}+00$ & $2.11 \mathrm{E}-03$ & $1.82 \mathrm{E}-04$ \\
\hline
\end{tabular}


Table A-1. Simulated parameter values estimated in the Death Valley regional groundwater flow system (DVRFS) v. 2.0 model.—Continued [Parameter values and sensitivities displayed in scientific notation format. drn_grp, drain conductance, in square meters per day ( $\mathrm{m}^{2} / \mathrm{d}$ ); flt_grp, fault hydraulic characteristic of barrier, in 1/d; hk_grp, hydraulic conductivity, in m/d; kdep, depth decay, in 1/m; stor_grp, storage, unitless; sy_grp, specific yield, unitless; NA, value not assigned]

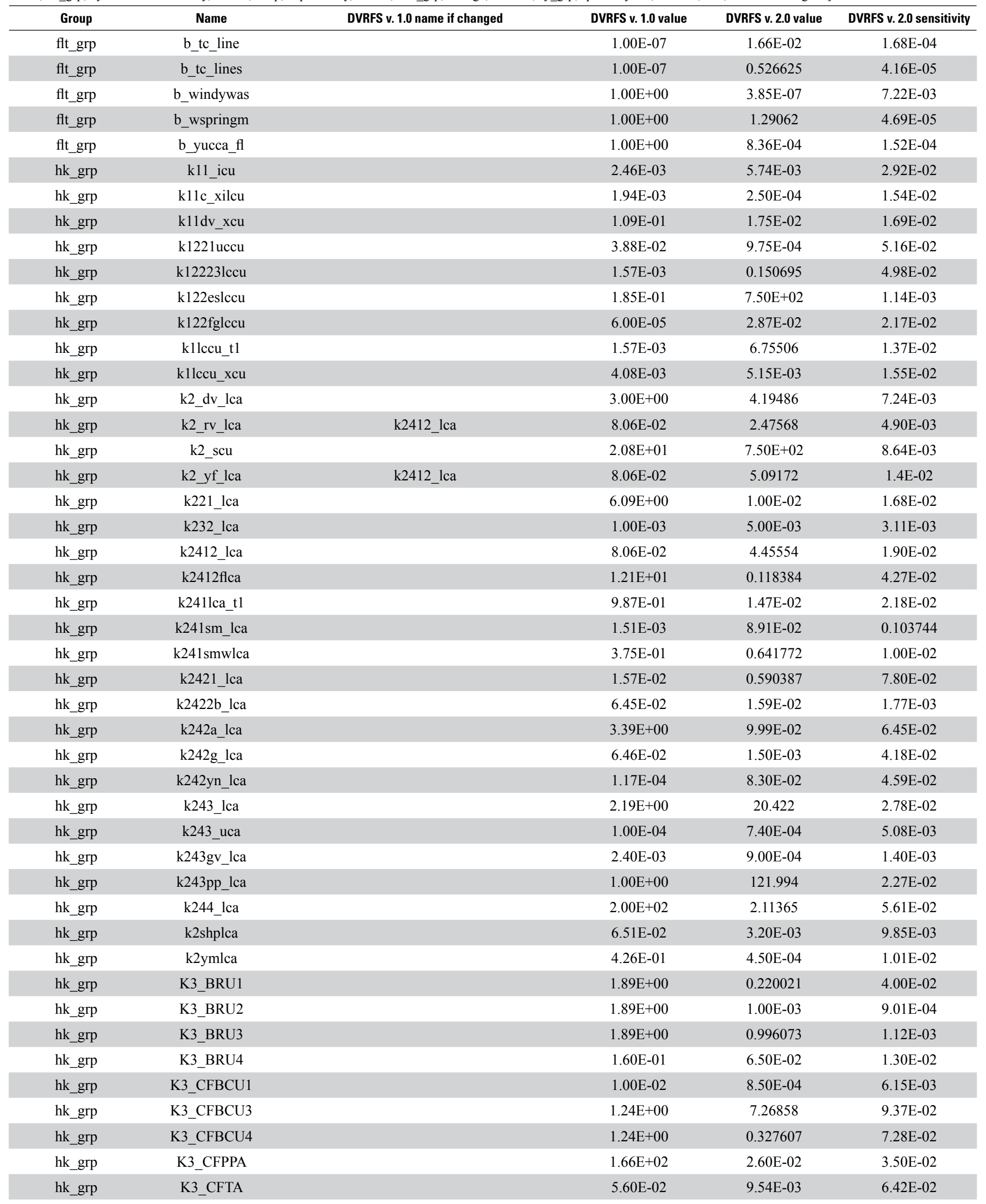


Table A-1. Simulated parameter values estimated in the Death Valley regional groundwater flow system (DVRFS) v. 2.0 model.-Continued

[Parameter values and sensitivities displayed in scientific notation format. drn_grp, drain conductance, in square meters per day ( $\mathrm{m}^{2} / \mathrm{d}$ ); flt_grp, fault hydraulic characteristic of barrier, in 1/d; hk_grp, hydraulic conductivity, in m/d; kdep, depth decay, in 1/m; stor_grp, storage, unitless; sy_grp, specific yield, unitless; NA, value not assigned]

\begin{tabular}{|c|c|c|c|c|c|}
\hline Group & Name & DVRFS v. 1.0 name if changed & DVRFS v. 1.0 value & DVRFS v. 2.0 value & DVRFS v. 2.0 sensitivity \\
\hline hk_grp & K3_CHVU1 & & $1.60 \mathrm{E}-01$ & 8.99E-04 & $7.16 \mathrm{E}-03$ \\
\hline hk_grp & K3_CHVU2 & & $1.33 \mathrm{E}-01$ & $8.50 \mathrm{E}-04$ & $7.50 \mathrm{E}-03$ \\
\hline hk_grp & K3_CHVU4 & & $1.33 \mathrm{E}-01$ & $8.50 \mathrm{E}-04$ & $1.74 \mathrm{E}-03$ \\
\hline hk_grp & K3_LFU & & $1.33 \mathrm{E}-01$ & 1.89983 & $4.56 \mathrm{E}-02$ \\
\hline hk_grp & K3_TMVA3 & & $8.44 \mathrm{E}+00$ & 78.4122 & $9.05 \mathrm{E}-04$ \\
\hline hk_grp & K3_TMVA4 & & $8.44 \mathrm{E}+00$ & $9.15 \mathrm{E}-04$ & $7.88 \mathrm{E}-03$ \\
\hline hk_grp & K3_WVU & & $1.24 \mathrm{E}+00$ & 26.7827 & $2.99 \mathrm{E}-03$ \\
\hline hk_grp & k33_ovu & & $9.90 \mathrm{E}-03$ & 60.2019 & $1.93 \mathrm{E}-02$ \\
\hline hk_grp & K3PVA & & $2.89 \mathrm{E}+02$ & 90.6898 & $2.29 \mathrm{E}-02$ \\
\hline hk_grp & K3PVAtm & & $2.89 \mathrm{E}+02$ & 6.57622 & 4.26E-02 \\
\hline hk_grp & k4_vf_aq & & 5.97E-01 & 11.4294 & $2.26 \mathrm{E}-02$ \\
\hline hk_grp & k4_vf_cu & & $1.58 \mathrm{E}+00$ & 0.692728 & $1.05 \mathrm{E}-02$ \\
\hline hk_grp & k4_vf_oaa & & 5.92E-02 & $4.50 \mathrm{E}-02$ & 2.97E-03 \\
\hline hk_grp & k42222_vsu & & $5.00 \mathrm{E}-03$ & $6.50 \mathrm{E}-02$ & $3.03 \mathrm{E}-02$ \\
\hline hk_grp & k4222p_vsu & $\begin{array}{l}\text { Pilot points added in DVRFS v. } 2.0 \text { for this } \\
\text { DVRFS v. } 1.0 \text { parameter (see below) }\end{array}$ & $5.81 \mathrm{E}-01$ & $1.00 \mathrm{E}+00$ & NA \\
\hline hk_grp & k4222s_vsu & & $1.26 \mathrm{E}-01$ & $2.22 \mathrm{E}-01$ & 8.63E-02 \\
\hline hk_grp & k422dv_vsu & & $8.80 \mathrm{E}-03$ & $3.50 \mathrm{E}-03$ & $8.11 \mathrm{E}-03$ \\
\hline hk_grp & ksamm1 & k4_vf_aq, k4_vf_cu, k4_vf_oaa, k3LFU_am & NA & $6.19 \mathrm{E}-02$ & $2.30 \mathrm{E}-03$ \\
\hline hk_grp & ksamm2 & k4_vf_aq, k4_vf_cu, k4_vf_oaa, k3LFU_am & NA & $5.82 \mathrm{E}-02$ & $1.65 \mathrm{E}-03$ \\
\hline hk_grp & ksamm3 & k4_vf_aq, k4_vf_cu, k4_vf_oaa, k3LFU_am & NA & 0.15662 & $2.31 \mathrm{E}-03$ \\
\hline hk_grp & ksamm4 & k4_vf_aq, k4_vf_cu, k4_vf_oaa, k3LFU_am & NA & 750 & $7.82 \mathrm{E}-03$ \\
\hline hk_grp & ksamm5 & k4_vf_aq, k4_vf_cu, k4_vf_oaa, k3LFU_am & NA & $8.00 \mathrm{E}-04$ & $2.42 \mathrm{E}-03$ \\
\hline hk_grp & ksamm6 & k4_vf_aq, k4_vf_cu, k4_vf_oaa, k3LFU_am & NA & $3.54 \mathrm{E}-02$ & $3.05 \mathrm{E}-03$ \\
\hline hk_grp & ksamm7 & k4_vf_aq, k4_vf_cu, k4_vf_oaa, k3LFU_am & NA & 3.10853 & $9.26 \mathrm{E}-02$ \\
\hline ir_grp & irr_delay & NA & $7.00 \mathrm{E}+00$ & $8.14 \mathrm{E}-01$ & $1.93 \mathrm{E}-14$ \\
\hline ir_grp & irr_return & NA & $2.50 \mathrm{E}+01$ & 0.3 & $2.96 \mathrm{E}-02$ \\
\hline kdep_grp & kdep_lcat & kdep_lcat1 & $1.50 \mathrm{E}-03$ & $9.37 \mathrm{E}-05$ & $2.45 \mathrm{E}-02$ \\
\hline kdep_grp & kdep_lccu & kdep_xl & $1.50 \mathrm{E}-03$ & $3.30 \mathrm{E}-03$ & 0.122993 \\
\hline kdep_grp & kdep_samm & kdep_vfvl & $1.20 \mathrm{E}-04$ & 4.59E-03 & 1.10329 \\
\hline kdep_grp & kdep_sm & kdep_lca & $1.00 \mathrm{E}-04$ & $1.91 \mathrm{E}-03$ & 0.363083 \\
\hline kdep_grp & kdep_smw & kdep_lca & $1.00 \mathrm{E}-04$ & $1.40 \mathrm{E}-03$ & 4.32E-02 \\
\hline kdep_grp & kdep_vfvl & & $1.23 \mathrm{E}-02$ & $3.80 \mathrm{E}-06$ & $1.63 \mathrm{E}-02$ \\
\hline kdep_grp & kdep_vsuu & & $4.35 \mathrm{E}-03$ & $9.06 \mathrm{E}-05$ & $2.00 \mathrm{E}-02$ \\
\hline
\end{tabular}


Table A-1. Simulated parameter values estimated in the Death Valley regional groundwater flow system (DVRFS) v. 2.0 model.-Continued

[Parameter values and sensitivities displayed in scientific notation format. drn_grp, drain conductance, in square meters per day ( $\mathrm{m}^{2} / \mathrm{d}$ ); flt_grp, fault hydraulic characteristic of barrier, in 1/d; hk_grp, hydraulic conductivity, in m/d; kdep, depth decay, in 1/m; stor_grp, storage, unitless; sy_grp, specific yield, unitless; NA, value not assigned]

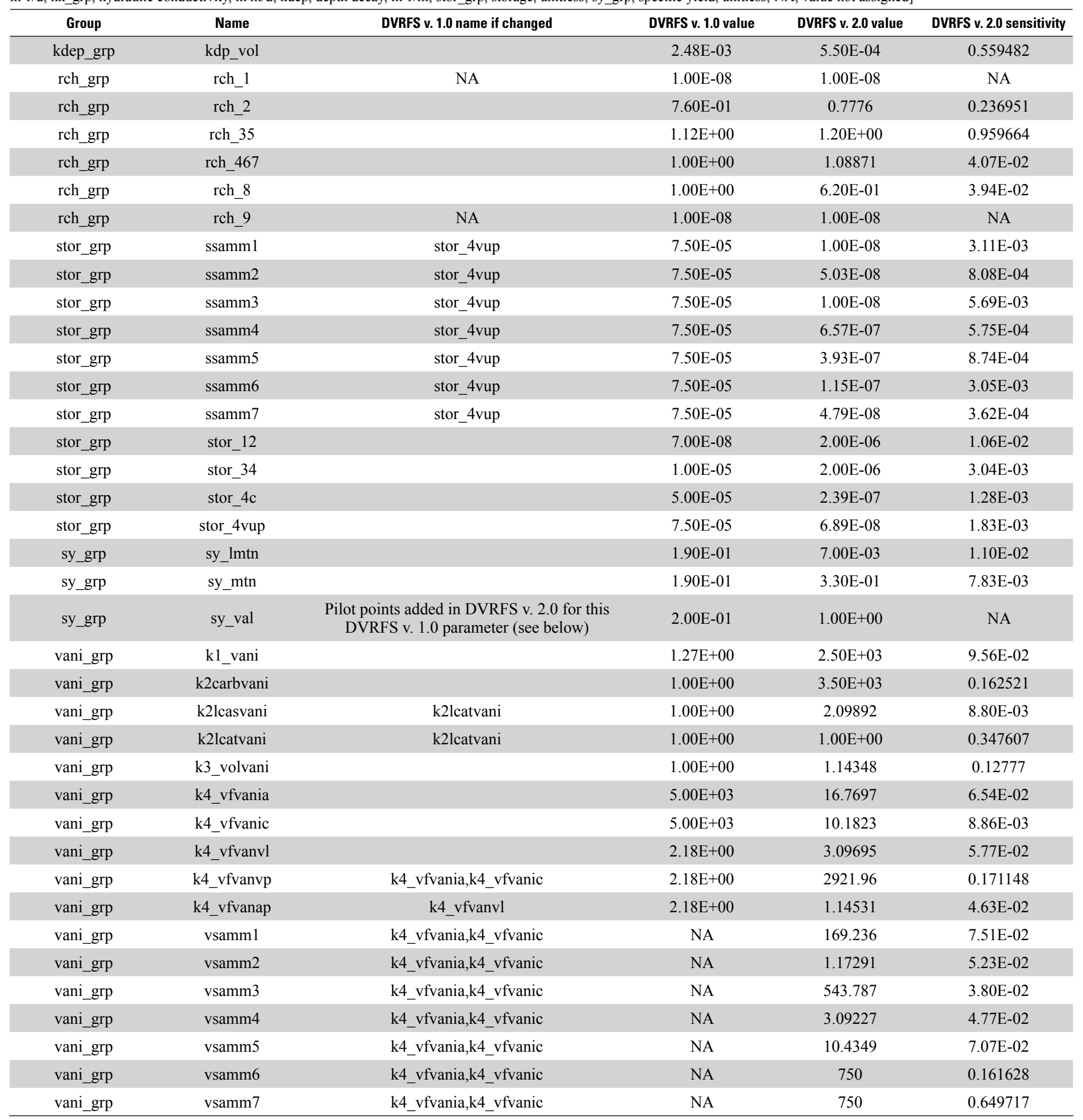


Table A-2. Simulated pilot points estimated in the Death Valley regional groundwater flow system (DVRFS) v. 2.0 model.

\begin{tabular}{|c|c|c|c|}
\hline Group & Name & DVRFS v. 2.0 value & $\begin{array}{c}\text { DVRFS v. } 2.0 \\
\text { sensitivity }\end{array}$ \\
\hline pps_grp & kvf_1 & $8.63 \mathrm{E}+00$ & $9.30 \mathrm{E}-04$ \\
\hline pps_grp & kvf_2 & $2.60 \mathrm{E}+01$ & $1.64 \mathrm{E}-03$ \\
\hline pps_grp & kvf_3 & $2.40 \mathrm{E}+01$ & $5.04 \mathrm{E}-04$ \\
\hline pps_grp & kvf_4 & $1.83 \mathrm{E}+00$ & 7.54E-04 \\
\hline pps_grp & kvf_5 & $4.12 \mathrm{E}-02$ & $1.80 \mathrm{E}-03$ \\
\hline pps_grp & kvf_6 & $1.59 \mathrm{E}+00$ & $2.55 \mathrm{E}-04$ \\
\hline pps_grp & kvf_7 & $8.96 \mathrm{E}+02$ & $1.00 \mathrm{E}-02$ \\
\hline pps_grp & kvf_8 & $5.24 \mathrm{E}-04$ & $1.09 \mathrm{E}-03$ \\
\hline pps_grp & kvf_9 & $8.25 \mathrm{E}-02$ & $1.26 \mathrm{E}-04$ \\
\hline pps_grp & kvf_10 & $1.41 \mathrm{E}+01$ & $2.18 \mathrm{E}-03$ \\
\hline pps_grp & kvf_11 & $5.62 \mathrm{E}+01$ & $8.42 \mathrm{E}-04$ \\
\hline pps_grp & kvf_12 & $4.18 \mathrm{E}-01$ & $1.02 \mathrm{E}-03$ \\
\hline pps_grp & kvf_13 & $1.54 \mathrm{E}-02$ & $4.45 \mathrm{E}-04$ \\
\hline pps_grp & kvf_14 & $1.32 \mathrm{E}+01$ & $1.17 \mathrm{E}-03$ \\
\hline pps_grp & kvf_15 & $1.76 \mathrm{E}-02$ & $1.09 \mathrm{E}-03$ \\
\hline pps_grp & kvf_16 & $5.75 \mathrm{E}-02$ & $1.79 \mathrm{E}-03$ \\
\hline pps_grp & kvf_17 & $4.28 \mathrm{E}+00$ & 7.64E-04 \\
\hline pps_grp & kvf_18 & $3.05 \mathrm{E}+02$ & $2.25 \mathrm{E}-03$ \\
\hline pps_grp & kvf_19 & $8.95 \mathrm{E}+00$ & $1.71 \mathrm{E}-03$ \\
\hline pps_grp & kvf_20 & $9.80 \mathrm{E}-02$ & $6.50 \mathrm{E}-04$ \\
\hline pps_grp & kvf_21 & 4.65E-01 & $9.06 \mathrm{E}-04$ \\
\hline pps_grp & kvf_22 & $2.14 \mathrm{E}+02$ & $6.01 \mathrm{E}-04$ \\
\hline pps_grp & kvf_23 & $2.99 \mathrm{E}-01$ & $3.46 \mathrm{E}-04$ \\
\hline pps_grp & kvf_24 & $1.30 \mathrm{E}+00$ & 2.07E-03 \\
\hline pps_grp & kvf_25 & $1.64 \mathrm{E}+00$ & $1.91 \mathrm{E}-03$ \\
\hline pps_grp & kvf_26 & $6.03 \mathrm{E}-01$ & $1.99 \mathrm{E}-04$ \\
\hline pps_grp & kvf_27 & $3.34-01$ & $7.25 \mathrm{E}-04$ \\
\hline pps_grp & kvf_28 & $6.27 \mathrm{E}-01$ & $6.09 \mathrm{E}-04$ \\
\hline pps_grp & kvf_29 & $1.52 \mathrm{E}+01$ & $3.56 \mathrm{E}-04$ \\
\hline pps_grp & kvf_30 & $2.60 \mathrm{E}-01$ & $1.75 \mathrm{E}-03$ \\
\hline pps_grp & kvf_31 & $7.74 \mathrm{E}-02$ & $1.58 \mathrm{E}-03$ \\
\hline pps_grp & kvf_32 & $8.65 \mathrm{E}-01$ & $2.49 \mathrm{E}-03$ \\
\hline pps_grp & kvf_33 & $1.33 \mathrm{E}+01$ & $1.07 \mathrm{E}-03$ \\
\hline pps_grp & kvf_34 & $3.00 \mathrm{E}+01$ & $1.13 \mathrm{E}-03$ \\
\hline pps_grp & kvf_35 & $8.96 \mathrm{E}+01$ & $1.18 \mathrm{E}-03$ \\
\hline pps_grp & kvf_36 & $1.21 \mathrm{E}-02$ & 4.19E-04 \\
\hline pps_grp & kvf_37 & $9.15 \mathrm{E}+00$ & $8.65 \mathrm{E}-04$ \\
\hline pps_grp & kvf_38 & $1.64 \mathrm{E}-01$ & $3.97 \mathrm{E}-04$ \\
\hline pps_grp & kvf_39 & $2.03 \mathrm{E}-01$ & $3.05 \mathrm{E}-03$ \\
\hline pps_grp & kvf_40 & $4.66 \mathrm{E}+01$ & $1.44 \mathrm{E}-03$ \\
\hline pps_grp & kvf_41 & $4.33 \mathrm{E}+01$ & $1.51 \mathrm{E}-04$ \\
\hline pps_grp & kvf_42 & $2.20 \mathrm{E}-01$ & $1.3 \mathrm{E}-03$ \\
\hline pps_grp & kvf_43 & $3.02 \mathrm{E}-01$ & $1.07 \mathrm{E}-03$ \\
\hline pps_grp & kvf_44 & $1.00 \mathrm{E}+01$ & $3.68 \mathrm{E}-04$ \\
\hline pps_grp & kvf_45 & $7.34 \mathrm{E}+01$ & $6.83 \mathrm{E}-04$ \\
\hline pps_grp & kvf_46 & $3.91 \mathrm{E}-01$ & $1.82 \mathrm{E}-03$ \\
\hline pps_grp & kvf_47 & $2.00 \mathrm{E}-02$ & $1.24 \mathrm{E}-03$ \\
\hline
\end{tabular}

Table A-2. Simulated pilot points estimated in the Death Valley regional groundwater flow system (DVRFS) v. 2.0 model. - Continued

\begin{tabular}{|c|c|c|c|}
\hline Group & Name & DVRFS v. 2.0 value & $\begin{array}{l}\text { DVRFS v. } 2.0 \\
\text { sensitivity }\end{array}$ \\
\hline pps_grp & kvf_48 & 4.10E-01 & $1.80 \mathrm{E}-04$ \\
\hline pps_grp & kvf_49 & $1.88 \mathrm{E}+01$ & $5.09 \mathrm{E}-04$ \\
\hline pps_grp & kvf_50 & $5.30 \mathrm{E}-01$ & $1.18 \mathrm{E}-03$ \\
\hline pps_grp & kvf_51 & $7.47 \mathrm{E}+01$ & $1.89 \mathrm{E}-03$ \\
\hline pps_grp & kvf_52 & $9.59 \mathrm{E}+02$ & $1.26 \mathrm{E}-03$ \\
\hline pps_grp & kvf 53 & $3.76 \mathrm{E}-01$ & $4.48 \mathrm{E}-04$ \\
\hline pps_grp & kvf_54 & $3.82 \mathrm{E}-01$ & $1.33 \mathrm{E}-03$ \\
\hline pps_grp & kvf_55 & $1.18 \mathrm{E}+00$ & $6.13 \mathrm{E}-04$ \\
\hline pps_grp & kvf_56 & $1.83 \mathrm{E}-02$ & $1.18 \mathrm{E}-03$ \\
\hline pps_grp & kvf_57 & $5.44 \mathrm{E}+01$ & $1.21 \mathrm{E}-03$ \\
\hline pps_grp & kvsu_u_1 & $7.59 \mathrm{E}-02$ & $2.75 \mathrm{E}-04$ \\
\hline pps_grp & kvsu_u_2 & 7.42E-03 & $6.91 \mathrm{E}-04$ \\
\hline pps_grp & kvsu_u_3 & $1.81 \mathrm{E}-01$ & $1.10 \mathrm{E}-03$ \\
\hline pps_grp & kvsu_u_4 & $3.36 \mathrm{E}-02$ & $1.35 \mathrm{E}-01$ \\
\hline pps_grp & kvsu_u_5 & $2.43 \mathrm{E}-02$ & $9.03 \mathrm{E}-04$ \\
\hline pps_grp & kvsu_u_6 & $3.59 \mathrm{E}-02$ & $3.13 \mathrm{E}-04$ \\
\hline pps_grp & kvsu_u_7 & 7.17E-01 & $4.53 \mathrm{E}-04$ \\
\hline pps_grp & kvsu_u_8 & $1.07 \mathrm{E}-02$ & $2.03 \mathrm{E}-03$ \\
\hline pps_grp & kvsu_u_9 & $3.37 \mathrm{E}-01$ & $1.70 \mathrm{E}-04$ \\
\hline pps_grp & kvsu_u_10 & $3.14 \mathrm{E}+00$ & $3.26 \mathrm{E}-04$ \\
\hline pps_grp & kvsu_u_11 & $1.91 \mathrm{E}-01$ & $3.50 \mathrm{E}-04$ \\
\hline pps_grp & kvsu_u_12 & $6.32 \mathrm{E}-02$ & $5.52 \mathrm{E}-04$ \\
\hline pps_grp & kvsu_u_13 & 3.37E-01 & $1.16 \mathrm{E}-03$ \\
\hline pps_grp & kvsu_u_14 & $9.29 \mathrm{E}-01$ & $1.00 \mathrm{E}-03$ \\
\hline pps_grp & kvsu_u_15 & $3.74 \mathrm{E}-02$ & $5.49 \mathrm{E}-04$ \\
\hline pps_grp & kvsu_u_16 & $3.56 \mathrm{E}-02$ & $3.48 \mathrm{E}-04$ \\
\hline pps_grp & kvsu_u_17 & 7.04E-01 & 7.81E-04 \\
\hline pps_grp & kvsu_u_18 & $1.08 \mathrm{E}-01$ & $6.73 \mathrm{E}-04$ \\
\hline pps_grp & kvsu_u_19 & $1.15 \mathrm{E}+00$ & $1.34 \mathrm{E}-01$ \\
\hline pps_grp & kvsu_u_20 & $4.85 \mathrm{E}-02$ & 5.91E-04 \\
\hline pps_grp & kvsu_u_21 & $6.15 \mathrm{E}+00$ & $6.42 \mathrm{E}-04$ \\
\hline pps_grp & kvsu_u_22 & $1.19 \mathrm{E}-01$ & $8.28 \mathrm{E}-04$ \\
\hline pps_grp & kvsu_u_23 & $2.08 \mathrm{E}+01$ & $1.25 \mathrm{E}-03$ \\
\hline pps_grp & kvsu_u_24 & $2.74 \mathrm{E}-02$ & 4.23E-04 \\
\hline pps_grp & kvsu_u_25 & $1.64 \mathrm{E}+00$ & $1.02 \mathrm{E}-03$ \\
\hline pps_grp & kvsu_u_26 & $3.78 \mathrm{E}-02$ & $6.88 \mathrm{E}-04$ \\
\hline pps_grp & kvsu_u_27 & $2.15 \mathrm{E}+00$ & $6.51 \mathrm{E}-04$ \\
\hline pps_grp & kvsu_u_28 & $4.29 \mathrm{E}-03$ & $1.17 \mathrm{E}-04$ \\
\hline pps_grp & kvsu_u_29 & $8.10 \mathrm{E}+00$ & $1.61 \mathrm{E}-03$ \\
\hline pps_grp & kvsu_u_30 & $2.30 \mathrm{E}-01$ & $7.70 \mathrm{E}-04$ \\
\hline pps_grp & kvsu_u_31 & $1.19 \mathrm{E}-02$ & $1.07 \mathrm{E}-03$ \\
\hline pps_grp & kvsu_u_32 & $1.55 \mathrm{E}+00$ & $1.57 \mathrm{E}-03$ \\
\hline pps_grp & kvsu_u_33 & $9.08 \mathrm{E}-01$ & $2.26 \mathrm{E}-03$ \\
\hline pps_grp & kvsu_u_34 & $4.15 \mathrm{E}-02$ & $2.50 \mathrm{E}-03$ \\
\hline pps_grp & kvsu_u_35 & $1.47 \mathrm{E}+01$ & $3.05 \mathrm{E}-03$ \\
\hline pps_grp & kvsu_u_36 & $8.83 \mathrm{E}-01$ & $1.95 \mathrm{E}-03$ \\
\hline pps_grp & kvsu_u_37 & $1.30 \mathrm{E}-01$ & $1.24 \mathrm{E}-03$ \\
\hline
\end{tabular}


Table A-2. Simulated pilot points estimated in the Death Valley regional groundwater flow system (DVRFS) v. 2.0 model. —Continued

\begin{tabular}{|c|c|c|c|}
\hline Group & Name & DVRFS v. 2.0 value & $\begin{array}{c}\text { DVRFS v. } 2.0 \\
\text { sensitivity }\end{array}$ \\
\hline pps_grp & kvsu_u_38 & $3.63 \mathrm{E}-02$ & $8.78 \mathrm{E}-04$ \\
\hline pps_grp & kvsu_u_39 & $2.42 \mathrm{E}-02$ & 4.64E-04 \\
\hline pps_grp & kvsu_u_40 & 2.03E-02 & $1.29 \mathrm{E}-03$ \\
\hline pps_grp & kvsu_u_41 & $2.92 \mathrm{E}+00$ & $1.09 \mathrm{E}-03$ \\
\hline pps_grp & kvsu_u_42 & $2.15 \mathrm{E}-03$ & $2.90 \mathrm{E}-04$ \\
\hline pps_grp & kvsu_u_43 & $3.14 \mathrm{E}-02$ & $1.10 \mathrm{E}-03$ \\
\hline pps_grp & kvsu_u_44 & $7.85 \mathrm{E}-01$ & $9.34 \mathrm{E}-04$ \\
\hline pps_grp & kvsu_u_45 & $2.69 \mathrm{E}+00$ & $6.53 \mathrm{E}-04$ \\
\hline pps_grp & kvsu_u_46 & $1.13 \mathrm{E}+01$ & $1.14 \mathrm{E}-03$ \\
\hline pps_grp & kvsu_u_47 & $1.28 \mathrm{E}+02$ & $6.37 \mathrm{E}-03$ \\
\hline pps_grp & kvsu_u_48 & $1.67 \mathrm{E}+00$ & 4.61E-04 \\
\hline pps_grp & kvsu_u_49 & $1.63 \mathrm{E}-01$ & $3.57 \mathrm{E}-04$ \\
\hline pps_grp & kvsu_u_50 & $1.57 \mathrm{E}+01$ & $9.14 \mathrm{E}-04$ \\
\hline pps_grp & kvsu_u_51 & $3.01 \mathrm{E}-02$ & 7.12E-04 \\
\hline pps_grp & kvsu_u_52 & $4.85 \mathrm{E}-02$ & $8.85 \mathrm{E}-04$ \\
\hline pps_grp & kvsu_u_53 & $1.12 \mathrm{E}-01$ & $1.16 \mathrm{E}-03$ \\
\hline pps_grp & kvsu_u_54 & $7.06 \mathrm{E}-03$ & $9.21 \mathrm{E}-04$ \\
\hline pps_grp & kvsu_u_55 & $1.02 \mathrm{E}-01$ & $4.20 \mathrm{E}-04$ \\
\hline pps_grp & kvsu_u_56 & $2.21 \mathrm{E}-03$ & $1.10 \mathrm{E}-03$ \\
\hline pps_grp & kvsu_u_57 & 4.97E-01 & $5.84 \mathrm{E}-04$ \\
\hline pps_grp & kvsu_1_1 & $1.73 \mathrm{E}-01$ & $6.16 \mathrm{E}-04$ \\
\hline pps_grp & kvsu_1_2 & 2.07E-02 & $3.38 \mathrm{E}-04$ \\
\hline pps_grp & kvsu_1_3 & $9.50 \mathrm{E}-04$ & $2.58 \mathrm{E}-04$ \\
\hline pps_grp & kvsu_1_4 & 2.84E-02 & 5.99E-04 \\
\hline pps_grp & kvsu_1_5 & $4.40 \mathrm{E}-03$ & $7.83 \mathrm{E}-04$ \\
\hline pps_grp & kvsu_1_6 & $2.46 \mathrm{E}-02$ & 4.99E-04 \\
\hline pps_grp & kvsu_1_7 & $2.41 \mathrm{E}-03$ & $1.54 \mathrm{E}-03$ \\
\hline pps_grp & kvsu_1_8 & $3.96 \mathrm{E}-03$ & $6.25 \mathrm{E}-04$ \\
\hline pps_grp & kvsu_1_9 & $6.32 \mathrm{E}-03$ & $5.39 \mathrm{E}-04$ \\
\hline pps_grp & kvsu_1_10 & $5.21 \mathrm{E}-02$ & $6.61 \mathrm{E}-04$ \\
\hline pps_grp & kvsu_1_11 & $2.88 \mathrm{E}-01$ & $1.03 \mathrm{E}-03$ \\
\hline pps_grp & kvsu_1_12 & $1.75 \mathrm{E}-03$ & $4.95 \mathrm{E}-03$ \\
\hline pps_grp & kvsu_1_13 & 4.64E-03 & $1.37 \mathrm{E}-03$ \\
\hline pps_grp & kvsu_1_14 & $1.02 \mathrm{E}-02$ & $6.25 \mathrm{E}-04$ \\
\hline pps_grp & kvsu_1_15 & $4.02 \mathrm{E}-03$ & $5.78 \mathrm{E}-04$ \\
\hline pps_grp & kvsu_1_16 & $5.71 \mathrm{E}-04$ & $7.98 \mathrm{E}-04$ \\
\hline pps_grp & kvsu_1_17 & 4.32E-03 & $7.90 \mathrm{E}-04$ \\
\hline pps_grp & kvsu_1_18 & $1.27 \mathrm{E}+00$ & $3.09 \mathrm{E}-04$ \\
\hline pps_grp & kvsu_1_19 & $5.46 \mathrm{E}-03$ & $4.65 \mathrm{E}-04$ \\
\hline pps_grp & kvsu_1_20 & $1.04 \mathrm{E}-03$ & 1.19E-03 \\
\hline pps_grp & kvsu_1_21 & $4.14 \mathrm{E}-03$ & 7.37E-04 \\
\hline pps_grp & kvsu_1_22 & $1.29 \mathrm{E}-01$ & $2.76 \mathrm{E}-04$ \\
\hline pps_grp & kvsu_1_23 & $4.05 \mathrm{E}-02$ & 7.48E-04 \\
\hline pps_grp & kvsu_1_24 & $1.64 \mathrm{E}-01$ & 8.69E-04 \\
\hline pps_grp & kvsu_1_25 & $7.68 \mathrm{E}-02$ & $7.26 \mathrm{E}-04$ \\
\hline pps_grp & kvsu_1_26 & $1.51 \mathrm{E}-02$ & $1.09 \mathrm{E}-03$ \\
\hline pps_grp & kvsu_1_27 & $6.71 \mathrm{E}-03$ & 4.63E-04 \\
\hline
\end{tabular}

Table A-2. Simulated pilot points estimated in the Death Valley regional groundwater flow system (DVRFS) v. 2.0 model. —Continued

\begin{tabular}{|c|c|c|c|}
\hline Group & Name & DVRFS v. 2.0 value & $\begin{array}{c}\text { DVRFS v. } 2.0 \\
\text { sensitivity }\end{array}$ \\
\hline pps_grp & kvsu_1_28 & $1.03 \mathrm{E}-01$ & $1.34 \mathrm{E}-01$ \\
\hline pps_grp & kvsu_1_29 & $1.36 \mathrm{E}-02$ & $1.61 \mathrm{E}-03$ \\
\hline pps_grp & kvsu_1_30 & $9.20 \mathrm{E}-03$ & $1.11 \mathrm{E}-03$ \\
\hline pps_grp & kvsu_1_31 & $3.67 \mathrm{E}+01$ & $2.12 \mathrm{E}-03$ \\
\hline pps_grp & kvsu_1_32 & $5.11 \mathrm{E}-01$ & $1.49 \mathrm{E}-03$ \\
\hline pps_grp & kvsu_1_33 & $2.56 \mathrm{E}-02$ & $1.09 \mathrm{E}-03$ \\
\hline pps_grp & kvsu_1_34 & $2.11 \mathrm{E}-01$ & $4.03 \mathrm{E}-04$ \\
\hline pps_grp & kvsu_1_35 & $8.61 \mathrm{E}-02$ & $4.08 \mathrm{E}-04$ \\
\hline pps_grp & kvsu_1_36 & $2.41 \mathrm{E}-03$ & $1.49 \mathrm{E}-03$ \\
\hline pps_grp & kvsu_1_37 & $7.82 \mathrm{E}-02$ & $1.26 \mathrm{E}-03$ \\
\hline pps_grp & kvsu_1_38 & $3.14 \mathrm{E}-02$ & 4.09E-04 \\
\hline pps_grp & kvsu_1_39 & $1.03 \mathrm{E}-02$ & $1.28 \mathrm{E}-03$ \\
\hline pps_grp & kvsu_1_40 & $1.32 \mathrm{E}+00$ & $3.68 \mathrm{E}-04$ \\
\hline pps_grp & kvsu_1_41 & $1.16 \mathrm{E}-02$ & $7.58 \mathrm{E}-04$ \\
\hline pps_grp & kvsu_1_42 & $2.61 \mathrm{E}-03$ & $8.30 \mathrm{E}-04$ \\
\hline pps_grp & kvsu_1_43 & $8.36 \mathrm{E}-03$ & $3.50 \mathrm{E}-04$ \\
\hline pps_grp & kvsu_1_44 & $3.08 \mathrm{E}-03$ & $1.08 \mathrm{E}-03$ \\
\hline pps_grp & kvsu_1_45 & $3.39 \mathrm{E}+00$ & 7.64E-04 \\
\hline pps_grp & kvsu_1_46 & $1.22 \mathrm{E}-03$ & $1.04 \mathrm{E}-03$ \\
\hline pps_grp & kvsu_1_47 & $3.83 \mathrm{E}-03$ & $6.63 \mathrm{E}-04$ \\
\hline pps_grp & kvsu_1_48 & $4.24 \mathrm{E}+00$ & 1.64E-03 \\
\hline pps_grp & kvsu_1_49 & $1.74 \mathrm{E}-02$ & $1.29 \mathrm{E}-03$ \\
\hline pps_grp & kvsu_1_50 & $3.90 \mathrm{E}-02$ & $6.41 \mathrm{E}-04$ \\
\hline pps_grp & kvsu_1_51 & $1.25 \mathrm{E}-01$ & $2.33 \mathrm{E}-03$ \\
\hline pps_grp & kvsu_1_52 & $1.96 \mathrm{E}-02$ & $3.06 \mathrm{E}-04$ \\
\hline pps_grp & kvsu_1_53 & $1.10 \mathrm{E}-01$ & $1.39 \mathrm{E}-03$ \\
\hline pps_grp & kvsu_1_54 & $6.31 \mathrm{E}-04$ & $8.76 \mathrm{E}-04$ \\
\hline pps_grp & kvsu_1_55 & $2.46 \mathrm{E}-02$ & $2.04 \mathrm{E}-03$ \\
\hline pps_grp & kvsu_1_56 & $1.00 \mathrm{E}-01$ & $8.00 \mathrm{E}-04$ \\
\hline pps_grp & kvsu_1_57 & $2.99 \mathrm{E}-02$ & $1.46 \mathrm{E}-03$ \\
\hline sy_grp & pp_ss1 & $3.00 \mathrm{E}-01$ & $1.03 \mathrm{E}-02$ \\
\hline sy_grp & pp_ss2 & $4.00 \mathrm{E}-02$ & $1.18 \mathrm{E}-03$ \\
\hline sy_grp & pp_ss3 & $5.05 \mathrm{E}-02$ & $1.62 \mathrm{E}-03$ \\
\hline sy_grp & pp_ss4 & $1.78 \mathrm{E}-01$ & $1.11 \mathrm{E}-03$ \\
\hline sy_grp & pp_ss5 & $3.00 \mathrm{E}-01$ & $7.93 \mathrm{E}-03$ \\
\hline sy_grp & pp_ss6 & $3.00 \mathrm{E}-01$ & $4.14 \mathrm{E}-03$ \\
\hline sy_grp & pp_ss7 & $6.15 \mathrm{E}-03$ & $5.79 \mathrm{E}-04$ \\
\hline sy_grp & pp_ss 8 & $1.00 \mathrm{E}-03$ & 2.97E-03 \\
\hline sy_grp & pp_ss9 & $1.02 \mathrm{E}-01$ & $1.17 \mathrm{E}-03$ \\
\hline sy_grp & pp_ss 10 & $1.00 \mathrm{E}-03$ & $4.87 \mathrm{E}-03$ \\
\hline sy_grp & pp_ss11 & $3.00 \mathrm{E}-01$ & $6.04 \mathrm{E}-03$ \\
\hline sy_grp & pp_ss12 & $3.00 \mathrm{E}-01$ & $2.06 \mathrm{E}-03$ \\
\hline sy_grp & pp_ss13 & $1.12 \mathrm{E}-01$ & $2.15 \mathrm{E}-03$ \\
\hline sy_grp & pp_ss 14 & $3.00 \mathrm{E}-01$ & 4.58E-03 \\
\hline sy_grp & pp_ss15 & $3.97 \mathrm{E}-02$ & $1.29 \mathrm{E}-04$ \\
\hline sy_grp & pp_ss 16 & $3.00 \mathrm{E}-01$ & $4.93 \mathrm{E}-03$ \\
\hline sy_grp & pp_ss17 & $3.00 \mathrm{E}-01$ & $1.16 \mathrm{E}-02$ \\
\hline
\end{tabular}


Table A-2. Simulated pilot points estimated in the Death Valley regional groundwater flow system (DVRFS) v. 2.0 model. —Continued

\begin{tabular}{|c|c|c|c|}
\hline Group & Name & DVRFS v. 2.0 value & $\begin{array}{l}\text { DVRFS v. } 2.0 \\
\text { sensitivity }\end{array}$ \\
\hline sy_grp & pp_ss18 & $1.79 \mathrm{E}-01$ & $5.92 \mathrm{E}-04$ \\
\hline sy_grp & pp_ss19 & $1.99 \mathrm{E}-01$ & $1.49 \mathrm{E}-03$ \\
\hline sy_grp & pp_ss20 & $3.00 \mathrm{E}-01$ & $4.01 \mathrm{E}-03$ \\
\hline sy_grp & pp_ss21 & $1.86 \mathrm{E}-01$ & $1.13 \mathrm{E}-03$ \\
\hline sy_grp & pp_ss22 & $3.00 \mathrm{E}-01$ & $5.69 \mathrm{E}-03$ \\
\hline sy_grp & pp_ss 23 & $3.00 \mathrm{E}-01$ & $5.53 \mathrm{E}-03$ \\
\hline sy_grp & pp_ss24 & $1.41 \mathrm{E}-01$ & $1.02 \mathrm{E}-03$ \\
\hline sy_grp & pp_ss 25 & $3.00 \mathrm{E}-01$ & $2.98 \mathrm{E}-03$ \\
\hline sy_grp & pp_ss26 & $3.00 \mathrm{E}-01$ & $3.01 \mathrm{E}-03$ \\
\hline sy_grp & pp_ss27 & 8.89E-02 & $2.22 \mathrm{E}-03$ \\
\hline sy_grp & pp_ss28 & $3.00 \mathrm{E}-01$ & $2.08 \mathrm{E}-03$ \\
\hline sy_grp & pp_ss29 & $3.00 \mathrm{E}-01$ & $1.89 \mathrm{E}-03$ \\
\hline sy_grp & pp_ss30 & $1.41 \mathrm{E}-01$ & $9.06 \mathrm{E}-03$ \\
\hline sy_grp & pp_ss31 & $3.00 \mathrm{E}-01$ & 4.94E-03 \\
\hline sy_grp & pp_ss32 & $3.00 \mathrm{E}-01$ & $4.29 \mathrm{E}-03$ \\
\hline sy_grp & pp_ss33 & $6.88 \mathrm{E}-02$ & $1.12 \mathrm{E}-03$ \\
\hline sy_grp & pp_ss34 & $3.00 \mathrm{E}-01$ & 4.44E-03 \\
\hline sy_grp & pp_ss35 & $2.15 \mathrm{E}-01$ & $6.55 \mathrm{E}-04$ \\
\hline sy_grp & pp_ss36 & 3.93E-02 & $2.18 \mathrm{E}-04$ \\
\hline sy_grp & pp_ss37 & $2.27 \mathrm{E}-02$ & $8.57 \mathrm{E}-03$ \\
\hline sy_grp & pp_ss38 & $3.00 \mathrm{E}-01$ & $4.51 \mathrm{E}-03$ \\
\hline sy_grp & pp_ss39 & $3.00 \mathrm{E}-01$ & $1.06 \mathrm{E}-03$ \\
\hline sy_grp & pp_ss40 & $3.00 \mathrm{E}-01$ & $8.60 \mathrm{E}-03$ \\
\hline sy_grp & pp_ss41 & $3.00 \mathrm{E}-01$ & $2.17 \mathrm{E}-01$ \\
\hline sy_grp & pp_ss 42 & $3.00 \mathrm{E}-01$ & $2.92 \mathrm{E}-03$ \\
\hline sy_grp & pp_ss43 & $2.72 \mathrm{E}-01$ & $1.25 \mathrm{E}-03$ \\
\hline sy_grp & pp_ss44 & $3.99 \mathrm{E}-02$ & $1.32 \mathrm{E}-03$ \\
\hline sy_grp & pp_ss45 & $2.08 \mathrm{E}-01$ & $1.13 \mathrm{E}-03$ \\
\hline sy_grp & pp_ss46 & $5.56 \mathrm{E}-02$ & $1.18 \mathrm{E}-03$ \\
\hline sy_grp & pp_ss47 & $3.00 \mathrm{E}-01$ & $3.68 \mathrm{E}-03$ \\
\hline sy_grp & pp_ss48 & $2.44 \mathrm{E}-01$ & $1.66 \mathrm{E}-03$ \\
\hline sy_grp & pp_ss49 & $2.39 \mathrm{E}-03$ & $1.97 \mathrm{E}-03$ \\
\hline sy_grp & pp_ss50 & 2.33E-01 & $3.10 \mathrm{E}-03$ \\
\hline sy_grp & pp_ss51 & $2.28 \mathrm{E}-01$ & $8.24 \mathrm{E}-02$ \\
\hline sy_grp & pp_ss52 & $3.00 \mathrm{E}-01$ & $1.38 \mathrm{E}-03$ \\
\hline sy_grp & pp_ss53 & $1.41 \mathrm{E}-01$ & $9.20 \mathrm{E}-04$ \\
\hline sy_grp & pp_ss54 & $6.86 \mathrm{E}-02$ & $7.96 \mathrm{E}-03$ \\
\hline sy_grp & pp_ss55 & $3.00 \mathrm{E}-01$ & $6.83 \mathrm{E}-03$ \\
\hline sy_grp & pp_ss56 & $3.00 \mathrm{E}-01$ & $3.17 \mathrm{E}-03$ \\
\hline sy_grp & pp_ss57 & $1.23 \mathrm{E}-01$ & $7.63 \mathrm{E}-04$ \\
\hline sy_grp & pp_ss58 & $3.00 \mathrm{E}-01$ & $1.30 \mathrm{E}-03$ \\
\hline sy_grp & pp_ss59 & $3.00 \mathrm{E}-01$ & $3.43 \mathrm{E}-03$ \\
\hline sy_grp & pp_ss60 & $3.00 \mathrm{E}-01$ & $4.75 \mathrm{E}-03$ \\
\hline sy_grp & pp_ss61 & 2.34E-02 & $8.03 \mathrm{E}-04$ \\
\hline sy_grp & pp_ss62 & $3.00 \mathrm{E}-01$ & $1.37 \mathrm{E}-03$ \\
\hline sy_grp & pp_ss63 & $2.59 \mathrm{E}-01$ & $2.45 \mathrm{E}-03$ \\
\hline sy_grp & pp_ss64 & $1.98 \mathrm{E}-01$ & 4.61E-04 \\
\hline
\end{tabular}

Table A-2. Simulated pilot points estimated in the Death Valley regional groundwater flow system (DVRFS) v. 2.0 model. - Continued

\begin{tabular}{|c|c|c|c|}
\hline Group & Name & DVRFS v. 2.0 value & $\begin{array}{l}\text { DVRFS v. } 2.0 \\
\text { sensitivity }\end{array}$ \\
\hline sy_grp & pp_ss65 & $3.00 \mathrm{E}-01$ & $1.08 \mathrm{E}-02$ \\
\hline sy_grp & pp_ss66 & $1.73 \mathrm{E}-01$ & $3.28 \mathrm{E}-03$ \\
\hline sy_grp & pp_ss67 & $2.74 \mathrm{E}-01$ & $1.15 \mathrm{E}-02$ \\
\hline sy_grp & pp_ss68 & 7.93E-02 & $1.98 \mathrm{E}-03$ \\
\hline sy_grp & pp_ss69 & $2.56 \mathrm{E}-01$ & $9.92 \mathrm{E}-04$ \\
\hline sy_grp & pp_ss70 & $3.00 \mathrm{E}-01$ & $1.73 \mathrm{E}-03$ \\
\hline sy_grp & pp_ss71 & $3.00 \mathrm{E}-01$ & $1.07 \mathrm{E}-02$ \\
\hline sy_grp & pp_ss72 & $1.89 \mathrm{E}-02$ & $1.42 \mathrm{E}-03$ \\
\hline sy_grp & pp_ss73 & 2.49E-01 & $9.00 \mathrm{E}-04$ \\
\hline sy_grp & pp_ss 74 & $3.00 \mathrm{E}-01$ & $1.14 \mathrm{E}-03$ \\
\hline sy_grp & pp_ss75 & $2.30 \mathrm{E}-03$ & $7.05 \mathrm{E}-04$ \\
\hline sy_grp & pp_ss76 & $1.72 \mathrm{E}-01$ & $6.04 \mathrm{E}-04$ \\
\hline sy_grp & pp_ss77 & $1.19 \mathrm{E}-01$ & $1.64 \mathrm{E}-03$ \\
\hline sy_grp & pp_ss78 & $2.44 \mathrm{E}-03$ & $1.94 \mathrm{E}-04$ \\
\hline sy_grp & pp_ss79 & $2.54 \mathrm{E}-02$ & $5.23 \mathrm{E}-04$ \\
\hline sy_grp & pp_ss 80 & $2.20 \mathrm{E}-02$ & $1.37 \mathrm{E}-03$ \\
\hline sy_grp & pp_ss81 & $3.37 \mathrm{E}-02$ & 8.14E-04 \\
\hline sy_grp & pp_ss82 & $3.00 \mathrm{E}-01$ & $3.66 \mathrm{E}-03$ \\
\hline sy_grp & pp_ss83 & $6.62 \mathrm{E}-02$ & $9.24 \mathrm{E}-04$ \\
\hline sy_grp & pp_ss84 & $2.82 \mathrm{E}-01$ & $6.21 \mathrm{E}-03$ \\
\hline sy_grp & pp_ss85 & $9.56 \mathrm{E}-02$ & $1.73 \mathrm{E}-03$ \\
\hline sy_grp & pp_ss 86 & $3.00 \mathrm{E}-01$ & $1.27 \mathrm{E}-02$ \\
\hline sy_grp & pp_ss87 & $3.00 \mathrm{E}-01$ & $5.89 \mathrm{E}-03$ \\
\hline sy_grp & pp_ss 88 & $3.00 \mathrm{E}-01$ & $4.89 \mathrm{E}-03$ \\
\hline sy_grp & pp_ss89 & $1.68 \mathrm{E}-01$ & $9.84 \mathrm{E}-03$ \\
\hline sy_grp & pp_ss 90 & $3.00 \mathrm{E}-01$ & 4.19E-03 \\
\hline sy_grp & pp_ss91 & $3.00 \mathrm{E}-01$ & $8.91 \mathrm{E}-03$ \\
\hline sy_grp & pp_ss92 & $3.00 \mathrm{E}-01$ & $6.12 \mathrm{E}-03$ \\
\hline sy_grp & pp_ss93 & $1.62 \mathrm{E}-01$ & $1.22 \mathrm{E}-03$ \\
\hline sy_grp & pp_ss94 & $3.00 \mathrm{E}-01$ & $1.39 \mathrm{E}-03$ \\
\hline sy_grp & pp_ss95 & $2.51 \mathrm{E}-01$ & $1.59 \mathrm{E}-03$ \\
\hline sy_grp & pp_ss96 & $1.14 \mathrm{E}-01$ & $3.31 \mathrm{E}-03$ \\
\hline sy_grp & pp_ss97 & $3.00 \mathrm{E}-01$ & $1.17 \mathrm{E}-02$ \\
\hline sy_grp & pp_ss 98 & $1.50 \mathrm{E}-01$ & $2.17 \mathrm{E}-02$ \\
\hline sy_grp & pp_ss99 & $3.00 \mathrm{E}-01$ & $6.06 \mathrm{E}-03$ \\
\hline sy_grp & pp_ss 100 & $1.08 \mathrm{E}-02$ & $1.09 \mathrm{E}-03$ \\
\hline sy_grp & pp_ss101 & $3.00 \mathrm{E}-01$ & $3.99 \mathrm{E}-03$ \\
\hline sy_grp & pp_ss102 & $1.27 \mathrm{E}-01$ & $1.35 \mathrm{E}-03$ \\
\hline sy_grp & pp_ss 103 & $3.00 \mathrm{E}-01$ & $2.08 \mathrm{E}-03$ \\
\hline sy_grp & pp_ss104 & $4.66 \mathrm{E}-03$ & $1.25 \mathrm{E}-03$ \\
\hline sy_grp & pp_ss105 & $3.01 \mathrm{E}-01$ & $4.37 \mathrm{E}-03$ \\
\hline sy_grp & pv_ss1 & $1.19 \mathrm{E}-01$ & $2.15 \mathrm{E}-01$ \\
\hline sy_grp & pv_ss2 & $5.62 \mathrm{E}-03$ & $1.24 \mathrm{E}-03$ \\
\hline sy_grp & pv_ss3 & $3.01 \mathrm{E}-01$ & $3.07 \mathrm{E}-03$ \\
\hline sy_grp & pv_ss4 & $1.60 \mathrm{E}-01$ & $2.16 \mathrm{E}-03$ \\
\hline sy_grp & pv_ss5 & $3.01 \mathrm{E}-01$ & $2.60 \mathrm{E}-04$ \\
\hline sy_grp & pv_ss6 & $3.01 \mathrm{E}-01$ & $3.57 \mathrm{E}-03$ \\
\hline
\end{tabular}


Table A-2. Simulated pilot points estimated in the Death Valley regional groundwater flow system (DVRFS) v. 2.0 model. —Continued

\begin{tabular}{|c|c|c|c|}
\hline Group & Name & DVRFS v. 2.0 value & $\begin{array}{l}\text { DVRFS v. } 2.0 \\
\text { sensitivity }\end{array}$ \\
\hline sy_grp & pv_ss7 & $6.92 \mathrm{E}-03$ & $9.89 \mathrm{E}-04$ \\
\hline sy_grp & pv_ss8 & $1.03 \mathrm{E}-03$ & $4.60 \mathrm{E}-03$ \\
\hline sy_grp & pv_ss9 & $3.01 \mathrm{E}-01$ & $3.18 \mathrm{E}-03$ \\
\hline sy_grp & pv_ss10 & $3.01 \mathrm{E}-01$ & 4.34E-03 \\
\hline sy_grp & pv_ss11 & $3.01 \mathrm{E}-01$ & $5.13 \mathrm{E}-03$ \\
\hline sy_grp & pv_ss12 & $1.29 \mathrm{E}-03$ & $7.35 \mathrm{E}-04$ \\
\hline sy_grp & pv_ss13 & $3.01 \mathrm{E}-01$ & $1.25 \mathrm{E}-03$ \\
\hline sy_grp & pv_ss14 & $3.01 \mathrm{E}-01$ & $3.01 \mathrm{E}-03$ \\
\hline sy_grp & pv_ss 15 & $3.01 \mathrm{E}-01$ & $5.56 \mathrm{E}-03$ \\
\hline sy_grp & pv_ss 16 & 7.74E-03 & 4.24E-04 \\
\hline sy_grp & pv_ss17 & $3.01 \mathrm{E}-01$ & 4.47E-03 \\
\hline sy_grp & pv_ss 18 & $6.31 \mathrm{E}-02$ & 4.61E-04 \\
\hline sy_grp & pv_ss19 & $3.01 \mathrm{E}-01$ & $3.15 \mathrm{E}-03$ \\
\hline sy_grp & pv_ss 20 & $2.60 \mathrm{E}-01$ & $5.47 \mathrm{E}-03$ \\
\hline sy_grp & pv_ss 21 & $3.01 \mathrm{E}-01$ & $2.48 \mathrm{E}-03$ \\
\hline sy_grp & pv_ss 22 & $3.01 \mathrm{E}-01$ & 4.37E-03 \\
\hline sy_grp & pv_ss 23 & 4.07E-02 & $2.18 \mathrm{E}-03$ \\
\hline sy_grp & pv_ss24 & $3.01 \mathrm{E}-01$ & $5.72 \mathrm{E}-03$ \\
\hline sy_grp & pv_ss 25 & $3.01 \mathrm{E}-01$ & $4.71 \mathrm{E}-03$ \\
\hline sy_grp & pv_ss 26 & $6.54 \mathrm{E}-02$ & $1.31 \mathrm{E}-03$ \\
\hline sy_grp & pv_ss27 & $6.23 \mathrm{E}-02$ & $8.38 \mathrm{E}-04$ \\
\hline sy_grp & pv_ss 28 & $3.01 \mathrm{E}-01$ & $2.46 \mathrm{E}-03$ \\
\hline sy_grp & pv_ss 29 & $3.01 \mathrm{E}-01$ & $1.38 \mathrm{E}-02$ \\
\hline sy_grp & pv_ss 30 & $3.01 \mathrm{E}-01$ & $6.00 \mathrm{E}-03$ \\
\hline sy_grp & pv_ss31 & $2.90 \mathrm{E}-01$ & $7.46 \mathrm{E}-03$ \\
\hline sy_grp & pv_ss32 & $1.00 \mathrm{E}-03$ & $1.29 \mathrm{E}-02$ \\
\hline sy_grp & pv_ss33 & $3.01 \mathrm{E}-01$ & $9.80 \mathrm{E}-03$ \\
\hline sy_grp & pv_ss34 & $3.01 \mathrm{E}-01$ & 4.44E-03 \\
\hline sy_grp & pv_ss35 & $3.01 \mathrm{E}-01$ & $2.89 \mathrm{E}-03$ \\
\hline sy_grp & pv_ss36 & $1.70 \mathrm{E}-02$ & $2.62 \mathrm{E}-03$ \\
\hline sy_grp & pv_ss37 & $7.58 \mathrm{E}-03$ & $2.05 \mathrm{E}-03$ \\
\hline sy_grp & pv_ss38 & $3.52 \mathrm{E}-03$ & $5.34 \mathrm{E}-04$ \\
\hline sy_grp & pv_ss39 & $2.74 \mathrm{E}-03$ & $1.58 \mathrm{E}-03$ \\
\hline sy_grp & pv_ss 40 & $2.08 \mathrm{E}-02$ & $8.19 \mathrm{E}-04$ \\
\hline sy_grp & pv_ss41 & $3.01 \mathrm{E}-01$ & $6.57 \mathrm{E}-03$ \\
\hline sy_grp & pv_ss42 & $2.53 \mathrm{E}-03$ & $3.20 \mathrm{E}-03$ \\
\hline sy_grp & pv_ss43 & $8.36 \mathrm{E}-03$ & $1.01 \mathrm{E}-03$ \\
\hline sy_grp & pv_ss44 & $5.15 \mathrm{E}-03$ & 7.77E-04 \\
\hline sy_grp & pv_ss45 & 3.33E-03 & $3.00 \mathrm{E}-03$ \\
\hline sy_grp & pv_ss46 & $9.32 \mathrm{E}-02$ & $1.65 \mathrm{E}-03$ \\
\hline sy_grp & pv_ss47 & 8.93E-03 & 7.77E-04 \\
\hline sy_grp & pv_ss48 & $3.65 \mathrm{E}-03$ & 7.87E-04 \\
\hline sy_grp & pv_ss49 & $1.00 \mathrm{E}-03$ & $1.50 \mathrm{E}-03$ \\
\hline sy_grp & pv_ss50 & $1.09 \mathrm{E}-02$ & $1.21 \mathrm{E}-03$ \\
\hline sy_grp & pv_ss51 & $4.86 \mathrm{E}-03$ & $2.06 \mathrm{E}-03$ \\
\hline sy_grp & pv_ss52 & $1.29 \mathrm{E}-03$ & $2.65 \mathrm{E}-03$ \\
\hline sy_grp & pv_ss53 & $9.22 \mathrm{E}-03$ & $5.86 \mathrm{E}-04$ \\
\hline
\end{tabular}

Table A-2. Simulated pilot points estimated in the Death Valley regional groundwater flow system (DVRFS) v. 2.0 model. - Continued

\begin{tabular}{|c|c|c|c|}
\hline Group & Name & DVRFS v. 2.0 value & $\begin{array}{l}\text { DVRFS v. } 2.0 \\
\text { sensitivity }\end{array}$ \\
\hline sy_grp & pv_ss54 & $3.01 \mathrm{E}-01$ & $2.33 \mathrm{E}-03$ \\
\hline sy_grp & pv_ss55 & $5.99 \mathrm{E}-02$ & $9.56 \mathrm{E}-04$ \\
\hline sy_grp & pv_ss56 & $3.20 \mathrm{E}-02$ & $9.54 \mathrm{E}-04$ \\
\hline sy_grp & pv_ss57 & $4.55 \mathrm{E}-03$ & $3.34 \mathrm{E}-03$ \\
\hline sy_grp & am_ss1 & $3.00 \mathrm{E}-01$ & $3.14 \mathrm{E}-03$ \\
\hline sy_grp & am_ss2 & $1.13 \mathrm{E}-01$ & $2.10 \mathrm{E}-03$ \\
\hline sy_grp & am_ss3 & $2.86 \mathrm{E}-01$ & $2.96 \mathrm{E}-03$ \\
\hline sy_grp & am_ss4 & $3.00 \mathrm{E}-01$ & $1.27 \mathrm{E}-02$ \\
\hline sy_grp & am_ss5 & $3.00 \mathrm{E}-01$ & 4.39E-03 \\
\hline sy_grp & am_ss6 & $1.04 \mathrm{E}-01$ & $5.48 \mathrm{E}-04$ \\
\hline sy_grp & am_ss7 & $3.00 \mathrm{E}-01$ & $8.64 \mathrm{E}-03$ \\
\hline sy_grp & am_ss8 & $3.00 \mathrm{E}-02$ & $7.12 \mathrm{E}-04$ \\
\hline sy_grp & am_ss9 & $3.00 \mathrm{E}-01$ & $1.84 \mathrm{E}-03$ \\
\hline sy_grp & am_ss10 & $1.45 \mathrm{E}-01$ & $2.08 \mathrm{E}-03$ \\
\hline sy_grp & am_ss11 & $3.00 \mathrm{E}-01$ & $1.48 \mathrm{E}-03$ \\
\hline sy_grp & am_ss 12 & $3.00 \mathrm{E}-01$ & $2.48 \mathrm{E}-03$ \\
\hline sy_grp & am_ss13 & $2.50 \mathrm{E}-01$ & $1.40 \mathrm{E}-03$ \\
\hline sy_grp & am_ss14 & $3.00 \mathrm{E}-01$ & $3.62 \mathrm{E}-03$ \\
\hline sy_grp & am_ss 15 & $3.00 \mathrm{E}-01$ & $1.09 \mathrm{E}-03$ \\
\hline sy_grp & am_ss16 & $3.00 \mathrm{E}-01$ & 4.54E-03 \\
\hline sy_grp & am_ss17 & $3.00 \mathrm{E}-01$ & $2.72 \mathrm{E}-03$ \\
\hline sy_grp & am_ss18 & $1.42 \mathrm{E}-01$ & $1.39 \mathrm{E}-03$ \\
\hline sy_grp & am_ss 19 & $3.00 \mathrm{E}-01$ & $5.31 \mathrm{E}-04$ \\
\hline sy_grp & am_ss 20 & $3.00 \mathrm{E}-01$ & $1.97 \mathrm{E}-03$ \\
\hline sy_grp & am_ss21 & $3.00 \mathrm{E}-01$ & $6.02 \mathrm{E}-03$ \\
\hline sy_grp & am_ss 22 & $3.28 \mathrm{E}-02$ & $2.16 \mathrm{E}-03$ \\
\hline sy_grp & am_ss 23 & $9.93 \mathrm{E}-02$ & $2.91 \mathrm{E}-03$ \\
\hline sy_grp & am_ss 24 & $3.00 \mathrm{E}-01$ & 4.03E-03 \\
\hline sy_grp & am_ss 25 & $3.00 \mathrm{E}-01$ & $1.14 \mathrm{E}-03$ \\
\hline sy_grp & am_ss 26 & $3.00 \mathrm{E}-01$ & $2.60 \mathrm{E}-03$ \\
\hline sy_grp & am_ss27 & $3.00 \mathrm{E}-01$ & 4.78E-03 \\
\hline sy_grp & am_ss 28 & $3.00 \mathrm{E}-01$ & $3.96 \mathrm{E}-03$ \\
\hline sy_grp & am_ss 29 & 7.64E-02 & $9.64 \mathrm{E}-04$ \\
\hline sy_grp & am_ss 30 & $3.00 \mathrm{E}-01$ & $2.22 \mathrm{E}-03$ \\
\hline sy_grp & am_ss31 & $3.00 \mathrm{E}-01$ & $5.29 \mathrm{E}-03$ \\
\hline sy_grp & am_ss 32 & $6.70 \mathrm{E}-02$ & $3.15 \mathrm{E}-03$ \\
\hline sy_grp & am_ss33 & $7.95 \mathrm{E}-02$ & 8.57E-04 \\
\hline sy_grp & am_ss34 & $4.85 \mathrm{E}-02$ & $1.38 \mathrm{E}-03$ \\
\hline sy_grp & am_ss35 & $3.00 \mathrm{E}-01$ & $1.51 \mathrm{E}-03$ \\
\hline sy_grp & am_ss 36 & $3.00 \mathrm{E}-01$ & $3.13 \mathrm{E}-03$ \\
\hline sy_grp & am_ss37 & $7.90 \mathrm{E}-02$ & $1.21 \mathrm{E}-03$ \\
\hline sy_grp & am_ss38 & $3.00 \mathrm{E}-01$ & $2.76 \mathrm{E}-03$ \\
\hline sy_grp & am_ss39 & $3.00 \mathrm{E}-01$ & $2.38 \mathrm{E}-03$ \\
\hline sy_grp & am_ss 40 & $2.74 \mathrm{E}-01$ & 4.67E-03 \\
\hline sy_grp & am_ss41 & $3.00 \mathrm{E}-01$ & $2.21 \mathrm{E}-03$ \\
\hline
\end{tabular}




\section{Appendix 2. Transmissivity prior-information used in DVRFS v. 2.0 and simulated results}

Table A-3. Transmissivity prior-information used in the Death Valley regional groundwater flow system (DVRFS) v. 2.0 model and simulated results.

\begin{tabular}{|c|c|c|}
\hline $\begin{array}{c}\text { Transmissivity } \\
\text { prior-information }\end{array}$ & $\begin{array}{c}\text { Observed value } \\
\text { (square meters per day) }\end{array}$ & $\begin{array}{c}\text { Simulated value } \\
\text { (square meters per day) }\end{array}$ \\
\hline TOBS_FL14 & 44 & 17.17 \\
\hline TOBS_4922DCC & 300 & 310.79 \\
\hline TOBS_AW & 270 & 310.79 \\
\hline TOBS_DW & 200 & 310.79 \\
\hline TOBS_NC9SX & 680 & 82.79 \\
\hline TOBS_FCTW & 6,000 & 11.60 \\
\hline TOBS_W3WW & 340 & 17.93 \\
\hline TOBS_TWA & 151.5 & 17.17 \\
\hline TOBS_WW5A & 30 & 17.17 \\
\hline TOBS_WW5B & 90 & 17.17 \\
\hline TOBS_WW5C & 32 & 17.17 \\
\hline TOBS_SM2 & 1,300 & 30.22 \\
\hline TOBS_SM3 & 810 & 30.22 \\
\hline TOBS_SM4 & 1,800 & 30.22 \\
\hline TOBS_SM5 & 560 & 32.28 \\
\hline TOBS_SM10 & 57 & 4.12 \\
\hline TOBS_18S5107 & 2,500 & 30.22 \\
\hline TOBS_WW3 & 16 & 5.14 \\
\hline TOBS_UE25C11 & 270 & 8.85 \\
\hline TOBS_UE25C12 & 5.3 & 8.85 \\
\hline TOBS_UE25C13 & 4 & 8.85 \\
\hline TOBS_UE25C14 & 360 & 8.85 \\
\hline TOBS_UE25C15 & 780 & 52.90 \\
\hline TOBS_UE25C16 & 730 & 1.35 \\
\hline TOBS_UE25C17 & 1,600 & 8.85 \\
\hline TOBS_UE25C18 & 1,800 & 8.85 \\
\hline TOBS_UE25C19 & 1,600 & 52.90 \\
\hline TOB_UE25C11 & 800 & 1.35 \\
\hline TOB_UE25C12 & 90 & 52.90 \\
\hline TOB_UE25C13 & 1,800 & 52.90 \\
\hline TOB_UE25C14 & 30 & 3.29 \\
\hline TOBS_UE25C21 & 170 & 8.85 \\
\hline TOBS_UE25C22 & 381 & 52.90 \\
\hline TOBS_UE25C23 & 2,100 & 8.85 \\
\hline TOBS_UE25C24 & 40 & 3.29 \\
\hline TOBS_UE25C25 & 100 & 52.90 \\
\hline TOBS_UE25C26 & 1,300 & 52.90 \\
\hline TOBS_UE25C31 & 28 & 8.85 \\
\hline TOBS_UE25C32 & 45 & 52.90 \\
\hline TOBS_UE25C33 & 3,200 & 8.85 \\
\hline TOBS_UE25C34 & 30 & 3.29 \\
\hline TOBS_UE25ONC & 970 & 3.58 \\
\hline
\end{tabular}

Table A-3. Transmissivity prior-information used in the Death Valley regional groundwater flow system (DVRFS) v. 2.0 model and simulated results.-Continued

\begin{tabular}{|c|c|c|}
\hline $\begin{array}{c}\text { Transmissivity } \\
\text { prior-information }\end{array}$ & $\begin{array}{c}\text { Observed value } \\
\text { (square meters per day) }\end{array}$ & $\begin{array}{c}\text { Simulated value } \\
\text { (square meters per day) }\end{array}$ \\
\hline TOBS_UE25WT3 & 2,600 & 0.09 \\
\hline TOBS_USWWT10 & 1,400 & $50,690.97$ \\
\hline TOB_UE25WT12 & 5.8 & 0.04 \\
\hline TOB_UE25WT14 & 1,300 & 12.82 \\
\hline TOBS_USWH1 & 150 & 3.09 \\
\hline TOBS_USWG2 & 9.4 & 26.09 \\
\hline TOBS_USWH41 & 12 & 3.67 \\
\hline TOBS_USWH42 & 19 & 3.67 \\
\hline TOBS_USWH43 & 7 & 3.67 \\
\hline TOBS_USWH44 & 1 & 3.67 \\
\hline TOBS_USWH45 & 56 & 43.57 \\
\hline TOBS_USWH46 & 19 & 43.57 \\
\hline TOBS_USWH47 & 9 & 2.97 \\
\hline TOBS_USWH48 & 42 & 2.97 \\
\hline TOBS_USWH49 & 13 & 2.97 \\
\hline TOB_USWH410 & 1 & 2.97 \\
\hline TOB_USWH411 & 200 & 3.67 \\
\hline TOB_USWH412 & 3,200 & 3.67 \\
\hline TOB_USWH413 & 660 & 3.67 \\
\hline TOB_USWG4 & 622 & 3.13 \\
\hline TOBS_USWH5 & 36 & 2.64 \\
\hline TOBS_USWH61 & 10 & 61.55 \\
\hline TOBS_USWH62 & 30 & 61.55 \\
\hline TOBS_USWH63 & 290 & 61.55 \\
\hline TOBS_USWH64 & 150 & 1.68 \\
\hline TOBS_USWH65 & 480 & 61.55 \\
\hline TOBS_UE25P12 & 24 & 2.41 \\
\hline TOBS_UE25P13 & 1.5 & 43.22 \\
\hline TOBS_UE25P14 & 0.5 & 43.22 \\
\hline TOBS_UE25P15 & 24 & 2.41 \\
\hline TOBS_UE25P16 & 2 & 1.86 \\
\hline TOB_NCEWDP3D & 230 & 2.41 \\
\hline TOB_NCEWDP1S & 1,000 & 0.03 \\
\hline TO_NCEWDP9SX & 1,020 & $8,899.94$ \\
\hline TOBS_UE18R & 290 & 56.29 \\
\hline TOBS_UE19B1 & 696 & 253.28 \\
\hline TOBS_UE19C & 149 & 368.40 \\
\hline TOBS_UE19D & 248 & 96.62 \\
\hline TOBS_UE19E & 104 & 242.73 \\
\hline TOBS_UE19FS & 137 & 12.10 \\
\hline TOBS_UE19GS & 373 & 312.45 \\
\hline TOBS_UE19H & 1,740 & 240.15 \\
\hline
\end{tabular}


Table A-3. Transmissivity prior-information used in the Death Valley regional groundwater flow system (DVRFS) v. 2.0 model and simulated results.-Continued

\begin{tabular}{|c|c|c|}
\hline $\begin{array}{c}\text { Transmissivity } \\
\text { prior-information }\end{array}$ & $\begin{array}{c}\text { Observed value } \\
\text { (square meters per day) }\end{array}$ & $\begin{array}{c}\text { Simulated value } \\
\text { (square meters per day) }\end{array}$ \\
\hline TOBS_UE19I & 17.4 & 188.72 \\
\hline TOBS_U20A2WW & 224 & 0.69 \\
\hline TOBS_UE20D & 547 & 37.91 \\
\hline TOBS_UE20E1 & 103 & 0.74 \\
\hline TOBS_UE20H & 130 & 92.44 \\
\hline TOBS_UE20J & 733 & 0.18 \\
\hline TOBS_ER2061 & 240 & 0.61 \\
\hline TOBS_ER2062 & 150 & 0.61 \\
\hline TOBSER2063 & 47 & 0.61 \\
\hline TOBS_UE25A1 & 344 & 49.10 \\
\hline TOBS_PM3 & 6.5 & 0.40 \\
\hline TOBS_USWH4 & 23 & 3.74 \\
\hline TOBS_USWH3 & 1 & 5.03 \\
\hline TOBS_UE25P11 & 2 & 0.92 \\
\hline TOBS_TW8 & 5 & 0.45 \\
\hline TOBS_W1WW & 3 & 0.99 \\
\hline TOBS_U1535 & 1 & 30.43 \\
\hline TOBS_ATSTH1 & 12,000 & $8,863.77$ \\
\hline TOBS_ATSTH3 & 13,600 & $8,863.77$ \\
\hline TOBS_ATSSH1 & 13,600 & $8,863.77$ \\
\hline TOBS_FSSW & 330 & $48,262.00$ \\
\hline TOBS_NCAPDR1 & 42 & $1,094.55$ \\
\hline TOBS_UE25P17 & 110 & 1.39 \\
\hline TOBS_UE7NS & 0.89 & $2,054.53$ \\
\hline TOBS_TW2 & 4.9 & 406.24 \\
\hline TOBS_ER121 & 35 & 20.84 \\
\hline TOBS_ARMY1 & 484 & $196,304.68$ \\
\hline TOBS_TW10 & 248.4 & 120.41 \\
\hline TOBS_TW4 & 136.62 & 307.38 \\
\hline TOBS_TW3 & 47 & 285.77 \\
\hline TOBS_TW1 & 44 & 56.57 \\
\hline TOBS_U3CN5 & 30 & $18,854.65$ \\
\hline
\end{tabular}




\section{Appendix 3. Instructions for converting a HUF-based model to a BCF-based model}

Many third-party pre- and post-processors for MODFLOW do not support the Hydrogeologic-Unit Flow (HUF) (Anderman and Hill, 2000) or HUF2 (Anderman and Hill, 2003) packages. Because of this, it became necessary to develop a methodology to convert a HUF-based model to a Block-Center Flow (BCF) package-based model. The following method uses the HUFPrint utility (Banta and Provost, 2008) to convert the existing HUF-based flow model to a BCF-based flow model:

1. Use HUFPrint print_flag HK to produce horizontal hydraulic conductivity (HK) for each model layer.

2. For confined layers, multiply by the layer thickness to get the transmissivity arrays needed by BCF.

3. Use HUFPrint print_flag CV to produce the conductances between a cell and a cell below. These values are multiplied by the cell area and need to be divided by that value to produce the branch conductances (CV). 
For additional information, contact:

Director, Nevada Water Science Center U.S. Geological Survey

2730 N. Deer Run Rd.

Carson City, NV 89701

http://nevada.usgs.gov/ 

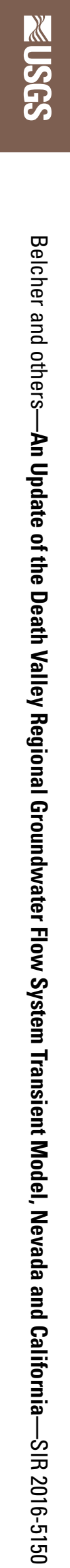